\title{
Gestão, mediação e uso da informação
}

\author{
Marta Valentim \\ (org.)
}

VALENTIM, M. org. Gestão, mediação e uso da informação [online]. São Paulo: Editora UNESP; São Paulo: Cultura Acadêmica, 2010. 390 p. ISBN 978-85-7983-117-1. Available from SciELO Books <http://books.scielo.org>.

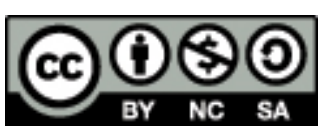

All the contents of this work, except where otherwise noted, is licensed under a Creative Commons Attribution-Non Commercial-ShareAlike 3.0 Unported.

Todo o conteúdo deste trabalho, exceto quando houver ressalva, é publicado sob a licença Creative Commons Atribuição Uso Não Comercial - Partilha nos Mesmos Termos 3.0 Não adaptada.

Todo el contenido de esta obra, excepto donde se indique lo contrario, está bajo licencia de la licencia Creative Commons Reconocimento-NoComercial-CompartirIgual 3.0 Unported. 


\section{GESTÃO, \\ MEDIAÇÃO \\ E USO DA \\ INFORMAÇÃO}

MARTA VALENTIM

(ORG.) 


\section{GESTÃo, \\ MEDIAÇÃO E USO \\ DA INFORMAÇÃO}


CONSELHO EDITORIAL ACADÊMICO

Responsável pela publicação desta obra

\author{
Edberto Ferneda
}

Helen de Castro Silva Casarin

João Batista Ernesto de Moraes

José Augusto Chaves Guimarães

Mariângela Spotti Lopes Fujita

Marta Ligia Pomim Valentim 
MARTA VALENTIM (ORG.)

\section{GESTÃO, \\ MEDIAÇÃO E USO DA INFORMAÇÃO}

CULTURA $\frac{\text { ACADÊMICA }}{\mathcal{E} \text { ditona }}$ 
(C) 2010 Editora UNESP

\section{Cultura Acadêmica}

Praça da Sé, 108

01001-900 - São Paulo - SP

Tel.: (0xx11) 3242-7171

Fax: (0xx11) 3242-7172

www.editoraunesp.com.br

feu@editora.unesp.br

CIP - Brasil. Catalogação na fonte

Sindicato Nacional dos Editores de Livros, RJ

G333

Gestão, mediação e uso da informação / Marta Valentim (org.). - São

Paulo : Cultura Acadêmica, 2010.

Inclui bibliografia

ISBN 978-85-7983-117-1

1. Gestão do conhecimento. 2. Tecnologia da informação. 3. Gerenciamento de recursos da informação. I. Valentim, Marta Ligia Pomim.

$11-0140$.

CDD: 658.4038

CDU: 005.94

Este livro é publicado pelo Programa de Publicações Digitais da Pró-Reitoria de Pós-Graduação da Universidade Estadual Paulista "Júlio de Mesquita Filho" (UNESP)

Editora afiliada:
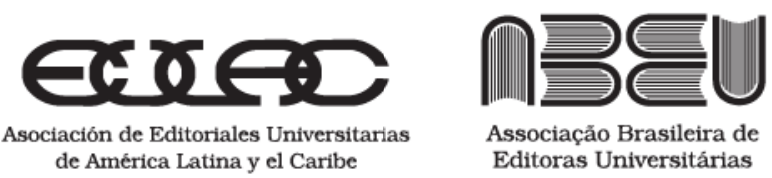


\section{SUMÁRIO}

Apresentação 9

1 Gestão, mediação e uso da informação 13 Bárbara Fadel, Carlos Cândido de Almeida, Helen de Castro Silva Casarin, Marta Lígia Pomim Valentim, Oswaldo Francisco de Almeida Júnior, Regina Célia Baptista Belluzzo

2 Gestão do conhecimento nas organizações: perspectivas de uso da Metodologia Sistêmica Soft (Soft Systems Methodology) 33

Cássia Regina Bassan de Moraes, Bárbara Fadel

3 Estratégias de preservação digital 59 José Carlos Abbud Grácio, Bárbara Fadel

4 Mediação oral literária: algumas palavras 85 Sueli Bortolin, Oswaldo Francisco de Almeida Júnior

5 Contribuições teóricas e metodológicas da sociologia do conhecimento para estudos de produção de conhecimento em contextos empresariais 105 Luana Maia Woida 
6 Modelo de comportamento informacional de usuários: uma abordagem teórica 127 Rodrigo Octávio Beton Matta

7 Tecnologias de informação e comunicação para gestão da informação e do conhecimento: proposta de uma estrutura tecnológica aplicada aos portais corporativos 143 Letícia Gorri Molina

8 A inter-relação entre o profissional da informação e o profissional contabilista: necessidades informacionais Marinês Santana Justo Smith, Bárbara Fadel

9 Leitura, informação e conhecimento: notas sobre a leitura de jornal 191

Tamara de Souza Brandão Guaraldo, Oswaldo Francisco de Almeida Júnior

10 Cultura organizacional e as interferências nos fluxos informacionais (IFI) 211

Regis Garcia, Bárbara Fadel

11 Informação e conhecimento no contexto de ambientes organizacionais 235

Luciane de Fátima Beckman Cavalcante, Marta Lígia Pomim Valentim

12 Competência em informação e sua avaliação 255 André Luís Onório Coneglian, Camila Araújo dos Santos, Helen de Castro Silva Casarin

13 Gestão da informação e governança corporativa em empresas de capital aberto 277 Elaine Cristina Lopes, Marta Lígia Pomim Valentim

14 A formação do bibliotecário e a competência informacional: um olhar através das competências 301 Marta Leandro da Mata, Helen de Castro Silva Casarin 
15 Informação e conhecimento como alicerces para a gestão estratégica empresarial: um enfoque nos fluxos e fontes de informação 319

Cíntia Gomes Pacheco, Marta Lígia Pomim Valentim

$16 \mathrm{O}$ comportamento informacional de advogados: uma revisão da literatura 343

Marli Vítor da Silva, Helen de Castro Silva Casarin

17 A relação entre a informação orgânica e a gestão documental 361

Mariana Lousada, Marta Lígia Pomim Valentim

Sobre os autores $\quad 385$ 



\section{APRESENTAÇÃo}

O livro Gestão, mediação e uso da informação vai ao encontro dos estudos teóricos e metodológicos de objetos e fenômenos que envolvem gestão, mediação, uso e apropriação da informação em distintos ambientes. Assim, o Capítulo 1 discorre de forma sintética sobre esses elementos que alicerçam a Linha de Pesquisa "Gestão, mediação e uso da informação”, no Programa de Pós-Graduação em Ciência da Informação.

O Capítulo 2 apresenta algumas considerações sobre a aplicação da metodologia Soft Systems Methodology (SSM) para a articulação de problemas pouco estruturados, voltada à gestão do conhecimento em ambientes organizacionais.

Discutir sobre as estratégias de preservação da informação digital é o escopo do Capítulo 3. Destaca a importância de as instituições pensarem a preservação digital de forma ampla, bem como da necessidade da formulação de políticas específicas para esse novo contexto social-tecnológico.

O Capítulo 4 discute a mediação a partir da palavra e destaca a proposta da Mediação Oral Literária (MOL). Sustenta que o mediador de leitura deve avaliar o local onde desenvolverá a mediação, afirmando que a preocupação principal deve ser a construção de uma ambiência para a narrativa, levando em conta que o imagi- 
nário e o prazer estético são fundamentais aos indivíduos em qualquer faixa etária.

Apresentando uma breve explanação sobre a origem e as bases de constituição da sociologia do conhecimento, bem como um dos métodos aplicados a essa área, o Capítulo 5 discute a contribuição da sociologia do conhecimento como base teórica orientadora para interpretar a realidade organizacional.

O Capítulo 6 trata do papel da ciência da informação e dos estudos desenvolvidos em relação aos usuários de informação, traz uma visão geral da importância de se estudar os usuários e seus comportamentos informacionais e a possibilidade de uso de conhecimentos sobre o comportamento humano no desenvolvimento de pesquisas sobre esse tema.

Um problema enfrentado pelas organizações atuais refere-se a gerenciamento, organização, tratamento, disseminação e uso da informação organizacional. Os conteúdos informacionais produzidos pelas organizações têm aumentado em quantidade e complexidade, além das informações produzidas no ambiente externo à organização, e que são disponibilizadas em maior quantidade e facilidade de acesso. O Capítulo 7 discorre, assim, sobre a falta de estruturação e uso de sistemas informáticos eficientes, que auxiliem no registro e acesso a essas informações, bem como apresenta um modelo de estrutura para sistemas de informação e conhecimento.

O Capítulo 8 discute as contribuições do campo científico da ciência da informação no tocante aos usuários e suas necessidades de informações aplicadas à área contábil financeira. Apresenta discussões sobre habilidades e competências do profissional da informação no âmbito da ciência da informação, discorre sobre o papel do contabilista como gestor da informação contábil e, por fim, apresenta reflexões da contribuição do profissional da informação ao profissional contabilista.

O Capítulo 9 apresenta uma breve reflexão sobre a leitura como uma experiência concreta, que comporta práticas, saberes, leitores, sujeitos na vida cotidiana, e também dados, informações 
que descrevem essa experiência, escolhendo como tema dessa discussão a leitura do jornal diário.

A partir do diagnóstico da cultura, do planejamento e da implantação de ações de interferências nos fluxos informacionais, o Capítulo 10 apresenta argumentos que enfatizam a importância da cultura organizacional como elemento norteador do comportamento dos indivíduos em espaços organizacionais.

O Capítulo 11 enfoca o ambiente organizacional explorando a relevância da informação e do conhecimento nesse contexto, discutindo também as questões inerentes ao comportamento informacional.

Discutindo o conceito e as diferentes traduções da expressão information literacy, o Capítulo 12 resgata as diversas traduções ou expressões que representam o conceito de competência em informação.

O Capítulo 13 aborda a temática "governança corporativa" enfocando o conceito de transparência na prestação de informações. Destaca que as estruturas de gestão da informação interna e externa são fundamentais, porque as empresas geram grande quantidade de informações que, por sua vez, são utilizadas por um número significativo de usuários.

Considerando a inclusão da competência informacional como um dos conteúdos programáticos importantes para a formação do bibliotecário, o Capítulo 14 apresenta a importância dessa discussão junto às lideranças formadoras, visto que a formação bibliotecária deveria certificar conhecimentos, habilidades, destrezas e atitudes relacionados a esses saberes e fazeres.

O Capítulo 15 apresenta algumas reflexões acerca do uso da informação e do conhecimento no âmbito empresarial. Destaca os fluxos internos e externos de informação presentes nesse ambiente, além das fontes de informação existentes que podem ser consultadas pelas pessoas atuantes nessas organizações, de forma que desenvolvam suas atividades de forma mais segura e tomem decisões de maneira mais assertiva.

Analisando alguns estudos desenvolvidos sobre o comportamento informacional de advogados, o Capítulo 16 apresenta um panorama geral de investigação realizado nessa área até o momento. 
O Capítulo 17 apresenta uma discussão referente ao conceito de informação orgânica, bem como identifica as relações desse tipo de informação com a gestão documental, visto que se trata de um campo teórico ainda em formação e propício a intensas discussões e novas aproximações.

Os capítulos do livro são relacionados aos diversos projetos de pesquisa desenvolvidos tanto em âmbito de doutorado quanto em de mestrado e refletem as competências em pesquisa dos autores envolvidos.

Marta L. P. Valentim

Organizadora 


\title{
1 \\ GESTÃo, MEDIAÇÃo E USO DA INFORMAÇÃo
}

\author{
Bárbara Fadel \\ Carlos Cândido de Almeida \\ Helen de Castro Silva Casarin \\ Marta Lígia Pomim Valentim \\ Oswaldo Francisco de Almeida Júnior \\ Regina Célia Baptista Belluzzo
}

\section{Introdução}

A linha de pesquisa "Gestão, Mediação e Uso da Informação" se constituiu a partir de temáticas imbricadas e é sustentada por abordagens teóricas e metodológicas que consolidam o saber/conhecer e o saber/fazer nesse âmbito.

Os estudos sobre a informação, o conhecimento e a inteligência em contextos organizacionais são alicerçados na gestão da informação e do conhecimento e são essenciais para a constituição da memória organizacional, de políticas de informação, de ambientes e fluxos informacionais compreendidos de forma ampla.

As pesquisas voltadas para a aprendizagem informacional contemplam as questões culturais, comportamentais e as competências que envolvem produtores, intermediários e usuários de informação, e, por isso mesmo, proporcionam à linha a possibilidade de discutir a dinâmica informacional e os processos cognitivos subjacentes envolvidos desde as necessidades, buscas e usos de informação.

Nesse âmbito, os estudos relacionados às competências em informação preocupam-se fundamentalmente com o desenvolvimento do usuário, no que tange tanto a interação com diferentes 
recursos informacionais quanto a aprendizagem e autonomia para apropriar-se da informação para gerar conhecimento.

A mediação da informação se constitui em uma das problemáticas investigadas na linha de pesquisa, enfocando as formas de mediação, a recepção e a apropriação da informação em diferentes contextos, de forma a refletir o papel do profissional da informação e compreender o usuário em sua complexidade. No âmbito da apropriação da informação os estudos pretendem também aprofundar os conhecimentos acerca da ação interpretativa do usuário, pois a informação pode ser determinada pelas relações sígnicas construídas a partir da experiência anterior do usuário.

O objeto da linha de pesquisa refere-se aos processos de análise e desenvolvimento de estruturas e modelos de gestão, mediação, uso e apropriação da informação em ambientes informacionais de diferentes contextos, como elementos inseridos no escopo do campo científico da ciência da informação.

\section{Gestão da informação e do conhecimento}

As organizações são núcleos sociais, uma vez que elas congregam pessoas de uma determinada comunidade, por isso o desenvolvimento de uma sociedade recebe grande influência das organizações. Assim, as organizações são núcleos sociais que tanto influenciam o meio em que estão inseridas quando recebem influência do meio influenciado. As organizações são uma forma de sociabilidade produzida, transmitida, partilhada e renovada (Sainsaulieu \& Kirschner, 2006).

A informação é insumo para qualquer fazer, seja no âmbito acadêmico, seja no âmbito empresarial. A geração de "novo" conhecimento somente é possível quando a informação é apropriada pelo indivíduo, por meio do estabelecimento de relações cognitivas. Compreender que esses elementos constituem a base para diferentes ações -, tomada de decisão, planejamento, estratégias de ação etc. que resultarão no desenvolvimento de uma organização, é o primei- 
ro passo para desenvolver a percepção correta da relação e interdependência existente.

Os ambientes organizacionais complexos são apoiados por informação e conhecimento, por isso mesmo destacamos o papel desses insumos para amenizar ou reduzir a incerteza ou, ao contrário, alterar a estabilidade do conhecer e provocar mais dúvida e insegurança no indivíduo, cujos processos cognitivos são realizados na tentativa de responder às necessidades informacionais.

Defendemos que somente podemos nomeá-la "informação" se a compreendemos, ou seja, se existe por parte do sujeito cognoscente consenso em relação ao seu significado, caso contrário não é informação. Assim, o sujeito cognoscente ressignifica a informação, uma vez que infere síntese e contexto a ela.

Partimos do pressuposto de que a busca, o uso e a apropriação da informação estão relacionados a uma ação, mesmo que inconscientemente. Tal condição qualifica a informação com um insumo extremamente relevante para distintos contextos (Valentim, 2008).

As organizações se desenvolvem a partir da aprendizagem organizacional, cujo alicerce está relacionado à informação e ao conhecimento, visto que a aprendizagem se dá a partir da experiência e reconstrução de uma ação (Choo, 2003). A aprendizagem organizacional se vale de um processo dual, pois ao mesmo tempo relaciona e isola, associa e dissocia, analisa e sintetiza. Esses movimentos dialógicos estão alicerçados em informação e conhecimento e é essa dinâmica que proporciona a ação (Morin, 1999).

A gestão da informação e a gestão do conhecimento são modelos de gestão complementares, pois, enquanto a gestão da informação atua diretamente junto aos fluxos formais, isto é, o que está explicitado, a gestão do conhecimento atua diretamente junto aos fluxos informais, isto é, o que não está explicitado (Valentim, 2007).

O universo informacional é extremamente complexo e, por isso, atende de forma distinta às necessidades informacionais dos indivíduos. Nesse sentido, a cultura informacional precisa ser trabalhada em relação à produção, ao compartilhamento, ao uso e à apropriação da informação. Assim, é essencial conhecer o comportamento e as 
competências essenciais para a ação do indivíduo reconhecer as próprias necessidades informacionais, primeiro passo do processo informacional.

A comunicação informacional necessita de uma mediação eficiente, assim os indivíduos envolvidos no processo devem propiciar uma dinâmica de retroalimentação constante. Portanto, o conhecimento coletivo e o conhecimento individual são frutos das interações entre os indivíduos e também das interações entre os indivíduos e os sistemas de informação.

Alguns pesquisadores da área de ciência da informação defendem que o objeto da área é a "informação registrada" e consideram o conhecimento ou o usuário elementos periféricos aos estudos da área. Contudo, se as ações para organizar, tratar e recuperar a informação têm um propósito, um contexto, um público, e só faz sentido relacionadas a essas variáveis, é impossível não estudar os fenômenos relacionados à compreensão, à apropriação e ao uso da informação por parte dos indivíduos. A gestão da informação e a gestão do conhecimento se preocupam com isso e desenvolvem metodologias que abrangem todos esses aspectos.

\section{Mediação da informação}

A mediação da informação se constitui em um segmento da ciência da informação e se articula com os outros segmentos que dela fazem parte. No entanto, propomos a mediação da informação como objeto ou núcleo epistemológico da ciência da informação.

O conceito de mediação é resultado de estudos e reflexões desenvolvidos a partir de 2001:

Mediação da informaçãoé toda ação de interferência - realizada pelo profissional da informação -, direta ou indireta, consciente ou inconsciente, singular ou plural, individual ou coletiva, que propicia a apropriação de informação que satisfaça, plena ou parcialmente, uma necessidade informacional. (Almeida Jr., 2008) 
No conceito, duas concepções devem ser destacadas: a interferência e a apropriação. A interferência opõe-se a uma forma de pensar constantemente veiculada e defendida na área: a de que o profissional da informação, os espaços em que atua e as técnicas, ferramentas e instrumentos que utiliza são neutros. Com base nessa neutralidade é possível também afirmar que todo o fazer desse profissional é imparcial e apolítico. Afirmando como determinante e inquestionável a interferência nesse fazer, advogamos outro caráter e outra postura do profissional da informação.

A neutralidade - se fosse possível - eliminaria ou tornaria quase improvável a manipulação. Essa ideia permeia muitos textos da área e fundamenta a concepção da imparcialidade. Sendo neutras ou imparciais, a influência e ação do profissional da informação na sociedade são nulas. Assim, poderia ser considerado um profissional passivo, mero objeto, não sujeito da história. Seria também um reprodutor de formas de entender e explicar o mundo, quase sempre presentes nos discursos das classes dominantes, pois são elas as que, dentro da constituição atual da sociedade - determinada por elas -, inserem seus interesses, pontos de vista e a própria história como os únicos possíveis e verdadeiros. A história que se mantém, e entendida como oficial, é a dos vencedores.

Como reprodutor, o profissional da informação reforça e sustenta os interesses e a ideologia de determinadas classes, permitindo a manutenção de uma situação favorável a uma minoria. A informação trabalhada nesse contexto torna-se instrumento de exclusão.

Convém lembrar que historicamente o bibliotecário, profissional da informação que atua dentro de parâmetros específicos da informação, sempre esteve ao lado dos excludentes, defendendo seus interesses e preservando os documentos e suportes empregados como instrumentos de manutenção do poder exercido por eles.

A apropriação, por sua vez, opõe-se à ideia de uso, já que esse carrega em seu bojo, quando entendido no âmbito da informação, uma concepção funcionalista. Em verdade, não fazemos uso da informação, mas, por meio dela, alteramos, modificamos, transfor- 
mamos nosso conhecimento. É com esse conhecimento transformado que nos relacionamos com o mundo.

A ideia de apropriação pressupõe entendimento. $\mathrm{O}$ acesso físico aos suportes apenas inicia o processo de apropriação, não sendo de nenhuma maneira sua conclusão.

Nossas reflexões, hoje, apontam para uma apropriação voluntária e involuntária, consciente e inconsciente. Se sempre voluntária e consciente, a apropriação, assim entendida, implicaria a concepção de um pleno e total controle das informações no âmbito da recepção. Não haveria, assim, manipulações, informações sub-reptícias, subliminares etc.

Além disso, nossas reflexões também se dirigem e se preocupam com a desinformação, com a contrainformação.

Entre os autores que embasam nossas posições, vale destacar: Paulo Freire, Vigotsky, Robert Kurz, Newton Duarte, Ignácio Ramonet, Emir Sader, Philippe Breton, Marilena Chauí, entre outros.

Entendemos que a construção do conhecimento dá-se individualmente, embora, necessariamente, na relação com o mundo. Dessa forma, o conhecimento é individual e coletivo; o ser humano é um indivíduo, mas dependente dos outros e do mundo.

Com base nessa ideia, a informação não existe antecipadamente, não se materializa como mercadoria, ao contrário, subjetiva, propicia a transformação do conhecimento quando apropriada.

De maneira diferente do entendimento mais disseminado e aceito na área, compreendemos a informação como causa de conflitos, criadora de indagações, dúvidas, curiosidades, e não como eliminadora de incertezas. Efêmera, existe apenas no intervalo entre a relação do sujeito com o suporte e a apropriação. Essa, como já dito anteriormente, pode ser voluntária ou involuntária, consciente ou inconsciente.

Outra defesa que fazemos é que a ciência da informação deve se preocupar não apenas com a informação científica e tecnológica, mas também, e em igual medida, com a informação pública, com a informação social; deve interessar-se pelas tecnologias, embora não as 
tendo como imprescindíveis, ou seja, seu campo abarca ações, práticas, fazeres, pesquisas, estudos e reflexões em que elas estejam ou não presentes.

No âmbito de suas preocupações, a ciência da informação deve ter presente a informação não registrada. Alguns segmentos da área lidam, necessariamente, com a informação registrada. Não é o caso, por exemplo, da disseminação e, de maneira mais abrangente, da mediação da informação que estuda e pesquisa, entre outros, a oralidade; que volta seus olhos para as atividades culturais, a ação cultural, a leitura, a mediação da leitura, a animação da leitura. Preocupa-se, além disso, com a recepção da informação, com as influências, manipulações, ideologias que ela carrega em seu bojo. Direciona suas análises para os interesses, os embates, as lutas de ideias e concepções que estão presentes na construção do conhecimento.

Existindo apenas num átimo de tempo, o profissional da informação atua com uma informação que ainda não se fez, que está em potência, uma quase-informação, uma possível-informação, uma provável-informação. Nós a denominamos protoinformação.

O estudo da mediação levou-nos a dividi-la em dois grandes segmentos no âmbito do fazer do profissional da informação: a mediação implícita e a mediação explícita. Esta última ocorre nos espaços em que há, claramente, uma relação formal entre o usuário e o equipamento informacional. A mediação, nesse caso, é explícita e facilmente reconhecida em seus aspectos materiais, concretos. Quanto à mediação implícita, ela ocorre em cada ação do profissional da informação, tanto no armazenamento como no processamento e em outros trabalhos por ele desenvolvidos. Ela é implícita, pois está por trás dos objetivos desses setores. Qualquer ação, dentro do fazer do profissional da informação, deve ter a apropriação da informação por parte do usuário, como seu objetivo principal. Sem isso, a ação justifica-se por si mesma e se consome em seu próprio espaço, em seu próprio fazer.

De forma sucinta e resumida, procuramos apresentar as ideias, os conceitos e as concepções que norteiam nossos estudos, pesqui- 
sas e reflexões sobre a mediação da informação, bem como aspectos e segmentos a ela vinculados.

\section{Elementos semióticos da mediação e apropriação da informação}

A construção do conhecimento no contexto dos espaços de informação depende de condições simbólicas na produção da linguagem. A mudança da informação para o conhecimento supõe uma tradução sígnica para efetivar a comunicação, especialmente a interpessoal. Nesse contexto é que se notam os pontos de encontro entre a semiótica e as teorias ligadas à gestão, mediação e apropriação da informação, fundamentais ao campo da ciência da informação. Objetivamos nesta seção elencar algumas iniciativas de diálogo da mediação e apropriação da informação com a semiótica de extração peirciana, ou mais especificamente os conceitos aplicados a esse contexto em especial.

Por semiótica consideramos o estudo dos signos naturais e artificiais, em suas várias perspectivas teóricas. Entre essas, destacamos, por um lado, a leitura semiológica dos sistemas sígnicos que retoma a tradição saussuriana e estruturalista, e, por outro, a interpretação dos fenômenos sígnicos sugerida pela semiótica de Charles Peirce (1839-1914). Sob essa última abordagem, refletiremos sobre as possibilidades de contribuição ao campo da mediação e apropriação da informação, na medida em que essa área destaca as interfaces teóricas e aplicadas para a compreensão dos processos de geração do conhecimento.

Assumimos como premissa inicial que, além das configurações sociais, culturais e comportamentais da mediação e da apropriação da informação, deve-se refletir sobre os dispositivos semióticos que amparam a transformação de dados em informação, e esses em conhecimento - caso essa fórmula seja válida para compreender a dinâmica da construção do conhecimento em vários ambientes informacionais -, compreendendo não apenas unidades de 
informação tradicionais como bibliotecas, mas empresas, espaços públicos etc.

A semiótica, fundada pelo filósofo estadunidense Charles Peirce, sugere que todo o processo de criação de conhecimento está condicionado à interpretação sígnica, que pode ser compreendida pelas traduções de códigos levadas a cabo pelos sujeitos envolvidos. Evidentemente, Peirce não investigou apenas os signos provindos da sistematização da linguagem humana, contudo alguns parâmetros da semiótica geral podem ser úteis à discussão.

Sendo a teoria dos signos de Peirce também uma teoria da comunicação, ela poderia projetar-se como um substrato teórico da mediação da informação. Semelhante interesse pela semiótica é alcançado no estudo dos processos cognitivos da apropriação da informação, os quais são reconhecidamente atividades semióticas, regidas por precondições lógicas à atribuição de significados.

A aplicação da semiótica no campo da mediação da informação deve levar em conta ainda a malha conceitual da teoria de Peirce. Se mediação é um processo semiótico que ocorre na interação dos agentes informadores, localizados social e culturalmente, no intuito de comunicar informação e com ela transformar o conhecimento, ela deve resgatar da teoria semiótica, sobretudo, os conceitos de hábito mental e semiose. O mesmo grau de contribuição pode ser obtido pela consulta ao conceito de iconicidade, a respaldar a leitura dos processos de apropriação da informação, assumindo esse como processo de atribuição de significado pelo sujeito, o qual decorre de uma empatia entre ícones e signos convencionais.

Para efeito de revisão conceitual, a contribuição primeira da semiótica para a ciência da informação foi sentida nos processos de organização da informação, em especial, na análise documental de conteúdo. Por análise compreende-se o processo que visa resgatar os elementos de conteúdos de discursos e transpô-los, por meio da tradução dos códigos em outra forma, com a finalidade de facilitar a recuperação da informação. Peirce foi um dos filósofos mais preocupados com a linguagem, tanto que a terminologia científica era considerada um instrumento fundamental para a elaboração do 
pensamento eficiente. Sem os atributos simbólicos, os conceitos e a própria comunicação científica seriam irrealizáveis. Toda terminologia deve seguir uma ética de conduta para o uso dos conceitos, e esses têm uma natureza que não se distingue das características sígnicas, isto é, a de fazer avançar o pensamento.

Ademais, é um fato que o pragmatismo de Peirce é um método de admissão de hipóteses razoáveis. Considerado em si mesmo, é o próprio método da ciência em que se procuram fixar novas crenças. Peirce erigiu uma teoria lógica de grande utilidade à análise da informação - processo anterior e estratégico às atividades de gestão e mediação -, pois esses processos são naturalmente regulados pelos três tipos de inferência (abdução, dedução e indução) propostos pelo autor. Contudo, os estudos sobre a intersecção entre semiótica e organização da informação de Mai (1997a, 1997b, 2000, 2001) e Thellefsen (2002, 2003, 2004) ainda não refletem, de forma sistemática, nos cursos de graduação e pósgraduação em ciência da informação, muito menos no âmbito do campo profissional.

Os fluxos informacionais proporcionados pela mediação e apropriação da informação correspondem à outra ponta da cadeia sígnica, a qual deve ser objeto de análise da semiótica. As ações de mediação da informação que visam à continuidade da relação entre informação e sujeito, mediante dispositivos simbólicos, e a atividade pessoal de apropriação da informação, o que provisoriamente podemos designar como a interpretação e a atribuição de significado ao conteúdo informacional, sugerem que outros elementos da semiótica precisam ser relacionados.

Em primeiro lugar, mediação e apropriação da informação não são fenômenos destituídos de interação social, constituída e consolidada pelo uso da linguagem. Em segundo, todo processo linguístico, com a finalidade de aproximar esferas diferentes do universo da informação, depende de tradução sígnica. Presumese que a tradução semiótica seja mesmo uma das principais características do trabalho do profissional da informação. Em terceiro, ambos os processos mencionados ocorrem em um contínuo 
fenomênico, em que a interrupção do fluxo informacional é apenas uma etapa do processo que procura criar ininterruptamente o conhecimento.

Além disso, nenhum conhecimento, tratado do ponto de vista da ciência da informação, poderia ser construído sem a presença de estratégias institucionais de tradução semiótica. Nesses termos, a mediação da informação antecipa o processo de tradução originando, em certa medida, a apropriação da informação, talvez até defina as categorias em que se operará a aquisição de novos conhecimentos.

Em ambientes informacionais, o conhecimento construído por um grupo de pessoas depende das interpretações anteriores consolidadas em hábitos mentais. A descoberta desses hábitos, tal como sugere a tese pragmatista, conduz à antecipação das relações de significados que os sujeitos estão predispostos a estabelecer. A despeito da possível interpretação comportamentalista dessa tese, a questão do hábito mental como mecanismo semiótico, que restringe as opções de conhecimento na fixação das crenças, é um pressuposto lógico e não psicológico.

A crença deve ser, em primeiro lugar, "algo de que estamos cientes; segundo, aplaca a irritação da dúvida; e, terceiro, envolve o surgimento, em nossa natureza, de uma regra de ação ou, digamos com brevidade, o surgimento de um hábito" (Peirce, 1972, p.56). Ao passo que a crença interrompe as sensações provocadas pela dúvida, o sujeito entra em um estágio de harmonização com a crença obtida, esperando um futuro momento em que possa ser incomodado pelas necessidades de investigação provocadas pelo incômodo da dúvida.

No caso específico do conhecimento técnico-científico e especializado, o sujeito inicia seu processo de atualização quando recebe novamente a sensação desagradável da dúvida. A verdade, para Peirce, é essa novidade que, acalmada, faz iniciar o processo de crença à mente com o objetivo de transformá-la em um novo hábito.

No campo da apropriação da informação encontra-se no conceito de hábito um dispositivo que leva a ação interpretativa a agir em um futuro da mesma forma que no passado. Tal como se as condições de interpretação de uma informação fossem determinadas pe- 
las relações sígnicas solidificadas por experiências anteriores. O que torna uma informação familiar, do ponto de vista do usuário, é a sua capacidade de se fazer semelhante à experiência passada.

O processo de interpretação ininterrupta e atualização do signo, também conhecida na semiótica peirciana como semiose (ação do signo), objetiva representar o interpretante (efeito de significado) de um signo anterior, e distancia-se cada vez mais do objeto como ele é. Como o processo de interpretação não tem um fim preestabelecido, o produto dele será, mais cedo ou mais tarde, substituído. Portanto, a representação é falível ontologicamente à medida que depende de experimentações futuras para gerar uma interpretação sempre mais exata.

Entre os marcos conceituais da semiótica é de fundamental importância para entender os fenômenos informativos examinar a ocorrência da semiose em ambientes informacionais. Em qualquer espaço de informação, não se pode esquecer da linguagem. A mediação da informação também viabiliza a tradução sígnica e o domínio das várias linguagens, verbal, visual e sonora, e acelera o processo de disponibilização da informação. Um usuário precisa ter sua necessidade interpretada e ter condições semióticas para se apropriar da informação. A mediação preside a fluidez da semiose em ambientes informativos.

É, entretanto, pela familiaridade, ou melhor, pela iconicidade que o reconhecimento de qualquer informação se torna possível. Nenhuma tomada de decisão ou apropriação da informação pode ser realizada sem o fator iconicidade. Por ícone, entende-se o signo de semelhança. É o mais elementar signo que se pode produzir sobre um objeto qualquer. Pode-se afirmar que é o estado elementar do significado, isto é, o primeiro estágio da significação é supor relações de semelhança. Esse conceito se refere mais propriamente às ações da apropriação.

Todo signo que enseja representar seu objeto é necessariamente um ícone, pois deve referenciar o objeto por alguma semelhança que só pode ser uma qualidade apresentada tanto no signo quanto no objeto. "Um ícone é um signo que se refere ao objeto que denota 
simplesmente por força de caracteres próprios e que ele possuiria, da mesma forma, existisse ou não existisse efetivamente um objeto daquele tipo" (Peirce, 1972, p.101). O ícone refere-se ao objeto por alguma semelhança ou similaridade. A simples semelhança é uma das formas de ser da primeiridade - uma das três categorias fenomenológicas propostas por Peirce -, pois é a identidade estabelecida entre qualidades.

Em qualquer estratégia de apropriação da informação, o primeiro elemento que aproxima as expectativas do usuário e o liga à potencial informação - e aqui assumimos as possibilidades de informação - é o ícone na forma de uma produção de ligações de semelhança entre dois polos: objeto e signo.

Conceitos como os de hábito mental, semiose e iconicidade, encontrados na filosofia e semiótica peirciana, são fundamentais para a compreensão dos processos disseminativos - tal como a mediação da informação - e dos elementos semiótico-cognitivos. Pesquisas no campo da gestão, mediação e uso da informação devem considerar tal arcabouço teórico para entender a dinâmica da produção dos significados em espaços informacionais.

\section{Busca, uso e apropriação da informação}

Um dos principais focos da ciência da informação, conforme Hjörland (2003, p.88), refere-se à interação entre produtores de conhecimento, usuários, intermediários e os sistemas informacionais:

Cada um desses atores possui certos pré-entendimentos, visões, conceitos e linguagens adquiridas durante a sua socialização na sociedade. O sucesso da interação (entre produtores de conhecimento, usuários, intermediários e os sistemas de registro bibliográfico) depende desses pré-entendimentos, conceitos e linguagens. (tradução nossa)

Albrechttsen \& Höjrland (1997) consideram que a teoria formulada a partir do estudo do comportamento do usuário pode 
contribuir para fundamentar a base da ciência da informação, uma vez que várias questões fundantes da área são subordinadas a ela. Conhecer as necessidades dos usuários é fundamental para que possamos planejar, construir, gerir e avaliar serviços e produtos informacionais. A própria formação do bibliotecário deve salientar a necessidade de se conhecer as características do grupo de usuários que se pretende atender. De outra forma, o usuário que possui distintas opções de acesso à informação dará preferência àquela que for mais acessível ou com a qual mais se identifica, mesmo que essa não seja necessariamente a melhor. Esse fator pode acarretar a um distanciamento cada vez maior do usuário das unidades de informação.

Vários fatores contribuíram para que o estudo das características e comportamento dos usuários adquirisse o status de um dos temas mais recorrentes na literatura produzida na área (Ondrusek, 2004). Os estudos sobre comportamento de usuários vêm da tradição dos estudos de usuários, sendo que os primeiros remontam ao século XIX (Calva González, 1999). Conforme Case (2007), os estudos sobre comportamento de usuários tiveram início nos anos 1960. Porém, até esse período, as pesquisas enfocavam as fontes utilizadas pelos usuários para obterem a informação desejada, como o uso de periódicos, de serviços ou produtos de informação. O objetivo maior dessas pesquisas era avaliar os sistemas de informação (Choo \& Auster, 1993; Vakkari, 1999 apud Case, 2007).

A partir dos anos 1970, os estudos ampliam seu escopo e passam a considerar o indivíduo como produtor e usuário de informação, não mais restritos a um sistema de informação específico.

Outro fator que contribuiu para a valorização dos estudos sobre o comportamento dos usuários refere-se ao desenvolvimento das Tecnologias de Informação e Comunicação (TIC), ocorrido na década de 1980. As TIC possibilitaram o acesso dos usuários a diversos sistemas de informação sem necessariamente depender de um intermediário, um mediador, como o bibliotecário Debowski (2001) e Rowley (2002), tendência potencializada com a disseminação da rede internet. 
A constatação da importância desse tipo de estudo pode ser observada pela quantidade de publicações sobre o tema na literatura da área. O levantamento realizado por Ondrusek (2004) na base de dados Library and Information Science Abstracts (Lisa) entre os anos 1980 e 2000, por exemplo, revelou a existência de 270 artigos publicados apenas em língua inglesa. Em busca recente (outubro de 2009) nessa mesma base de dados referente aos últimos dez anos (2001 a 2010) foram encontrados 260 artigos em língua inglesa. Assim, na última década, a quantidade de artigos produzidos foi o equivalente à dos vinte anos anteriores.

O comportamento informacional abrange todas as ações passivas ou não intencionais em que há o contato com a informação pertinente, até as ações intencionais de busca e uso da informação Case (2007) e Wilson (2000, p.49), conforme segue:

Comportamento informacional é a totalidade do comportamento humano em relação às fontes e aos canais de informação, incluindo a busca de informação ativa e passiva, além do uso da informação. Ou seja, inclui a comunicação face to face com outras fontes e canais de informação, e também a recepção passiva de informação, como, por exemplo, assistindo a anúncios de televisão, sem nenhuma intenção para agir na informação dada.

Esse comportamento é influenciado por diversos fatores, tais como a disponibilidade de suportes de informação, normas de comportamento apropriado e crenças individuais. Portadores de informação incluem distintos canais, variadas fontes desses canais e as mensagens contidas nessas fontes (Johnson et al., 2006).

Todos esses elementos compõem o contexto em que ocorrem as buscas informacionais e não podem ser ignorados. Conforme Cool \& Spink (2002) há diversas acepções para o termo contexto, que variam conforme o enfoque do pesquisador sobre o usuário e suas ações. Porém, de uma forma geral, podemos defini-lo como o conjunto de fatores cognitivos, sociais, culturais e outros relacionados à tarefa, ao objetivo e às intenções de uma pessoa quando inicia a atividade de busca por informação. 
Case (2007) faz uma extensa revisão da literatura (1990-2001) e aponta que é possível verificar três principais focos das pesquisas sobre comportamento informacional:

1. Categorias profissionais: médicos, engenheiros etc.;

2. Papéis desempenhados pelos indivíduos: consumidores, donas de casa etc.;

3. Grupos demográficos: idosos, jovens, crianças etc.

Os estudos sobre indivíduos de determinadas categorias profissionais são os que concentram a maior parte das pesquisas. Os cientistas e os engenheiros são as duas categorias profissionais mais comumente estudadas.

Nas pesquisas desenvolvidas pelos pesquisadores dos grupos de pesquisa da Unesp, câmpus de Marília, notam-se dois enfoques que se complementam: o primeiro voltado ao estudo do comportamento de usuários atuantes em espaços empresariais de distintos segmentos econômicos e o segundo dedica-se ao estudo do comportamento de usuários em ambientes educacionais, tais como universidades, programas de pós-graduação e Ensino Fundamental, bem como determinadas categorias profissionais, tais como advogados, por exemplo.

Os estudos voltados para o usuário, conforme mencionado anteriormente, têm crescido sensivelmente no país, fato que demonstra que a área está preocupada com a mediação, a recepção e a apropriação dos conteúdos informacionais.

\section{Considerações finais}

Os estudos teóricos e metodológicos de processos que envolvam a gestão, a mediação, o uso e a apropriação da informação em distintos ambientes são importantes no contexto das ciências pós-modernas, visto que interage e dialoga com outras áreas do conhecimento. Destacamos as principais interfaces: ciências cognitivas, comunica- 
ção, administração, sociologia, linguística, educação, além de interagir com áreas constitutivas da própria ciência da informação como a biblioteconomia, a documentação e a arquivologia.

O núcleo de interesse da linha de pesquisa volta-se aos estudos teóricos e metodológicos de temáticas relacionadas à cultura, comportamento e competência em informação; aos fluxos, processos, usos e usuários da informação; aos processos de comunicação, mediação e de apropriação da informação; à gestão da informação, gestão do conhecimento e aprendizagem informacional; à inteligência empresarial, prospecção e monitoramento informacional; às redes sociais; às políticas e práticas de informação e leitura.

Finalmente, ressaltamos a importância de uma articulação constante entre a pós-graduação e a iniciação científica, formando pessoas que sejam críticas e construtoras de conhecimento científico válido. Nesse contexto, defendemos que a responsabilidade social da linha de pesquisa refere-se à formação acadêmico-científica ampla e à interação com a sociedade, portanto, tem papel primordial para as ciências pós-modernas e, nesse caso, para a ciência da informação.

\section{Referências}

ALBRECHTTSEN, H.; HJÖRLAND, B. Information seeking and knowledge organization. Knowledge Organization, v.24, n.3, p.13644, 1997.

ALMEIDA JUNIOR, O. F. de. Mediação da informação: ampliando o conceito de disseminação. In: VALENTIM, M. (Org.) Gestão da informação e do conhecimento. São Paulo: Polis; Cultura Acadêmica, 2008a. p.41-54.

Mediação da informação e múltiplas linguagens. In: ENCONTRO NACIONAL DE PESQUISA EM CIÊNCIA DA INFORMAÇÃ̃ O, 9, 2008, São Paulo. Anais... São Paulo: ANCIB, 2008 b. . Mediação da informação e múltiplas linguagens. Tendências da Pesquisa Brasileira em Ciência da Informação, v.2, n.1, jan./dez. 2009a. 
La mediación de la información y la lectura informacional. In: GARCIA MARCO, F. J. (Ed.) Avances y perspectivas en sistemas de información y documentación: 2009. Zaragoza: Universidad de Zaragoza, 2009b. p.23-8.

ALMEIDA JUNIOR, O. F. de; BORTOLIN, S. Mediação da informação e da leitura. In: SILVA, T. E. da. (Org.) Interdisciplinaridade e transversalidade em Ciência da Informação. Recife: Néctar, 2008. p.67-86.

BORTOLIN, S.; ALMEIDA JUNIOR, O. F. de. Bibliotecário: um essencial mediador de leitura. In: SOUZA, R. J. de. Biblioteca escolar e práticas educativas: o mediador em formação. Campinas: Mercado de Letras, 2009. p.205-18.

CALVA GONZÁLEZ, J. J. El comportamiento en la búsqueda de información de los investigadores del área de humanidades y ciencias sociales. Investigación Bibliotecológica, v.13, n.27, p.11-40, jul./dic. 1999.

CHOO, C. W. A organização do conhecimento: como as organizações usam a informação para criar significado, construir conhecimento e tomar decisões. São Paulo: Senac, 2003. 425p.

COOL, C.; SPINK, A. Information retrieval (IR) in context. Information Processing and Management, v.38. n.5, p.605-11, 2002. DEBOWSKI, S. Wrong way: go back! An exploration of novice search behaviors while conducting an information search. The Electronic Library, v.19, n.6, p.371-82, 2001.

HJÖRLAND, B. Fundamentals of knowledge organization. Knowledge Organization, v.30, n.2, p.87-111, 2003.

JOHNSON, J. D. et al. Fields and pathways: contrasting or complementary views of information seeking. Information Processing and Management, v.42 n.2, p.569-82, mar. 2006.

MAI, J.-E. The concept of subject: on problems in indexing. In: McILWAINE, I. C. (Ed.) Knowledge organization for information retrieval: $6^{\text {th }}$ International Study Conference on Classification Research. The Hague: FID, 1997a. p.60-7 (FID, n.716).

The concept of subject in a semiotic light. In: SCHWARTS, C.; RORVIG, M. (Ed.) Digital collections: implications for users, funders, developers and maintainers. Medford: Information Today, 1997b. p.54-64 (Proceedings of the ASIS Annual Meeting, n.34). 
The subject indexing process: an investigation of problems in knowledge representation. Austin, 2000. 344f. Dissertation (Doctor of Philosophy) - Faculty of Graduate School of Library and Information Science, The University of Texas at Austin.

Semiotics and indexing: an analysis of the subject indexing process. Journal of Documentation, London, v.57, n.5, p.591-22, Sep. 2001.

MORIN, E. O método 3: o conhecimento do conhecimento. Porto Alegre: Sulina, 1999. 288p.

ONDRUSEK, A. L. The attributes of research on end-user online searching behavior: A retrospective review and analysis. Library and Information Science Research, v.26, n.2, p.221-65, 2004.

PEIRCE, C. S. Semiótica e filosofia. São Paulo: Cultrix, 1972. Escritos coligidos. 2.ed. São Paulo: Abril Cultural, 1980.

ROWLEY, J. A biblioteca eletrônica. 2.ed. Brasília: Briquet de Lemos, 2002.

SAINSAULIEU, R.; KIRSCHNER, A. M. Sociologia da empresa: organização, poder, cultura e desenvolvimento no Brasil. Rio de Janeiro: DP\&A, 2006. 464p.

THELLEFSEN, T.L. _ Semiotic knowledge organization: theory and method development. Semiotica, v.142, n.1/4, p.71-90, 2002. . Pragmaticism and the role of terminology. Impact: an electronic journal on formalization in text, media and language, abr. 2003. Disponível em: <http://www.impact.hum.auc.dk>. Acesso em: 5 maio 2007.

Knowledge profiling: the basis for knowledge organization. Library Trends, v.52, n.3, p.507-14, Winter 2004.

VALENTIM, M. L. P. (Org.) Informação, conhecimento e inteligência organizacional. 2.ed. Marília: Fundepe, 2007.278p.

. Gestão da informação e do conhecimento no âmbito da Ciência da Informação. São Paulo: Polis: Cultura Acadêmica, 2008. 268p.

WILSON, T. Human information behavior. Information Science, v.3, n.2, p.49-55, 2000. 



\section{2 \\ GESTÃO DO CONHECIMENTO NAS ORGANIZAÇÕES: PERSPECTIVAS DE USO DA METODOLOGIA SISTÊMICA SOFT (SOFT SYSTEMS METHODOLOGY) ${ }^{1}$}

Cássia Regina Bassan de Moraes Bárbara Fadel

\section{Introdução}

A aplicação e o uso do conhecimento nas organizações são uma questão complexa, com diversas dimensões diferentes. Uma dessas dimensões é a cultural. Dessa forma, pode-se questionar se cultura de uma organização recompensa decisões e ações de acordo com a maneira como as pessoas utilizam e compartilham o seu conhecimento, ou se apenas está satisfeita com o uso disseminado da intuição e da adivinhação à custa de organizar pessoas e processos para aplicação dos melhores conhecimentos, experiências e competências a projetos e tarefas.

Para tanto, as organizações necessitam tratar seus colaboradores como sujeitos na sua totalidade e complexidade, ou seja, como parceiros cujas potencialidades precisam ser incentivadas e valorizadas, uma vez que todos os integrantes da organização participam da cadeia informacional e de criação do conhecimento, já que são as pes-

1 Este capítulo inclui partes do levantamento teórico sobre a Metodologia Sistêmica Soft da tese de doutoramento Gestão do conhecimento nas organizações: modelo conceitual centrado na cultura organizacional e nas pessoas. 
soas que se vinculam com os usuários e com os fornecedores, e são elas que tomam decisões; também são elas que concebem os produtos e serviços, buscando atender às necessidades dos clientes (Ponjuán Dante, 2007, p.91).

Além disso, deve-se levar em conta que o conhecimento é criado apenas pelos indivíduos, ou seja, uma organização não pode criar conhecimento por si mesma, sem os indivíduos. Dessa forma, é muito importante que a organização apoie e estimule as atividades criadoras de conhecimento dos indivíduos ou que proporcione os contextos apropriados para elas (Takeuchi \& Nonaka, 2008, p.25).

A interação com a informação para a geração de conhecimento nas organizações é, porém, uma questão complexa com diversas dimensões diferentes, sendo uma dessas a cultural, que se constitui num tipo de conhecimento organizacional, segundo Choo (2003, p.188). A partir da classificação de Boisot, o autor propõe a classificação do conhecimento nas organizações como tácito, explícito e cultural, sendo este último caracterizado na seguinte conformidade:

O conhecimento cultural consiste em estruturas cognitivas e emocionais que habitualmente são usadas pelos membros da organização para perceber, explicar, avaliar e construir a realidade. O conhecimento cultural inclui as suposições e crenças usadas para descrever e explicar a realidade, assim como as convenções e expectativas usadas para agregar valor e significado a uma informação nova. Essas crenças e valores compartilhados formam a estrutura na qual os membros da organização constroem a realidade, reconhecem a importância de novas informações e avaliam ações e interpretações alternativas. Como no conhecimento de senso comum de Boisot, o conhecimento cultural não é codificado, mas amplamente divulgado ao longo de vínculos e relacionamentos que ligam o grupo. (Choo, 2003, p.190)

Dessa forma, pode-se afirmar que, para a criação de conhecimento em uma organização, a cultura organizacional ${ }^{2}$ deve estar voltada

2 Segundo Schein (1992), cultura organizacional "é um conjunto de pressupostos básicos que um grupoinventou, descobriu ou desenvolveu ao aprender como 
para recompensar decisões e ações de acordo com a maneira como as pessoas utilizam e, especialmente, compartilham o seu conhecimento, uma vez que o conhecimento é criado por meio das interações entre os seres humanos e seu ambiente, e que as pessoas são parte do ambiente e o ambiente faz parte das pessoas (Nonaka \& Toyama, 2008, p.96).

Assim, lança-se a hipótese de se trabalhar com a Metodologia Sistêmica Soft (Soft Systems Methodology - SSM) para a gestão do conhecimento nas organizações, levando-se em consideração a cultura organizacional e a gestão de pessoas. A Metodologia Sistêmica Soft foi criada na década de 1980 por Peter Checkland, procurando dar conta de situações problemáticas nas quais a abordagem quantitativa não pode ser aplicada, não apenas graças à complexidade ou incerteza existente, mas também por haver a necessidade de se enfatizar os aspectos subjetivos envolvidos em tais situações, como será visto a seguir.

\section{Gestão do conhecimento}

Quando se pretende fazer a gestão de algo, de qualquer coisa, depara-se com o problema importante de se saber em que consiste esse algo para poder identificá-lo e realizar, num segundo momento, a sua gestão. Porém, uma vez solucionado esse problema, automaticamente aparece uma segunda dificuldade, e não de menor intensidade: essa gestão deve tentar ajustar-se à natureza e características daquilo que se quer gerir (Pérez-Montoro Gutiérrez, 2008, p.53).

Ainda segundo Pérez-Montoro Gutiérrez (2008, p.53), esse novo problema se repete quando se pretende implantar um processo de gestão do conhecimento em uma organização. Partindo-se do pres-

lidar com os problemas de adaptação externa e de integração interna, pressupostos estes que funcionam bem o suficiente para serem considerados válidos e ensinados aos novos membros como forma correta de perceber, pensar e sentir, em relação a esses problemas". 
suposto de que há distintos tipos de conhecimento em uma organização, há que ter em conta a natureza especial de cada um deles para poder-se optar pela gestão mais adequada.

Segundo Davenport (2004), a maioria dos administradores não entende a natureza da relação entre as pessoas e a informação e desconhece qual é o tipo de informação necessário às várias pessoas dentro de uma organização, não consegue definir como diferentes colaboradores chegam a um consenso quanto ao significado de uma informação nem determinar o que motiva os indivíduos a compartilhar ou a estocar informações.

Segundo o autor, um dos motivos pelos quais as organizações efetivamente não administram a informação é a falta de percepção de como seria se elas o fizessem. Os gestores não sabem quais abordagens adotar ou quais benefícios poderiam ser obtidos. Eles simplesmente nunca viram exemplos de enfoques na informação e não na tecnologia. Entretanto, se tivessem escolha, é bem possível que optassem pela via da informação.

Davenport (2004, p.16) chega à conclusão de que os progressos efetuados nessa área são resultado, em grande parte, do surgimento da "gestão do conhecimento". Na prática, muitas empresas dispõem de ambos, conhecimento e informações, nas suas iniciativas em gestão do conhecimento e reconhecem a importância do fator humano no conhecimento, mesmo que suas organizações tenham se concentrado na tecnologia. Sendo assim, existe a necessidade de a informação e o conhecimento serem gerenciados da mesma forma que os recursos financeiros, materiais e humanos.

Essa crescente necessidade de se gerenciar a informação, levando-se em conta também os aspectos humanos e as tecnologias de informação e comunicação, resultou na formação de uma área profissional, originalmente chamada de Information resources management. Essa expressão foi traduzida, no Brasil, como Gerenciamento de recursos informacionais, e é atualmente mais conhecida como Gestão da informação (Moraes \& Fadel, 2006, p.107).

Ainda segundo as autoras, essa área se configura como um campo de estudo já consolidado nos Estados Unidos e na Europa cujos 
conteúdos teóricos e operacionais têm se transformado em ferramenta imprescindível para qualquer organização que necessite produzir, localizar, coletar, tratar, armazenar, distribuir e estimular a geração e o uso da informação.

A gestão da informação é o processo mediante o qual se obtêm, se desenvolvem ou se utilizam recursos básicos (econômicos, físicos, humanos, materiais) para o manejo da informação no âmbito e para a sociedade à qual serve. Tem como elemento básico a gestão do ciclo de vida desse recurso, e ocorre em qualquer organização. É própria também de unidades especializadas que manejam esse recurso de forma intensiva, chamadas de unidades de informação. Esse processo de gestão da informação deve ser valorado sistematicamente em diferentes dimensões, e o domínio de suas essências permite sua aplicação em qualquer organização (Ponjuán Dante, 2007, p.19).

Ainda segundo a autora, os fluxos de informação que ocorrem em todos os sistemas devem ser objeto da gestão da informação. Esses processos respondem a cada organização, porque tem características particulares. No geral podem ser associados a segmentos típicos da organização ou a uma dimensão. Podem ser identificadas as seguintes dimensões: o ambiente, os processos, as pessoas, a tecnologia, a infraestrutura e os produtos e serviços.

Para Pérez-Montoro Gutiérrez (2008, p.63-4), a gestão do conhecimento pode ser definida na seguinte conformidade:

A gestão do conhecimento pode ser entendida como a disciplina que se encarrega de estudar o projeto e a implementação de sistemas cujo principal objetivo é que todo conhecimento tácito, explícito, individual, interno e externo envolvido na organização possa transformar-se e converter-se, sistematicamente, em conhecimento organizacional ou corporativo de forma que esse conhecimento corporativo, ao tornar-se acessível e poder ser compartilhado, permita que aumente o conhecimento individual de todos os seus membros e que isso redunde diretamente em uma melhora da contribuição desses sujeitos no alcance dos objetivos que busca a própria organização. 
Ainda segundo o autor, a gestão do conhecimento pode também ser entendida como a disciplina que se encarrega do planejamento e da implementação de sistemas cujo principal objetivo é converter todo o conhecimento em valor para a empresa, como pode ser visto na Figura 1:

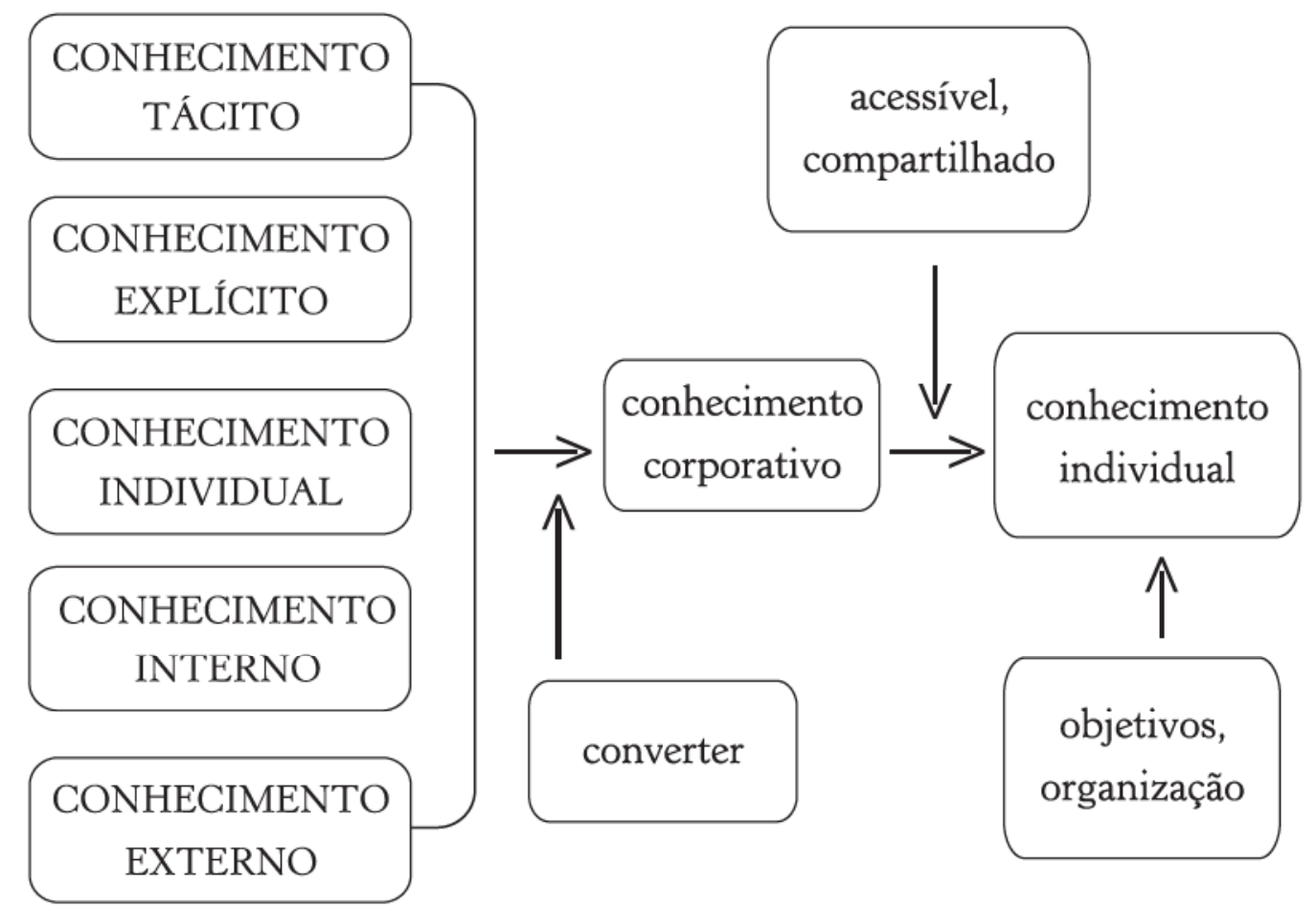

Figura 1 - Gestão do conhecimento nas organizações.

Fonte: Pérez-Montoro Gutiérrez (2008, p.64).

Pérez-Montoro Gutiérrez (2008, p.63-4), entretanto, chama a atenção para três consequências que podem ser extraídas da definição por ele proposta de gestão do conhecimento:

- o fato de o conhecimento ser compartilhado e acessível aos membros da organização produz um aumento de seu valor dentro da organização;

- todo programa de gestão do conhecimento inclui uma importante e substancial dimensão documental que não pode ser esquecida ou colocada em segundo plano; 
- é importante ressaltar que existe uma parte do conhecimento tácito envolvido nas organizações que não pode ser convertida em conhecimento corporativo.

Assim, o autor destaca que certas habilidades, como saber coordenar uma equipe de pessoas ou possuir alta e valiosa capacidade de negociação, poderiam ser identificadas como dois claros exemplos do tipo de conhecimento que não pode ser convertido em conhecimento corporativo. Dessa forma, a natureza especial desse tipo de conhecimento tácito o faz totalmente incompatível com as operações que formam a gestão do conhecimento, ou seja, esse tipo de conhecimento não pode ser diretamente gerenciado no sentido estrito. A única opção para aproveitar esse conhecimento e revertê-lo em benefício do restante da organização passa por criar as condições apropriadas para que esse possa ser gerenciado, e o contexto adequado para que, mediante processos de socialização, possa fazer-se acessível e compartilhado por toda a organização (ibidem, p.66).

Prusak (2004, p.208) afirma que o conhecimento é algo difícil para se gerenciar, porque é invisível e intangível e, assim, imensurável, e que não se sabe qual conhecimento existe no cérebro de uma pessoa, e compartilhá-lo é uma questão de escolha. Tal situação apresenta problemas para aqueles que envolvem com programas de gestão do conhecimento nas organizações, uma vez que, por sua natureza, esses programas implicam certa tangibilidade - de que algum benefício demonstrável será alcançado, melhorando o desempenho das organizações.

Identificar esse tal benefício leva os gestores a um conjunto de escolhas difíceis. Eles podem admitir que o conhecimento seja de fato invisível e prosseguir apenas pela fé; ou podem focar programas de gestão para o apoio a que as pessoas adquiram conhecimento, compartilhem-no com as outras em conversas e interações diretas e utilizem-no efetivamente em decisões e ações. 


\section{Metodologia Sistêmica Soft (SSM)}

\section{Abordagem sistêmica}

Um dos precursores da teoria geral dos sistemas foi o biólogo alemão Ludwig von Bertalanffy. Em obra intitulada Teoria dos sistemas, publicada no Brasil em 1976, o autor expõe a definição da teoria na seguinte conformidade:

A teoria geral dos sistemas tem por fim identificar as propriedades, princípios e leis característicos dos sistemas em geral, independentemente do tipo de cada um, da natureza e seus elementos componentes e das relações ou forças entre eles. (Bertalanffy, 1976, p.1)

Ainda segundo o autor, sistema pode ser definido como um complexo de elementos em interação, interação essa de natureza ordenada (não fortuita) (ibidem, p.1).

Segundo Araújo (1995, p.7), a noção de sistema engloba uma série de abordagens, tais como filosofia de sistemas (voltada para a ética, a história, a ontologia, a epistemologia e a metodologia de sistemas), engenharia de sistemas (sistemas artificiais, como robôs, processamento eletrônico de dados etc.), análise de sistemas (desenvolvimento e planejamento de modelos de sistemas, incluindo matemáticos) e a pesquisa empírica sobre sistemas (abrangendo a descoberta de leis, adequação e estudos de simulação de sistemas).

O grande sucesso da abordagem sistêmica pode ser atribuído, segundo Rapoport (1976, p.21), à insatisfação crescente da comunidade científica com a visão mecanicista, ou com o "mecanismo" como modelo universal, e à necessidade de essa mesma comunidade contrabalançar a fragmentação da ciência em especialidades quase isoladas umas das outras.

Ao abordar a questão da aplicabilidade da teoria dos sistemas, Bertalanffy (1976, p.1) a considera aberta às possibilidades dos vários campos da pesquisa científica: 
Tratando das características formais das entidades denominadas sistemas, a teoria geral dos sistemas é interdisciplinar, isto é, pode ser usada para fenômenos investigados nos diversos ramos tradicionais da pesquisa científica. Ela não se limita aos sistemas materiais, mas aplica-se a qualquer todo constituído por componentes em interação. A teoria geral dos sistemas pode ser desenvolvida em várias linguagens matemáticas, em linguagem vernácula, ou ser computadorizada.

Pode-se perceber que a definição de sistema, bem como as consequentes possibilidades de pesquisa, é abrangente o suficiente para que possa abarcar um número quase infinito de estruturas pertencentes ao mundo real, desde que estejam dispostas em partes e contem com uma coordenação, visando a uma organização. Entretanto, segundo Cavalcanti \& Paula (2006, p.3), essa organização nem sempre assegura o funcionamento contínuo do sistema, culminando, muitas vezes, em rupturas ou problemas que impedem a interação do todo, surgindo assim a necessidade da abordagem sistêmica, uma vez que essa permite a resolução de problemas a partir de um extenso olhar para o todo, em vez de se observar apenas as partes.

Schoderbek et al. (1990, p.8) sistematizam as diferenças entre a abordagem analítica e a abordagem sistêmica na seguinte conformidade:

Quadro 1 - Comparação entre abordagem analítica e abordagem sistêmica.

\begin{tabular}{lll}
\hline Características & Abordagem analítica & Abordagem sistêmica \\
\hline Ênfase & Nas partes & No todo \\
Tipo & Relativamente fechado & Aberto \\
Ambiente & Não definido & Um ou mais \\
Entropia & Tende para a entropia & $\begin{array}{l}\text { Não aplicável - o sistema interage com } \\
\text { o ambiente }\end{array}$ \\
Metas & Manutenção & Mudança e aprendizado \\
Hierarquia & Poucas & Possivelmente muitas \\
Estado & Estável & Adaptativo, busca novo equilíbrio \\
\hline
\end{tabular}

Fonte: Schoderbek et al. (1990, p.8). 
Uma análise do Quadro 1 permite observar que a análise sistêmica privilegia a ênfase no todo, ao contrário da abordagem analítica, que privilegia a abordagem das partes. Além disso, deve-se notar que o tipo de sistema proveniente da abordagem analítica é relativamente fechado, tendendo à entropia, enquanto na abordagem sistêmica há uma tipologia sistêmica aberta, sem entropia, uma vez que o sistema encontra-se em interação com o ambiente. Com relação às metas, pode-se afirmar que, como consequência do foco nas partes, a abordagem analítica tende à manutenção, enquanto a abordagem sistêmica tende à mudança e ao aprendizado por ser um sistema adaptativo, sempre em busca de um novo equilíbrio. Como consequência, a abordagem analítica tende a ser menos hierárquica, em contraponto com a abordagem sistêmica, que tende a ser mais hierárquica.

Em suma, a abordagem sistêmica é, no dizer de Churchman (1968, p.15), um continuum de percepção e ilusão; uma contínua revisão do mundo, do sistema total e de seus componentes; a essência da abordagem sistêmica é tanto confusão quanto esclarecimento ambos, aspectos inseparáveis da vida humana. Com base nesse continuum percepção-ilusão, Churchman (1968, p.27) sumariza a abordagem sistêmica nos quatro pontos a seguir:

a) a abordagem sistêmica começa quando, pela primeira vez, vê-se o mundo por meio dos olhos de outrem;

b) a abordagem sistêmica apercebe-se continuamente de que toda visão de mundo é terrivelmente restrita. Em outras palavras, cada visão de mundo enxerga apenas uma parte de um sistema maior;

c) não existe ninguém que seja perito na abordagem sistêmica, isto é, o problema da abordagem sistêmica é captar o que todos sabem, algo fora do alcance da visão de qualquer especialista; d) a abordagem sistêmica não é, de todo, uma má ideia.

Cavalcanti e Paula (2006) diferenciam os sistemas na seguinte conformidade: 
Os sistemas podem ser naturais, como os organismos vivos, ou elaborados, como as organizações sociais; podem ser sistemas públicos, como a administração pública, ou privados, como a maioria das empresas; também são encontrados como sistemas isolados, como uma classe escolar, ou abrangentes, como os sistemas que integram e transcendem diversos domínios (sistema de transporte, de água, de educação, econômico, judiciário, político, entre outras inúmeras classificações). (Cavalcanti \& Paula, 2006, p.3)

Para Lieber (2001, p.2), além da condição decorrente da forma de acoplamento, os sistemas classificam-se também conforme gêneros. Podem-se pressupor duas condições extremas, os sistemas naturais (relativos à natureza) e os sistemas sintéticos (relativos ao homem). Para os primeiros poder-se-ia perguntar se a natureza realmente constitui um sistema. Enquanto para os segundos a dúvida é se existe realmente um sistema absolutamente sintético, já que o homem é natural e faz uso da natureza. A resposta a essas questões deve levar em conta que a teoria dos sistemas não compreende objetivo mimético na representação, mas assume-se que o tratamento é arbitrário, como interpretar a natureza como um sistema. Podem-se presumir sistemas sintéticos absolutos quando se consideram a geometria, as equações matemáticas ou um software. Os sistemas sintéticos são plenos de finalidade, ao contrário dos sistemas naturais, pois, a rigor, "no real não falta nada". A natureza é o que é. Mas quando o homem interage com a natureza, ele impõe a esta uma finalidade antes não presente. Coerentemente com uma condição de um "ser de necessidades", "faltas" ou "excessos" vão sendo estabelecidos por ele em pertinência ao um fim presumido. Mas, como o homem também é um "ser de ação", ele se vê coagido a lidar com a natureza nessa pertinência, ou seja, o homem trabalha.

Os sistemas, em relação à sua interação com o meio ambiente, têm sido classificados como fechados ou abertos, embora na realidade nenhum deles se apresente sob essas formas extremas. A viabilização do sistema em cada condição distinta de fronteira decorre das possibilidades dadas pelo processo. Nos sistemas fechados (ou está- 
veis, ou mecânicos) há pouca ou quase nenhuma interação com o meio, ao contrário dos sistemas abertos (ou adaptativos, ou orgânicos). Os sistemas compreendidos como "mecânicos" buscam minimizar a organização (equilíbrio), enquanto os sistemas "orgânicos" buscam a preservação de uma estrutura geneticamente dada dentro de certos limites (homeostase). O sistema cibernético é um tipo particular de sistema aberto. Sua principal característica é a complexidade e a morfogênese (recriação de estruturas). Ou seja, ao contrário dos demais, os sistemas cibernéticos têm características adaptativas, em que a criação, a elaboração e a modificação das estruturas são tidas como pré-requisito para permanecerem viáveis como sistemas operantes (Lieber, 2001, p.3).

Segundo Araújo (1995, p.9), uma das classificações mais empregadas na ciência da informação diz respeito à divisão em sistemas naturais - os existentes na natureza - e sistemas artificiais ou sociais os criados pelo homem para aperfeiçoar os sistemas naturais -, e a autora ressalta que a conotação de sistema social é o de sistema criado pelo homem, e não a de sistema social tal como adotada nas ciências sociais de uma maneira geral, que diz respeito a agrupamentos específicos de indivíduos, conotando "sociedades".

Considerando-se ainda a abordagem sistêmica, há que visualizar as possibilidades metodológicas oferecidas a partir dos referenciais teóricos, uma vez que cada referencial determina a abrangência das propriedades sistêmicas, que podem ser explicadas por meio de seus instrumentos, gerando uma taxonomia dos sistemas.

Segundo Martinelli \& Ventura (2006, p.58), entre as metodologias sistêmicas, existem as metodologias hard e as metodologias soft. Para os autores, as metodologias hard representam a continuidade da influência na teoria dos sistemas das ciências exatas, como a física e a matemática, demandando grande rigor e quantificação, uma vez que se baseiam no paradigma dedutivo e em regras exatas de procedimentos e provas. Normalmente, resultam em modelos descritivos satisfatórios, mas com poucas diretrizes normativas.

Já as metodologias soft consideram o sistema como uma parte percebida ou uma unidade que está apta a manter sua identidade, apesar 
das mudanças ocorridas. Os sistemas soft apresentam estrutura, reagem ao ambiente, alterando as suas funções de curto prazo, e passam por mudanças lentas de longo prazo, mantendo a sua identidade.

Van Gigch (1974, p.38) sistematizou as abrangências de cada metodologia, como pode ser visto no Quadro 2:

Quadro 2-Taxonomia das ciências e sistemas.

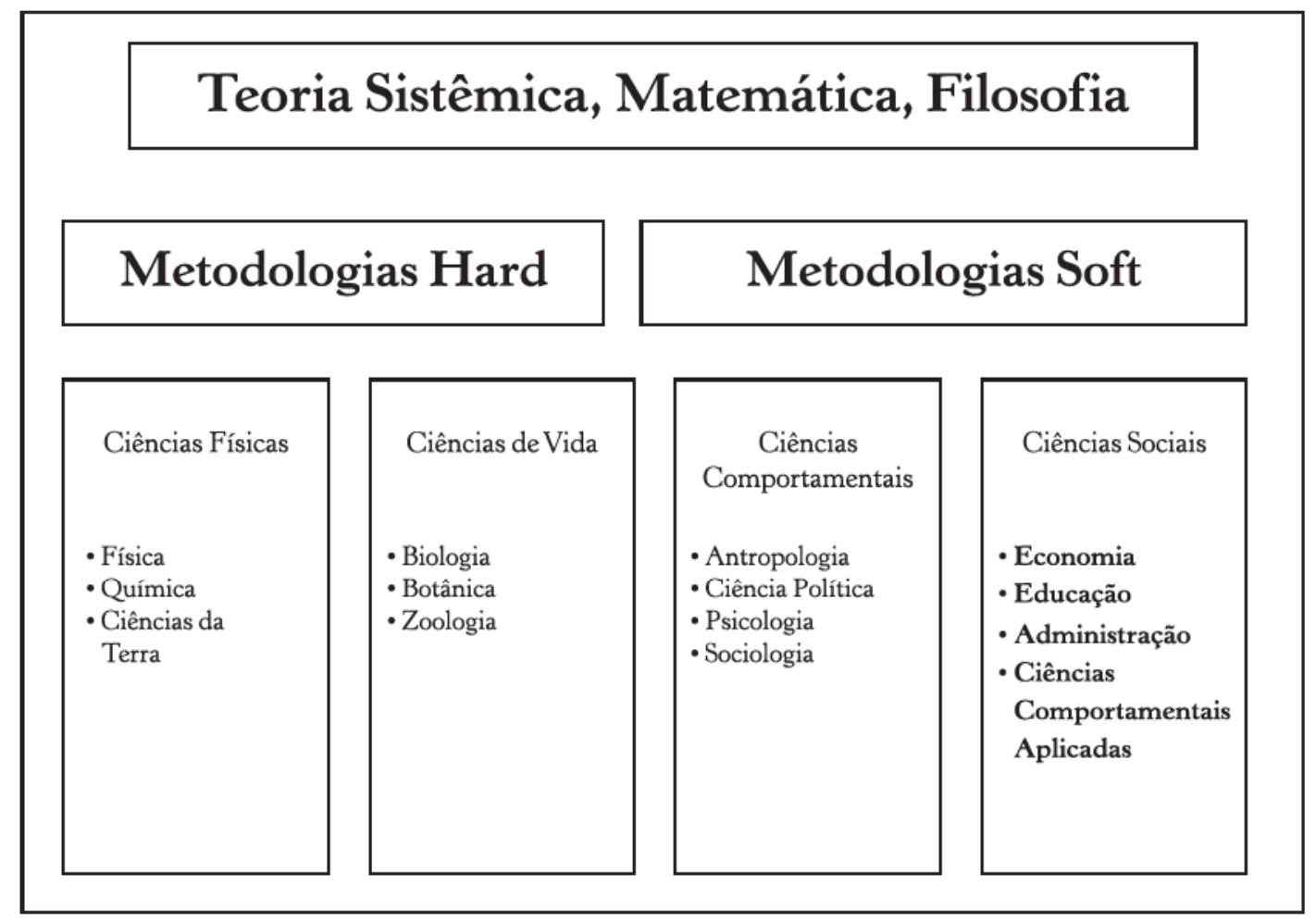

Fonte: Van Gigch (1974, p.38).

A década de 1980 marca o surgimento na literatura (Checkland, 1981) do que se convencionou denominar metodologias da abordagem soft ou, ainda, metodologias para a estruturação de problemas. No entanto, esses métodos, na verdade, passam a ser desenvolvidos a partir da década de 1960 procurando dar conta de situações problemáticas, nas quais a abordagem quantitativa não pode ser aplicada não apenas graças à complexidade ou incerteza existente, mas também por haver a necessidade de se enfatizar os aspectos subjetivos envolvidos em tais situações. 


\section{A Metodologia Sistêmica Soft (SSM): aplicações, benefícios e limitações}

Em uma revisão na literatura, não foram encontrados trabalhos que indiquem quais os casos em que a SSM é de aplicação mais recomendada. Em geral, os estudos apenas enfatizam a conveniência da SSM para situações sociais complexas, nas quais a mensuração e o controle são impraticáveis ou ineficientes.

Para Bellini et al.(2004, p.5), o pouco debate em torno das possíveis aplicações da SSM deve-se ao entendimento de que ela pode servir a qualquer situação problemática, ao contexto organizacional ou à pesquisa social aplicada, e que sua eficácia raramente é afetada por culturas internas ou estilos gerenciais. Entre os usos potenciais, estão a indústria, o setor público e as instituições de filantropia. Também não há estimativas sobre a duração média de uma aplicação da SSM.

Também há poucos registros sobre quais situações a SSM não se mostra eficaz. Além da conclusão imediata de que ela não se presta à operacionalização de soluções, são impróprios ao âmbito da SSM alguns ambientes intransigentes e autocráticos, e sociedades que evitam o confronto de ideias (obstruindo a discussão em grupo) ou em que há alta rotatividade no emprego (prejudicando a implementação, pelos participantes do projeto, das propostas de solução oriundas da SSM). Indica-se ainda que, na tomada de decisão gerencial, a SSM não pode ser usada para a previsão de efeitos de opções estratégicas (ibidem, p.6).

Segundo Checkland (1985), independentemente da aplicação específica da metodologia, seu principal resultado é o aprendizado. Em essência, a SSM favorece o pensamento sistêmico e organiza uma agenda para se discutirem problemas e soluções, mas não produz respostas finais ou resultados fixos. Os benefícios da sua aplicação advêm do processo como um todo, destacando-se os seguintes:

- encoraja-se o analista a considerar questões e temas problemáticos (em vez de problemas específicos); 
- promove-se um melhor entendimento acerca de fraquezas organizacionais e, às vezes, revela-se o porquê de problemas;

- não se impõem soluções tecnológicas ou modismos; e

- exige-se a participação de envolvidos na situação problemática, evitando-se a formulação de políticas alheias à realidade organizacional.

Adicionalmente, há que citar que o debate aberto entre os principais atores de uma situação problemática estimula uma "posse" conjunta das soluções elaboradas, e estas pertencem às pessoas da própria organização.

\section{Os sete estágios de aplicação da SSM}

Nas ciências sociais, a SSM é uma metodologia de gestão essencial para qualquer planejamento, focando os seguintes aspectos:

- exame das percepções do mundo real;

- definição de ações para se atuar no mundo real;

- reflexões sobre os efeitos resultantes das ações tomadas.

Como metodologia soft, a SSM não produz respostas finais a questionamentos (Checkland, 1985) nem acompanha o pesquisador durante as implementações, mas o remete, muitas vezes, a abordagens $h a r d^{3}$ para esses fins. Isso está de acordo com o entendimento de que a SSM não é prescritiva e propõe questões a serem tratadas por outros meios. O questionamento, então, na SSMé algo que nunca termina (ibidem).

3 Os Hard Systems Thinking ignoram a dinâmica dos sistemas ao longo do tempo e cuja sequência de eventos é: reconhecer o problema, definir o problema, identificar as ações para resolvê-lo e o problema resolvido (Checkland, 1981, p.154). 
Checkland (1981) indica sete estágios para a aplicação da SSM, enfatizando suas características de apoio à aprendizagem e à reformulação de hipóteses. Nesse sentido, os aplicadores da SSM devem:

(1) explorar uma situação problemática não estruturada;

(2) expressá-la;

(3) construir definições sucintas de sistemas relevantes;

(4) elaborar modelos conceituais desses sistemas;

(5) comparar os modelos com a situação problemática expressada;

(6) reunir mudanças culturalmente possíveis e sistemicamente desejáveis;

(7) sugerir ações para transformação da situação problemática.

A Figura 2 ilustra os estágios da SSM:

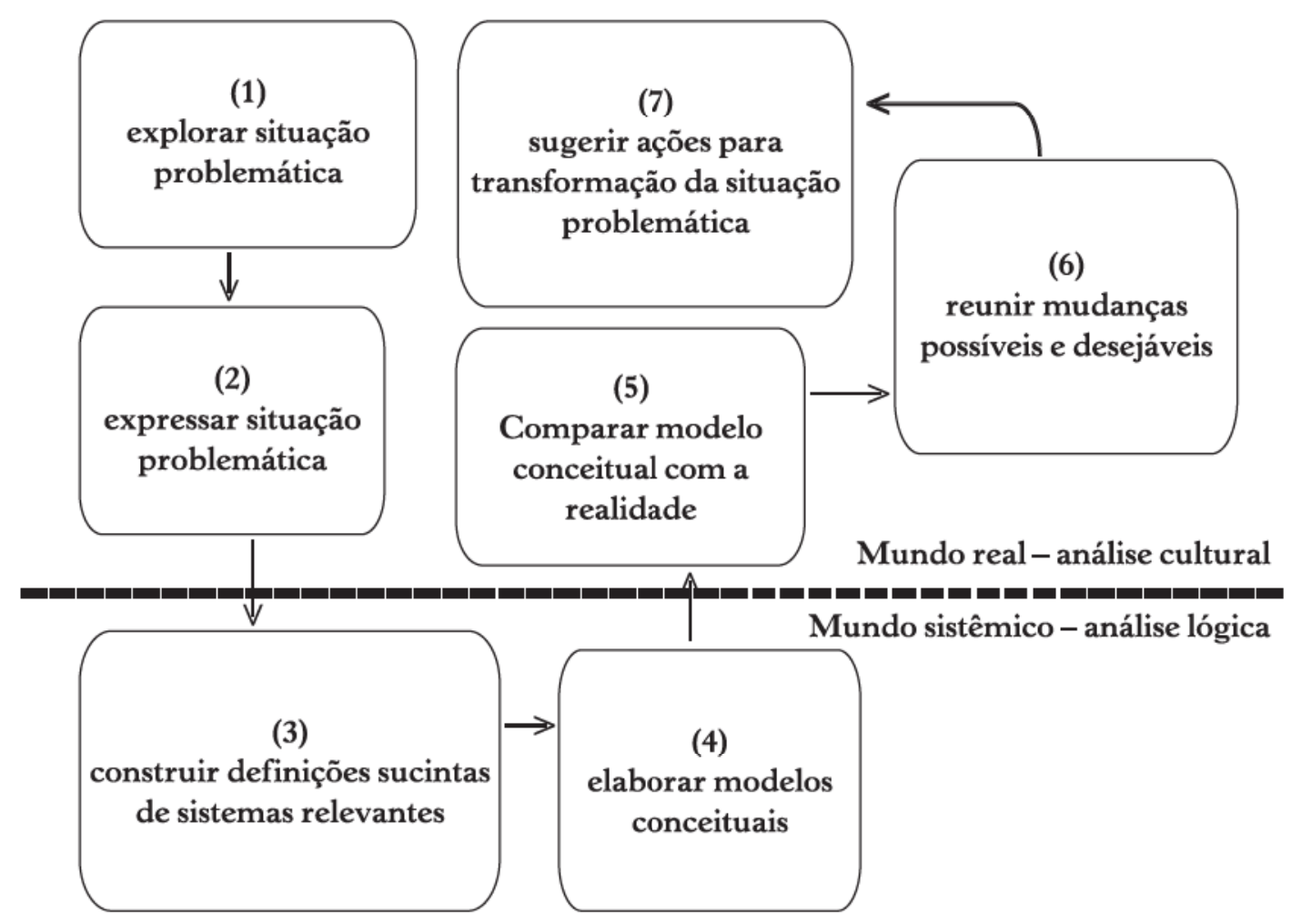

Figura 2 - Estágios da SSM.

Fonte: Checkland (1985). 


\section{Estágios 1 e 2: situação problemática não estruturada e expressa}

Nos dois primeiros estágios, realiza-se um mapeamento da situação problemática, da maneira mais neutra possível. Para tanto, sugere-se que todas as pessoas envolvidas na modelagem (pesquisadores e envolvidos diretos com a situação problemática) elaborem figuras ricas (a nomenclatura é própria da SSM), que são representações gráficas livres com o objetivo de serem evidenciados os entendimentos individuais a respeito de problemas. O uso de gráficos encoraja a formação de ideias e facilita a observação de relações e conflitos, mas não há figuras ricas ou convenções gráficas típicas ou ideais.

Segundo Checkland (1981), os aspectos principais a serem considerados na construção dessas figuras são:

- a estrutura da situação: itens estáticos (como layout físico), hierarquias formais e informais e sistemas de comunicação;

- processo da situação: entendimento de como as coisas funcionam e de quem faz o quê;

- a relação entre estrutura e processo (o "clima" da situação): cultura organizacional.

Checkland (1981) indica que cada ponto de vista dá origem a um sistema relevante (ou assim espera-se que aconteça), constituindo processo que estimula uma busca criativa por opções desejáveis. Tais sistemas servem para entenderem-se os principais aspectos contextuais.

\section{Estágio 3: definições sucintas de sistemas relevantes}

Após o desenho das figuras ricas, discussão a seu respeito e identificação de possíveis sistemas relevantes, aspectos da situação estruturada são colocados em termos sistêmicos: uma descrição básica das atividades, sobre como elas deveriam ser, a partir de um determinado ponto de vista.

Entre os sistemas relevantes identificados, escolhe-se um que tenha maior importância segundo critérios preestabelecidos pelas 
pessoas envolvidas no estudo (pesquisadores e participantes da situação em análise). Desse particular sistema tenta-se extrair uma estrutura fundamental, a definição sucinta, que servirá de base para o seu entendimento sistêmico e para possíveis soluções aceitáveis e desejáveis para a situação problemática (Checkland, 1981).

Checkland (1981) alerta que a elaboração dessa definição sucinta pode não ser trivial para muitas pessoas. $\mathrm{O}$ recurso que auxilia a sua construção é conhecido pelo mnemônico CATWOE, o qual identifica os elementos básicos que nela devem estar presentes:

Quadro 3 - Elementos da CATWOE para definições sucintas de sistemas relevantes.

\begin{tabular}{ll}
$\mathbf{C}$ (customers) - cliente & Vítima ou beneficiário do sistema \\
$\mathbf{A}$ (actors) - ator & Protagonista das atividades \\
$\mathbf{T}$ (transformation process) - transformação & Transformação de entradas em saídas \\
$\mathbf{W}$ (Weltanschauung) - visão de mundo & Contexto \\
$\mathbf{O}$ (owner) - proprietário & Quem tem poder para modificar ou pa- \\
& rar o sistema \\
$\mathbf{E}$ (environmental constraints) - restrições & Restrições do ambiente externo \\
ambientais & \\
\hline
\end{tabular}

Fonte adaptada: Checkland (1981, p.290).

A correta identificação do sistema de atividades requer atenção para definição dos elementos acima. Checkland (1981, p.292) afirma que é muito comum, por exemplo, fazer-se uma definição errônea para customers. Deve-se ter o cuidado de não identificar como clientes do sistema as pessoas que usualmente consumiriam os produtos resultantes de um processo industrial, por exemplo. $O$ correto é definir quais seriam as pessoas responsáveis por levar adiante esse processo. Outro cuidado relevante seria não levantar um número excessivo de aspectos para o que se chama de Weltanschauung e para as transformações (T). Torna-se impossível conceber um modelo com um número excessivo de percepções e/ou transformações, pois o modelo perderia a riqueza adquirida pela possibilidade de, nas definições sucintas de sistemas relevantes, definir o que é o 
sistema, e na construção do modelo conceitual (estágio 4) definir o que precisa ser feito para transformá-lo na situação desejada.

\section{Estágio 4: modelos conceituais}

Os modelos conceituais representam o terceiro dispositivo de modelagem da SSM (os outros dois são as figuras ricas e as definições sucintas), incorporando o que um sistema deve contemplar para estar de acordo com as definições sucintas. Como essa é uma fase do pensamento sistêmico, devem ser considerados processos de monitoramento e controle, além de se prever que o sistema se comunique com o mundo exterior por meio das suas fronteiras. Há que ressaltar, ainda, que os modelos conceituais não são normativos e representam estados desejáveis, não reais.

Checkland (1981), no entanto, alerta para alguns cuidados que se deve ter na formulação de um modelo conceitual. Um dos aspectos mais importantes a levar em consideração, para o qual existe uma grande tendência, é que não se deve conceber o sistema como uma descrição dos sistemas de atividades da realidade presente no mundo real. Isso foge da proposta da abordagem que é de fazer-se uma extrema reflexão selecionando alguns pontos de vista para a situação problemática, os quais seriam possivelmente relevantes para melhorá-la, testando as implicações desses pontos de vista nos modelos conceituais e comparando (no estágio 5) esses modelos com o que existe no mundo real.

Em outras palavras, não se deve procurar descrever uma realidade preexistente quando da construção do modelo conceitual. O que se busca é formular um modelo que, testado sob alguns aspectos julgados relevantes, deve ser um meio para alcançar a realidade desejada. Deve-se buscar construir um sistema de atividades que a torne viável.

Segundo Checkland (1981, p.286), o modelo irá conter um número mínimo de ações necessárias para que o sistema se torne o que foi concisamente descrito na definição de raízes. Essas ações devem ser conectadas de acordo com necessidades lógicas e indicando flu- 
xos essenciais para o primeiro nível de resolução, ou seja, as interconexões entre os subsistemas definidos como raízes.

A seguir serão citadas algumas recomendações básicas que Checkland (1981, p.290) descreve com uma técnica para a construção de um modelo conceitual em seu primeiro nível.

1. A definição da raiz e dos elementos CATWOE forma a impressão do sistema como uma entidade independente que conduz um processo de transformação física e abstrata.

2. Agrupar um pequeno número de ações (verbos) que descrevem as atividades mais fundamentais para o sistema descrito. Devese tentar manter apenas um nível de resolução, evitando a mistura de atividades definidas em diferentes níveis de detalhe.

3. Estruturar as atividades em grupos que tragam consigo atividades semelhantes (grupos que juntos produzem algumas saídas geradas pelo sistema).

4. Conectar as atividades e os grupos de atividades por setas as quais indicam dependências lógicas.

5. Indicar alguns fluxos (concretos ou abstratos) que são essenciais para a expressão do que o sistema faz. É importante distinguir esses fluxos das dependências lógicas feitas no item anterior e tentar indicar um número mínimo de fluxos neste estágio.

6. Verificar se as definições sucintas de sistemas relevantes e o modelo conceitual constituem mutuamente em um par de declarações que definem o que o sistema é e o que o sistema faz.

Se o modelo for elaborado de acordo com essa sequência, ele poderá ser usado como uma fonte para outras versões para modelos do mesmo nível de detalhe como para modelos dos sistemas constituintes. Cada modelo conceitual pode ser expandido em um grupo de modelos que expressam possíveis maneiras de transformação. A validação das modelagens procedidas após a estruturação do modelo básico (no primeiro nível de detalhe) dependerá de como elas estão inseridas no contexto do problema como um todo, não baseado unicamente nas raízes definidas (Checkland, 1981, p.290). 
Logo, deve-se ter uma preocupação em formar grupos de atividades e interconexões lógicas que possibilitem um detalhamento que conduza a um maior conhecimento sobre a situação problemática e ao mesmo tempo facilitem os processos de transformações requeridos para a realidade desejada. Ao passo que se esse procedimento for voltado para o que foi definido nas raízes, o modelo perderá sua função básica que é descrever os meios de transformação.

\section{Estágio 5: modelos conceituais e situação problemática expressa}

Nesse estágio comparam-se os modelos conceituais com o mundo real (Checkland, 1981). É importante serem consideradas, no momento da comparação, as ações e mudanças necessárias para a transformação da situação problemática. Conforme Checkland (1981), quatro são as formas de se efetuar a comparação:

- usando-se o modelo conceitual para apoio à investigação requerida - o modelo conceitual não é mostrado às pessoas envolvidas na situação que está sendo modelada, e o analista o utiliza como forma de facilitar o debate sobre a mudança;

- trilhando-se o modelo conceitual com sequências de eventos passados - investigação de como os eventos teriam ocorrido se o modelo conceitual tivesse existido anteriormente, e comparação com a prática (um problema associado é a seletividade da memória das pessoas envolvidas);

- discutindo-se o modelo conceitual com os atores principais da situação (o analista necessita de tempo para explicar as características do modelo conceitual aos envolvidos);

- sobrepondo-se modelos - comparação do modelo conceitual com a realidade, quando se identifica a presença, ou não, das atividades do modelo conceitual no mundo real. 


\section{Estágios 6 e 7: mudanças possíveis e desejadas e ações para transformação}

Nos dois últimos estágios, elaboram-se recomendações de mudança, mas a solução para uma situação problemática nem sempre pode ser obtida com metodologia soft; de fato, pode-se requerer o uso de alguma abordagem hard para isso. O principal resultado obtido pela perspectiva soft é, já dito, a aprendizagem.

De modo geral, alternativas de ação são recomendadas ao final do estudo. Também podem ser esperadas mudanças nos aspectos tratados pelas duas primeiras fases: a estrutura (forma como as pessoas são organizadas e controladas), o processo (modo como as pessoas trabalham e suas interações neste particular) e o clima (atitudes das pessoas com relação ao trabalho, clientes etc.).

\section{Considerações finais}

A SSM foi selecionada como metodologia de trabalho por sua capacidade de lidar com situações bastante complexas, nas quais não exista consenso acerca do problema; ou seja, são conhecidas as consequências, mas não se sabe exatamente o que fazer para que o sistema em foco atinja seus objetivos. Além disso, a SSM está consolidada em círculos acadêmicos como a mais desenvolvida abordagem soft e um importante veículo para pesquisa qualitativa.

A SSM é uma metodologia, e não técnica, para a articulação de problemas pouco estruturados. Entre os motivos para essa escolha, destaca-se a sua proeminência na literatura acadêmica sobre realidades complexas (Ranyard, 2000; Rose, 1997). A sua aplicação se fundamenta em uma ampla interação entre facilitadores e pessoas envolvidas nas situações em estudo, pois o que se busca é o aprendizado, a acomodação de múltiplos interesses e visões, no presente caso, voltadas à geração do conhecimento. De fato, ela objetiva o consenso a partir da participação de pessoas de todos os níveis organizacionais. 
Utiliza-se a SSM por permitir a adoção de uma abordagem global do problema a ser abordada, sendo aplicável com elevado nível de abstração e de resolução aos complexos estudos no campo social.

Segundo Bellini et al. (2004, p.4), a sua aplicação se fundamenta em uma ampla interação entre facilitadores e pessoas envolvidas nas situações em estudo, pois o que se busca é o aprendizado, a acomodação de múltiplos interesses e visões, no presente caso, voltadas à geração do conhecimento. De fato, ela objetiva o consenso a partir da participação de pessoas de todos os níveis organizacionais.

Dessa forma, pode-se afirmar que a SSM contempla os objetivos dos estudos da gestão do conhecimento nas organizações, uma vez que essa lida com situações subjetivas e complexas, e apenas uma abordagem quantitativa não parece ser capaz de apresentar resultados em sua totalidade.

Como visto anteriormente, os modelos conceituais extraídos da SSM não são normativos e representam estados desejáveis, não reais, podendo, dessa forma, ser aplicados a uma gama variada de organizações nas quais se pretende centrar a gestão do conhecimento nas pessoas e na cultura organizacional.

\section{Referências}

ARAUJO, V. M. R. H. Sistemas de informação: nova abordagem teórico-conceitual. Ciência da Informação, Brasília, v.24, n.1, 1995.

BELLINI, C. G. P. et al. Soft systems methodology: uma aplicação no "Pão dos Pobres" de Porto Alegre. RAE-Eletrônica, São Paulo, v.3, n.1, Art.3, jan./jun. 2004.

BERTALANFFY, L. von et al. Teoria dos sistemas. Rio de Janeiro: Editora FGV, 1976.

CAVALCANTI, M. F.; PAULA, V. A. F. Teoria geral de sistemas I. In: MARTINELLI, D. P.; VENTURA, C. A. A. (Org.) Visão sistêmica e administração: conceitos, metodologias e aplicações. São Paulo: Saraiva, 2006. p.1-14.

CHECKLAND, P. Systems thinking, systems practice. Chichester: Wiley, 1981. 
From optimizing to learning: a development of systems thinking for the 1990s. Journal of the Operational Research Society, v.36, n.9, p.757-67, 1985.

CHOO, C. W. A organização do conhecimento: como as organizações usam a informação para criar significado, construir conhecimento e tomar decisões. São Paulo: Editora Senac, 2003.

CHURCHMAN, C. W. The systems approach. New York: Dell Publishers, 1968.

DAVENPORT, T. H. Dominando a gestão da informação. Porto Alegre: Bookman, 2004.

LIEBER, R. R. Teoria de sistemas. 2001. Disponível em: <http:// www.prolides.org.br/filemanager/download / 4 / teoria\%20de\%20sistema.pdf>. Acesso em: dez. 2009.

MARTINELLI, D. P.; VENTURA, C. A. Metodologias sistêmicas I. In: MARTINELLI, D. P.; VENTURA, C. A. A. (Org.) Visão sistêmica e administração: conceitos, metodologias e aplicações. São Paulo: Saraiva, 2006. p.53-72

MORAES, C. R. B.; FADEL, B. Ambiência organizacional, gestão da informação e tecnologia. In: VALENTIM, M. L. P. (Org.) Informação, conhecimento e inteligência organizacional. Marília: Fundepe Editora, 2006. p.99-114.

NONAKA, I.; TOYAMA, R. Criação do conhecimento como processo sintetizador. In: TAKEUCHI, H.; NONAKA, I. (Org.) Gestão do conhecimento. Porto Alegre: Bookman, 2008. p.91-117.

PÉREZ MONTORO GUTIÉRREZ, M. Gestión del conocimiento en las organizaciones. Gijón: Trea, 2008.

PONJUÁN DANTE, G. Gestión de información: dimensiones e implementación para el éxito organizacional. Gijón: Trea, 2007.

PRUSSAK, L. Tornando visível o conhecimento. In: DAVENPORT, T. et al. (Org.) Dominando a gestão da informação. Porto Alegre: Bookman, 2004. p.208-13.

RANYARD, J. C. Commentary on Checkland (1985): achieving "desirable and feasible" change: an application of soft systems methodology. Journal of the Operational Research Society, v.51, n.1, p.1347-8, 2000.

RAPOPORT, A. Aspectos matemáticos da análise geral dos sistemas. In: BERTALANFFY, L. von et al. (Org.) Teoria dos sistemas. Rio de Janeiro: Editora FGV, 1976. p.21-46. 
ROSE, J. Soft systems methodology as a social science research tool. Systems Research and Behavioral Science, v.14, n.4, p.249-58, 1997.

SCHEIN, E. H. Organizational culture and leadership: a dynamic view. San Francisco: Jossey Bass, 1992.

SCHODERBEK, P. et al. Management systems: conceptual considerations. Boston: Irwin, 1990.

TAKEUCHI, H.; NONAKA, I. Gestão do conhecimento. Porto Alegre: Bookman, 2008.

VAN GIGCH, J. P. Applied general system theory. New York: Harper \& Row, 1974. 



\section{3 \\ EstRATÉGIAS DE PRESERVAÇÃo DIGITAL \\ José Carlos Abbud Grácio \\ Bárbara Fadel}

\section{Introdução}

Com a invenção dos computadores, o surgimento da internet, a globalização e as constantes mudanças e avanços nas Tecnologias de Informação e Comunicação (TIC), a sociedade atual passou e tem passado por diversas mudanças com relação à forma como as informações têm sido tratadas. A informação que antes estava registrada em grande parte em papel, passou a ser produzida e registrada em formato digital.

Essas mudanças e avanços nas TIC trouxeram também uma mudança de cultura nas organizações e nos indivíduos, que passaram a ter acesso a maior quantidade de informações e de maneira muito mais rápida, ou seja, em tempo real e mais interativo, mudando assim a relação de tempo e espaço entre a informação e o usuário. Nesse contexto, surge a necessidade de tratar um novo tipo de informação, a informação digital.

Para Barreto (1999, p.168), a informação pode ser definida como "conjuntos significantes com a competência e a intenção de gerar conhecimento no indivíduo, em seu grupo e na sociedade", conhecimento esse que tem como objetivo promover o desenvolvimento do indivíduo e da sociedade em que ele vive. 
Para Dahlberg (1995), o conhecimento é algo que pode ser adquirido por alguém pelo seu próprio repensar, com as informações de que ele dispõe como um processo individual, não podendo ser transferido.

Para que a informação possa gerar conhecimento em um indivíduo ela necessita chegar até ele, ou seja, necessita circular e ser transmitida em um intervalo de tempo aceitável e em um formato compreensível. Mas para chegar até o indivíduo, a informação necessita estar registrada, documentada e armazenada.

Se a informação tem como objetivo gerar conhecimento no indivíduo, em seu grupo e na sociedade, a informação digital poder ser definida como um tipo de informação, com os mesmos objetivos, mas cuja especificidade se refere a suas formas de produção, organização, administração, distribuição, acesso e preservação, bem como quanto aos suportes de armazenamento.

Ferreira (2006) denomina as informações armazenadas em meio digital como objetos digitais, que podem ser definidas como todo e qualquer objeto de informação que possa ser representado mediante uma sequência de dígitos binários, como textos científicos, bancos de dados, fotos digitais, vídeos, páginas Web, software etc.

Uma informação, disponível em um documento digital, pode estar presente em diversos objetos digitais, armazenados em suportes diversos e acessíveis por diversas formas. Essa diversidade nas formas de suporte e acesso é uma das principais diferenças da uma informação disponível em meio digital para uma informação armazenada em meio analógico como o papel.

Ao mesmo tempo que as novas TIC estão mudando os conceitos de documentos e seus registros, no que tange à informação digital, esses documentos registrados em meio digital são mais frágeis que o papel e correm risco maior de perda ao longo do tempo. Essas informações contêm um valor histórico para muitos governos, instituições e pessoas, e se não forem tratadas e preservadas adequadamente serão perdidas para as gerações futuras (Rothenberg, 1999, p.1).

Surgida no final do século XX, a informação digital possibilitou um grande desenvolvimento na sociedade atual, gerando novas pos- 
sibilidades e grandes avanços. Mas, como toda nova tecnologia, deixou também algumas ameaças e desafios a serem enfrentados. Entre eles, podemos citar:

- mudanças e avanços muito rápidos nas tecnologias de acesso à informação digital, causados especialmente pelo surgimento da internet;

- obsolescência do hardware e do software, que com os avanços tecnológicos se tornam ultrapassados muito rapidamente;

- a explosão da quantidade de informação armazenada em meio digital, que cresce a cada dia, substituindo os meios de armazenamento tradicionais;

- as mudanças no formato dos arquivos e das mídias de armazenamento;

- custo elevado das novas tecnologias.

Essas ameaças e desafios afetam tanto os documentos que já nascem no formato digital como também os documentos que, apesar de nascerem no formato analógico, são transformados no formato digital, com o objetivo de permitir maior circulação e acesso a eles.

Os avanços do hardware, sejam por questões de avanço tecnológico, sejam por interesses comerciais, também levam a mudanças no software utilizado, nos suportes de armazenamento e, consequentemente, na forma como a informação digital é tratada, armazenada e acessada.

A evolução do software tem trazido uma descontinuidade muito rápida dos programas, gerando a necessidade da criação de mecanismos que garantam o acesso aos arquivos criados em versões anteriores.

No caso dos suportes de armazenamento digital, como disquetes, CD, DVD, pen-drive e outros, o problema é o mesmo, ou seja, a decadência física desses suportes. Muitos microcomputadores já não são produzidos com dispositivo de leitura para alguns desses suportes. Além da descontinuidade desses dispositivos de leitura, temos também o problema da deteriorização dos suportes, causados pelo 
tempo de vida (durabilidade), e por danos decorrentes de fatores externos, como temperatura, umidade, qualidade do suporte e outros.

Outro fator determinante de obsolescência é a perda de informações referentes ao formato de um arquivo digital, sua codificação e até mesmo sobre a compressão dos arquivos, pois, mesmo tendo hardware, software e suporte adequado, não será possível a recuperação da informação digital se não tivermos os dados referentes ao formato de armazenamento.

Essa obsolescência tecnológica nos leva à necessidade de se buscar soluções para a recuperação, no futuro, dessas informações armazenadas em meio digital. Nesse contexto, surge a necessidade da preservação de um novo tipo de patrimônio, a informação digital, armazenada nos computadores e nos suportes digitais, e com ela uma nova área de pesquisa, a preservação digital.

Pesquisas têm demonstrado uma preocupação cada vez maior das instituições com o problema da preservação e do arquivamento digital, mas também mostra que a maioria dessas instituições ainda não tem planos de ações efetivas para tratar o problema (National..., 2006).

Para Arellano (2004, p.16), "o desafio é muito mais um problema social e institucional do que um problema técnico, porque, principalmente para a preservação digital, depende-se de instituições que passam por mudanças de direção, missão, administração e fontes de financiamento".

Podemos observar uma dependência social da informação, e atualmente mais ainda da informação digital, que pelos meios atuais de comunicação, como o computador e a internet, chegam às pessoas de maneira mais rápida e acessível, criando na sociedade atual uma dependência dessa informação disponível em meio digital.

Arellano (2008, p.24) afirma que "a preservação da informação em formato digital precisa de um conjunto de práticas técnicas e de gerenciamento que mudam constantemente", em razão de estarem inseridas nas TIC, que também evoluem e mudam de maneira muito rápida. Observa que atualmente existe "pouca avaliação dos fun- 
damentos teóricos e metodológicos das estratégias de preservação digital".

\section{Preservação digital}

Segundo Ferreira (2006), a preservação digital é definida como a capacidade de garantir que a informação digital permaneça acessível e com qualidade de autenticidade para que possa, no futuro, ser interpretada numa plataforma tecnológica diferente daquela utilizada em sua criação. $\mathrm{O}$ conceito de autenticidade pode ser entendido como a capacidade de identificar elementos que permitam definir se um objeto é autêntico ou não.

Arellano (2004, p.17) define a preservação digital como mecanismos que permitem o armazenamento em repositórios de dados digitais, garantindo a perenidade dos seus conteúdos e integrando a preservação física, lógica e intelectual dos objetos digitais.

A National Library of Australia (2008) define a preservação digital como "o processo envolvido na manutenção e, se necessário, no restabelecimento da acessibilidade para os recursos de informação digital".

Podemos observar que, apesar de as definições serem diferentes, os objetivos são os mesmos, ou seja, garantir que a informação digital a ser preservada possa ser recuperada ao longo do tempo, apesar das mudanças constantes nas TIC e na gestão das instituições.

A preservação digital pode, portanto, ser definida como um conjunto de propriedades e ações com o objetivo de garantir o acesso, no futuro, à informação digital numa plataforma tecnológica diferente daquela utilizada em sua criação.

A preservação digital pode ser inserida em três requisitos (Arellano, 2004, p.17):

- preservação física: relacionada aos conteúdos armazenados nos meios de armazenamento ou suportes, tais como CD-ROM, DVD etc. 
- preservação lógica: relacionada aos novos formatos para a inserção de dados, novos softwares e hardwares. Compreende atividades de conversão dos formatos originais em novos formatos, pela questão da obsolescência.

- preservação intelectual: compreende mecanismos que garantam a integridade e a autenticidade. Diferentemente do documento impresso, o documento digital é passível de modificação e, portanto, pode perder sua propriedade intelectual. A preservação da propriedade intelectual é uma das barreiras que interferem na preservação de objetos digitais, pois esses são passíveis de modificação durante as atividades de preservação.

A preservação digital pode significar num primeiro momento a necessidade de criar condições técnicas para recuperar ao longo do tempo um objeto digital. Entretanto, podemos observar que o desafio técnico tem soluções mais palpáveis do que o desafio da conscientização dos usuários e das instituições da necessidade de se desenvolver ações de preservação digital. Isso ocorre em razão da falta de cultura de preservação, até pela curta existência das informações armazenadas em meio digital.

Vários são os aspectos que envolvem a preservação digital, e a definição de políticas de preservação digital é necessária para a definição de como esses aspectos deverão ser tratados.

A política de preservação digital deve ter como objetivo garantir que as instituições tenham um planejamento e estratégias bem definidas para o armazenamento e uso de recursos de informação digital para longos períodos de tempo. Essa política deve garantir a continuidade do processo de preservação digital.

Ferreira (2006) aponta que uma política de preservação digital deve envolver todos os aspectos de um objeto digital, como criação de uma política de avaliação e seleção do material, definição de metainformação, estratégias para cada classe de objeto, política de continuidade, financiamento sustentável, objetivos em nível social e organizacional, entre outros. 
Da mesma forma que as TIC não são estáticas e sofrem constantes mudanças, uma política de preservação digital que trate desses aspectos também deverá ser revista periodicamente para atender às necessidades da instituição diante desses avanços.

\section{Aspectos da preservação digital}

Um dos aspectos importantes que envolvem a preservação digital são as estratégias de preservação que deverão ser adotadas para cada tipo de objeto digital. Mas, além das estratégias, outros aspectos importantes estão envolvidos na preservação digital. Entre eles, podemos citar:

\section{Objetivos da instituição}

Qualquer política de preservação digital deve estar alinhada com os objetivos da instituição, pois a partir disso é possível definir quais os tipos de informação institucional serão preservados. A partir da definição dos tipos de informação digital a serem preservados é possível definir os princípios a serem adotados na instituição para as atividades de preservação digital, princípios esses que devem seguir leis federais, estaduais e municipais, além de legislações próprias da instituição.

\section{Seleção}

A seleção consiste em definir o que deve ser preservado, ou seja, selecionar as informações digitais a serem preservadas de acordo com os objetivos da instituição. Dependendo do tamanho da instituição, fica inviável preservar toda informação digital produzida.

A definição de prioridades referente ao que deve ser preservado é desejável juntamente com o processo de seleção, pois as atividades de preservação digital podem sofrer atrasos ou restrições, em razão do grande volume de informações. 


\section{Modelos, padrões e iniciativas}

Segundo Arellano (2008, p.54), as iniciativas mundiais de preservação digital indicam a necessidade de utilização de padrões já estabelecidos e também indicam a utilização de documentos em formatos abertos, pois esses permitem seu entendimento para as gerações futuras, facilitando a conversão para novos formatos, diante das mudanças nas TIC.

A adoção de padrões e modelos já utilizados e testados por instituições que trabalham com a preservação digital permite garantir maior possibilidade de continuidade do padrão adotado e a possibilidade da troca de informações entre instituições (interoperabilidade). O Open Archival Information Systems (OAIS), desenvolvido pelo Consultative Committee for Space Data Systems (CCSDS) é atualmente um dos modelos mais recomendados, por ser uma norma International Organization for Standardization (ISO), número 14.721, de 2002, e descrever um enquadramento conceitual para um repositório digital genérico, com garantias de confiabilidade.

\section{Responsabilidades}

É consenso na literatura que a preservação digital é responsabilidade tanto do criador do objeto digital como da instituição na qual esse objeto está disponível. A instituição deve definir claramente as atividades de preservação e os responsáveis por cada uma delas, sendo dessa forma reconhecida como uma instituição comprometida com as atividades de preservação. Essa definição das responsabilidades ajuda a garantir a autenticidade do objeto digital a ser preservado.

\section{Recursos financeiros}

A preservação digital, por estar envolvida com as mudanças e avanços nas TIC, é uma atividade cara, que requer disponibilidade de recursos financeiros, pois envolve investimentos permanentes em tecnologia, infraestrutura e capacitação de pessoal. 
Isso torna necessário que as instituições possuam uma política permanente de investimento, com os custos da preservação fazendo parte do orçamento e garantindo as atualizações necessárias dos equipamentos e do software, a capacitação da equipe de trabalho, os investimentos em infraestrutura e a avaliação constante nos procedimentos de preservação. Dessa forma, mesmo com as mudanças que podem ocorrer na administração da instituição, o processo de preservação permanece como uma das prioridades da instituição.

\section{Autenticidade}

O contexto digital, diferentemente do analógico, oferece ferramentas de software e de hardware que possibilitam facilmente realizar alterações em documentos digitais. Ao mesmo tempo que essas ferramentas facilitam algumas atividades, torna-se um fator de risco quando tratamos da preservação desse documento digital, uma vez que exige tratamento adequado que garanta sua autenticidade ao longo do tempo.

Para isso, é importante a definição das propriedades desse objeto digital que deverão ser mantidas e preservadas para que o mesmo possa ser considerado autêntico, influenciando também diretamente na forma como esse deverá ser preservado (Ferreira, 2006).

Uma instituição com objetivos e políticas claras de preservação contribui para que os objetos digitais a serem preservados tenham uma garantia maior de autenticidade.

\section{Metadados}

Comumente chamado de dados sobre dados, o termo metadados pode ser mais bem descrito como um conjunto de dados, chamados de elementos, cujo número é variável, de acordo com o padrão adotado, e que descreve o conteúdo de um recurso, possibilitando a um usuário ou a um mecanismo de busca acessar e recuperar esse recurso. Também possibilita ao profissional da informação tratar de forma mais adequada esse recurso. Esses elementos 
descrevem informações como nome, descrição, localização, formato, entre outras.

A utilização de metadados tem como objetivo descrever e documentar o objeto digital detalhadamente, permitindo armazenar informações do tipo proveniência, autenticidade, formato, ambiente tecnológico e outras informações. Gilliland-Swetland (1998) divide os metadados em cinco tipos, de acordo com os aspectos de sua funcionalidade em um sistema digital:

- Administrativos: metadados usados no gerenciamento e administração dos recursos informacionais.

- Descritivos: metadados usados para descrever e identificar informações sobre recursos.

- Conservação: metadados relacionados à conservação de recursos de informação, ou seja, que representam ações tomadas para a preservação de um recurso informacional, digital ou não, tal como indicação de condições físicas do documento, ou indicação de migração.

- Técnicos: metadados relacionados ao funcionamento do sistema e comportamento dos metadados.

- Uso: metadados relacionados com o nível e tipo de uso dos recursos informacionais.

Para Saramago (2003), os metadados para preservação são definidos como "informação de apoio aos processos associados com a preservação digital de longo prazo" e podem ser divididos em três tipos:

- Descritivos: descrevem o recurso.

- Administrativos: documentam os atos de gestão ao longo do tempo para a preservação do recurso.

- Estruturais: complementam os metadados administrativos, pois acrescentam as informações tecnológicas para a preservação do recurso. 
Nessa divisão, os metadados administrativos e os estruturais contêm as descrições dos métodos e estratégias aplicados para a preservação digital dos recursos.

Atualmente, cremos que metadados poderiam ser mais adequadamente definidos como um conjunto de elementos que descrevem as informações contidas em um objeto digital, com o objetivo de possibilitar sua busca, recuperação e preservação.

\section{Aspectos legais}

Dependendo do objeto digital a ser preservado, é necessário que a instituição disponha de conhecimento da legislação vigente com o objetivo de saber o que pode ser preservado, o que deve sê-lo e como fazê-lo, sem descumprir as leis existentes. Isso também é um aspecto que dá credibilidade à instituição.

\section{Direito autoral}

Gandelman (2001, p.28) considera o direito autoral um dos ramos da ciência jurídica que lidam com a imaterialidade, uma característica da propriedade intelectual. Com o desenvolvimento das TIC, surge também a necessidade da evolução da proteção jurídica das obras intelectuais produzidas em formato digital.

No contexto dos ambientes digitais, o direito autoral surge com um tema contemporâneo e estratégico, especialmente quando relacionado à informação armazenada em meio digital.

Com as ferramentas de software e de hardware, um documento no formato digital pode ser alterado de maneira simples e, dependendo do tipo de documento, como um artigo científico, isso se torna um problema, pois essa alteração pode gerar um problema de quebra dos direitos autorais do autor, comprometendo a instituição responsável em preservar esse documento digital.

No caso da internet e dos documentos postados e disponíveis nela, o problema dos direitos autorais é ainda mais complexo, pois ela tem uma rápida expansão por não possuir regras ou normas para a 
postagem de informação. Com essa evolução e crescimento, agora começa a se discutir a questão dos direitos do autor nas informações disponíveis na internet.

Como a preservação digital implica muitas vezes reproduzir o objeto digital, o problema dos direitos é um aspecto importante, pois o material original é protegido pelas leis de direito autoral. Portanto, qualquer estratégia deve estar amparada em leis que respaldem a instituição e garantam ao autor do objeto digital a sua propriedade intelectual.

\section{Infraestrutura tecnológica}

A infraestrutura tecnológica é fundamental para atender adequadamente a cada fase da vida de um objeto digital e garantir que o mesmo esteja disponível para busca, recuperação e acesso. Essa infraestrutura tem que garantir ao objeto digital que está sendo preservado, especialmente, sua integridade, segurança, o correto armazenamento, políticas de backup e prevenção/recuperação de desastres.

Nesse sentido, a capacitação permanente dos profissionais responsáveis por essas atividades é fundamental, pois, da mesma forma que as TIC, a infraestrutura passa por constantes avanços e consequentemente pela necessidade de readequação a essas novas tecnologias.

\section{Repositórios digitais}

O desenvolvimento de repositórios digitais emergiu como uma nova estratégia de gerenciamento e divulgação da produção científica no começo do século XXI. Com o aumento da quantidade de material digital nas universidades e o surgimento de software (livre ou proprietário) de tratamento dessa informação, a implementação de repositórios digitais nas universidades passou a ser uma ferramenta importante para a divulgação da produção científica.

Ferreira (2006) aponta que, atualmente, os principais repositórios digitais (DSpace, Fedora e Eprints) não proporcionam adequada- 
mente a implementação de políticas de preservação nem esquemas de metainformação, mas oferecem capacidade de armazenamento, organização, descrição e disseminação do material armazenado, possibilitando assim, em curto prazo, a incorporação de funcionalidades de preservação.

\section{Equipe multidisciplinar}

Como o tratamento da informação digital a ser preservado envolve aspectos legais, técnicos e administrativos, é necessário que as instituições disponham de profissionais de várias áreas para o tratamento desse tipo de informação. Dessa forma surge a necessidade da criação de uma equipe multidisciplinar, com competências diversas para gerenciar as atividades de preservação digital. Essa equipe deverá ser composta por bibliotecários, arquivistas, profissionais das áreas de ciência da informação, informática, sistemas de informação, direito, administração, engenharia, docentes (no caso das instituições de ensino) e outros que a instituição julgar necessários.

\section{Suporte}

Os suportes são meios de armazenamento que possuem uma vida útil e, portanto, necessitam de controle para que sejam realizadas periodicamente atividades de substituição desses suportes por outros mais atuais, além do controle de variáveis ambientais (tempo de uso do suporte, temperatura, umidade, qualidade do suporte, manipulação, homem) que minimizem riscos de deteriorização precoce do suporte de armazenamento.

\section{Estratégias de preservação}

Um aspecto importante a ser discutido na questão da preservação digital é determinar qual a melhor estratégia a ser aplicada para cada tipo de objeto digital a ser preservado e, nesse sentido, torna-se 
necessário definir se o objeto de preservação deve ser o objeto físico original ou a conservação do conteúdo embutido nesse objeto.

Arellano (2004, p.18) aponta que os principais métodos recomendados para a preservação digital podem ser agrupados em dois tipos:

- Estruturais: trata dos investimentos iniciais das instituições para implementação da preservação digital, tais como adoção de padrões, elaboração de normas, definição dos metadados de preservação, montagem da infraestrutura e formação de consórcios.

- Operacionais: são as medidas concretas aplicadas aos objetos digitais, tais como as estratégias de preservação e a conservação do software/hardware.

Thibodeau apud Ferreira (2006, p.31) organiza em um mapa as diferentes estratégias de preservação, e no eixo horizontal é posicionado no seu extremo esquerdo as estratégias centradas na preservação do objeto físico e no extremo direito as estratégias centradas na preservação do objeto conceitual. No eixo vertical, que indica o nível de especificidade das estratégias, a parte inferior dispõe sobre as estratégias apenas aplicáveis a uma dada classe de objetos digitais e a parte superior dispõe sobre as estratégias genéricas, aplicáveis a qualquer classe de objetos digitais (Figura 1).

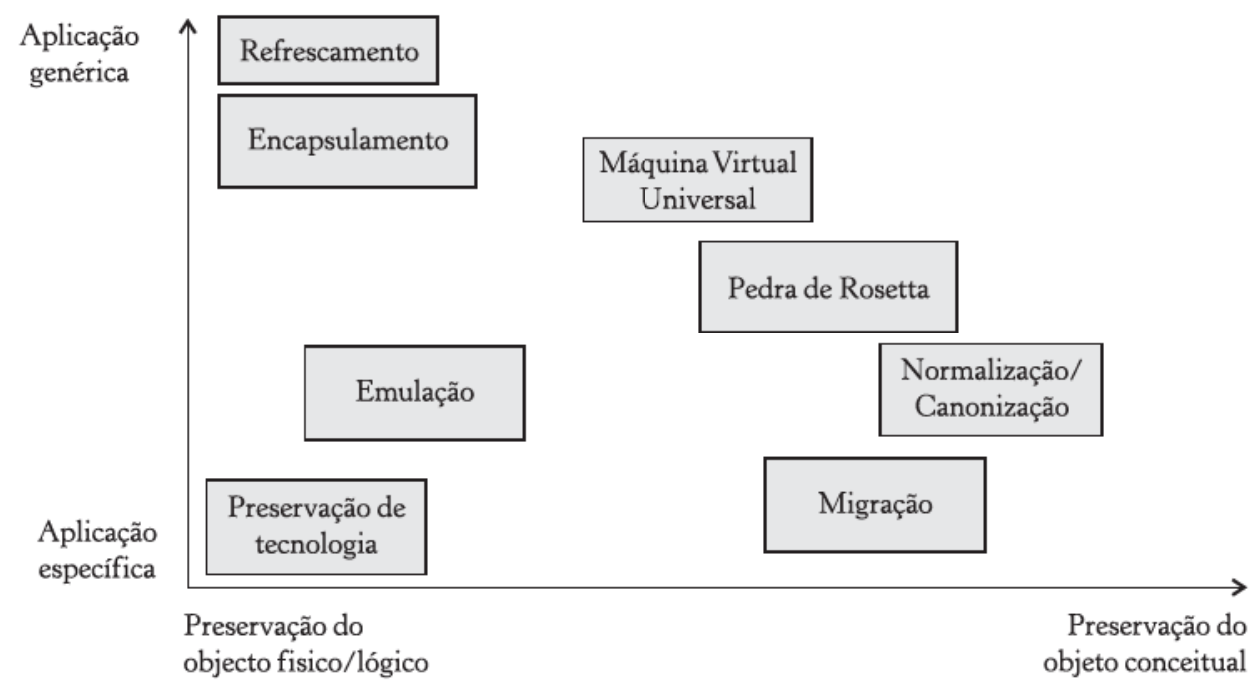

Figura 1 - Classificação das estratégias de preservação.

Fonte: Thibodeau apud Ferreira (2006). 
Com relação às estratégias de preservação, podemos definir dois tipos de conservação (Ferreira, 2006): a conservação do objeto digital no seu formato original e a conservação do conteúdo intelectual do objeto digital.

\section{Conservação do objeto digital no seu formato original}

Essas estratégias consistem em preservar o objeto digital na sua forma original, sem alterar sua estrutura. Podemos citar três estratégias distintas, conforme será apresentado.

\section{Preservação de tecnologia}

Consiste em preservar o ambiente tecnológico utilizado na concepção do objeto digital e tem como objetivo conservar todo hardware e software necessários para o acesso à informação preservada. Esse tipo de estratégia trata da criação de museus de tecnologia, nos quais o foco da preservação não se concentra no objeto conceitual, mas, sim, na preservação do objeto digital original. Alguns pesquisadores consideram esse tipo de estratégia como a única forma eficaz de assegurar que os objetos digitais sejam preservados de forma fidedigna (Ferreira, 2006, p.32).

Com os constantes avanços das TIC, sobretudo do hardware e do software utilizados, esse tipo de preservação, entretanto, apresenta problemas, pois é inevitável que qualquer plataforma tecnológica, mesmo a mais popular, acabe se tornando obsoleta e deixando de existir. Dessa forma não será possível no futuro recuperar a informação digital preservada. Mesmo as instituições que consigam manter a plataforma tecnológica suficiente para preservar o objeto digital provavelmente terão problemas com relação à disponibilização dessa informação em plataformas mais atuais e com novas tecnologias, ficando restrito a um grupo de usuários o acesso ao objeto digital. 


\section{Refrescamento}

O refrescamento consiste em transferir a informação digital de um suporte físico de armazenamento para outro mais atual, antes que o primeiro deteriore (Ferreira, 2006, p.33).

A necessidade de se aplicar a técnica de refrescamento nos documentos digitais para sua preservação é análoga aos textos em papel, que podem ser preservados por meio da cópia de seu texto original, que preserva o conteúdo e o formato original do texto em papel, ou por meio da transcrição para outra língua, mesmo que essa técnica possa implicar a perda de alguma informação (Rothenberg, 1999, p.11).

Estudos demonstram que o suporte físico se deteriora ao longo do tempo, pois está sujeito a diversos fatores que contribuem para a perda de sua capacidade de armazenamento. Além disso, os periféricos que dão acesso a esse suporte deixam de existir muito rapidamente em razão dos avanços das TIC. Portanto, além da necessidade de conhecer o tempo de vida de um suporte, é necessário também verificar periodicamente a integridade desse suporte, mediante atividades periódicas de verificação. A dificuldade nesse tipo de estratégia é garantir que o hardware necessário para leitura do suporte de armazenamento permaneça confiável ao longo do tempo, mesmo após o mesmo deixar de ser produzido.

\section{Emulação}

Ferreira (2006, p.33) define a emulação como a "utilização de um software, designado emulador, capaz de reproduzir o comportamento de uma plataforma de hardware e/ou software, numa outra que à partida seria incompatível".

Para Arellano (2004, p.21), a emulação é uma técnica que tem como objetivo preservar o dado no seu formato original através de emuladores que "poderiam imitar o comportamento de uma plataforma de hardware obsoleta e emular o sistema operacional relevante". 
A vantagem da emulação sobre o refrescamento é que essa não necessita preservar o hardware original, pois o emulador é criado para ser utilizado na plataforma de hardware atual. A dificuldade do emulador consiste em desenvolver um software que reproduza corretamente o ambiente original.

Para o desenvolvimento do emulador é necessário conhecer detalhadamente o ambiente original para que não ocorra imprecisão na especificação do software. Também existe a necessidade de mão de obra especializada e qualificada que conheça detalhadamente a plataforma original. Esses fatores apontam para alto custo do desenvolvimento de um ambiente de emulação. Como a emulação está inserida na preservação digital, ela também sofrerá no futuro com o problema da obsolescência e, portanto, também necessitará de uma conversão para uma nova plataforma ou desenvolvimento de um novo emulador capaz de emular o primeiro.

A forma de prover informações necessárias para conhecer o ambiente e o formato do objeto digital é incluir na descrição do objeto digital anotações em ambiente digital atual, explicando como interpretar os bits referentes ao objeto digital (Rothenberg, 1999, p.16).

Essas anotações devem estar armazenadas digitalmente e associadas ao objeto digital, com um formato de codificação mais legível e atual para que possa ser entendido. As anotações descrevem tanto o ambiente de hardware necessário para emular o objeto digital quanto as características do software, e devem incluir dados sobre: hardware, sistema operacional, software, drives de acesso, mídias etc.

\section{Conservação do conteúdo intelectual do objeto digital}

A conservação do conteúdo intelectual do objeto digital é conhecida como migração e consiste na técnica de transferir periodicamente um objeto digital de uma tecnologia de hardware e/ou software para outra mais atual, preservando prioritariamente o conteúdo do objeto digital, podendo esse sofrer alterações na sua estrutura. 
Arellano (2004, p.20) define a migração como "a transferência periódica de materiais digitais de uma configuração de software/ hardware para outra, ou de uma geração de tecnologia computacional para a geração seguinte".

A migração elimina a necessidade de conservar o hardware e/ou o software, pois o documento original é modificado para ser utilizado em uma nova plataforma diferente daquela em que foi criado.

Com os constantes avanços das tecnologias, os formatos dos objetos digitais sofrem mudanças constantes, bem como podem ser substituídos por novos formatos. Apesar dos responsáveis por essas novas tecnologias buscarem processos que permitam a migração para os novos formatos, nem sempre isso é possível sem a perda de alguma característica do objeto digital original, em razão da incompatibilidade dos formatos ou até por falta de uma maior eficiência dos softwares de conversão.

Pesquisas demonstram que a migraçãoé uma das estratégias mais eficientes e mais utilizadas na preservação de documentos digitais.

Podemos encontrar diversas formas de migração, e entre elas podemos destacar:

\section{Migração para suportes analógicos}

Consiste em converter um objeto digital para um suporte não digital, ou seja, para um suporte analógico com o objetivo de aumentar sua longevidade. Como exemplos de suporte analógico, podemos citar o papel, o microfilme, entre outros.

Esse tipo de estratégia, entretanto, não permite o acesso on-line ou via web ao documento preservado, restringindo dessa forma o acesso dos usuários ao objeto, e também torna necessário um sistema de busca, com metadados, para a localização desse documento.

A partir do momento em que estamos envolvidos em um novo contexto, onde a informação digital cresce de maneira exponencial, os avanços nas TIC são constantes e mais rápidos, a cultura das pessoas, especialmente dos mais jovens, está fortemente inserida na era digital e esse contexto tecnológico não tende a mudar; essa estraté- 
gia não é adequada para a necessidade que as pessoas têm atualmente de recuperar e acessar a informação de maneira rápida e eficiente.

\section{Atualização de versões}

Consiste em converter um objeto digital de uma versão de software anterior para a mais atual. Isso ocorre com frequência, pois no contexto atual é bastante comum o lançamento de softwares com versões mais atualizadas, que buscam proporcionar aos usuários novas funcionalidades. Mas, normalmente, com essas novas funcionalidades vêm alterações nos formatos dos arquivos, o que exige a atualização do documento digital da versão anterior para a nova. Isso é uma estratégia comumente utilizada por instituições e pessoas, intuitivamente, pois essas necessitam dos documentos produzidos no software atual.

\section{Conversão para formatos concorrentes}

Consiste em converter o objeto digital de um formato digital para outro formato concorrente. $\mathrm{O}$ formato de um objeto digital depende do software utilizado e da solução utilizada por seu desenvolvedor. Podem acontecer duas situações: o desenvolvedor pode, ao realizar a atualização do software, mudar completamente o formato, ou o fornecedor, por algum motivo, pode descontinuar o software. Em ambos os casos, o documento digital original pode não encontrar no futuro uma solução que permita acessar seu conteúdo. Uma solução para esse tipo de problema é a conversão do formato original em formatos concorrentes que permitam dar mais segurança à recuperação da informação digital.

\section{Normalização}

Ferreira (2006, p.38) aponta que a normalização tem como objetivo "simplificar o processo de preservação através da redução do número de formatos distintos que se encontram no repositório de 
objetos digitais". Com um número adequado, simplificado e padronizado de formatos, o processo de migração torna-se mais simples, pois permite aplicação das estratégias de preservação uniformemente a todos os objetos digitais, diminuindo as rotinas de conversão e também os custos da preservação. Nessa situação, o responsável pela geração do objeto digital é também responsável pela geração desse nos formatos permitidos no repositório.

Nesse caso, é importante a escolha correta dos formatos aceitos para os objetos digitais com o objetivo de evitar problemas de obsolescência e de direitos autorais. Nesse sentido, a utilização de formatos abertos e independentes da plataforma permite o maior conhecimento do formato e também que diferentes configurações de hardware e software sejam capazes de interpretar esses formatos.

Podemos, entretanto, também observar que a utilização de padrões, sejam eles abertos ou não, não garante necessariamente a preservação do objeto digital, pois mesmo esses padrões são frequentemente substituídos por padrões mais atuais diante do ritmo acelerado que envolve os avanços nas TIC.

Os documentos digitais estão envolvidos em um ambiente de constantes e rápidas mudanças de paradigma que não necessariamente garantem a compatibilidade de um objeto digital nesse novo ambiente. Podemos citar como exemplo a evolução do modelo de banco de dados relacional para o modelo de banco de dados orientado a objetos, ou seja, não é possível migrar automaticamente de um padrão para outro, pois ambos são bastante diferentes em suas estruturas (Rothenberg, 1999, p.12 e 13).

\section{Migração a pedido}

Consiste em aplicar processos de conversão sempre no objeto digital original. Ao final de algumas migrações, realizadas ao longo do ciclo de vida do objeto digital, pode ocorrer uma alteração no formato original do objeto.

Como a eficiência de um processo de migração depende, especialmente, da qualidade dos conversores e da capacidade que o for- 
mato de destino possui para acomodar o conjunto de propriedades do formato de partida, os objetos resultantes da migração podem sofrer alguma modificação em relação ao objeto digital original.

esta abordagem possui como principal vantagem o fato de, uma vez construído o módulo de descodificação do conversor, apenas ser necessário desenvolver os codificadores específicos para cada formato de saída. Não obstante, será necessário suportar ao longo do tempo um conjunto alargado de conversores de modo a garantir a capacidade de transformar os objetos armazenados nos seus formatos originais para formatos que sirvam adequadamente às necessidades dos seus consumidores. (Ferreira, 2006, p.40)

\section{Migração distribuída}

Consiste em aplicar remotamente a um objeto digital um conjunto de conversores, acessíveis na internet, reduzindo assim os custos de preservação.

Para Ferreira (2006, p.42), esse tipo de migração apresenta algumas vantagens ante as estratégias de migração mais convencionais, como: esconder as especificidades de cada conversor e da plataforma que o suporta; disponibilidade de serviços redundantes, que permitem que o serviço resista ao desaparecimento gradual de parte dos conversores; compatível com uma série de variantes de migração, como normalização e migração a pedido; redução dos custos de preservação.

A desvantagem dessa estratégia é o fato de utilizar muito processamento distribuído na rede e muito acesso à internet, exigindo com isso grande capacidade de banda.

\section{Encapsulamento}

Consiste em manter o objeto digital original inalterado até que o acesso a ele venha a tornar-se necessário. Nesse momento que o objeto digital original deverá ser tratado. 
Para o tratamento, nesse caso, é necessário que, juntamente com objeto digital original, sejam preservadas informações relativas a esse objeto que permitam, no futuro, o desenvolvimento de emuladores, conversores ou outros instrumentos que favoreçam o acesso à informação digital contida no objeto.

\section{Pedra de Rosetta digital}

Como no caso da Pedra de Rosetta, descoberta no delta do Nilo em 1799, essa estratégia propõe preservar não as regras que permitem decodificar o objeto, mas amostras representativas desse objeto que permitam sua recuperação.

Existem também estudos para criação de diretórios centralizados de informação técnica sobre os formatos digitais com o objetivo de registrar informações sobre os formatos, como identificação dos produtores do formato, data da sua criação, quais as aplicações que o suportam, especificações técnicas, grau de obsolescência, entre outros.

Essas informações serão importantes como apoio às atividades de preservação digital, além de possibilitar o desenvolvimento de ferramentas para identificação do formato de um objeto digital.

Podemos observar que, para muitas estratégias de preservação, o sucesso dessa depende da qualidade dos conversores e da sua capacidade de manter o conteúdo e o formato original do objeto digital a ser preservado.

\section{Considerações finais}

Das estratégias de preservação apresentadas, podemos observar que a migração é a estratégia que mais evolui na preservação da informação digital, por tratar da questão do conteúdo do objeto digital a ser preservado no longo prazo.

A emulação torna-se uma estratégia muito cara, pois necessita da criação de um ambiente de software e hardware exatamente igual ao original. 
O refrescamento é uma estratégia que deve ser aplicada especialmente em razão da obsolescência dos suportes e dos hardwares necessários para sua escrita e leitura.

É necessário que as instituições adotem estratégias de preservação digital bem definidas em suas políticas para cada tipo de objeto digital, avaliando-as periodicamente para determinar qual a melhor estratégia a ser implementada de acordo com as tecnologias existentes naquele momento.

Observamos que podemos utilizar ao longo da vida do objeto digital estratégias de preservação diferentes, dependendo do contexto tecnológico da época em que o objeto digital deve ser tratado.

É consenso entre a maioria dos profissionais a necessidade do desenvolvimento de elementos de descrição que possam dar conta de todo o histórico das estratégias aplicadas a esse objeto digital, para que esse possa ser entendido no futuro pelos novos ambientes tecnológicos. Nesse sentido, a criação de metadados específicos de preservação é apontada como solução para essa descrição.

\section{Referências}

ARELLANO, M. A. Preservação de documentos digitais. Ciência da Informação, Brasília, v.33, n.2, p.15-27, 2004. Disponível em: $<$ http://www.scielo.br/pdf/ci/v33n2/a02v33n2.pdf>. Acesso em: 4 jan. 2007.

BARRETO, A. A. A oferta e a demanda da informação: condições técnicas, econômicas e políticas. Ciência da Informação, Brasília, v.28, n.2, p.168-73, 1999.

BOERES, S. A. A.; ARELlANO, M. A. M. Políticas e estratégias de preservação digitais de documentos. In: CINFORM: ENCONTRO DE CIÊNCIA DA INFORMAÇÃO, 6, 2005, Salvador. Anais... Salvador: UFBA, 2005. Disponível em: <http://www.cinform.ufba.br/vi_anais/docs / SoniaMiguelPreservacaoDigital.pdf $>$. Acesso em: 4 jan. 2007. CONARQ. Carta para a Preservação do Patrimônio Arquivístico Digital. Rio de Janeiro: Conarq, 2004. Disponível em: < http:// 
www.conarq.arquivonacional.gov.br/Media/publicacoes/ cartapreservpatrimarqdigitalconarq2004.pdf $>$. Acesso em: 17 jan. 2007.

DAHLBERG, I. Current trends in knowledge organization. In: ORGANIZACIÓN DEL CONOCIMIENTO EN SISTEMAS DE INFORMACIÓN (ISKO), 1, Madrid, 1995. Actas... Madrid, 1995.v.1; p.7-25

DUBLIN Core Metadata Initiative. Disponível em: <http:// dublincore.org >. Acesso em: 24 fev. 2009.

FERREIRA, M. Introdução à preservação digital: conceitos, estratégias e actuais consensos. Guimarães (Portugal): Escola de Engenharia da Universidade do Minho, 2006. Disponível em: <https:// repositorium.sdum.uminho.pt/bitstream/1822/5820/1 / livro.pdf>. Acesso em: 17 jan. 2007.

GANDELMAN, H. De Gutenberg à Internet: direitos autorais na área digital. 4.ed. Rio de Janeiro: Record, 2001.333p.

GILLILAND-SWETLAND, A. J. La definición de los metadatos. In: BACA, M. (Ed.). Introducción a los metadatos vías a la informacion digital. Los Angeles: J. Paul Getty Trust, 1998. p.1-9

GRÁCIO, J. C. A. Metadados para a descrição de recursos da Internet: o padrão Dublin Core, aplicações e a questão da interoperabilidade. Marília, 2002. 104f. Dissertação (Mestrado) - Programa de PósGraduação em Ciência da Informação, Universidade Estadual Paulista "Julio de Mesquita Filho".

MARTINS FILHO, P. Direitos autorais na Internet. Ciência da Informação, Brasília, v.27, n.2, p.183-8, 1998.

METS Metadata Encoding \& Transmission Standard: Official Web Site. Disponível em: <http://www.loc.gov/standards/mets/>. Acesso em: 27 jan. 2009.

National Library of Australia. Recent developments in digital archiving and preservation. 2006. Disponível em: <http://www.nla.gov.au/ nla/staffpaper/2006/documents/ pgatenby_CDNL.pdf>. Acesso em: 25 mar. 2009.

ROTHENBERG, J. Ensuring the longevity of digital information. 1999. Disponível em: <http://www.clir.org/pubs/archives/ ensuring.pdf $>$. Acesso em: 13 out. 2009.

SARAMAGO, M. de L. Metadados para preservação digital e aplicação do modelo OAIS. 2003. Disponível em: <http:// 
www.unicamp.br/siarq/doc_eletronico/metadados.pdf $>$. Acesso em: 22 abr. 2009.

STORY, A. et al. (Ed.) The Copy/South Dossier: issues in the economics, politics and ideology in the global South. Canterbury: The CopySouth Research Group, 2006. 210p. Disponível em: <http:// www.copysouth.org/en/documents/csdossier.pdf>. Acesso em: 15 jun. 2009.

THOMAZ, K. P.; SOARES, A. J. A preservação digital e o modelo de referência Open Archival Information System (OAIS). DataGramaZero, Rio de Janeiro, v.5, n.1, 2004. Disponível em: $<$ http://datagramazero.org.br/fev04/index.htm>. Acesso em: 4 ago. 2008 . 



\section{4 \\ MEDIAÇÃo ORAL LITERÁRIA: ALGUMAS PALAVRAS}

Sueli Bortolin

Oswaldo Francisco de Almeida Júnior

\section{Introdução}

Ir direto ao assunto seria a melhor opção, mas por que não fazer uma abertura falando da palavra, um aspecto fundamental no ato da mediação? Devemos pensar na palavra em suas múltiplas roupagens: escrita, falada, filmada, desenhada, cantada, declamada etc.

Mas o que é palavra? Poderíamos responder a essa pergunta utilizando os mais diversos textos, entre eles: etimológicos, semânticos, jornalísticos, científicos, jurídicos e outros; porém, optamos por um texto literário. Mais, especificamente, pela fala de um personagem que tira vantagens de inúmeras situações utilizando com maestria as palavras, e de tanto usá-las para fazer falcatruas foi "detido, cercado por palavras desagradáveis: falsa identidade, peculato, apropriação indébita, estelionato, vigarice" (Carrasco, 1994, p.73).

Esse personagem chama-se Júlio Malatesta e habita o livretonovela $O$ caçador de palavras, de Walcyr Carrasco. Júlio, apesar de rodeado de palavras tão negativas, confessa: "Fiquei fascinado pelas palavras, e pressenti que nesta paixão estava cravado meu destino. Mesmo agora, na cadeia, não me arrependo. Não vejo o tempo que passarei na prisão como um ponto final, mas como um contratempo [que] me deu sede de viver (ibidem, p.13). 
As palavras, não há dúvida, exercem forte poder nos membros do reino hominal e animal. Dizem, sem comprovação científica, que também as plantas são influenciadas pelas palavras pronunciadas em sua direção.

Não é sem motivo que agências de publicidade, instituições, comunicadores, políticos etc. frequentemente criam refrões, slogans, jingles, frases impactantes para reforçar imagens, marcas e produtos.

A própria literatura, em especial os contos tradicionais, é fértil de palavras mágicas: Era uma vez...; Abre-te, sésamo!; Abracadabra!

Essas palavras estão tão impregnadas em nossas mentes que já nem sabemos suas origens e o que significam.

A expressão Abre-te, sésamo, usada nas histórias de Ali Babá e os 40 ladrões, por exemplo, vem do latim sesamum, que é a planta do gergelim.

Segundo Brown (2009, p.392):

até hoje, as crianças gritam "abracadabra" na esperança de criar algo a partir do nada. É claro que todos nós esquecemos que essa palavra não tem nada a ver com brincadeira. Suas raízes estão no antigo misticismo aramaico: Avra Kedabra significa "Eu crio ao falar".

Se "eu crio ao falar", é sinal de que as palavras têm força e é com elas que acreditamos ser possível realizar mediações de leitura oral em todos os gêneros de biblioteca.

Este capítulo é parte de uma pesquisa em andamento que é intitulada Mediação oral literária: a voz do bibliotecário lendo ou narrando. Seu objetivo é contribuir na constituição de um corpus científico para a teoria Mediação Oral Literária (MOL) de maneira a subsidiar teórica e conceitualmente o bibliotecário ao trabalhar também com a informação não registrada.

Quanto aos procedimentos metodológicos, optamos pelo método bibliográfico, tendo como base teórica pesquisadores da área de ciência da informação, mas também da comunicação social, das letras, da educação e da história. 
Por ser o nosso país fortemente marcado pela oralidade, deveríamos iniciar a mediação literária utilizando textos orais. Assim, esperamos com essa investigação levar o bibliotecário a perceber a sua contribuição no projeto de ampliação do índice de leitura no Brasil, pois ao bibliotecário também cabe a responsabilidade de atuar como leitor-narrador, e para isso conta com um rico repertório cultural e literário.

\section{Marco teórico}

Marco teórico é o momento em que o pesquisador demarca quais são suas companhias na pesquisa e qual a trilha traçada para comunicar as ideias que estão sendo desenvolvidas na sua investigação.

Neste trabalho, além de textos técnicos e científicos, utilizamos textos ficcionais e a letra de uma música. Os subtemas abordados foram: leitura, apropriação da informação, oralidade, mediação literária e mediação oral literária.

\section{A leitura e a apropriação da informação: o que precede o quê?}

O senso comum afirma que apropriar é "tomar para si”, "apossar", "apoderar", "tornar próprio" etc. Aqui nos interessa abordar a apropriação no âmbito da ciência da informação. Isso porque acreditamos que os profissionais dessa área, sendo eles bibliotecários, arquivistas ou museólogos, necessitam colaborar com o cidadão, em qualquer faixa etária na busca da informação por meio da leitura.

Para Almeida Jr. (2004, p.75), "A apropriação da informação se dá no processo de mediação. A concretização efetiva da informação só pode ser determinada pelo usuário”.

O ato de apropriação não deve ser percebido como uma ação passiva em que o indivíduo acumula as mais diversas informações, mas não as compreende e nem as utiliza no seu cotidiano. Pelo contrário, 
"a apropriação da informação, que fique claro, pressupõe uma alteração, uma transformação, uma modificação do conhecimento, sendo assim uma ação de produção e não meramente de consumo" (Almeida Jr., 2007, p.36).

Essa ideia nos remete à educação e à concepção bancária de Paulo Freire (1987, p.33) quando defende não ser o educando um depósito de comunicados. Assim também não são o leitor e o pesquisador de uma biblioteca.

Partindo dessas orientações e das nossas experiências como bibliotecários e docentes do curso de Biblioteconomia, acreditamos que a resposta para o título-pergunta dessa subseção deva ser: a leitura abundante de textos tende a levar o indivíduo a se apropriar da informação com maior segurança, estando ela em diferentes linguagens e suportes.

Para Almeida Jr. (2007, p.34) "a leitura está no cerne da apropriação da informação. Esta não existe a priori, não existe antecipadamente; por ser intangível, não concreta, apenas se concretiza no processo de mediação [...] enfim, a leitura é que possibilitará sua apropriação".

Nesse sentido, consideramos fundamental o desenvolvimento de projetos que orientem o indivíduo à busca da informação, mas antes disso são necessários projetos contínuos de leitura, com o investimento de verbas, capacitação de grupos de trabalho, publicação de documentos, montagem de estruturas administrativas, enfim, uma política de Estado e não de governo para a leitura, evitando que na mudança de gestão esses projetos sejam substituídos e/ou eliminados.

Não há dúvida de que o bibliotecário é um dos principais profissionais a coordenar iniciativas nesse sentido, mas lamentavelmente a maioria ainda restringe a sua atuação em atividades técnicas e rotineiras, mesmo com o advento das tecnologias.

É também necessário o engajamento de líderes comunitários, religiosos, políticos, de forma a levar o cidadão a se apropriar de variados textos, para que em consequência disso possa também se apropriar da informação. 
Para a maioria da população, apropriar-se da informação não é uma tarefa tão simples quanto parece. Temos carências no acesso aos bens culturais, insuficiência de unidades de informação nos bairros periféricos, despreparo dos profissionais para orientar o cidadão na busca de informação.

As carências no Brasil são tão grandes que nem é possível quantificar. Para ilustrar, incluímos aqui o trecho do romance Vidas secas, de Graciliano Ramos, quando o personagem Fabiano, angustiado por ter sido ludibriado, maltratado, humilhado e preso injustamente por um agente policial, busca palavras para se defender, mas seu vocabulário é escasso. E ele, solitário em sua cela, pergunta indignado:

Afinal para que serviam os soldados amarelos? Deu um pontapé na parede, gritou enfurecido. Para que serviam os soldados amarelos? Os outros presos remexeram-se, o carcereiro chegou à grade, e Fabiano acalmou-se:

- Bem, bem. Não há nada não.

Havia muitas coisas. Ele não podia explicá-las, mas havia. Fossem perguntar a seu Tomás da bolandeira, que lia livros e sabia onde tinha as ventas. Seu Tomás da bolandeira contaria aquela história. Ele, Fabiano, um bruto, não contava nada. (Ramos, 1980, p.34)

Essa manifestação autêntica de Fabiano ocorre diariamente e com uma grande parcela da população brasileira, que por falta de leitura e informação fica alijada de decisões cotidianas importantes.

Tivemos com esse recorte do romance Vidas secas a intenção de demonstrar que a leitura, nesse caso a literária, nos leva a refletir sobre as condições sociais de uma comunidade e nos apropriar, mesmo que minimamente, de informações a respeito do nosso país.

\section{O uso da oralidade no cotidiano}

A vasta literatura que aborda a temática da oralidade tem como sustentação basilar pesquisadores comoWalter Ong, Paul Zumthor, David R. Oslon, Nancy Torrance, Eric Havelock, Peter Burke etc. 
Entre esses, o autor com o qual nos identificamos com maior intensidade é Paul Zumthor. Isso porque ele propaga ideias relevantes para a abordagem da nossa tese, ideias que estamos resumindo em quatro palavras chaves: voz, corpo, espaço e presença.

Zumthor, em sua extensa obra, analisa a atuação dos praticantes da voz, entre eles: cancioneiro, recitador, trovador, menestrel, carpideira, cançonetista, gondoleiro, satirista, cantor, narrador de histórias, cordelista, leitor público etc.

Esses sujeitos no passado realizavam suas performances em espaços abertos, como praça pública. Atualmente, a maioria, por diferentes questões, restringe sua atuação em lugares reservados e muitas vezes elitizados.

Outro aspecto interessante dos livros desse autor é a diferença que ele estabelece entre oralidade e vocalidade. "Oralidade é um termo histórico [que] designa um fato que diz respeito às modalidades de transmissão: significa simplesmente que uma mensagem é transmitida por intermédio da voz e do ouvido..." (Zumthor, 2005, p.1167) e vocalidade refere-se a "uma noção antropológica, não histórica, relativa aos valores que estão ligados à voz como voz e, portanto, encontram-se integrados ao texto que ela transmite" (ibidem, p.117).

Com essa diferenciação, Zumthor nos leva a inferir que um texto vocalizado é enriquecido pelos demais componentes de uma performance, istoé, gestos, vestimentas, ruídos, pausas, risos, suspiros, enfim, a ambiência ${ }^{1}$ construída pelo leitor-narrador somada à presença do leitor-ouvinte.

Lembramos que a voz está ligada ao gesto, e que é uma manifestação corporal espontânea. Se não conseguimos emitir palavras, por diferentes razões biológicas, emitimos grunhidos; se não conseguimos emitir grunhidos, utilizamos as mãos. Além disso, acreditamos que há uma voz permanentemente dentro de nós. Há um texto dentro do nosso corpo e o corpo reage a ele.

1 Nossa concepção de ambiência tem influência da arquitetura, quando Belintane (2002, p.185) afirma: "para os arquitetos uma ambiência é um meio físico, mas, ao mesmo tempo, estético e psicológico planejado para interações humanas”. 
Para Gaiarsa (1986, p.14): "o que dá sustentação, a força e sentido aos pronunciamentos verbais é precisamente a cara, o tom de voz, o gesto e a posição. Tudo isso numa cena, isto é, numa situação". Portanto, o corpo é fundamental em nossas manifestações orais.

A leitura de trabalhos científicos de diferentes áreas tem demonstrado que há uma classificação simples e objetiva para a oralidade, isto é, oralidade ancestral e nova oralidade. Sendo a última grafada em itálico, pois na avaliação dos pesquisadores não é a expressão mais apropriada; visto não se tratar de algo novo, mas da transposição da voz viva para diversas tecnologias, produzindo a voz mediatizada.

Zumthor (2005, p.127), abordando a nova oralidade, destaca que "o disco, na medida em que existe materialmente, subsiste como o faz o livro. O que favorece hoje o retorno à voz é justamente a existência desses meios de que dispomos de beneficiar a voz...".

A oralidade ancestral é a oralidade pura, não modificada, que está viva dentro de nós. Ela interioriza "a memória, do mesmo modo que a espacializa: a voz se estende num espaço, cujas dimensões se medem pelo alcance acústico..." (Zumthor, 1997, p.42). Podendo ser manifestada por meio do grito, do choro, da gargalhada, da canção e das mais diferentes comunicações textuais.

A fim de entender o processo de oralização dos povos, apoderamo-nos de Havelock (1997, p.27), quando lembra que:

nossa herança oral faz parte de nós tanto quanto a habilidade de andar ereto ou usar as mãos, seria possível essa herança se permitir ser rapidamente suplantada pelo que chamamos de cultura escrita? [...] Deixando de lado os incontáveis milênios em que as sociedades humanas foram exclusivamente orais, pode-se concluir que, dos egípcios e sumérios aos fenícios e hebreus (para não mencionar os indianos e os chineses), a escrita nas sociedades onde era praticada restringiu-se às elites clericais ou comerciais, que se dava o trabalho de aprendê-la. As atividades ligadas à justiça, governo e vida cotidiana ainda eram comandadas pela comunicação oral, como hoje ainda acontece em grande parte no mundo islâmico e até mesmo na China. 
Assim, usando a oralidade ancestral, a nova oralidade ou as duas ao mesmo tempo, os profissionais de diferentes áreas têm consciência de que a comunicação oral ainda é imprescindível nas relações humanas. Isso se explica porque, apesar das barreiras que temos de nos fazer entender, o humano continua sentindo a necessidade de ouvir e pronunciar.

Essa atmosfera de oralidade nos lembra uma obra inquietante e que deve fazer parte da biblioteca daqueles que se interessam pela leitura, trata-se de Fahrenheit 451 (Bradbury, 2003). Essa obra narra o modo de vida de uma sociedade em que os livros representavam perigo, portanto eram proibidos. Para cercear a leitura os bombeiros, que anteriormente apagavam incêndios, passam a atear fogo nos livros, impedindo a transmissão de conhecimentos. Na contramão surgem pessoas denominadas homens-livros, que passam a memorizar as obras para não serem esquecidas.

Para destacar o registro não físico de documentos e as possibilidades orais desse grupo de pessoas, trazemos os argumentos de um deles:

Tudo que queremos fazer é manter o conhecimento que, pensamos, precisamos manter intacto e seguro. Ainda não estamos prontos para incitar ou enfurecer ninguém. Pois, se formos destruídos, o conhecimento estará morto, talvez para sempre. Somos cidadãos-modelo, à nossa maneira: caminhamos pelos velhos trilhos, passamos a noite nas colinas e as pessoas das cidades nos deixam em paz. (ibidem, p.187)

Apesar da paz que reinava nos lugares onde os homens-livros circulavam, eles se sentiam num constante clima de guerra, eram seguidos, revistados, "vagabundos por fora, bibliotecas por dentro" (ibidem, p.188).

Evidentemente que não será preciso nos transformar em homenslivros dessa maneira. Especialmente porque talvez não tenhamos mais essa capacidade de memorização. Porém, existem no nosso cotidiano outras mediações orais possíveis de ser realizadas, entre elas: colagens poéticas, rodas de leitura, clubes de leitura, montagens de 
jograis, leituras públicas de textos (em hospitais, praças, ônibus, restaurantes, rádio e televisão), saraus literários, bate-papo com escritores, oficinas de produção e leitura de textos, festivais de filmes, entrevistas com pioneiros, realização de encontros com repentistas e cordelistas, cantorias, sessões de piadas, causos, adivinhações, parlendas, travalínguas etc.

Dessas formas ou de outras não citadas e nem experimentadas, é essencial que os textos literários sejam expostos. É imprescindível que novos espaços sejam assumidos como possíveis e que a presença do bibliotecário não seja apenas complementar, mas marcante e decisiva.

\section{Mediação literária}

Antes de abordar a mediação literária, gostaríamos de refletir a respeito do que é literatura e a importância dela no cotidiano do cidadão.

No âmbito científico e acadêmico, literatura é o conjunto de comunicações de uma determinada área do conhecimento; porém, de forma específica, literatura é o conjunto de composições literárias, distribuída nos gêneros: narrativo, lírico e dramático. Sendo o narrativo composto por romances, fábulas, novelas, contos etc.; o lírico, por textos de construção poética; e o dramático, pelos voltados à dramaturgia.

Nessa classificação rápida é possível vislumbrar a existência de uma enormidade de textos e de palavras que circundam o leitor e também uma grande possibilidade de leitura ao seu dispor. Pensando nisso nos perguntamos: "para que serve a literatura?".

Essa resposta nos é dada por Carvalho (2001, p.58), quando disserta:

Entre os teóricos parece não haver dúvidas de que a literatura é uma arte que possui uma constituição estética própria, em que há uma intenção de trabalhar a linguagem verbal com vistas a fazer dela um modo 
singular de revelar a realidade ou de criar um mundo imaginário a partir dessa realidade.

Revelando a realidade ou criando um mundo imaginário, a literatura tem um papel essencial na sociedade, o de impulsionar o cidadão a uma atitude empática, pois, ao se colocar no lugar do outro, estabelece-se uma relação de proximidade e quase sempre de solidariedade e compreensão.

Lendo e se identificando com um personagem, em geral, o leitor respeita suas fraquezas, suas decisões muitas vezes equivocadas, mas também esse personagem serve de modelo a ser seguido.

Novamente nos apoiamos em Carvalho (2007, p.16), quando alerta:

Por ser a literatura uma arte que não visa à verdade dos fatos nem se coloca como uma forma de especulação sobre a vida, os homens e a realidade, ela acaba por se diferenciar de outros tipos de textos e assim mantém com o seu receptor uma comunicação estética que envolve, além da inteligência, a emoção e o afeto. Isso significa dizer que a literatura institui um tipo de comunicação que ultrapassa a razão, e requer uma relação com o leitor que prevê a sua interação afetiva.

Isso talvez também signifique dizer que a literatura, com a força das palavras que a compõe, tende a provocar a diminuição do conflito tão desgastado da objetividade e subjetividade, levando o indivíduo a perceber o outro e a perceber-se, isto é, exercitando a razão e a sensibilidade.

Para Barthes (1992, p.18-9), "o saber que [a literatura] mobiliza nunca é inteiro nem derradeiro; a literatura não diz que sabe alguma coisa, mas que sabe de alguma coisa; ou melhor: que ela sabe algo das coisas - que sabe muito sobre os homens".

Numa comunhão, a literatura sabe sobre os homens, e o homem lendo literatura tem a possibilidade de aprender muito sobre si, sua coletividade e a vida. Pensando assim, a leitura deve ser entendida de forma plural, não se limitando apenas ao texto escrito, pois dessa forma estaríamos excluindo os leitores não alfabetizados. 
Outro aspecto que deve ser observado é que a leitura pode ser realizada solitária ou coletivamente. Qual é a melhor forma? Não há uma ação melhor ou pior, são duas ações diferentes, e a diferença está em que a leitura individual é compartilhada, quase sempre a posteriori, e a coletiva, no momento em que é executada, portanto mais dinâmica e com maiores possibilidades de troca.

\section{Mediação Oral Literária (MOL)}

Para falar da Mediação Oral Literária retomamos as reflexões do personagem de Walcyr Carrasco (1994, p.74), quando ele diz que as palavras são: "como diamantes solitários e, no entanto, elas criam relações, promovem mundos. Se as palavras passam de pessoa para pessoa, é porque os seres se conhecem, se comunicam, fazem trocas".

Assim também são as narrativas orais, elas passam de pessoa para pessoa, melhor dizendo, de boca em boca, e tecem o acervo cultural dos diferentes povos e nações.

Vale lembrar que nas sociedades de predominância rural, existiam rituais e cantorias de acordo com a semente a ser plantada. Havia a proibição de manifestações orais em determinados períodos por acreditarem que podiam proliferar as plantas daninhas, interferindo no rendimento econômico familiar.

Abordando especificamente as narrativas orais, destacamos que elas podem ocorrer de duas maneiras: pela leitura em voz alta ou a narração livre realizada por um leitor-narrador. Leitor-narrador que na nossa concepção é todo indivíduo que medeia o encontro do leitor-ouvinte com diferentes textos (de origem escrita ou oral), utilizando o seu suporte vocal para ler ou narrar histórias.

Destacamos que há diferença de um modo de narrar e do outro, pois acreditamos que a leitura em voz alta é feita do texto na íntegra por um leitor-narrador e na narração livre há a presença de outros elementos que compõem a performance, entre eles: o corpo do narrador, a ambiência construída no momento da narrativa, o clima que integra o narrador e o espectador. 
Compartilhar as obras com outras pessoas é importante porque torna possível beneficiar-se da competência dos outros para construir o sentido e obter o prazer de entender mais e melhor os livros. Também porque permite experimentar a literatura em sua dimensão socializadora, fazendo com que a pessoa se sinta parte de uma comunidade de leitores com referências e cumplicidades mútuas. (Colomer, 2007, p.143)

Voltando ao livro Fahrenheit 451 (Bradbury, 2003), é possível afirmar que os esforços dos homens-livros valiam a pena e isso pode ser percebido na resposta de um deles quando perguntado se acreditava que um dia as pessoas iriam parar para ouvi-lo, e ele responde imediatamente:

- se não ouvirem, teremos simplesmente de esperar. Passaremos os livros adiante a nossos filhos, de boca em boca, e deixaremos que nossos filhos, por sua vez, sirvam a outras pessoas. É claro que muito se perderá dessa maneira. Mas não se pode obrigar as pessoas a escutarem. (ibidem, p.188)

Querer escutar, ver e ler é uma opção pessoal, mas apenas escutando, ouvindo e lendo as pessoas poderão se apropriar de conceitos e informações que podem alterar o seu cotidiano. Feliz ou infelizmente, depende do ponto de vista, na atualidade, isso tem sido exigido cada vez mais do cidadão.

Ao abordar resumidamente a concepção de Martin Heidegger para o termo Ereignis, o Núcleo de Estudos Filosóficos da Comunicação da Escola de Comunicação e Artes (ECA/USP) destaca:

o filósofo separa, no verbo ereignen (acontecer), o prefixo er da raiz eignen. Este, o verbo eignen, significa pertencer [grifo nosso] a alguém, prestar-se a, e é aparentado com o termo "eigen", próprio, particular. Num segundo momento, portanto, além de acontecer, o termo quer dizer apoderar-se [grifo nosso], como na expressão zu eigen machen: apropriar-se de alguma coisa. Em terceiro lugar, Heidegger diz que "eignen" vem de "äugnen", vinculada a Auge (olho), que sig- 
nifica descobrir com o olhar [grifo nosso], despertar com o olhar. (Núcleo..., 2010, p.77)

Identificamo-nos com os três significados apresentados por acreditar que os verbos pertencer, apoderar-se e descobrir com o olhar estão na essência da Mediação Oral Literária. O leitor-ouvinte, no momento da narrativa oral, primeiro experimenta o sentimento de pertença em relação ao grupo, depois ele se apropria dos textos e, para confirmar esse interesse, muitas vezes pede que um mesmo texto lhe seja lido ou narrado inúmeras vezes. Essa apropriação acontece por meio da audição, mas também pelo olhar, quando ele lê os textos presentes no corpo do leitor-narrador e no seu entorno.

Fazendo uma intersecção entre a apropriação da informação e a mediação oral literária, concordamos com Fleck (2009, p.33) quando afirma: "não se pode negar que, ao contar histórias, inúmeras informações se transmitem, tanto informações concretas (como um objeto mostrado à plateia) quanto aquelas que conduzem à imaginação e que são de natureza subjetiva”.

Acreditamos nisso e gostaríamos de ver um maior número de bibliotecários tomando a palavra para mediar a leitura por meio de textos literários.

\section{Resultados parciais}

Até a presente data é possível vislumbrar que o número de bibliotecários envolvidos com narrativas orais ainda é irrisório. A restrição dessas atividades apenas nas bibliotecas escolares e infantis é um equívoco, pois é viável a sua realização também em empresas públicas e privadas.

Percebemos por meio de conversas pessoais, contatos informais, troca de mensagens eletrônicas que há um conceito reducionista desse profissional quanto ao ato de ler em voz alta ou narrar textos literários.

Além disso, o mediador de leitura deve buscar se apropriar e aprofundar em áreas fora da ciência da informação. Citamos como 
exemplo a teoria de Hans Robert Jauss denominada estética da recepção, ${ }^{2}$ que traz subsídios ao fazer cotidiano do bibliotecário.

Avaliamos que, apesar de serem recursos que podem enriquecer a narrativa, não é imprescindível a utilização de objetos, vestuários, músicas e instrumentos musicais, a voz oriunda do corpo é o principal elemento dessa ação.

O leitor-narrador precisa, portanto, conhecer o acervo textual brasileiro e estrangeiro, possibilitando a diversificação e o domínio da narrativa de maneira a ampliar no leitor-ouvinte a visão de si e do mundo.

O mediador de leitura deve avaliar o local onde desenvolverá a mediação. Ele não precisa ser sofisticado, mas propiciar acomodação confortável ao leitor-ouvinte e ambiente com acústica e ventilação adequadas. No entanto, a preocupação principal deve ser a construção de uma ambiência para narrativa levando em conta que o imaginário e o prazer estético são fundamentais aos indivíduos em qualquer faixa etária. Com criatividade e flexibilidade no banco de uma praça pode-se criar um clima propício à narrativa.

\section{Considerações finais}

Após falar, entre outros assuntos, de manifestações orais e apropriação da informação, colocaremos isso em prática, pois vamos nos apropriar de uma das manifestações orais mais presentes em nossas vidas na atualidade: a música.

Escolhemos uma música que trata da palavra, pois palavra foi o fio condutor desse texto. O título dela é "Mama palavra" e foi composta por João Bosco e seu filho Francisco Bosco.

2 Sugerimos como leitura inicial o livro Estética da recepção e história da literatura, de Regina Zilberman (1989). 


\section{MAMA PALAVRA ${ }^{3}$}

Se disparada pelo amor

Palavra-bala

$\mathrm{Na}$ boca do ditador

Toda palavra cala

Ô, mama

Cala palavra

Ô, mama, ô, mama

Mama palavra

Quando não se quer ouvir

Palavra-mala

Quando não se faz sentir

Pobre palavra rala

Ô, mama

Rala palavra

Ô, mama, ô, mama

Mama palavra

Em volta da mesa do bar

Palavra-porre

Se o tédio me assaltar

Palavra me socorre

Ô, mama

Cada palavra

Ô, mama, ô, mama

Mama palavra

Se gritar pega ladrão

Palavra corre

Quando não se tem tesão

Toda palavra morre

3 "Mama palavra". Disponível em: <http://vagalume.uol.com.br/joao-bosco/ mama-palavra.html>. Acesso em: 12 mar. 2010. 
Ô, mama

Morre a palavra

Ô, mama, ô, mama

Mama palavra

Mãe de todos nós

Dos sem mãe

Dos sem voz

$\mathrm{Na}$ fala do policial

Palavra-malha

No Distrito Federal

Toda palavra encalha

Toda palavra encalha

Aquela que não funcionar

Palavra-falha

Aquela que não se juntar

Vira palavra-tralha

Tralha

Quando tudo fala igual

Palavra-palha

Pra tudo que é marginal

Palavra que batalha

Palavra que batalha

Aquela que não funcionar

Palavra-falha

Aquela que não se juntar

Vira palavra-tralha

Tralha.

Sem a intenção de realizar uma análise, pois isso é função de especialistas, esse poema-música provocou uma vontade de compartilhamento. Um impulso de falar qual é a nossa percepção do jogo de palavras agrupadas propositalmente pelos compositores. 
Devemos começar pela palavra "Mama" no título, que representa a "Mãe de todos nós/Dos sem mãe/Dos sem voz", mas também pode ser a parte do corpo feminino que produz o leite que nos alimenta. Assim, nutridos pelas palavras, temos e damos vida.

Os demais conjuntos de palavras distribuídos nas estrofes têm ora uma intencionalidade explícita, ora velada, cabendo ao leitor e ao mediador, num processo de integração, descobri-las.

Fazendo um exercício de interpretação, a seguir elencamos dentro dos parênteses algumas possibilidades de leitura: "se disparada pelo amor palavra-bala" (doce ou projétil); "na boca do ditador toda palavra cala" (mordaça ou eliminação); "quando não se quer ouvir palavra-mala" (fechada, pesada ou entediante); "quando não se faz sentir pobre palavra rala" (sem conteúdo, fraca); "quando não se tem tesão toda palavra morre" (desamor, indiferença, desinteresse, "morte em vida"); "no Distrito Federal toda palavra encalha" (morosidade, lamaçal, discurso prolixo); "aquela que não se juntar vira palavra-tralha” (inútil, desnecessária), "quando tudo fala igual palavra palha" (áspera, sem sabor).

Além disso, percebemos que há uma repetição proposital de palavras. Há também as rimas (amor-ditador, bala-cala, ouvir-sentir, mala-rala etc.), que, quando oralizadas na voz do artista, ecoam como um apelo para que a palavra não vire tralha.

Enfim, nossas últimas palavras são para destacar que a proposta da mediação oral literária tem como base a ideia do retorno dos serões da Dona Benta ou dos momentos de encantamento que aconteciam debaixo de grandes árvores, em volta de pequenas fogueiras ou dentro das casas, onde era possível escutar os splac! splac! do barulho dos gravetos sendo consumidos pelo fogo.

\section{Referências}

ALMEIDA JÚNIOR, O. F. de. Profissional bibliotecário: um pacto com o excludente. In: BAPTISTA, S. G.; MUELLER, S. P. M. 
(Org.) Profissional da informação: o espaço de trabalho. Brasília: Thesaurus, 2004. p.70-86.

Leitura, mediação e apropriação da informação. In: SANTOS, J. P. (Org.) A leitura como prática pedagógica na formação do profissional da informação. Rio de Janeiro: Fundação Biblioteca Nacional, 2007. p.33-45.

BARTHES, R. Aula. 6.ed. São Paulo: Cultrix, 1992.

BELINTANE, C. Por uma ambiência de formação contínua de professores. Cadernos de Pesquisa, São Paulo, n.117, p.177-93, nov. 2002. BRADBURY, R. Fahrenheit 451. São Paulo: Globo, 2003.

BROWN, D. O símbolo perdido. Rio de Janeiro: Sextante, 2009.

CARRASCO, W. O caçador de palavras. 4.ed. São Paulo: Ática, 1994. (Encarte do Minidicionário Luft).

CARVALHO, N. C. de. Leitura literária: o processo de comunicação literária e a formação do leitor crítico. In: AGUILERA, V. de A.; LÍMOLI, L. (Org.) Entrelinhas, entretelas: os desafios da leitura. Londrina: Eduel, 2001. p.53-63.

A leitura literária e a formação do leitor competente. Máthesis - Revista de Educação, Jandaia do Sul, v.8, n.1, p.9-32, jan./jun. 2007.

COLOMER, T. Andar entre livros: a leitura literária na escola. São Paulo: Global, 2007.

BOSCO, J.; BOSCO, F. Mama palavra. Disponível em: <http:// vagalume.uol.com.br/joao-bosco/mama-palavra.html>. Acesso em: 12 mar. 2010.

FLECK, F. de O. A profissionalização do contador de histórias contemporâneo. Florianópolis: UFSC, 2009. 89f. Dissertação (Mestrado)Programa de Pós-Graduação em Ciência da Informação - Universidade Federal de Santa Catarina.

FREIRE, P. Pedagogia do oprimido. 11.ed. São Paulo: Paz e Terra, 1987. GAIARSA, J. A. O que é corpo. São Paulo: Brasiliense, 1986.

HAVELOCK, E. A equação oralidade - cultura escrita: uma fórmula para mente moderna. In: OLSON, D. R.; TORRANCE, N. (Org.) Cultura, escrita e oralidade. 2.ed. São Paulo: Ática, 1997. (Coleção Múltiplas Escritas).

MANGUEL, A. No bosque do espelho. São Paulo: Cia. das Letras, 2000. NÚCLEO de Estudos Filosóficos da Comunicação [FiloCom]. O conceito de acontecimento em Heidegger. São Paulo: ECA/USP. Disponí- 
vel em: <http://www.eca.usp.br/nucleos/filocom/heidegger. doc >. Acesso em: 12 mar. 2010.

RAMOS, G. Vidas secas. Rio de Janeiro: Record, 1980.

ZILBERMAN, R. Estética da recepção e história da literatura. São Paulo: Ática, 1989.

ZUMTHOR, P. Introdução à poesia oral. São Paulo: Hucitec, 1997. . Escritura e nomadismo. Cotia: Ateliê Editorial, 2005. 



\title{
5 \\ CONTRIBUIÇÕES TEÓRICAS E METODOLÓGICAS DA SOCIOLOGIA DO CONHECIMENTO PARA ESTUDOS DE PRODUÇÃO DE CONHECIMENTO EM CONTEXTOS EMPRESARIAIS
}

Luana Maia Woida

\begin{abstract}
"A verdade é que a obra e sua ideia passam a existir durante o processo da criação. Todo "fator real", toda linha já desenhada, todo movimento de mão, não somente determinam aqueles que lhe seguirão, mas também criam novas possibilidades não sonhadas de antemão."
\end{abstract}

(Mannheim, 1962, p.45)

\section{Introdução}

O conhecimento é compreendido como objeto de estudo por diversas áreas, como ocorre há milênios com a filosofia e, mais recentemente, com a sociologia do conhecimento. A ciência da informação também demonstra interesse pelo conhecimento como objeto, uma vez que desenvolve estudos sobre a produção e uso de conhecimento em ambientes organizacionais. $O$ ponto de vista social encontra-se presente nessa área, por exemplo, em processos de mediação, constituindo-se fundamentais porque representam a relação entre os profissionais da informação e os usuários. Nesse sentido, a 
realidade, o ponto de vista e os processos socioculturais são aspectos importantes para compreender a produção de conhecimento.

De forma mais abrangente, fazer uso da sociologia do conhecimento pode ser estendido para estudos sobre os fundamentos das linhas teóricas e dos pressupostos aparentes defendidos pelos teóricos e pesquisadores da ciência da informação, além de contribuir para avaliar e compreender as ideias formadas e evidenciadas nos posicionamentos defendidos. O presente texto restringe a discussão às linhas de investigação como a inteligência competitiva, a gestão do conhecimento e a cultura informacional utilizadas na ciência da informação, justificando a necessidade de compreender melhor o funcionamento da produção de conhecimento a partir da perspectiva social, historicista e dinâmica na área.

O ambiente econômico e político é responsável por uma parcela do direcionamento da produção de conhecimentos em linhas teóricas e em conhecimentos sobre a vida cotidiana. Tal ambiente é um aspecto importante porque se constitui como ponto de referência para essa produção. No que diz respeito ao ambiente organizacional competitivo, a produção de conhecimento se mostra bastante afetada por ele. O impacto que a esfera econômica exerce sobre as empresas é um dos principais fatores que as incentivam a buscar melhorias em seus processos, incluindo a produção de conhecimento, como forma de preparar soluções adequadas às exigências dessa esfera. Esse comportamento proativo é declarado fundamental pela teoria defendida em argumentos que compõem parcialmente a linha de gestão, na ciência da informação; fato relevante e que demonstra teoricamente o pressuposto de que existe influência da esfera econômica sobre a produção de conhecimento no ambiente empresarial.

Além da esfera econômica como ponto de referência, e em relação ao qual os conhecimentos são gerados, existe também a influência do contexto histórico de cada empresa na adoção de práticas que visam à construção e uso de conhecimento. A história da administração ou da teoria geral da administração mostra a evolução de suas áreas e de como cada uma delas representou em suas escolas o que considerava sobre cada um dos componentes do ambiente organiza- 
cional, ora deixando mais sobressalente as tecnologias, ora ressaltando as pessoas, ora a informação e, mais atualmente, o conhecimento. Percebe-se que o conhecimento, como um bem intangível, galgou espaço e se perpetuou como objeto de interesse para a gestão. Nesse caso, houve uma mudança de percepção sobre os objetos nas linhas teóricas. Desse modo, a teoria geral da administração mostra também a transformação e a consolidação do conhecimento como objeto de investimento pelas empresas. Eessas, por sua vez, demonstram na prática e em suas histórias particulares a tendência verificada pelas escolas e áreas da teoria geral da administração. Além disso, as organizações erigem a própria história, considerada para a presente discussão como determinante e coadjuvante na construção do conhecimento organizacional.

Outro determinante sobre a produção do conhecimento são os aspectos socioculturais. As classes ou grupos estratificados no interior organizacional influenciam a produção de conhecimento. $\mathrm{Ou}$ seja, trata-se de identificar o que é considerado válido ou não para o grupo, dentro de cada classe da estrutura. A distribuição e diferenciação na produção e no uso do conhecimento é passível de ser verificada, uma vez que as divisões em grupos mais comuns seguem a disposição dos estratos: nível estratégico, nível tático e nível operacional. A estrutura organizacional e as divisões que ocorrem a partir dela são importantes determinantes para compreender a construção de conhecimento. Além disso, representam os tipos de conhecimento que podem ser associados à produção e uso que ocorre em cada grupo.

Em suma, a realidade para as empresas se constitui pela esfera de referência principal, bem como por outros determinantes, como é o caso da história particular de cada uma e da estrutura que as compõe. Porém, a visão estática da estrutura organizacional é admitida para facilitar a compreensão, mas não representa toda a complexidade envolvida no processo de construção de conhecimento, muito menos na dinâmica natural dos fluxos informais presentes nas organizações.

Desse modo, parece mais evidente que a sociologia do conhecimento também pode ser base para estudos que visam à produção $\mathrm{e}$ 
ao uso de conhecimentos organizacionais em ambientes competitivos, investigando em que medida uma visão de mundo influencia nessa dinâmica de construção e uso. Além disso, outros questionamentos secundários podem recair ao conhecimento produzido no ambiente organizacional, por exemplo, como ocorre a influência do posicionamento de grupos nos fluxos de comunicação e de conhecimento na estrutura organizacional.

Mannheim (1962, p.55) chama a atenção para a presença perspectivista no processo de compreensão das ideias, pois "Tanto $o$ que nos é acessível das intuições essenciais de épocas passadas quanto como elas se tornaram acessíveis para nós dependem de nossa própria posição”.

A perspectiva é decisiva para compreender as formas pelas quais um sujeito percebe o mundo e se mostra também presente no contexto empresarial, uma vez que é essa perspectiva ou visão de mundo que se encontra expressamente difundida na cultura organizacional da empresa, influenciando, sobretudo, a construção e o uso de conhecimento pelos sujeitos dela participantes. Nesse sentido, Mannheim (1972, p.290) aponta para o fato de que não se pode alcançar a compreensão plena do conhecimento ou saber quando se desconsidera que ele é produto do contexto social e histórico. Se se tomar tal questão como um pressuposto, parece inevitável a necessidade de se levar a cabo estudos culturais de ambientes organizacionais competitivos, pois é por meio desses estudos que se chega à compreensão dos mecanismos de produção e uso, bem como do significado real do conhecimento organizacional.

A sociologia volta-se ao ambiente organizacional de fábricas e empresas com estudos destinados aos grupos e a temas que representam, por exemplo, o confronto entre profissionais que atuam nesse ambiente.

A sociologia do conhecimento possui relação com a teoria da ideologia, porém se distingue dessa pelo fato de não se concentrar em desvendar conhecimentos e verdades disfarçados ou embutidos. O interesse se dá especialmente em compreender as mudan- 
ças de perspectiva que os objetos de conhecimento assumem em momentos variados.

De acordo com Berger \& Luckmann (2004), a sociologia do conhecimento deve ser percebida de uma forma mais próxima ao conhecimento produzido no cotidiano, concentrando-se em compreender quais os mecanismos ou processos sociais fundamentais para estabelecer as leituras de mundo (perspectivas) adotadas por um grupo e que influem na construção do conhecimento e da própria realidade:

uma disciplina que se chama a si mesma por esse nome terá de ocuparse dos modos gerais pelos quais as "realidades" são admitidas como "conhecidas" nas sociedades humanas. Em outras palavras, uma "sociologia do conhecimento" terá de tratar não somente da multiplicidade empírica do "conhecimento" nas sociedades humanas, mas também dos processos pelos quais qualquer corpo de "conhecimento" chega a ser socialmente estabelecido como "realidade". (ibidem, p.13)

A posição relativista é bastante frequente entre os teóricos da sociologia do conhecimento, porque se propõe a análises e investigações de conhecimentos situados e relativos a uma esfera mais abrangente, mas concomitante a isso, relativos às realidades singulares. Nesse ponto, faz-se necessário acrescentar uma observação colocada por Mannheim sobre considerar verdadeira a afirmação de que os conhecimentos advêm de uma única fonte de constituição ou, pior do que isso, considerar que não são influenciáveis por outros tipos de conhecimentos. Em outras palavras, os conhecimentos não estão desvinculados do contexto em que são produzidos, pois recebem influência e dependem da presença de diversas esferas.

Além disso, Mannheim (1972, p.288) explica e define que

A Sociologia do Conhecimento é, por um lado, uma teoria e, por outro, um método histórico-sociológico de pesquisa. Enquanto teoria pode assumir duas formas. É, em primeiro lugar, uma investigação puramente empírica, através da descrição e análise estrutural das maneiras pelas quais as relações sociais influenciam, de fato, o pensamento. 
O que deve levar, em segundo lugar, a uma inquirição epistemológica voltada para o significado desta inter-relação para o problema da validade. É importante notar que esses dois tipos de indagação não estão necessariamente ligados, podendo-se aceitar os resultados empíricos sem se tirar as conclusões epistemológicas.

No caso do presente texto, a primeira posição que a teoria pode assumir se aproxima mais das intenções de investigar a produção e o uso do conhecimento em contextos socioculturais de ambientes organizacionais, pois se trata de uma investigação empírica e não recai sobre a validade atribuída à relação entre, por um lado, o contexto sociocultural e histórico e, por outro, o conhecimento produzido. Nesse caso, é necessário acrescentar que o posicionamento defendido é que o conhecimento organizacional está completamente imerso e dependente da realidade em que é produzido.

A realidade, assim como o conhecimento, é um produto social. “E, na medida em que todo 'conhecimento' humano desenvolve-se, transmite-se e mantém-se em situações sociais, a Sociologia do Conhecimento deve procurar compreender o processo pelo qual isso se realiza”. Esse posicionamento é atribuído a Berger \& Luckmann (2004, p.14), que defendem também que o interesse da sociologia do conhecimento recai sobre a análise da construção social da realidade, e que o processo de construção de conhecimento está na aceitação e incorporação dessa realidade.

É de interesse das investigações voltadas ao conhecimento em ambientes organizacionais competitivos que se estabeleçam métodos e bases teóricas que defendam a existência entre as relações sociais e a influência que essas exercem sobre o conhecimento. Os estudos sobre a realidade organizacional estão presentes em certa medida nas investigações socioculturais.

O conhecimento é, em primeiro lugar, um produto do ambiente em que é construído. $\mathrm{E}$, em segundo, um produto cognitivo dos sujeitos. Assim, possui elementos intangíveis e inerentes a quem o produziu, bem como elementos que pertencem ao ambiente, pois estão presentes em uma base comum e, por isso, subjacentes àque- 
les sujeitos que no ambiente estão incorporados. $\mathrm{O}$ ambiente no qual o conhecimento está situado pode incorporar aspectos mais abrangentes como o econômico, ou aspectos particulares como próprios à trajetória histórica e às combinações realizadas a partir da perspectiva tomada como correta pela organização, ou seja, depende também do interesse e dos aspectos socioculturais institucionalizados no grupo.

Em linhas gerais, no ambiente organizacional empresarial, o conhecimento segue tendência semelhante, uma vez que está condicionado ao ambiente, especialmente no que diz respeito à estrutura em que é produzido. Além disso, depende dos interpostos e outras formas institucionalizadas e compartilhadas de controle sobre a construção de conhecimento, as quais delimitam e direcionam os interesses de quem realiza a produção de conhecimento.

O conhecimento organizacional, considerado para o interesse do presente texto, ganha ares mais gerais quando colocado em relação ao conhecimento individual. Porém, não se limita ao somatório de todos os conhecimentos individuais dos sujeitos da organização. Mas antes, uma estrutura hierárquica elaborada de conhecimentos específicos, produzidos de acordo com o interesse de cada nível estrutural da organização, cuja relação com o ambiente externo, esfera mais englobante e relativa à qual os conhecimentos são produzidos, perde efeito imediato na medida em que se aproxima da base da estrutura organizacional. Dessa forma, os contextos sociais, econômicos, políticos e tecnológicos relativos ao ambiente externo influenciam de maneiras diferentes cada uma das partes da estrutura. Pode-se concluir que, no que tange aos aspectos socioculturais, a influência também pode ser distinta para cada nível da estrutura.

Faz-se necessário, todavia, acrescentar o problema descrito por Engels (apud Elias, 2008, p.519) em relação à afirmativa sobre a suprema influência da esfera econômica na constituição do conhecimento. Como resposta, Engels sugere que isso só seria passível de aceitar tendo em vista a incapacidade de encontrar regularidades em outras esferas, pois essas são absolutamente desestruturadas e fruto de acidentes. 
Sem a intenção de provocar grandes desvios, buscando minimizar erros de interpretação, pretende-se demonstrar que a sociologia do conhecimento pode assumir posição de base teórica, especificamente no que diz respeito ao seu método, que aqui chamaremos também de abordagem, para estudos no ambiente sociocultural empresarial, uma vez que os estudos voltados a esse ambiente ultrapassaram há muito tempo questões direcionadas apenas ao controle sobre a produtividade material, ideia bastante difundida na época de Frederick Wislon Taylor. O direcionamento atual das investigações se dá especialmente sobre a produção, a organização e o uso de conhecimento em ambientes sociais mais restritos, como ocorre nos ambientes socioculturais, tecnológicos e informacionais das organizações.

Partindo da premissa de que a sociologia do conhecimento se propõe a realizar um mapeamento contextualizado e estruturado das ideias (historicizado), bem como da determinação das imbricações entre linhas de pensamento e o contexto de sua produção, pressupõe-se que permita avaliar conhecimentos estabelecidos e existentes em grupos organizacionais, pois também produzem de acordo com determinada história, contextualizando e relativizando o conhecimento. Partindo desse posicionamento, indaga-se sobre a viabilidade de aplicar o método da sociologia do conhecimento, do ponto de vista teórico, para avaliar cenários socioculturais. Em outras palavras, as propostas de método de clássicos dessa área, como Mannheim, Merton, Berger e Luckmann, podem auxiliar a avaliar os conhecimentos e linhas de pensamento no ambiente organizacional? Torna-se imperioso discutir sobre o uso dessa base teórica em contextos de gestão, próximos à realidade organizacional situada em ambientes empresariais competitivos, cuja aplicação se desloca para ambientes organizacionais diferentes das propostas iniciais de aplicação da sociologia do conhecimento, como um método para investigar conhecimentos e linhas de argumentação de teóricos e cientistas, denominados de intelligensia, bem como de conhecimentos formados no cotidiano (Elias, 2008, p.517). Com o intuito de fundamentar tal proposta, apresenta-se uma breve revisão dos posicio- 
namentos de alguns teóricos sobre os precedentes históricos e as bases teóricas da sociologia do conhecimento.

\section{Precedentes históricos da sociologia do conhecimento}

A sociologia do conhecimento recebeu em suas bases teóricas contribuições da filosofia e da sociologia. Elias (2008, p.516) chama a atenção para o que é pressuposto e comumente encontrado nas teorias que formam a base da sociologia do conhecimento. Mostra que se trata de uma afirmação, ainda que sucinta, de que conhecimentos ou ideias são determinados pela "estrutura dos grupos humanos pelos quais são produzidos, não pelos 'objetos' da consciência ou pela própria consciência, chamemos a isso 'lógica', 'razão' ou o que quer que seja". Para a sociologia do conhecimento, o conhecimento não pode ser um produto apenas da razão. Segue nessa mesma linha de argumentação autores como Mannheim, um dos principais teóricos das bases da sociologia do conhecimento, cujas ideias são retomadas no próximo tópico.

O primeiro uso do termo adveio da filosofia. Wissenssoziologie ou sociologia do conhecimento foi o nome atribuído pelo filósofo alemão Max Scheler, na década de 1920. Scheler propôs uma noção não historicista e menos dinâmica ou estruturada da sociologia do conhecimento.

Outras três correntes do pensamento alemão do século XIX se sobressaem como fundamento à sociologia do conhecimento: o marxismo, cuja afirmação recai sobre a determinação da consciência pela sociedade, relação expressa pelos conceitos de estrutura e superestrutura (trabalho e relações produzidas pelo trabalho), bem como se encontram presentes a noção de ideologia, entendida como arma, e a noção de falsa consciência, representando o pensamento alienado. A corrente nietzchiana, transportada para a sociologia do conhecimento, trouxe a proposição de que o conhecimento ou pensamento é um instrumento de poder e de sobrevivência; além disso, a "arte 


\section{MARTA VALENTIM (ORG.)}

da desconfiança" é outro ponto presente na base da sociologia do conhecimento e que tem origem nas afirmações do pensamento de Nietzche. Por fim, a corrente historicista é atribuída a Dilthey (Berger \& Luckmann, 2004, p.16-19). Hegel também é mencionado como teórico do historicismo. De acordo com Mannheim (1982, p.140), "A teoria historicista só preenche sua própria essência quando consegue retirar dessa aparente anarquia de mudanças um princípio de ordenação - quando consegue penetrar na estrutura profunda dessa mudança que tudo abrange".

Trata-se, antes de tudo, de um método que visa ordenar uma análise histórica vertical, obtendo as mudanças sucessivas em cada corrente de pensamento, bem como realiza uma análise transversal ao realizar a correlação entre os conhecimentos, linhas ou fatos socioculturais situados. Tais conhecimentos, linhas ou fatos apresentam-se em influência mútua. Desse modo, a intenção última é obter o padrão de mutação e a estrutura que dá sustentação e equilíbrio à realidade na qual o conhecimento é gerado (ibidem, p.141).

Posicionamentos que consideram a influência decisiva do ambiente social são indispensáveis para admitir os pressupostos da sociologia do conhecimento. Autores como Mannheim, Berger e Luckmann estão engajados com tal posicionamento. Posições absolutistas não são bem-vindas, pois não conseguem sustentar questionamentos sobre a construção de conhecimento, a partir de implicações empíricas e menos racionais, isoladas da realidade.

As principais transformações da sociologia do conhecimento correspondem à mudança de ênfase que na primeira geração recaía sobre a estrutura social e que a partir da segunda de deslocou para os indivíduos.

A despeito dessas qualificações, a segunda geração da sociologia do conhecimento é diferente da primeira em suas ênfases, particularmente quatro. Em primeiro lugar, a ênfase passou da aquisição e transmissão de conhecimento para sua "construção", "produção" ou mesmo "manufatura”, mudança que faz parte de uma inclinação pós-estruturalista ou pós-moderna na sociologia e em outras disciplinas. Há menos insis- 
tência sobre a estrutura social e mais sobre os indivíduos, sobre a linguagem e sobre práticas como a classificação e o experimento. Há menos ênfase na economia e mais na política do conhecimento e nos "detentores do conhecimento". (Burke, 2003, p.17)

Percebe-se que tais mudanças na sociologia do conhecimento refletem a mudança de perspectiva ocorrida também em outras áreas. A teoria geral da administração, mencionada anteriormente na introdução, demonstra uma gradativa mudança de perspectiva semelhante, onde o foco de determinadas teorias passou a enfatizar as pessoas como cerne das organizações.

Todos os teóricos apresentados tornaram possível o aparecimentos da sociologia do conhecimento como um reconhecimento da existência da realidade e em relação à qual o conhecimento é determinado.

\section{As bases da sociologia do conhecimento}

Mannheim propôs bases para a sociologia do conhecimento a partir da ideia de constelação, tomando-a como um conceito central. A constelação é uma categoria ou forma de interpretar o "mundo e a mente humana". Torna-se, dessa forma, bastante útil para estudar a história do pensamento, exigindo considerar não apenas os problemas teóricos, mas também os problemas referentes à vida prática sempre inseridos e existentes em um contexto histórico dinâmico. A constelação constitui-se no problema da sociologia do conhecimento, considerada por Mannheim como uma categoria e um conjunto de quatro fatores, que deixam claro os motivos para o surgimento do problema.

O primeiro fator refere-se a quais são os produtos mentais submetidos à análise, ocupa a posição de segunda pergunta e se subdivide em esferas e aspectos analisados:

a. esferas de: crenças morais, ideologias, ideias, categorias de pensamento, filosofia, crenças religiosas, normas sociais, ciências positivas, tecnologia etc.; 


\section{MARTA VALENTIM (ORG.)}

b. aspectos analisados: sua seleção (foco de atenção), nível de abstração, pressupostos (o que é considerado como "dado" e o que é considerado "problemático"), conteúdos conceituais, modelos de verificação, objetivos da atividade intelectual etc., ascendência ou autorrelativização. Relativizar o pensamento é considerá-lo subordinado a algo mais englobante, descobrir a que estrutura social tal pensamento está subordinado. Não se trata, portanto, de negar a validade.

O desmascaramento, denominado também de "desmascaradora mudança de realidade", é o segundo fator importante para a formação da constelação. Seu sentido é determinar em função do que a ideia é exercida. Nesse caso, a intenção é desintegrar ou destruir a eficácia das ideias. Não se trata de negar a verdade de uma ideia, mas demonstrar a função que ela exerce, verificando sobre a veracidade do que a ideia estabelece e que institui como verdade, ou seja, determinar para o que ela trabalha. Não existe uma tentativa de refutar a ideia, mas destruir suas intenções. O desmascaramento pode ocorrer sobre uma mentira ou sobre uma ideologia. É sobre este último que ocorre o tipo pretendido pela sociologia.

O terceiro fator que forma a constelação é a esfera social. Essa assume o posto de esfera ontológica para a constituição do pensamento. A transferência de esferas como da religiosa para a esfera social e histórica permitiu ao fator econômico assumir o ponto de referência central, pois, antes de tudo, constitui a realidade e o fator mais englobante, e nesse caso passou a representar o ponto de referência para a relativização do conhecimento.

Um exame sobre a totalidade das ideias e não de ideias desconexas ou isoladas da realidade social constitui o quarto fator. Para Mannheim (1962, p.25) essa totalidade de visões de mundo (Weltanschaung) é "ligada a, e determinada por, um estágio do desenvolvimento da realidade social".

Em suma, os quatro fatores que formam a constelação para o problema da sociologia do conhecimento são:

1) a autorrelativização do pensamento e do conhecimento; 
2) o aparecimento de uma nova forma de relativização introduzida pela mudança de mentalidade "desmascaradora";

3) a emergência de um novo sistema de referência, o da esfera social, a respeito do qual o pensamento poderia ser concebido como relativo;

4) a aspiração de tornar essa relativização total, relacionando não um pensamento ou ideia, mas todo um sistema de ideias a uma realidade social subjacente. (ibidem, p.25)

As bases da sociologia do conhecimento buscam, antes de tudo, formular uma proposta para interpretar o mundo. As linhas teóricas mais importantes para a sociologia do conhecimento são o positivismo, o apriorismo formal, o apriorismo material (escola fenomenológica moderna) e o historicismo (ibidem, p.32). Segundo Mannheim (1962, p.34), o positivismo proporcionou o movimento que originou, do ponto de vista filosófico, a transferência, citada anteriormente, com relação à mudança do centro de referência da esfera religiosa para a esfera econômica e social, além disso, tornou a metafísica impossível.

O apriorismo formal, neokantismo ou filosofia da validade formal, deposita a atenção sobre o pensamento, depreciando o Ser. Nesse sentido, "a filosofia da validade deprecia o Ser, como se oposto ao Pensamento, em amplitude equivalente a uma declaração de completo desinteresse pelo Ser" (ibidem, p.34). A validade do conhecimento que um sujeito adquire independe de seus aspectos psicológicos. Antes estão depositados sobre aspectos lógico-objetivos (Abbagnano, 2003, p.710).

O apriorismo material (fenomenologia moderna) é mostrado por Mannheim a partir da posição assumida por Max Scheler, o qual se constitui em posição contrária e adversa à de Mannheim em diversos aspectos, mas especialmente no que tange a atribuição de atemporalidade às ideias e à compreensão que lança sobre as fases do processo. Utiliza aspectos próximos à ciência natural, uma vez que intenta estabelecer regras e leis para o processo social (Mannheim, 1962, p.41). O principal a considerar na visão fenomenológica da sociologia do conhecimento de Scheler é o fato de ser possível 
"apreender supratemporalmente verdades válidas em 'intuição essencial' (Wesensschaun)" (ibidem, p.38). Também consta a separação fenomenológica que ele realiza entre mental e real, considerando que os fatores mentais são determinantes sobre os reais. Nesse caso, os fatores reais são marginalizados, deixando de explicar situações que demonstram claramente como os fatores reais determinam os mentais. Para Mannheim, os fatores reais e os mentais influenciam-se concomitantemente em um processo histórico, sem que exista prevalência de um sobre o outro, ao que ele chama de "totalidade genética dinâmica”.

A perspectiva é tomada como essencial para compreender os contextos de significação. Cada contexto só pode ser compreendido se levado em conta todo o contexto de significação, ou seja, deve-se considerar a totalidade e não um elemento isoladamente. Além disso, a compreensão recai também sobre a base de origem do elemento de significação. "Assim, um ato de compreensão consiste em incorporar um 'elemento de significação' estranho ao nosso próprio contexto de significação, cancelando suas relações funcionais originais e introduzindo-o dentro de nosso próprio-padrão de função" (ibidem, p.55).

O historicismo, por sua vez, busca tornar evidente o que significa cada fato histórico. O real e o ideal existem a partir de um processo mútuo de interação e interdependência, não se constituindo como possível uma lei geral de sucessão que explique de maneira ordenada as ideias. Antes, é preferível falar de uma sequência definida temporalmente de fatos singulares.

A sociologia do conhecimento é composta de tarefas. A descoberta da correlação entre correntes de pensamento e posições sociais constitui-se numa primeira tarefa (ibidem, p.70).

prestar contas as mais exatas possíveis das posições intelectuais que coexistem num dado momento, e de retraçar seu desenvolvimento histórico, pois até as posições individuais como tais não são "estáticas", permanecendo imutáveis do começo ao fim; ao contrário, ofluxo inexorável do processo histórico traz dados sempre novos à superfície, que pedem 
interpretação e podem levar a uma desintegração ou modificação dos sistemas previamente existentes. (ibidem, p.64)

Assumindo a posição de segunda tarefa, encontra-se o ato de compreender e explicar o papel funcional do pensamento, das ideias, do ponto de vista social e existencial em suas fases sequenciais. Tratase de um processo social e existencial significativo.

Resta ainda mencionar que o conhecimento está condicionado também à estratificação presente na realidade. Nesse caso, cada estrato produz e perpetua ideias com características diferenciadas. Tornar evidente que cada fato histórico possui um significado e promover a explicação das conexões que existem entre o conhecimento, a existência, a vida social e a realidade é um percurso que traz maior segurança para a devida compreensão e análise de ideias, utopias ou pensamentos de determinados grupos.

Além disso, a origem de um conhecimento ou sua incorporação por um estrato ou grupo social resulta do interesse e do comprometimento com as ideias. O comprometimento é uma esfera mais geral do que o interesse, e isso o leva se tornar mais significativo para a sociologia do conhecimento.

é uma das características mais marcantes da história que um determinado sistema econômico esteja sempre inserido, pelo menos quanto à sua origem, em determinado universo intelectual de tal maneira que os que buscam uma determinada ordem econômica também buscam uma visão intelectual a ela correlata. Quando um grupo está diretamente interessado em um sistema econômico, está indiretamente "comprometido" com as demais formas intelectuais, artísticas, filosóficas etc., que lhe correspondem. Dessa maneira, o "comprometimento" indireto com determinadas formas mentais é a categoria mais global no campo do condicionamento social das ideias. (ibidem, p.72)

Por fim, é necessário comentar que, quando uma ideia, um conhecimento ou uma utopia é perpetuada em um grupo qualquer, isso pode significar a existência de uma mudança de função de tal ideia, de modo que a essa se acrescentam aspectos que podem 
modificá-la completa ou parcialmente. Tomando como exemplo a visão de que no início da era industrial os trabalhadores eram considerados apenas como uma força de trabalho e extensão das máquinas, percebe-se que atualmente tal perspectiva foi em grande parte modificada. Os trabalhadores atuais são também fonte de conhecimento organizacional, uma vez que realizam a produção de conhecimentos. Desse modo, à ideia de trabalhador é atribuído um significado diferente, portanto constatando uma mudança de caráter sociológico e não apenas imanente (mudança pertencente ao mundo das ideias, quando essas passam de um sistema de ideias para outro).

Com o intuito de chegar à resposta sobre a viabilidade de aplicar o método da sociologia do conhecimento, do ponto de vista teórico, para avaliar cenários socioculturais, propõe-se trazer algumas das ideias mais importantes de Berger e Luckmann, e demonstrar os problemas metodológicos discutidos do ponto de vista de Merton.

\section{Método na sociologia do conhecimento}

Além da proposta de Mannheim ao estabelecer os passos, entendidos como de aplicação, da sociologia do conhecimento, outros teóricos também propuseram bases a essa área, com abordagens que se distinguiram em vários aspectos, por exemplo, como se verifica nas discussões sobre a maneira de se conduzir a perspectiva adotada de acordo com a origem do conhecimento, buscando subsidiar ideias fundamentadas na condição de o conhecimento ser vinculado ou não a alguma base existencial empírica. Entretanto, apesar da variedade de abordagens, algumas linhas de argumentação são bastante recorrentes, como as noções de Mannheim, que por sua vez se fundamentou em parte no marxismo, entre outras bases. A maioria das abordagens indica como parte do problema da sociologia do conhecimento a construção do conhecimento nas ciências.

Merton (1967, p.87) propõe um modelo analítico para as diversas abordagens, divergências, problemas defendidos e consequências imediatas nas principais linhas teóricas que constituem a socio- 
logia do conhecimento. O modelo se perfaz de cinco pontos que prometem desenvolver de forma analítica a sociologia do conhecimento. Porém, em nosso entendimento, o modelo de Merton apresenta um sentido restrito de aplicação, se aplicado apenas sobre o conhecimento científico e não sobre o conhecimento do cotidiano.

O primeiro versa sobre investigar "onde se situam as bases existenciais dos produtos mentais", buscando respostas em relação a duas bases diferentes. Quais sejam:

a. bases sociais: posição social, classe, geração, papel ocupacional, modo de produção, estruturas de grupo (universidade, burocracia, academias, seitas, partido político), "situação histórica", interesses, sociedade, filiação étnica, mobilidade social, estrutura de poder, processos sociais (competição, conflito etc.);

b. bases culturais: valores, ethos, "clima de opinião", Volkgeist, Zeitgeist, tipo de cultura, mentalidade cultural, visão de mundo (Weltanschauungen) etc. (Merton, 1967, p.87)

"Quais são os produtos mentais submetidos à análise", ocupa a segunda posição nas perguntas e se subdivide em esferas e aspectos analisados.

a. esferas de: crenças morais, ideologias, ideias, categorias de pensamento, filosofia, crenças religiosas, normas sociais, ciências positivas, tecnologia etc.;

b. aspectos analisados: sua seleção (foco de atenção), nível de abstração, pressupostos (o que é considerado como "dado" e o que é considerado "problemático"), conteúdos conceituais, modelos de verificação, objetivos da atividade intelectual etc. (ibidem, p.87)

A indagação sobre "como se acham os produtos mentais relacionados às bases existenciais” é para Merton (1967, p.87-8) uma questão de determinar o tipo de relação, ou seja, se a relação é causal ou funcional; simbólica, expressiva ou orgânica; e, por último, distinguir que termos são usados para efetuar referência às relações. Nesse caso, a terceira pergunta se desmembra em três aspectos. 
a. relações causais ou funcionais: determinação, causa, correspondência, condição necessária, condicionamento, interdependência funcional, interação, dependência etc.;

b. relações simbólicas, expressivas ou orgânicas: consistência, compatibilidade (e antônimos); expressão, percepção, expressão simbólica, Strukturzusammenhang, identidades estruturais, conexões internas, analogias estilísticas, integração lógico significativa, identidade de significado etc.;

c. termos ambíguos para designar as relações: correspondência, reflexos, ligados a, em estreita conexão com etc. (ibidem, p.88)

O quarto componente que contribui para o modelo de Merton, e que se apresenta semelhante à ideia da "desmascaradora mudança de realidade" de Mannheim, é resumido na seguinte pergunta: Por quê? E traduzida em: quais são as "funções latentes e manifestas atribuídas a esses produtos mentais existencialmente condicionados?". De acordo com Merton (1967, p.88), a possível resposta à pergunta pode ser:

a. para manter poder, promover estabilidade, facilitar orientação ou exploração, ocultar relações sociais efetivas, fornecer motivações, canalizar comportamentos, desviar críticas, desviar hostilidades, tranquilizar, controlar a natureza, coordenar relações sociais etc.

A última questão que auxilia a formar o modelo analítico de Merton busca responder "quando se evidenciam as relações atribuídas entre a base existencial e o conhecimento", estabelecendo duas linhas teóricas de orientação para a resposta. A primeira é a historicista e a segunda é fundamentada em teorias analíticas mais gerais (ibidem).

O problema da proposta de Merton é que numa primeira leitura nos parece restringir sua aplicação à análise de conhecimentos e ideias de linhas teóricas, cujas representações estão nos principais autores da sociologia do conhecimento. Sua proposta se distancia, em princípio, de uma aplicação intencional e próxima ao ambiente organizacional cujo intuito é analisar os conhecimentos que pertencem aos 
estratos da estrutura. Contudo, a nosso ver, o modelo também pode ser transportado, se mantidas as devidas diferenças de aplicação, ao contexto empresarial.

Nesse sentido, as quatro primeiras questões podem servir de instrumento de investigação e análise do conhecimento produzido e utilizado no ambiente organizacional, uma vez que perfaz a relação entre o conhecimento e o contexto sociocultural. Quanto à última questão, serve de base teórica orientadora geral, ao apresentar duas linhas de sustentação, e a linha historicista aponta soluções mais consistentes com o contexto específico sociocultural das empresas.

\section{Considerações finais}

Realizou-se no presente texto uma breve explanação sobre a origem, as bases de constituição da sociologia do conhecimento, bem como a exposição de um dos métodos aplicados a esta área.

A contribuição da sociologia do conhecimento se dá em relação à maneira de perceber o conhecimento como um produto complexo e situado e cujos construção e uso podem ser alterados conforme o momento histórico ao qual pertence e, sobretudo, pelas esferas às quais são referências para a construção. Ou seja, pode-se fazer uso da sociologia do conhecimento como base teórica orientadora para interpretar a realidade organizacional. Por um lado, admite-se que a influência maior se dá pelo ambiente externo organizacional, sobretudo sobre a esfera econômica; e, por outro, existe a influência dos fatores intrínsecos à organização. Além disso, a contribuição da sociologia do conhecimento para estudos sobre a construção do conhecimento em ambientes organizacionais se dá especialmente com relação ao método empregado, tomando como exemplo o método analítico de Merton, cuja orientação não se distancia da proposta de Mannheim, pelo menos no que diz respeito ao conteúdo das ideias.

Propondo adequar a análise do conhecimento produzido na ciência pela sociologia do conhecimento, empregado à realidade empresarial, são estabelecidas algumas questões a título de instrumento 
orientador. Permeiam esse instrumento as teorias subjacentes à sociologia do conhecimento, mencionadas em tópicos anteriores. Nesse sentido, como uma proposta inicial de tradução do modelo de Merton, apresentam-se questões que podem se constituir em base para a construção de um modelo de avaliação do conhecimento no ambiente organizacional.

- Que tipos de conhecimentos são produzidos em cada nível? Quais são os interesses subjacentes ao produzi-los? Com o que as pessoas estão comprometidas no processo de construção de conhecimento? Por que são construídos? Possuem relação com a base sociocultural? Qual a relação do conhecimento produzido com a base sociocultural e estrutural encontrada no ambiente organizacional? Quais são as esferas (esferas mais gerais e elementos culturais) influentes na construção? Quais são os aspectos (modelos etc.) mais influentes? Quais são as ideologias presentes na organização? Quando surgirame a quem são destinadas? Existem mudanças de função das ideologias desde sua origem? Por que mudaram? Existe relação entre a mudança de ideologia e a mudança da cultura da organização?

Esse esboço de instrumento apresenta uma proposta clara de verificar a relação do conhecimento com a realidade organizacional, especialmente no que diz respeito às esferas mais influentes, estabelecendo parâmetros para a avaliação do processo de construção de conhecimento. Além disso, são questões orientadas a verificar sobre a relação entre as classes ou estratos sociais e a produção do conhecimento, bem como se tais classes são adeptas ou não às políticas organizacionais de produção de conhecimento.

Adotar uma configuração dinâmica para o conhecimento torna-se uma estratégia de explicação necessária, mas, como nos lembra Elias (2008), ela deve contemplar também a ideia de que os conhecimentos se desenvolvem e são acumulados. Essa noção de acumulação e desenvolvimento sustenta a ideia de conhecimento organizacional como um tipo de conhecimento composto de conhecimentos individuais dos sujeitos que nela atuam, somados, perpetuados e modificados. Mas que assume uma forma quase hipostasiada e autônoma aos indi- 
víduos. Portanto, realizar a análise de tal conhecimento é buscar compreender o processo histórico e em relação a que base existencial é criado.

\section{Referências}

ABBAGNANO, N. Neocriticismo. In: Dicionário de Filosofia. São Paulo: Martins Fontes, 2003.

BERGER, P. L.; LUCKMANN, T. A construção social da realidade: tratado de sociologia do conhecimento. 24.ed. Petrópolis: Vozes, 2004.248p.

BURKE, P. Sociologias e histórias do conhecimento: introdução. In: Uma história social do conhecimento: de Gutenberg a Diderot. Rio de Janeiro: Zahar, 2003. p.11-24.

ELIAS, N. Sociologia do conhecimento: novas perspectivas. Sociedade e Estado, Brasília, v.23, n.3, p.515-54, set./dez. 2008.

MANNHEIM, K. O problema de uma sociologia do conhecimento. In: BERTELLI, A. R. et al. (Org.) Sociologia do conhecimento. Rio de Janeiro: Zahar, 1967. p.13-80

A sociologia do conhecimento. In: Ideologia e utopia.

2.ed. Rio de Janeiro: Zahar, 1972. 330p.

Conhecimento e sociedade. In: MANNHEIM, K. Sociologia. São Paulo: Ática, 1982. p.96-151.

MERTON, R. K. Sociologia do conhecimento. In: BERTELLI, A. R. et al. (Org.) Sociologia do conhecimento. Rio de Janeiro: Zahar, 1967. p.81-125. 



\section{6 \\ Modelo de COMPORTAMENTO INFORMACIONAL DE USUÁRIOS: UMA ABORDAGEM TEÓRICA}

Rodrigo Octávio Beton Matta

\section{Introdução}

O presente capítulo trata do papel da ciência da informação e dos estudos desenvolvidos por essa ciência em relação aos usuários de informação, trazendo uma visão geral da importância de se estudar os usuários e seus comportamentos informacionais e a possibilidade de uso de conhecimentos sobre comportamento humano no desenvolvimento de pesquisas nesse tema.

O homem é um ser em constante mudança. Dotado de grande complexidade, não se limita a manter um mesmo tipo de pensamento por toda a vida. Não raramente, as pessoas sentem necessidade de mudar o seu comportamento em uma determinada área.

Pessoas que enfrentam dificuldades no processo de mudança de comportamento podem necessitar do auxílio de familiares, amigos e, não raramente, de profissionais especializados, como psicólogos, psiquiatras e assistentes sociais, pois a mudança comportamental envolve diversos aspectos, com destaque para os psicológicos, os sociológicos e os informacionais.

Os aspectos psicológicos abrangem pensamentos, conflitos interiores, visão do mundo e do problema enfrentado, sentimentos diante da vida e da situação enfrentada, estágios vividos durante o 
processo de mudança comportamental; enfim, envolvem os aspectos interiores e individuais na busca pela mudança.

Os aspectos sociológicos decorrem do fato de que o homem é um ser social e a sociedade exerce influência significativa nos indivíduos, sejam essas influências positivas, sejam negativas. Sociologicamente, a preocupação é voltada para a condição social da pessoa antes, durante e após a mudança de comportamento desejada, procurando solucionar possíveis conflitos e inseri-lo novamente na sociedade se for o caso.

Quanto aos aspectos informacionais, é fato que todos os envolvidos em um processo de mudança de comportamento necessitam, buscam e utilizam informações para que seja possível o alcance dos objetivos perseguidos. Aquele que deseja a mudança é carente de informações que o motive e sanem seus questionamentos a respeito do assunto e das dificuldades por ventura enfrentadas.

Sendo assim, em todo o processo de mudança de comportamento, a informação aparece como elemento essencial para os envolvidos. Ante a complexidade do assunto, é importante que a ciência esteja em constante busca de conhecimentos que possam auxiliar as pessoas e demais envolvidos a obterem sucesso em uma mudança comportamental desejada. Nesse quadro, a ciência da informação não pode se eximir de sua responsabilidade e deve apresentar sua visão e contribuições para o tema.

\section{A ciência da informação e o estudo de comportamento dos usuários de informação}

A ciência da informação, de caráter interdisciplinar, "tem por objetivo o estudo das propriedades gerais da informação (natureza, gênese, efeitos)" (Le Coadic, 2004, p.25). Essa ciência também estuda o ciclo da informação que consiste em três fases: a construção da informação, a comunicação e o uso (ibidem).

Robredo (2003, p.5) afirma que 
Ciência da Informação é a disciplina que investiga as propriedades e o comportamento da informação, as forças que regem o fluxo da informação e os meios de processamento da informação para um máximo de acessibilidade e uso. $O$ processo inclui a origem, disseminação, coleta, armazenamento, recuperação, interpretação e uso da informação. $\mathrm{O}$ campo deriva ou relaciona-se com a matemática, a lógica, a linguística, a psicologia, a tecnologia computacional, as operações de pesquisa, as artes gráficas, as comunicações, a biblioteconomia, a gestão e alguns outros campos.

Questões relativas à gestão das informações, como acessá-las, armazená-las e difundi-las são discutidas pelos estudiosos da área de ciência da informação, pois é sabido que os sistemas de informação, por si só, não são suficientes para responder às demandas informacionais das pessoas, das empresas e da sociedade em geral. Acredita-se que:

- a informação não é facilmente arquivada em computadores - e não é constituída apenas de dados;

- quanto mais complexo o modelo de informação, menor será a sua utilidade;

- a informação pode ter muitos significados em uma organização;

- a tecnologia é apenas um dos componentes do ambiente de informação e freqüentemente não se apresenta como meio adequado para operar mudanças. (Davenport, 1998, p.14)

Nesse cenário, a ciência da informação surge como uma ciência interdisciplinar, com grande potencial de crescimento e de influência nas demais ciências, pois o seu objeto de pesquisa, a informação, é matéria-prima de todas as demais ciências e atividades humanas.

Muito se discute sobre as definições de termos como dado, informação e conhecimento. Le Coadic (2004, p.4) afirma que a informação consiste em "um conhecimento inscrito (registrado) em forma escrita (impressa ou digital), oral ou audiovisual, em um suporte”. Já dados são, segundo Davenport (1998, p.19), "observações sobre o estado do mundo”, ou, ainda, "em informática, dado é a representação 
convencional, codificada, de uma informação em uma forma que permita submetê-la a processamento eletrônico" (Le Coadic, 2004, p.8).

Urdaneta (1992) apresenta uma definição mais detalhada a respeito da informação e afirma que ela pode ser classificada em quatro níveis que são representados por meio da pirâmide informacional, a saber: dado, informação, conhecimento e inteligência. Dadoé definido como informação como matéria. É o estado bruto da informação. Os dados são os ícones, os símbolos, sejam eles fonéticos ou numéricos, que são os canais pelos quais se representam conceitos e instruções. O pesquisador define informação como um significado. Neste momento, a informação traz consigo um potencial significativo, um sentido que possui uma relevância. $O$ dado por si só pouco representa, já a informação traz a qualidade de um significado. No entanto, os conteúdos informacionais podem crescer em seu significado, atingindo a classificação de conhecimento. $\mathrm{O}$ conhecimento consiste na informação como compreensão. Tal qualidade do conteúdo informacional é atingida quando a informação se une à compreensão sobre o que ela significa em um determinado ambiente. Por fim, a inteligência é atingida quando o conhecimento é aplicado como oportunidade. Resulta da capacidade de se retirar do conhecimento uma atitude ou intervenção que seja vantajosa perante a realidade.

Entende-se que tão importante quanto estudar o objeto "informação" é o estudo daqueles que a utilizam. Entender seus hábitos, pensamentos, necessidades e atitudes diante da informação tornouse uma linha de pesquisa da ciência da informação.

O estudo de usuários é "uma investigação que objetiva identificar e caracterizar os interesses, as necessidades e os hábitos de uso de informação dos usuários reais e/ou potenciais de um sistema de informação" (Silva, 1990, p.80). Figueiredo (1994, p.7) define estudo de usuários como "investigações que se fazem para saber o que os indivíduos precisam em matéria de informação, ou, então, para saber se as necessidades de informação por parte dos usuários de uma biblioteca ou de um centro de informação estão sendo satisfeitas de maneira adequada". 
Segundo Izquierdo Alonzo (1999, p.113), os estudos de usuários ganham importância com o passar dos anos evidenciados pela

proliferação da literatura, a progressiva inclusão desse tipo de estudo nos planos de estudos das universidades e a assídua presença do tema usuários nos fóruns de debates das associações profissionais onde são apresentados perguntas, problemas e expectativas que devem abordar o estudo sistemático do usuário.

Essa reconhecida importância gerou aumento nas pesquisas envolvendo o assunto. Pode-se afirmar que os estudos envolvendo usuários da informação possuem dois grandes enfoques ou paradigmas. O paradigma centrado no sistema e o centrado no usuário.

Estudos centrados no sistema são aqueles nos quais existe a "premissa de que as necessidades de informação podem ser expressas ou reformuladas em questões, de acordo com a linguagem do sistema" (Figueiredo, 1999, p.13). Tais estudos possuem uma visão que situa o usuário como um ser passivo que deve se adaptar ao sistema de modo a alcançar o conteúdo informacional desejado. Entende-se que cabe ao usuário adaptar-se ao sistema, qualificando-se no entendimento do funcionamento ou lógica de busca de dados nos sistemas.

Quanto ao paradigma centrado no usuário, Figueiredo (1999) expõe que esse paradigma preocupa-se com a individualidade de cada pessoa. Em vez de disponibilizar uma série de informações e desenvolver um método de busca de informações, pensando nos aspectos tecnológicos de um sistema ou de características puramente sociológicas dos usuários, procura-se entender qual o caminho percorrido pelas pessoas na busca pela informação. A necessidade de informação não é única, comum a todos os indivíduos, mas própria e específica de cada um deles. Procura-se dar atenção maior a entender como os usuários processam a informação do que ao desenvolvimento do sistema em si e a inserção de novas tecnologias.

Com essa visão, os estudiosos da ciência da informação passaram a inserir conteúdos e teorias de outras áreas do conhecimento, 
como a psicologia, o que propiciou o desenvolvimento mais aprofundado dos estudos de usuários que passaram a focar não apenas os aspectos tradicionais de uso, busca e necessidade de informação, mas também os aspectos e as características pessoais e coletivas dos usuários em torno da informação. Começa-se, então, o interesse por estudos mais completos em relação aos usuários da informação, e surgem com maior incidência pesquisas envolvendo o chamado comportamento informacional.

Comportamento informacional é definido por Wilson (1999, p.249) como "as atividades a que uma pessoa se dedica quando está identificando suas necessidades de informação, procurando por quais caminhos sejam essas informações e usando ou transferindo essa informação" (tradução nossa).

Costa \& Gasque (2004, p.1) afirmam que os assuntos que normalmente são tratados nas pesquisas sobre comportamento informacional abordam:

- necessidades de informação - um déficit de informação a ser preenchido e que pode estar relacionado com motivos psicológicos, afetivos e cognitivos;

- busca da informação - ativa e/ou passiva - o modo como as pessoas buscam informações;

- uso da informação - a maneira como as pessoas utilizam a informação;

- fatores que influenciam o comportamento informacional;

- transferência da informação - o fluxo de informações entre as pessoas;

- estudos dos métodos - identificação dos métodos mais adequados a serem aplicados nas pesquisas.

Sayão (2001, p.82) afirma que "Os cientistas, hoje em dia, apercebem-se do fato de que todas as suas teorias são criações da mente humana; são propriedades do nosso mapa mental da realidade, e não pertencentes ao domínio da realidade”.

Deduz-se dessa afirmação que a realidade é muito complexa e que a mente humana procura gerar protótipos e cenários que sim- 
plifiquem a realidade e possibilitem a sua explicação de um modo inteligível. Diante disso, o mesmo pesquisador afirma que

um modelo é uma criação cultural, um "mentefato", destinada a representar uma realidade, ou alguns dos seus aspectos, a fim de torná-los descritíveis qualitativa e quantitativamente, algumas vezes, observáveis. A existência de modelos jaz na impossibilidade cultural de descrever os objetos com perfeição, esgotando as possibilidades de sua observação. (ibidem, p.83)

Diante dessa realidade, alguns modelos foram construídos e procuram entender o comportamento informacional dos usuários de informação. Entre os modelos existentes, pode-se destacar, não exaustivamente, o modelo expandido de Wilson (1999) e o modelo de Kuhlthau, mais conhecido como Information Search Process (ISP).

Thomas D. Wilson desenvolveu o seu primeiro modelo de comportamento informacional em 1981 e propôs uma nova reflexão, na realidade uma expansão do seu próprio modelo em 1996.

Ao tentar explicar a realidade do comportamento informacional do usuário em 1981, Wilson alerta para que se tome cuidado na identificação de uma necessidade informacional, já que as necessidades informacionais não são aquelas necessidades de imediato visíveis, mas, sim, frutos das verdadeiras fontes de necessidades, classificadas por ele como básicas, que podem ser classificadas como fisiológicas, cognitivas ou afetivas.

Outro aspecto trazido pelo primeiro modelo de Wilson diz respeito aos tipos de barreiras que podem ser encontradas pelos usuários durante o seu esforço em satisfazer as suas necessidades informacionais. Essas barreiras podem advir de contextos de ordem pessoal, ambiental ou do papel social e interpessoal do usuário da informação e influenciam na busca de satisfação de suas necessidades de informação, conforme ilustra a Figura 1: 
Contexto da necessidade de informação

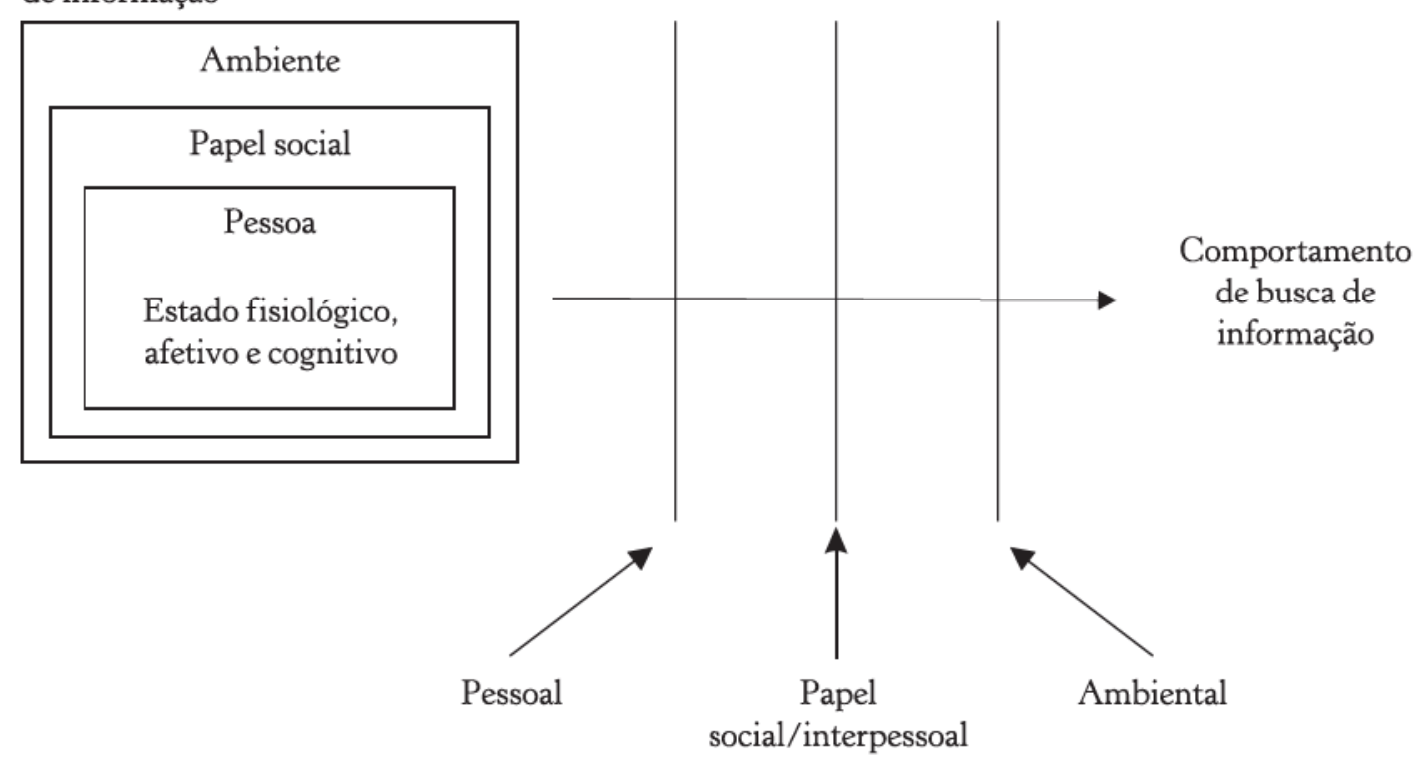

Figura 1 - Modelo de comportamento informacional de Wilson (1981, tradução nossa).

Apesar da aceitabilidade do seu modelo, Wilson notou que ele precisava de alguns ajustes, pois o modelo considerava apenas aspectos implícitos, excluindo-se os impactos que o contexto externo pode ter nas pessoas e os diferentes impactos que as barreiras podem desempenhar.

Sendo assim, Wilson desenvolveu uma ampliação do seu modelo original que ficou conhecido como modelo de comportamento informacional complexo. O pesquisador manteve o foco do estudo do comportamento no usuário, porém passou a tratar as barreiras como variáveis interferentes.

O novo modelo de Wilson é representado pela Figura 2: 


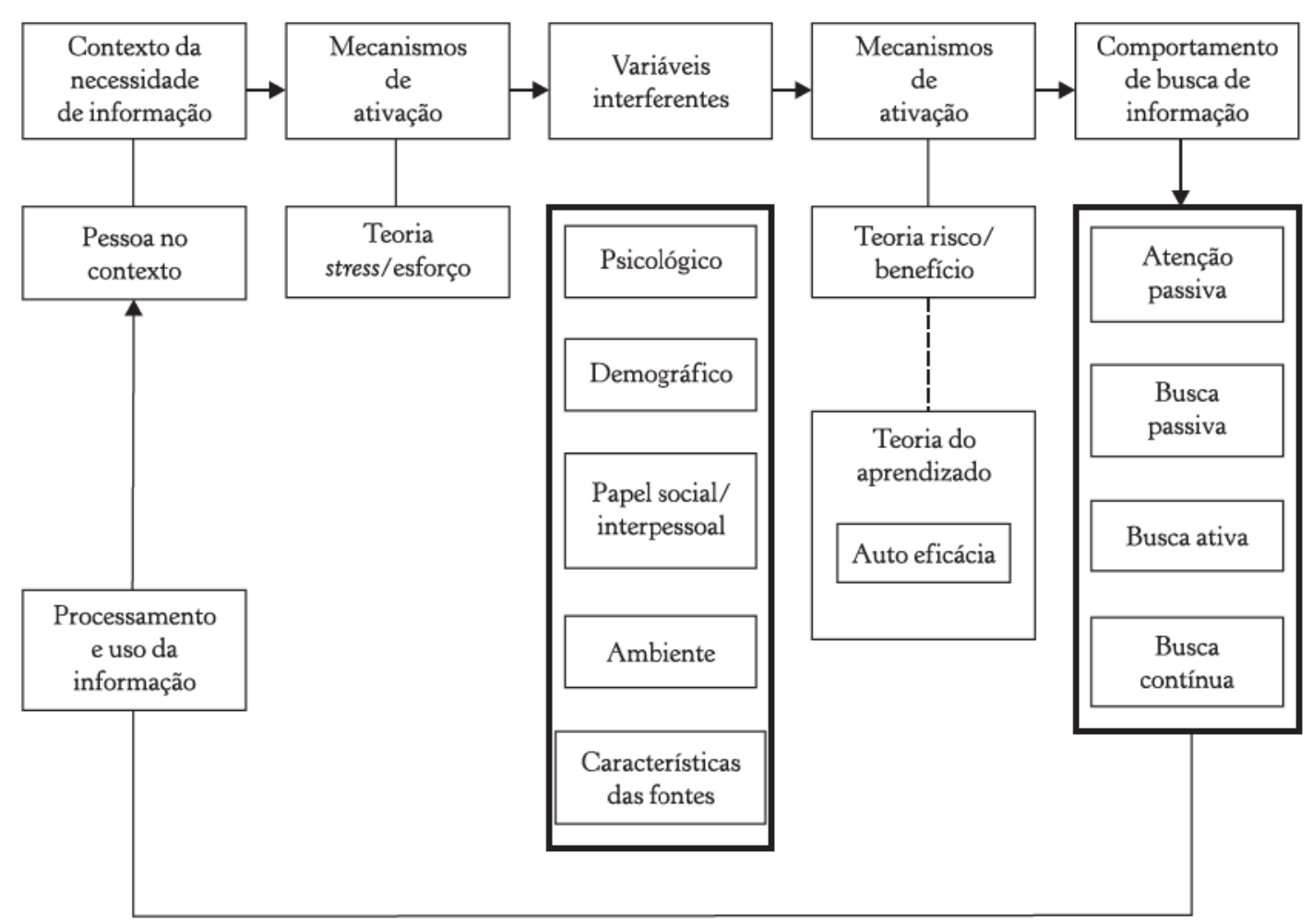

Figura 2 - Modelo de comportamento informacional de Wilson (1996, tradução nossa).

Dessa forma, buscou o pesquisador exemplificar de modo mais completo o comportamento informacional de uma pessoa levando em conta a complexidade que envolve o tema.

Já o modelo ISP de Kuhlthau (1991) surgiu de trabalhos de campo em que se estudou o comportamento de busca de estudantes universitários e usuários de bibliotecas. Kuhlthau (1991)identificou seis estágios (iniciação, seleção, exploração, formulação, coleta e apresentação) porque um usuário em busca de informação passa e buscou estabelecer nessas fases pensamentos, sentimentos, ações e as tarefas recomendadas para cada estágio na busca de informação. Um resumo do modelo é demonstrado pelo Quadro 1.

Tais modelos descritos no Quadro 1 consistem em exemplos do esforço científico empregado no entendimento do comportamento informacional dos usuários. Tal esforço acaba por contribuir para o melhor entendimento dos usuários de informação, e com isso possibilita o fornecimento de insumos aos profissionais da informação, 


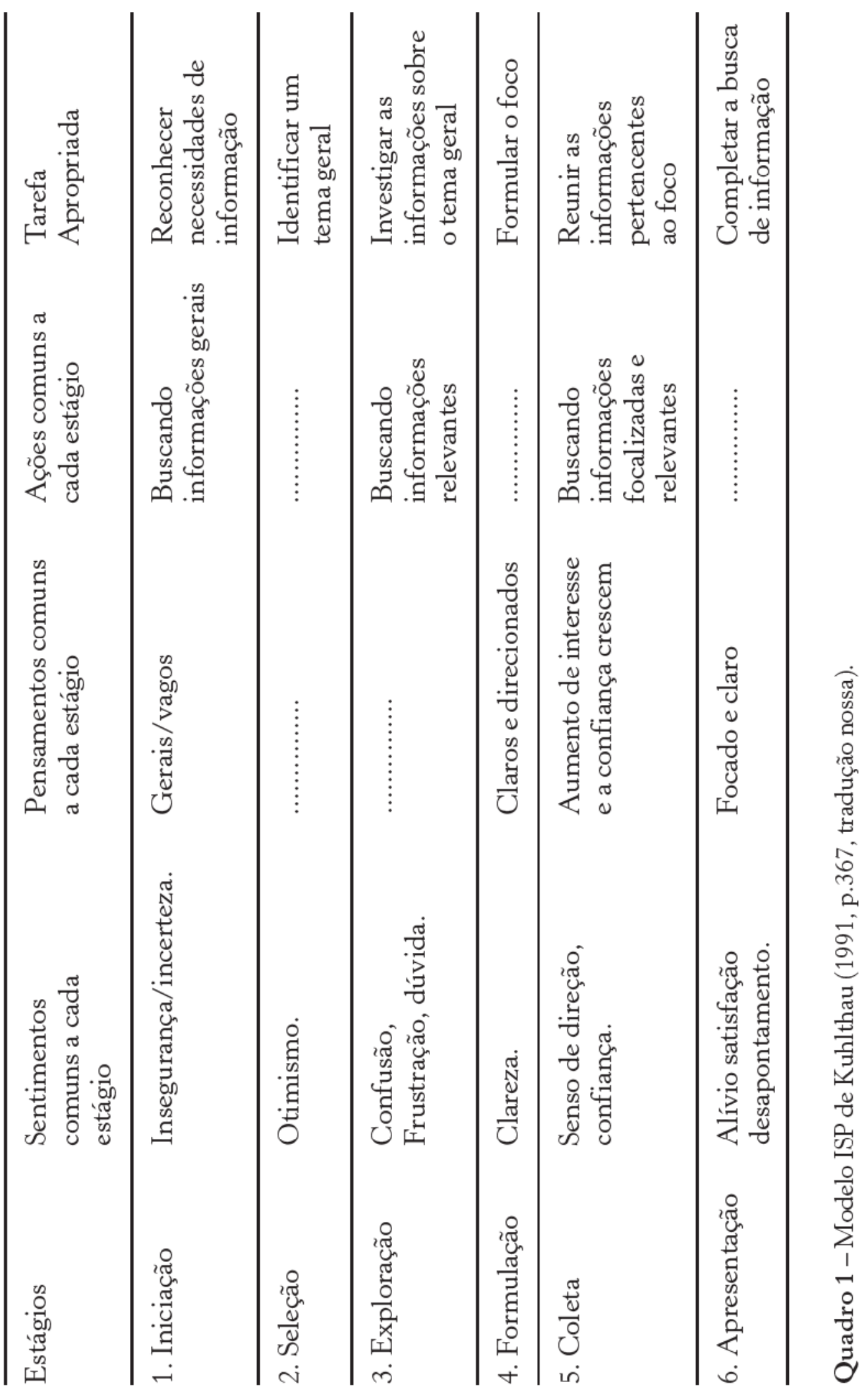


para que seja possível a maximização da gestão informacional, no momento em que se conhece a forma como os usuários se comportam diante das suas necessidades e buscas informacionais.

\section{Comportamento informacional aplicado ao cotidiano e o modelo transteórico de mudança de comportamento}

Cotidianamente, as pessoas sentem-se necessitadas de informação que as ajude a solucionar os problemas cotidianos da vida. Nãoé pelo fato de que um usuário não está envolvido em uma atividade formal de busca de informação ou inserido em um contexto organizacional que ele não possui atitudes e comportamentos de busca informacional. É necessário que haja a real percepção de que a informação é o principal elemento da sociedade atual. Continuamente as pessoas estão em busca de informações que sejam úteis em todos os aspectos de sua vida, sejam esses de cunho familiar, profissional e, especialmente, pessoal.

Felizmente, alguns pesquisadores estão conscientes desse fato e desenvolvem estudos que buscam expressar o comportamento informacional dos usuários nas diversas situações cotidianas que eles enfrentam. Como exemplos, têm-se os estudos que Reijo Savolainen desenvolveu na década de 1990. O pesquisador desenvolveu um modelo de comportamento informacional denominado busca de informação na vida cotidiana (Every Day Life Information Seeking). Tal modelo objetiva a representação do comportamento informacional das pessoas quando no desenvolvimento das atividades do seu cotidiano, incluindo aí as atividades específicas de estudo e trabalho.

O modelo de Savolainen (1995) apresenta o conceito de modo de vida (way of life) que pode ser entendido como a manifestação prática do habitus que se apresenta "como um determinado sistema cultural e social de pensamento, percepção e avaliação internalizada pelo indivíduo” (Savolainen, 2005, p.143). 


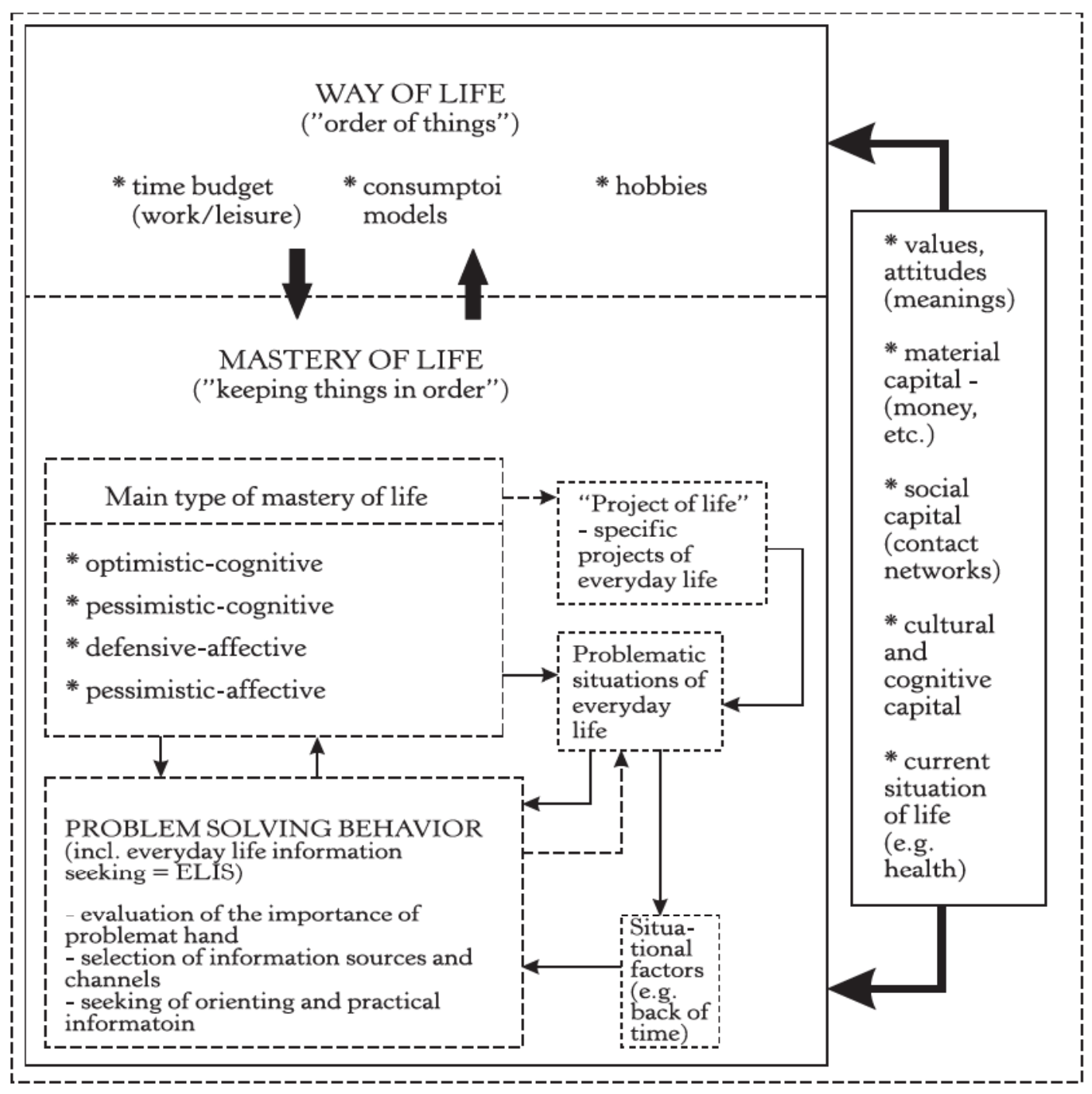

Figura 3 - Modelo ELIS (Savolainen, 2005, p.145).

Tal conceito é tido como fator básico no comportamento informacional das pessoas eé entendido como algo existente na cognição das pessoas e representada pela ordem das coisas (orders of things). Savolainen (2005, p.144) explica o termo.

"Coisas" referem-se a várias atividades que ocupam lugar no mundo cotidiano, incluindo não apenas o trabalho, mas também as tarefas de reprodução necessárias como atividades domésticas e atividades voluntárias (hobbies); "ordem" refere-se às preferências dadas a essas atividades. Correspondentemente, as pessoas possuem uma "ordem cognitiva" indicando suas percepções de como as coisas são quando estão "normais". 
Os estudos de comportamento informacional recorrem constantemente às teorias do campo da psicologia e o seu entendimento do comportamento humano para que se entendam os usuários de informação. Prochaska et al. (1994), estudiosos e profissionais do campo da psicologia, afirmam que, para que haja uma mudança de comportamento, é necessário que as pessoas possuam estratégias e determinem um plano que as direcione pelo caminho a ser percorrido, de modo que seja possível sair de um comportamento indesejado para um novo comportamento. Segundo os autores, independentemente de qual for a estratégia traçada por alguém, uma mudança de comportamento leva o indivíduo a passar por vários estágios. Esses estágios da mudança comportamental são definidos no modelo transteórico de mudança de comportamento de Prochaska et al. (1994). Afirmam os autores que são cinco os estágios experimentados pelos indivíduos durante a mudança comportamental, a saber:

a) Pré-contemplação: estágio em que a pessoa não possui consciência de um determinado problema ou não lhe dá importância suficiente para que seja iniciada uma tentativa de mudança de atitude. Pessoas do seu convívio enxergam a necessidade de mudança, mas elas mesmas não se dispõem a mudar e normalmente não querem lidar com o problema.

b) Contemplação: nesse estágio a pessoa identifica o problema e inicia uma discussão (interna e/ou externa) a respeito da necessidade de mudar. A pessoa sabe a direção que necessita tomar, porém ainda não se vê apta para enfrentar a mudança. Caracterizado por uma indecisão entre os prós e os contras de se manter o comportamento atual.

c) Preparação: momento em que existe uma determinação de iniciar o processo de mudança. Tem-se clara consciência da necessidade de mudança e que é o caminho mais vantajoso para si. Inicia a definição de estratégias e de como irá conseguir mudar o seu comportamento.

d) Ação: normalmente, esse é o estágio em que a decisão de mudança de comportamento é exteriorizada em forma de atitudes con- 
cretas e pode ser observado por outras pessoas. Apesar de ser considerado um estágio de grande desafio, é esse o momento em que se pode encontrar reconhecimento por parte de outras pessoas do esforço que se está realizando. Nesse estágio existem duas possibilidades: recair para o comportamento antigo ou manter com sucesso o novo comportamento.

e) Manutenção: estágio em que se busca não perder o que foi conquistado no estágio anterior. É a manutenção do desejo de mudança. Momento que exige o maior esforço e atenção para prevenir lapsos e relapsos que levem ao comportamento antigo indesejado.

O modelo transteórico de mudança de comportamento tem sido testado, revisado e aperfeiçoado por meio de vários estudos empíricos e atualmente é utilizado por diversos profissionais em todo o mundo (Prochaska et al., 1994). É importante salientar que "o modelo tem sido estudado em uma série de populações com diferentes tipos de comportamentos e mostra capacidade de integração com outras teorias" (Oliveira et al., 2003, p.2). Tal afirmativa é significativa, pois reitera a importância desse modelo não apenas para estudos psicológicos, mas também para subsidiar a criação de outros modelos nos mais diversos campos da ciência.

\section{Considerações finais}

Ante o exposto, verifica-se que os estudos voltados ao comportamento informacional dos usuários de informação são dotados de grande característica interdisciplinar, assim como sugere ser a própria ciência da informação.

O modelo transteórico de mudança de comportamento de Prochaska et al. (1994) traz a oportunidade de se olhar o usuário da informação sob uma óptica inovadora. Se as pessoas passam por estágios durante a sua tentativa de mudança comportamental e durante esses estágios as pessoas apresentam características psicológi- 
cas e sociais próprias de cada estágio como aponta tal modelo, é provável que o uso, a busca, as necessidades informacionais e os comportamentos diante da informação dessas pessoas sejam também alterados e específicos em cada um desses estágios.

Sendo assim um estudo para desenvolver um modelo de comportamento informacional sob a óptica do modelo transteórico de mudança de comportamento possibilita uma sinergia entre a psicologia e a ciência da informação. Isso porque se, por um lado, tal estudo tem o potencial de ser um valioso complemento a esse modelo da psicologia sob a óptica da ciência da informação, por outro, a ciência da informação adquire um novo modo de estudar os usuários de informação, atentando para as características comportamentais dos seus usuários dentro da realidade e do momento específico de vida em que se encontram.

\section{Referências}

COSTA, S. M. de S.; GASQUE, K. C. G. D. Comportamento dos professores da educação básica na busca da informação para formação continuada. Ciência da Informação, Brasília, v.32, n.3, p.54-61, 2003.

DAVENPORT, T. H. Ecologia da informação: por que só a tecnologia não basta para o sucesso na era da informação. 6.ed. São Paulo: Futura, 1998.

FIGUEIREDO, N. M. Estudo de uso e usuários de informação. Brasília: IBICT, 1994.

Paradigmas modernos da ciência da informação. São Paulo: Polis; APB, 1999. 168p.

IZQUIERDO ALONZO, M. Una aproximación interdisciplinar al estudio del usuario de información: bases conceptuales y metodológicas. Investigación Bibliotecológica, México, D. F., v.13, n.26, p.11234, ene./jun. 1999. Disponível em: <http:// www.ejournal.unam.mx/iibiblio/vol13-26/IBI02608.pdf > . Acesso em: 4 de jul. 2009.

KUHLTHAU, C. C. Inside the search process: information seeking from the user's perspective. Journal of the American Society for Information Science, Washington, v.42, n.5, p.361-71, 1991. 
LE COADIC, Y.-F. A ciência da informação. 2.ed. Brasília: Briquet de Lemos, 2004.

OLIVEIRA, et al. Estudo dos estágios motivacionais em sujeitos adultos dependentes do álcool. Psicologia, Reflexões Críticas, Porto Alegre, v.16, n.2, 2003.

PROCHASKA, J. O. et al. Changing for good: a revolutionary six-stage program for overcoming bad habits and moving your life positively forward. New York: Avon, 1994.

ROBREDO, J. Da ciência da informação revisitada aos sistemas humanos de informação. Brasília: Thesaurus; SSRR Informações, 2003. 262p.

SAVOLAINEN, R. Everyday life information seeking: approaching information seeing in the context of way of life. Library and Information Science Research, n.17, p.259-94, 1995.

Everyday life information seeking. In: FISHER, K. E.; ERDELEZ, S.; McKECHNIE. Theories of information behavior. New Jersey: ASIS\&T, 2005. p.143-8.

SAYÃO, L. F. Modelos teóricos em Ciência da Informação: abstração e método científico. Ciência da informação, Brasília, v.30, n.1, p.8291, jan./abr. 2001.

SILVA, E. L. Sistema de informação e mensuração da demanda da informação: análise de uso e estudos de usuários de literatura. Revista de Biblioteconomia de Brasília, v.18, n.1, p.71-91, jan./jun. 1990.

URDANETA, I. P. Gestión de la inteligência, aprendizaje tecnológico y modernización del trabajo informacional: retos y oportunidades. Caracas: Instituto del Conocimiento de la Universidad Simon Bolívar, 1992.

WILSON, T. D. On user studies and information needs. Journal of Documentation, v.37, n.1, p.3-15, 1981.

Models in information behavior research. Journal of Documentation, London, v.55, n.3, p.249-70, Jun. 1999. 


\section{7 \\ TECNOLOGIAS DE INFORMAÇÃO E COMUNICAÇÃO PARA GESTÃO DA INFORMAÇÃO E DO CONHECIMENTO: PROPOSTA DE UMA ESTRUTURA TECNOLÓGICA APLICADA AOS PORTAIS CORPORATIVOS}

Letícia Gorri Molina

\section{Introdução}

O homem está em constante transformação, e durante a sua evolução tem desenvolvido técnicas que o auxiliam a se comunicar de forma mais rápida, eficiente e consistente, além de possibilitar diferentes formas de registro da informação que produz. Nas sociedades antigas, a informação era transmitida de forma oral. Com o passar do tempo e de acordo com as necessidades do homem, diferentes formas de escrita foram sendo criadas conforme sua evolução e a sociedade na qual estivesse inserida. Assim, no decorrer da história da humanidade, a informação foi registrada em distintos suportes, como pedra, mármore, argila, papiro, pergaminho, papel e, mais recentemente, em suportes digitais.

Revoluções aconteceram, e com elas surgiram transformações quanto ao modo de pensar e agir do ser humano. Com o surgimento e o desenvolvimento da informática, os conhecimentos especializados, gerados pelo homem, começaram a formar grandes bancos de dados e informação, "capazes defazer automaticamente algumas conexões pertinentes entre as representações, mais ou menos como se compreendesse seu sentido” (Lévy, 1993, p.108-9), mas que terão suas limitações, pela própria estrutura que os sistemas computadorizados apresentam. 
Apesar dessas limitações, esses bancos de dados e informação, se adequadamente estruturados, fornecem informação relevante para quem o está acessando e, portanto, auxiliam na construção do conhecimento por parte do usuário. Nesse sentido, defende-se a importância de a informação digital ser gerenciada eficientemente pelos sistemas de informação corporativos, com o objetivo de propiciar o acesso e a recuperação de dados e informação consistentes, bem como que sua utilização seja transformada em conhecimento e em vantagem competitiva.

Diante de um mundo informacional inserido no paradigma das Tecnologias de Informação e Comunicação(TICs), as organizações são protagonistas de um ambiente que se caracteriza por uma grande produção informacional, e que precisa ser organizada para seu acesso e uso. Assim, a informação precisa ser gerenciada, com vistas à construção do conhecimento organizacional e, como consequência, a possibilidade de a organização responder mais rapidamente às demandas de um mercado em constante transformação.

Na literatura encontramos, muitas vezes, uma visão reducionista em relação à gestão do conhecimento, porquanto é considerada uma simples atividade de gestão. No entanto, é necessário que a gestão do conhecimento seja entendida a partir de uma visão sistêmica e complexa, considerando o sujeito na sua totalidade, ou seja, como um ser cultural, social, cognitivo etc. Outro aspecto importante está relacionado à percepção do sujeito cognoscente em relação ao seu entorno, visto que éa partir de suas conexões cognitivas que ele constrói conhecimento.

Quanto mais o indivíduo estiver conectado ao meio em que vive, assim como quanto mais acesso às informações ele obtiver, maior é a possibilidade de ele estruturar as "memórias do futuro", estabelecendo novas e diferentes conexões com o que o indivíduo possui internalizado, criando assim novo conhecimento.

Nesse sentido, o estudo e o estabelecimento de um modelo de gestão da informação e do conhecimento em portais corporativos se fazem necessários, visto que esse tipo de gestão possibilita trabalhar a informação com valor agregado, podendo auxiliar enormemente a 
organização, quanto a acesso, recuperação e disseminação da informação, assim como na construção de conhecimento por parte de seus colaboradores.

\section{Organizações}

As empresas necessitaram criar mecanismos para tornarem-se mais flexíveis, dinâmicas e, consequentemente, mais competitivas, com maiores possibilidades de sobrevivência em um mercado em constante mudança.

As empresas com maior poder de sobrevivência estão atentas às mudanças ocorridas em seu entorno, para mudarem também; constroem uma identidade própria; estabelecem relacionamentos além das suas estruturas; apresentam independência e capacidade no direcionamento do seu crescimento e da sua evolução, não ficando dependentes somente do governo e das políticas públicas estabelecidas por esse.

Em relação às mudanças que irão ocorrer na nova sociedade, segundo Peter Drucker (2002, p.35)

é, em parte, a nova tecnologia, como computadores, vídeos e transmissões via satélite; em parte as demandas de uma sociedade baseada em conhecimento, na qual a aprendizagem organizada deve se tornar um processo ao longo da vida para os trabalhadores intelectuais; e, em parte, a nova teoria sobre como os seres humanos aprendem.

Nesse ambiente, o processo estará focado no homem e nas suas formas de relação com o trabalho e a tecnologia, suas formas de aprendizagem e aquisição de conhecimento. Essa nova sociedade se estabelecerá tendo como base o desenvolvimento e uso das tecnologias de informação, e como o homem irá utilizá-las no seu dia a dia e nas novas formas de produção decorrentes dessa relação, que são voltadas mais para o uso da aprendizagem e da inteligência humana.

Mais do que nunca, o século XXI será dominado por essa nova concepção de organização do trabalho, em que a produção, antes 
focada no processo, passa a se concentrar nas pessoas e no seu conhecimento, "o conhecimento tomou o lugar do capital como fator escasso de produção - a chave do sucesso corporativo. Aqueles que possuíam conhecimento e sabiam como aplicá-lo passaram a ser, a partir de então, os membros mais ricos da sociedade..." (Geus, 1998, p.5).

São as pessoas que passam a ser importantes nos processos de trabalho, e o uso que elas fazem do conhecimento que possuem, pois conhecimento que não é aplicado não traz desenvolvimento, nem é fator de competitividade.

Nesse processo, a capacidade da empresa em desenvolver seus processos tecnológicos informacionais, que envolvam a geração e uso do conhecimento, garantirá sua competitividade no mercado. $\mathrm{O}$ modo informacional de desenvolvimento organizacional utiliza a informação como base de desenvolvimento da sociedade, voltado tanto aos aspectos sociais quanto aos organizacionais.

Toda empresa é capaz de produzir conhecimento, porém ela só será eficiente se for capaz de transformar esse conhecimento em ação. O conhecimento gerado internamente à organização, quando é objeto de gestão, subsidia as ações e os processos estratégicos que auxiliam a organização na sua atuação no mercado. Com o surgimento da "Era do Conhecimento", os processos de trabalho tornam-se mais complexos, há necessidade de se criar novas formas de estruturas, estratégias e processos organizacionais. Diante desse ambiente, e

para enfrentar um mundo em constante mudança, qualquer entidade precisa desenvolver a capacidade de migrar e mudar, de desenvolver novas habilidades e atitudes: em resumo, a capacidade de aprender [...] a essência do ato de aprender é a capacidade de gerir a mudança mediante a mudança em si mesmo - tanto para as pessoas, quando se tornam adultas, como para as empresas, quando vivenciam o mundo. (Geus, 1998, p.7)

Para tanto, a empresa precisa conhecer sua estrutura, suas potencialidades (física e humana) e o ambiente em que está inserida. 
Só assim será capaz de saber por quê, quando e como mudar. Além disso, a organização precisa se tornar mais flexível para mover-se no mercado internacionalizado.

Diante das transformações ocorridas no meio organizacional, a informação adquiriu um papel econômico, pois se tornou insumo ao desenvolvimento de produtos, à captação de recursos, ao conhecimento de mercado e à própria sobrevivência das empresas. Assim, "numa economia de informação, a concorrência entre as organizações baseia-se em sua capacidade de adquirir, tratar, interpretar e utilizar a informação de forma eficaz" (McGee \& Prusak, 1994, p.3).

Além do valor monetário que a informação passou a representar para uma determinada organização, em relação à sua situação no mercado e sua competitividade, há uma supervalorização em relação ao conhecimento gerado em âmbito organizacional, visto ser esse o insumo para a inovação.

\section{Tecnologias de informação e comunicação utilizadas no processo de gestão da informação}

Com o grande volume de informação produzida interna e externamente à organização, a Gestão da Informação (GI) assume um papel preponderante na busca, no controle e no uso da informação. Assim, ela tem como foco o negócio da organização, e sua ação é restrita aos fluxos formais de informação (Valentim, 2002), uma vez que a gestão da informação trabalha no âmbito do conhecimento explícito, isto é, com a informação formal e estruturada, tanto interna quanto externa à organização.

Nesse contexto, é preciso estabelecer procedimentos para coleta, tratamento e uso da informação, assim como para o seu ciclo de vida, visto que o universo informacional é dinâmico, ou seja, se desatualiza e se transforma.

Ponjuán Dante (2004, p.17) define GI como um processo, 
mediante el cual se obtienen, despliegan o utilizan recursos básicos (económicos, físicos, humanos, materiales) para manejar información dentro y para la sociedad a la que sirve. Tiene como elemento básico la gestión del ciclo de vida de este recurso y ocurre en cualquier organización.

A autora defende que a GI tem como objetivo coleta, tratamento e disseminação de informação útil à organização, assim como aos usuários, utilizando-se das estruturas físicas, tecnológicas e humanas existentes na organização. Além disso, esse tipo de gestão necessita observar atentamente o tipo de informação que a organização necessita, assim como o ciclo de vida dessa informação, visto que, além de o meio organizacional sofrer modificações, a própria informação também passa por esse processo.

Além disso, não se pode perder o foco, como defende Tarapanoff (2001, p.44):

o principal objetivo da gestão da informação é identificar e potencializar os recursos informacionais de uma organização e sua capacidade de informação, ensiná-la a aprender e adaptar-se às mudanças ambientais. A criação da informação, aquisição, armazenamento, análise e uso provêem a estrutura para o suporte ao crescimento e desenvolvimento de uma organização inteligente, adaptada às exigências e às novidades da ambiência em que se encontra.

Assim, compreende-se que o foco da GI é auxiliar a organização a gerenciar seus conteúdos informacionais, gerados internamente ou não, de forma que o uso da informação seja considerado estratégico. No ambiente organizacional, a informação é considerada um dos subsídios ao processo decisório. "Sob esse prisma, a informação adquire a condição de mensagem e intencionalidade, que determinam a probabilidade de serem assimiladas pelos usuários da empresa..." (Jannuzzi \& Tálamo, 2004, p.181).

Terra e Gordon (2002, p.62) reconhecem que os projetos voltados à GI "têm objetivos técnicos muito específicos, prazos, projetos de fluxo de dados e um estado final detalhado, e normalmente estão 
preocupados com a integridade dos dados e com políticas e estratégias para distribuir informação". De acordo com esses autores, a GI se preocupa com a organização e a disseminação da informação no sentido mais objetivo, e em relação ao fluxo da informação formal gerada pela organização.

Outro aspecto relevante em relação à GI é a atuação das pessoas nesse processo, pois são elas que a estruturam e a colocam em prática. Como defende Ponjuán Dante (2004, p.35) "las personas son las que diseñan los sistemas, las que emplean la tecnología, las que proyectan el desarrollo, las que se comunican con el ambiente e intercambian con él".

O homem é o "recurso" de maior importância no universo organizacional, pois é ele quem projeta, estrutura, implanta e usa todos os processos existentes na organização. Assim, é necessário criar um ambiente interativo, inserindo-o no processo de gestão da informação, de forma que ela ocorra da melhor forma possível.

A sociedade contemporânea caracteriza-se pelo intenso desenvolvimento da ciência e da tecnologia e também por uma forte competição no mercado econômico. É inegável o relevante e fundamental papel das TIC, assim como da informação e conhecimento como principais insumos de desenvolvimento do setor produtivo, científico e acadêmico, constituindo-se como um dos fatores críticos de sucesso desses segmentos econômicos. As TIC revolucionaram a forma como o homem lida com a informação e o conhecimento.

Segundo Oliveira (2003, p.26), a tecnologia é vista "como um conjunto de conhecimentos, práticos ou científicos, aplicados à obtenção, distribuição e comercialização de bens e serviços. Esses produtos não só satisfazem desejos e necessidades, como também substituem, aliviam ou simplificam o esforço físico e mental das pessoas".

As facilidades proporcionadas pelos avanços das TIC, tanto em relação ao aumento da capacidade de armazenamento, processamento e disseminação de grandes volumes de informações, cada vez mais consistentes, seguros e a custos menores, assim como em relação ao acesso e à recuperação da informação com maior rapidez, confiabilidade e efetividade de resposta, são importantes fatores no desenvolvimento dos sistemas informacionais. 
As TIC devem ser vistas como um recurso importante para coleta, tratamento e disseminação de dados e informação, assim como para a criação de conhecimento, por parte dos integrantes de uma determinada comunidade de especialidade. Também possibilitam mecanismos para criação de comunidades virtuais internas e externas; nesta última, tanto nacionais como internacionais, criando uma rede de relacionamento pessoal e prof issional, que atua de forma eficiente e produz mudanças tanto em relação ao uso da informação quanto em relação à construção de conhecimento, tanto individual quanto coletivo.

Os Sistemas de Informação (SI) são definidos por Laudon \& Laudon (1999, p.4) como "um conjunto de componentes inter-relacionados trabalhando juntos para coletar, recuperar, processar, armazenar e distribuir informação com a finalidade de facilitar o planejamento, o controle, a coordenação, a análise e o processo decisório de empresa e outras organizações".

Esses sistemas auxiliam em gestão, tratamento, armazenamento e disseminação da informação formal, possibilitando sua transformação, codificando-a e tornando-a utilizável pelos usuários dos sistemas.

Laudon \& Laudon (1999, p.208) defendem que o projeto de um SI necessita de alguns componentes básicos para sua estruturação, como:

- Saídas: quais informações serão produzidas pelo sistema, como relatórios e apresentações on-line.

- Entradas: como os dados serão inseridos no sistema, para criar a saída desejada.

- Processamento: quais atividades serão necessárias para que os dados de entrada sejam transformados em dados de saída, istoé, quais as manipulações serão necessárias para que o que foi inserido na entrada tenha a saída desejada.

- Banco de dados: método que organizará e armazenará as informações no sistema, considerando quais dados serão armazenados, quando e como atualizá-los, como será o relacionamento entre eles e como serão organizados. 
- Procedimentos: as atividades que serão executadas pelos usuários finais, assim como pela equipe de operação do sistema, na sua utilização.

- Controles: definição dos processos, tanto manuais quanto automatizados, e os procedimentos que assegurem que o sistema seja seguro e tenha o desempenho requerido.

Esses componentes auxiliam no planejamento e na estruturação adequados do SI: as saídas são os produtos resultantes das análises realizadas pelo sistema, isto é, são as respostas proporcionadas pelo sistema ante uma requisição informacional feita pelo usuário; as entradas estão relacionadas às formas de como a informação será inserida no sistema, e que estão diretamente ligadas às saídas; o processamento são as formas estabelecidas para o tratamento e análises a serem realizados às informações; os bancos de dados são os repositórios que armazenarão as informações, apresentando campos para inserção das informações úteis ao sistema; os procedimentos são as normas e regras estabelecidas para a utilização do sistema, tanto para os usuários quanto para os operadores do sistema; os controles são os processos manuais e automatizados que estabelecem os procedimentos para o funcionamento correto do sistema, assim como de sua segurança.

Consideram-se aqui algumas ferramentas tecnológicas, que tratam da informação no contexto dos fluxos formais da informação organizacional, sendo assim utilizadas para a GI, como: Workflow, Business Intelligence (BI), Enterprise Resouce Planning (ERP), Customer Relationship Management (CRM), Data Warehouse, Data Mining, Text Mining, Gerenciamento Eletrônico de Documentos (GED), Database Marketing (DBM).

Todos esses recursos tecnológicos têm nos bancos e bases de dados e seus relacionamentos sua estrutura básica para armazenamento da informação cujos conteúdos informacionais são decorrentes dos fluxos de informação formais existentes na organização. 


\section{Tecnologias de informação e comunicação utilizadas na gestão do conhecimento}

Estudos e pesquisas têm sido realizados com o intuito de se conhecer melhor o processo de construção do conhecimento organizacional visto, às vezes, de forma reducionista, fato que propicia confundir Gestão do Conhecimento (GC) com Gestão da Informação (GI).

$\mathrm{O}$ conhecimento construído em âmbito organizacional precisa ser gerenciado, visando ao seu compartilhamento/socialização, assim como se torne um ativo para obtenção de vantagem competitiva. Portanto, surge uma nova atividade organizacional denominada "gestão do conhecimento".

Nehmy \& Paim (2003, p.279) defendem que o processo de GC visa tornar explícito e codificado os processos tácitos individuais e coletivos de construção de conhecimento no ambiente organizacional, ou seja, "criar condições para que o conhecimento aflore e seja partilhado em função do interesse da empresa".

Para Terra (2000, p.219-20; Terra \& Gordon, 2002, p. 57), existe um esforço para fazer que o conhecimento corporativo esteja disponível para aqueles que dele necessitem, quando, onde e na forma que se faça necessário, aumentando o desempenho humano e organizacional. Para tanto, é necessário estabelecer processos e estruturas internas à organização, que possibilitem que o conhecimento seja disseminado.

Além disso, tem como desafios: "conectar eficientemente 'aqueles que sabem' com aqueles que 'necessitam saber' e converter conhecimento pessoal em conhecimento da organização" (Stollenwerk, 1999, p.13). Esses desafios são amenizados por meio da estruturação de bancos e bases de conhecimento ou de especialistas, mas não se pode perder de vista a importância do envolvimento e comprometimento das pessoas nesse processo.

Valentim (2006, p.4) defende que a GC tem como foco a inserção do conhecimento tácito no universo do conhecimento explícito, ou seja, lida com os fluxos informais de informação. Assim, em relação aos fluxos informacionais, enquanto a GC "trabalha no âmbi- 
to do não registrado [...] a gestão da informação trabalha no âmbito do registrado" (ibidem, p.1). Essa seria a principal diferença entre gestão do conhecimento e gestão da informação.

Para Santos \& Sant'ana (2002, p.8), o conhecimento tácito, por estar diretamente ligado à mente do sujeito cognoscente, é de difícil acesso e registro em meios artificiais. Já o conhecimento explícito é considerado um iceberg, isto é, é a parte mais superficial do conhecimento humano, visto que apenas um pequeno porcentual do conhecimento humano pode ser convertido em um conjunto de informações e registrado em suportes artificiais.

O conhecimento organizacional, de certa forma, está inserido em processos formais, como normas, relatórios, manuais, patentes, projetos etc., assim como em processos informais, como na experiência individual dos funcionários e na maneira pessoal de cada indivíduo realizar uma atividade. Diante disso, é necessário criar mecanismos que possibilitem a gestão desse conhecimento tácito (processos informais) em explícito (processos formais).

Davenport \& Prusak (2003, p.83) explicam: para que o conhecimento seja adequadamente organizado, com o intuito de futuro acesso e transferência para os usuários e para a organização como um todo, ele deve sofrer um processo de codificação que, de acordo com os autores, significa tornar o conhecimento acessível aos usuários que dele necessitam. A codificação transforma o conhecimento num código (não aquele utilizado de forma computacional), tornando-o inteligível e organizado, convertendo-o em formatos acessíveis e aplicáveis.

Alegam, porém, que

uma vez que a finalidade da codificação é colocar o conhecimento em formato utilizável, a empresa precisa ter uma ideia dos usos possíveis [...] o projeto de codificação do conhecimento necessita de objetivos mais específicos do que simplesmente tornar o conhecimento disponível em âmbito geral. (ibidem, p.84-5)

Para conhecer o ativo intelectual que a organização possui é necessário estruturar bases ou repositórios de conhecimento, que res- 
pondam a questões como: quem faz o quê, qual conhecimento possui, que atividades desenvolve etc. Essa base funcionaria como "páginas amarelas", auxiliando as pessoas a localizarem o que e quem elas procuram.

As estruturas tecnológicas da organização devem ser planejadas e estruturadas de forma que proporcionem coleta, tratamento, armazenamento e disseminação do conhecimento explícito organizacional, pois somente um ambiente rico em informação útil e flexível, tanto em questões físicas quanto tecnológicas, possibilitará a disseminação desse conhecimento explícito, a aquisição pelos indivíduos, e sua transformação em conhecimento tácito.

A sociedade informacional proporciona um ambiente em constante transformação, cuja rapidez influencia enormemente as organizações, e a tecnologia possibilita que elas gerenciem de forma mais eficiente as informações e os conhecimentos corporativos.

As TIC devem ser vistas como um recurso importante para coleta, tratamento e disseminação de dados e informação, assim como para a criação de conhecimento, por parte dos integrantes de uma determinada comunidade de especialidade.

É importante mencionar que o tratamento adequado da informação e do conhecimento corporativo é um dos principais requisitos para a sobrevivência da organização. Com o desenvolvimento das TIC, a informação e o conhecimento podem ser obtidos por diversas fontes, armazenados em diferentes mídias eletrônicas e digitais.

Os recursos das TIC proporcionam maior comunicação e o trabalho em rede. Portanto, o uso adequado proporciona às organizações processos comunicativos que possibilitam o uso efetivo de informação e conhecimento, visto que fazem parte de seus componentes: hardware (computadores e periféricos), software (operacionais, de redes, aplicativos, utilitários, entre outros), sistemas de telecomunicação (transmissão eletrônica de sinais para comunicação), gestão de dados e informações (Rezende \& Abreu, 2006, p.7592). Assim, para que uma organização tenha um uso otimizado dos seus recursos de TIC, ela necessariamente precisa atuar e implantar todos esses componentes, além do componente humano, o qual irá 
utilizar todo esse sistema. "Uma gestão do conhecimento efetiva requer uma solução híbrida, envolvendo pessoas, organização e tecnologia" (Moresi, 2006, p.278).

Como o volume de informação recebida e processada no âmbito organizacional é muito grande, as organizações começaram a estruturar os recursos informáticos, com o objetivo de gerenciar adequadamente esse conteúdo informacional, tanto dos fluxos formais de informação quanto dos fluxos informais.

Parte-se do princípio de que a GC lida com os fluxos informais, isto é, o conhecimento tácito que ainda não foi explicitado em nenhum tipo de suporte físico, visto que são gerados pelo sujeito cognoscente mediante relações que ele estabelece entre as informações que recebe e apreende e os seus próprios conteúdos internalizados. Portanto, a GC trabalha com o conhecimento tácito, isto é, o conhecimento tácito que pode de alguma maneira ser explicitado.

Nesse contexto, os recursos tecnológicos que trabalham com os fluxos formais são denominados de Sistemas de Informação (SI) e estão relacionados à $\mathrm{GI}$; assim como os recursos tecnológicos que trabalham com os fluxos informais são chamados de Sistemas de Conhecimento (SC) e que estão relacionados à GC.

Robredo (2006, p.304) descreve o sistema de GC como apresentando suas vertentes:

a primeira consiste na coleta, estruturação e organização do capital informação (recursos documentais de todo tipo; competências e expertise; propostas, projetos ou ideias formalizados). A segunda visa promover, apoiando-se nessas bases colocadas ao alcance de todos, o intercâmbio, os comentários e as reações que venham a agregar valor ao capital informação/conhecimento, tanto para fundamentar decisões e estratégias quanto para provocar a reflexão prospectiva.

De acordo com o contexto descrito pelo autor, e de levantamento realizado em literatura referente ao tema, encontram-se fazendo parte do sistema de GC: os bancos e as bases de conhecimento, melhores práticas, memória tecnológica, sistemas especialistas, mapas do co- 
nhecimento ou páginas amarelas, e outros tipos de bancos e bases que contenham o registro do conhecimento tácito do indivíduo; assim como recursos e ferramentas tecnológicas que possibilitem o intercâmbio do conhecimento, como o groupware e outros tipos de ferramentas. A seguir, são apresentadas as ferramentas tecnológicas que fazem parte de um SC.

Os SC apresentam uma estrutura de bancos e bases de dados, além de ferramentas tecnológicas que não geram conhecimento por si só, ou seja, de forma independente, como acreditam algumas organizações, visto que esses sistemas precisam da intervenção humana. Já os sistemas humanos, que se utilizam desses sistemas, possuem capacidade e condições física, química e biológica para modificar seu próprio conhecimento, pelo acesso a novas informações, gerando, assim, novos conhecimentos.

Apenas a estruturação física de um SC, porém, não deve ser considerada como resolução do problema em relação ao conhecimento organizacional. Moresi (2006, p.283) defende que "as estruturas significantes armazenadas em bases de dados, arquivos ou memórias organizacionais possuem a competência para produzir conhecimento, mas que só se efetiva a partir de uma ação de comunicação mutuamente consentida entre a fonte e o receptor".

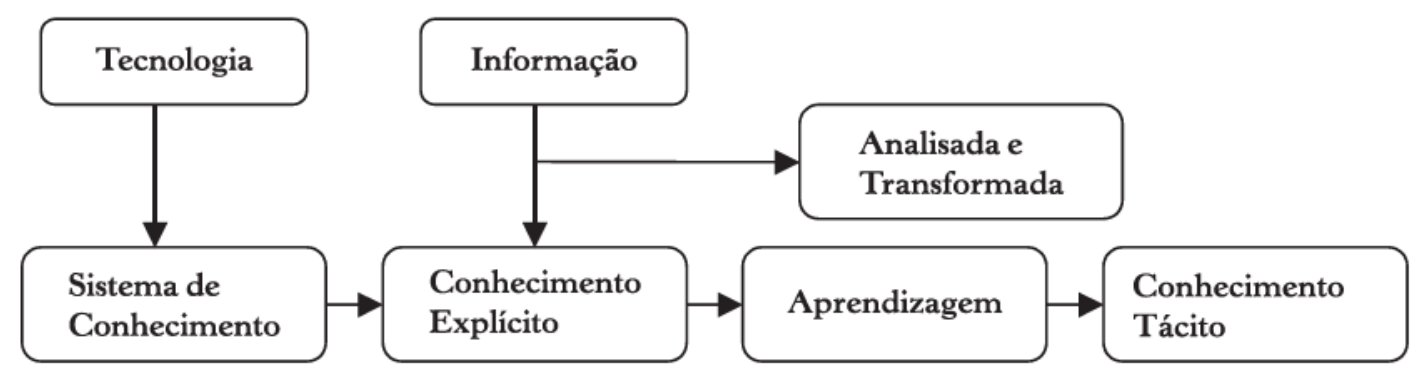

Figura 1 - Sistema de conhecimento e o processo de geração de conhecimento tácito. Fonte: Elaborado pela autora.

Os programas voltados à GC tendem a ser mais efetivos se as organizações consideraram-nos como um processo organizacional contínuo, assim como acreditar que é importante despender tempo e trabalho na valorização do sentimento humano dos colaboradores, ante a implantação de um programa desse tipo. A organização deve 
estar consciente do fato de que é o homem quem irá colocar em prática o programa, assim como ele deve ser considerado um dos pilares das estruturas do programa, além da física e tecnológica.

O objetivo de um SC é estimular e possibilitar o registro do conhecimento explícito, assim como a geração de novo conhecimento tácito, possibilitado pelo uso das TIC. Esses recursos, quando utilizados conjuntamente, formam um SC, que permite coleta, tratamento, armazenamento e disseminação do conhecimento explícito, sendo considerado como informação, até que seja coletada, analisada, transformada e inserida em um banco ou base de conhecimento. $\mathrm{O}$ conhecimento explícito, quando internalizado pelo indivíduo, e tendo contato com suas experiências, proporcionará o aprendizado do novo conteúdo internalizado, possibilitando a transformação do conhecimento explícito em conhecimento tácito.

\section{Portais corporativos}

Com o desenvolvimento e o aumento do uso das TIC, surgiram novas possibilidades de acesso à informação. Entre essas tecnologias, o desenvolvimento de ambientes web possibilitaram que a informação seja localizada mais rapidamente, assim como a construção do conhecimento adquiriu novas formas e processos.

$\mathrm{O}$ ambiente web modificou a maneira de as pessoas realizarem as leituras, visto que os recursos disponíveis determinam novas formas de mediação da leitura, como o hipertexto. A leitura não é mais linear, ela agora é dinâmica. Pode-se ir de uma página a outra somente com um clique, os links possibilitam uma navegação dinâmica e não linear. Esse aspecto pode tornar a leitura mais prazerosa ou, ao contrário, pode ocorrer perda de informação, bem como provocar uma sensação de ansiedade informacional, no que tange a quantidade de informações disponíveis e também quanto à coerência com os pressupostos iniciais de pesquisa.

Com o seu advento, as informações são disseminadas com maior rapidez e agilidade, atingindo um grande número de usuá- 
rios. Ela promove certa democratização da informação, visto que as pessoas podem acessar e disponibilizar informação de qualquer parte do mundo (Silva, 2000, p.118), assim como dentro e fora da organização. Assim, são disponibilizados bancos e bases de dados referenciais ou com texto completo; informação formal e registrada, produzida interna ou externamente à organização; assim como ferramentas que possibilitam o registro dessas informações.

Nesse ambiente, onde novas tecnologias são desenvolvidas a todo instante, as formas de comunicação são diversas, a transmissão da informação ocorre, cada vez mais, rapidamente e em maior quantidade. Assim, o conhecimento é gerado de forma diferente do que era há alguns anos, porquanto as tecnologias da informação e comunicação, ainda, não haviam sido desenvolvidas.

As TIC podem auxiliar nesse processo, visto que podem agregar conteúdos informacionais transformando-os em conhecimento. Na sociedade contemporânea, o conhecimento tem um papel preponderante para o seu desenvolvimento. É por meio da geração e utilização do conhecimento que adquirimos base para o desenvolvimento de novas tecnologias, para a geração de inovação, nas mais diversas áreas do conhecimento, oferecendo ao próprio indivíduo oportunidades de melhoria da qualidade de vida.

A complexidade do ambiente informacional nas organizações impõe o uso de TIC que possibilitem uma dinâmica mais condizente com o momento histórico, econômico e político. Nesse contexto, surgem os portais corporativos, tendo como objetivos, entre outros, facilitar o acesso e a disseminação da informação interna e externa à organização, assim como a geração de conhecimento, por parte de seus usuários. De acordo com Terra \& Bax (2003, p.34),

Seu objetivo primário é promover eficiência e vantagens competitivas para a organização que o implementa. A ideia por traz desses portais é a de desbloquear a informação armazenada na empresa, disponibilizando-a aos utilizadores através de um único ponto de acesso [...] que lhe confere o signo de "portal", disponibiliza aplicações e 
informações personalizadas, essenciais para a tomada de decisões nos níveis estratégico (de negócio), tático e operacional.

Os portais corporativos têm por objetivo maior disponibilizar informações para auxiliar e facilitar a tomada de decisão na organização. Como define Dias (2003, p.3), "propõe-se a oferecer uma mistura de conteúdo e serviços, tais como [...] mecanismos de busca, listas de discussão, por meio de uma interface compatível com seu público-alvo...".

Nem sempre, porém, apresentam estruturas facilitadoras para o acesso e a recuperação da informação. Nesses ambientes, muitas vezes, a informação se apresenta de forma fluida e, por esse motivo, quem estrutura a estratégia de acesso e recuperação é o próprio usuário. Ressalta-se que, se a estrutura tecnológica, bem como se as ações de gestão e tratamento da informação não ocorrerem de forma adequada, o usuário, certamente, não conseguirá acessar e recuperar a informação desejada.

Pode-se considerar que os portais corporativos são instrumentos que possibilitam o acesso e a disponibilização de informação útil à organização. Objetivam prover ao usuário, geralmente os colaboradores da própria organização, informações relevantes que deem suporte ao desenvolvimento de atividades corporativas, ao processo decisório e à construção de conhecimento individual, visando à melhoria da atuação profissional, assim como no atingimento das metas estabelecidas pela organização.

O portal corporativo pode ser considerado um mecanismo de base tecnológica com poder de aglutinar em um só local toda a informação corporativa gerada, tratada e organizada, possibilitando a facilidade de acesso e localização dessa informação, assim como a geração e o compartilhamento de conhecimento, construída de forma individual e grupal. Todo esse processo possibilita à organização um maior desenvolvimento de sua competitividade ante mercado, no momento em que tem maior poder de inovação, visto que ela utiliza a produção intelectual de seus colaboradores. 
Dias (2003, p.15) defende que o portal corporativo, "em sua concepção mais completa, propõe-se a ser uma ferramenta capaz de permear todo o ciclo informacional", visto que é embutido de tecnologias e ferramentas tecnológicas capazes de organizar a informação corporativa gerada tanto no fluxo formal (estruturadas) quanto no fluxo informal (não estruturadas).

Em relação à implantação e utilização, os portais corporativos podem apresentar alguns desafios, como os apresentados por Terra \& Bax (2003):

- Presença de sistemas não integrados e formatos de arquivos proprietários e incompatíveis.

- Dificuldade de acesso ágil à informação atualizada; e, ao mesmo tempo, sobrecarga de informação.

- Redundância e duplicação de informações através das redes.

- Informações e documentos publicados de modo desorganizado, sem controle de fluxo de aprovação.

- Diversidade de caminhos, métodos e técnicas diferentes para buscar e acessar a informação.

- Dificuldade para as pessoas publicarem informações acessíveis à empresa como um todo.

- Dificuldade de definição ou ausência de políticas de segurança.

- Usuários "não técnicos" excessivamente dependentes do departamento de TI para gerar, divulgar e obter informação.

Arquiteturas proprietárias e caras dificultam a integração de diferentes tipos de informação.

Os desafios aqui citados podem servir como base norteadora para a correta implantação de um portal corporativo: necessidade de integração entre os sistemas de informação; disponibilização de informação atualizada; evitar a duplicação de informações e documentos; definição de uma política de busca e acesso à informação, assim como quanto à segurança da informação; condições reais de autonomia quanto ao uso do portal, por parte dos usuários, em relação aos técnicos em TI 
Segundo Terra \& Gordon (2002, p.97), esses portais, se bem implementados, "simplificam o acesso às informações e às aplicações [...] ajuda a poupar tempo dos empregados e disponibilizar informações exatas, relevantes e com foco e/ou fontes de conhecimento". Além disso, como se integra à intranet da empresa, "se constitui em um único ponto de acesso a todos os recursos de informação e conhecimento em uma instituição" (Dias, 2001, p.50).

A sua estrutura, em relação aos recursos tecnológicos, deve possibilitar a organização da informação corporativa relevante e útil à atuação profissional de seus colaboradores, desde a informação que já se encontra na forma estruturada, localizada em documentos (jurídicos, administrativos, pesquisa e desenvolvimento etc.), até a informação não estruturada, entre elas o conhecimento tácito do indivíduo.

\section{Considerações finais}

Um dos grandes problemas enfrentados pelas organizações atuais é gerenciamento, organização, tratamento, disponibilização e uso da informação corporativa. Os conteúdos informacionais produzidos pelas organizações têm aumentado sua quantidade e complexidade, além das informações produzidas no ambiente externo à organização, e que são disponibilizadas em maior quantidade e facilidade de acesso. Contudo, há a falta de estruturação e uso de sistemas informáticos eficientes, que auxiliem no registro e acesso a essas informações.

A Figura 1 apresenta um modelo de estrutura para sistemas de informação e conhecimento, de forma que diferentes tipos de recursos compõem esses sistemas. De acordo com a literatura analisada, esses recursos precisam manter um relacionamento entre si, para que o conhecimento registrado/explicitado em uma base se relacione com o de outra, propiciando aos colaboradores da organização diferentes possibilidades.

Dessa forma, o modelo proposto abrange ações e recursos informáticos voltados tanto para a GI quanto para a GC. Em relação à 


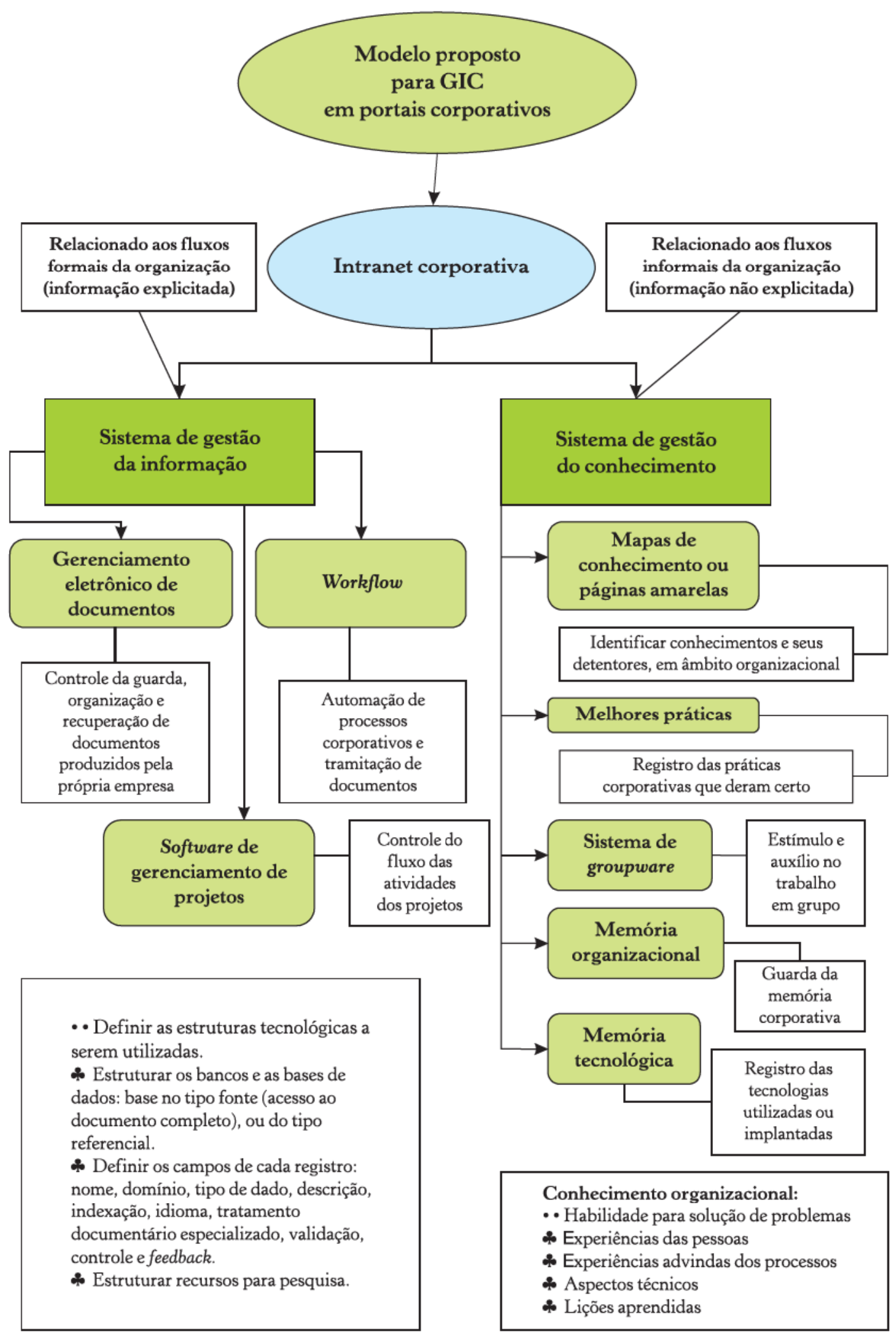

Figura 2 - Modelo proposto para GI e GC em ambiente web.

Fonte: Elaborado pela autora. 
GI, são propostos os recursos de GED, Workflow e um Software para gerenciamento de projetos. Um sistema voltado ao GED tem como objetivo maior guarda, organização e recuperação dos documentos produzidos internamente pela empresa, podendo ser de origem impressa ou eletrônica, e tem como papel fundamental fornecer à organização documentos como prova da realização de suas transações legais, comerciais, financeiras, entre outras. Os sistemas de Workflow possibilitam a automação de processos corporativos, uma vez que realiza tarefas necessárias ao processamento de documentos durante sua tramitação no âmbito organizacional, assim como a integração de pessoas e grupos na realização de atividades corporativas.

Quanto à GC, propõe-se a estruturação de bases de conhecimento como mapas de conhecimento ou páginas amarelas; bancos de melhores práticas, de memória organizacional e de memória tecnológica; e o groupware como recursos informáticos. A aplicação e a implantação de mapas de conhecimento ou páginas amarelas possibilitam à organização obter conhecimento sobre o conhecimento de seus funcionários, e proporcionam também conhecer o que a organização de fato sabe sobre ela mesma, bem como o déficit de conhecimento que ela possui. Além disso, é uma maneira de conhecer as atividades que um determinado funcionário realiza; qual é o conhecimento necessário para realizar aquelas atividades. Destaca-se também que esse tipo de recurso auxilia a elaboração de perfis de pessoal cujo uso é fundamental no momento do recrutamento e seleção de um novo funcionário ou de uma promoção interna. Outro fator importante, em relação aos mapas de conhecimento, é que eles possibilitam a disponibilização de informações que auxiliam os funcionários a identificarem quais são as pessoas que possuem determinado conhecimento, e que podem auxiliá-los na realização de determinadas atividades. Bancos de melhores práticas podem ser estruturados, para que a organização registre informações relacionadas às práticas corporativas que deram certo e que permitiram um bom desempenho à organização.

O banco de memória organizacional está voltado ao registro e guarda da memória corporativa, isto é, desde documentos até ações 
realizadas pela organização no decorrer da vida corporativa. Os bancos de memória tecnológica, por sua vez, estão relacionados às atividades voltadas ao desenvolvimento de tecnologias utilizadas ou implantadas na empresa.

Em relação aos recursos informáticos voltados à GC e propostos no modelo, definiu-se o groupware, porquanto é considerado um sistema que auxilia e estimula o trabalho em grupo, visto que a elaboração e a implantação de projetos para sistemas informáticos exigem a cooperação entre os participantes no trabalho em grupo.

Todos esses recursos descritos anteriormente precisam estar disponíveis por meio da intranet corporativa, uma vez que possibilita o inter-relacionamento entre todos os colaboradores da empresa.

A intranet proporciona algumas ações, por parte da empresa: permite estabelecer uma comunicação direta, tanto entre funcionários quanto entre a empresa e seus clientes, favorecendo processos de socialização, habilitando e estimulando os indivíduos ao compartilhamento do conhecimento tácito e explícito; permite a integração, em uma mesma solução tecnológica, de todos os recursos informáticos utilizados na implantação de um programa de GC; possibilita a inclusão de todos os recursos essenciais à captação (sistemas de prospecção e monitoramento), análise e compartilhamento do conhecimento corporativo, assim como sistemas de suporte à decisão; inclusão de um motor de busca, que possibilita a navegação, tanto no interior do site como na intranet, e a facilidade de localização, sem intermediações, de novas informações.

\section{Referências}

DAVENPORT, T. H.; PRUSAK, L. Conhecimento empresarial: como as organizações gerenciam o seu capital intelectual. Rio de Janeiro: Elsevier, 2003. 237p.

DIAS, C. A. Portal corporativo: conceitos e características. Ciência da Informação, Brasília, v.30, n.1, p.50-60, jan./abr. 2001. Disponível 
em: <http://www.scielo.br/pdf/ci/v30n1/a07v30n1.pdf $>$. Acesso em: 13 maio 2006.

Usabilidade na Web: criando portais mais acessíveis. Rio de Janeiro: Alta Books, 2003. 296p.

DRUCKER, P. F. O melhor de Peter Drucker: o homem, a administração, a sociedade. São Paulo: Nobel, 2002. 570p.

GEUS, A. de. A empresa viva: como as organizações podem aprender a prosperar e se perpetuar. 6.ed. Rio de Janeiro: Campus, 1998. 210p. JANUZZI, C. A. S.; TÁLAMO, M. de F. G. M. A empresa e os sistemas humanos de informação: uma abordagem conceitual para a gestão da informação. Transinformação, Campinas, v.16, n.2, p.171-87, maio/ago. 2004.

LAUDON, K. C.; LAUDON, J. P. Sistema de informação com internet. 4.ed. Rio de Janeiro: LTC, 1999. 389p.

LÉVY, P. As tecnologias da inteligência: o futuro do pensamento na era da informática. Rio de Janeiro: Editora 34, 1993. 208p.

MCGEE, J.; PRUSAK, L. Gerenciamento estratégico da informação: aumente a competitividade e a eficiência de sua empresa utilizando a informação como uma ferramenta estratégica. 7.ed. Rio de Janeiro: Campus, 1994.

MORESI, E. A. D. Memória organizacional e gestão do conhecimento. In: TARAPANOFF, K. (Org.) Inteligência, informação e conhecimento. Brasília: IBICT; Unesco, 2006. 453p.

NEHMY, R. M. Q.; PAIM, I. Gestão do conhecimento, "doce barbárie?” In: PAIM, I. (Org.) A gestão da informação e do conhecimento. Belo Horizonte: Editora UFMG, 2003. 306p.

OLIVEIRA, J. F. de. T.I.C.: tecnologias da informação e da comunicação. São Paulo: Érica, 2003. 444p.

PONJUÁN DANTE, G. Gestión de información: dimensiones e implementación para el éxito organizacional. Rosário: Nuevo Parhadigma, 2004.208p.

REZENDE, D. A.; ABREU, A. F. de. Tecnologia da informação aplicada a sistemas de informação empresariais: o papel estratégico da informação e dos sistemas de informação nas empresas. 4.ed. São Paulo: Atlas, 2006.327p.

ROBREDO, J. Redes de informação e de gestão do conhecimento: modelagem e estrutura de informações. In: TARAPANOFF, K. 
(Org.) Inteligência, informação e conhecimento. Brasília: IBICT; Unesco, 2006. 453p.

SANTOS, P. L. V. A. da C.; SANT’ANA, R. C. G. Transferência da informação: análise para valoração de unidade de conhecimento. DataGramaZero, Rio de Janeiro, v.3, n.2, abr. 2002. Disponível em: <http://www.dgz.org.br/abr02/Art_02.htm>. Acesso em: 19 fev. 2006.

SILVA, H. P. da. Inteligência competitiva na Internet: proposta de um processo. Florianópolis, 2000. Dissertação (Mestrado em Engenharia de Produção) - Faculdade de Engenharia, Universidade Federal de Santa Catarina. Disponível em: <http://teses.eps.ufsc.br/defesa/pdf/1750.pdf>. Acesso em: 30 set. 2004.

STOLLENWERK, M. F. L. Gestão do conhecimento, inteligência competitiva e estratégia organizacional: em busca de uma abordagem integrada. In: WORKSHOP BRASILEIRO DE INTELIGÊNCIA COMPETITIVA E GESTÃO DO CONHECIMENTO, 1., 1999. Anais... Disponível em: <http://www.abraic.org.br/ periodicos_teses/ic_a27.pdf $>$. Acesso em: 19 maio 2002.

TARAPANOFF, K. Referencial teórico: introdução. In: (Org.) Inteligência organizacional e competitiva. Brasília: Editora UnB, 2001. 343p.

TERRA, J. C. C. Gestão do conhecimento: o grande desafio empresarial: uma abordagem no aprendizado e na criatividade. São Paulo: Negócio Editora, 2000. 283p.

TERRA, J. C. C.; BAX, M. P. Portais corporativos: instrumento de gestão da informação e de conhecimento. In: PAIM, I. (Org.) A gestão da informação e do conhecimento. Belo Horizonte: Editora UFMG, 2003. 306p. Disponível em: <http://www.bax.com.br/ research/portaisCorporativosInstrumentosGestao.pdf $>$. Acesso em: 3 abr. 2007.

TERRA, J. C. C.; GORDON, C. Portais corporativos: a revolução na gestão do conhecimento. São Paulo: Negócio Editora, 2002. 453p.

VALENTIM, M. L. P. Inteligência competitiva em organizações: dado, informação e conhecimento. DataGramaZero, Rio de Janeiro, v.3, n.4, abr. 2002. Disponível em: <http://www.dgz.org.br/ago02/ Art_02.htm>. Acesso em: 25 jan. 2006. 
Gestão da informação e gestão do conhecimento: especificidades e convergências. Disponível em: <http:www.ofaj.com.br/ colunaicgc_mv_0904.html>. Acesso em: 2 dez. 2004.

O processo de construção do conhecimento. Disponível em: $<$ http://www.ofaj.com.br/colunas_conteudo.php?cod=82>. Acesso em: 19 fev. 2006. 



\title{
8 \\ A INTER-RELAÇÃO ENTRE O PROFISSIONAL DA INFORMAÇÃO E O PROFISSIONAL CONTABILISTA: NECESSIDADES INFORMACIONAIS
}

\author{
Marinês Santana Justo Smith \\ Bárbara Fadel
}

\section{Introdução}

Entre os ambientes de negócios onde as mudanças tecnológicas e econômicas são constantes estão as empresas. Essas, por não serem um corpo isolado nesse sistema, têm em suas ações forte poder de impacto em diversos agentes em seu entorno, tais como administradores, clientes, investidores, credores, colaboradores, governo e a sociedade em geral. Isso faz que esses agentes sejam usuários de sua informação contábil financeira para suprir sua necessidade informacional em determinados momentos decisórios. Nesse ambiente está o profissional contabilista, como gestor da informação contábil, que tem a responsabilidade do processo de elaboração e divulgação da informação contábil financeira aos diversos usuários, internos e externos às empresas.

Há, entretanto, críticas pertinentes à postura do profissional contabilista em razão da atenção exclusiva a determinados usuários da informação contábil. O que insere a oportunidade de o profissional da informação demonstrar a relevância de sua habilidade em diagnosticar, compreender e satisfazer as necessidades de informação ante novas expectativas dos usuários em ambiente em mutação. 
Dessa forma, a partir de uma pesquisa bibliográfica, a proposta deste estudo é discutir as contribuições do campo de conhecimento da ciência da informação no tocante a usuários e suas necessidades de informações aplicadas à área contábil financeira. Para tanto, este capítulo apresenta: discussões sobre habilidades e competências do profissional da informação no âmbito da ciência da informação; discorre sobre o papel do contabilista como gestor da informação contábil; e, por fim, apresenta reflexões da contribuição do profissional da informação ao profissional contabilista.

\section{Competências e habilidades do profissional da informação}

A gestão da informação estabelece a intersecção de pessoas, informações e tecnologia e busca determinar e maximizar atributos da informação com potencial de guiar uma ação e gerar resultados em ambientes informacionais (Ellis \& DeSouza, 2009). Diante dessa gestão, destaca-se o profissional da informação que pode exercer a sua atividade em uma diversidade de organizações e em setores público, privado e associativo que demandam a necessidade de gestão da informação.

Para Cunha (2009), os fazeres dos profissionais da informação refletem em atividades não exclusivas de uma única área profissional, com denominações variadas que representam diferentes espaços de atuação em diferentes funções e responsabilidades.

Essa ampliação, nos tipos de organizações e no leque de atividades do profissional da informação, está ligada ao progresso da ciência e do avanço das tecnologias da informação. Contudo, quais são as competências e habilidades desse profissional?

Para apontar as competências e habilidades do profissional da informação é necessário nomear os pontos de intersecção, ou convergência, entre os conceitos da ciência da informação e os procedimentos práticos constitutivos do fazer desse profissional (Smit \& Barreto, 2002). Nesse sentido, ao discutir os conceitos, objeto e ob- 
jetivos da ciência da informação, é tecida a base conceitual para a formação do profissional da informação e simultaneamente estabelece as habilidades e competências necessárias para esse campo de conhecimento à disposição do profissional da informação.

Discutir sobre objeto da ciência da informação, entretanto, não é tarefa fácil. Alguns autores como Le Coadic (1996) afirmam que seu objeto "informação" e conteúdo são bem definidos. Outros autores discordam, como Almeida Júnior (2008), que propõe a mediação da informação como objeto da ciência da informação. Smit \& Barreto (2002, p.10) destacam que

A área do conhecimento da Ciência da Informação padece de fragilidades à medida que tem dificuldade para definir seu objeto (a "informação") e convive, no estágio atual, com uma diversidade de definições acerca de seus objetivos e demarcações disciplinares [...] a ciência da informação incorporou conceitos originários de outras áreas e, ao erigir a "informação" como seu objeto (embora o faça com definições bastante diversificadas), afastou-se do documento, ampliando o campo coberto originalmente pela biblioteconomia.

Ao mesmo tempo, a evolução da tecnologia da informação ocorrida durante os últimos anos tem impactado levando à reorganização da maior parte das atividades associadas à ciência da informação, incluindo seus parâmetros teóricos, conceituais e as prioridades de seus objetivos. Mediante esse novo contexto, Smit \& Barreto (2002, p.17) articulam

o objeto de estudo da Ciência da Informação como campo que se ocupa e se preocupa com os princípios e práticas da criação, organização e distribuição da informação, bem como com o estudo dos fluxos da informação desde sua criação até sua utilização, e sua transmissão ao receptor em uma variedade de formas, por meio de uma variedade de canais. E a informação pode ser definida como: estruturas simbolicamente significantes com a competência de gerar conhecimento para o individuo e para seu meio. 
O que corrobora com o exposto nas Diretrizes (2001) citado por Valentim (2002, p.117), que ressalta a ciência da informação como campo do conhecimento que "abarca todos os fenômenos ligados à produção, organização, difusão e utilização de informações” e estabelece a informação como objeto de estudo, definindo-a como

informação registrada, acatadas as respectivas formas de vê-la, processála e utilizá-la, consoantes diferentes tradições e marcos teóricos e, como disciplinas instituidoras de ambientes de mediação entre acervos (estoques informacionais) e necessidades do usuário.

Em relação à teoria que trata do fenômeno da informação, Smit \& Barreto (2002, p.13) apontam que essa se organiza no entorno de "duas funções básicas: a) a construção dos estoques de informação; e b) a transferência ou comunicação da informação", e ainda ao redor de três fluxos básicos de informação, sendo esses:

a) um fluxo, interno ao sistema, de captação, seleção, armazenamento e recuperação da informação; b) um fluxo de passagem da informação de seus estoques para a realidade onde habitam os receptores da informação - é onde se processa a assimilação e o conhecimento a partir dessa informação; ec) um fluxo de entrada onde a criação do autor se consolida em uma inscrição de informação.

Dessa forma, a formação do profissional da informação no âmbito da ciência da informação lhe proporciona a construção de um corpus teórico que gera competências e habilidades para a resolução de problemas no entorno do ambiente informacional, e por essa formação é possível aprender como aplicar na prática esse corpus teórico.

Por competências profissionais se entende o conjunto de habilidades, destrezas, atitudes e de conhecimentos teórico-práticos necessários para cumprir uma função especializada de um modo socialmente reconhecível e aceitável. (Programa, 2000 apud Valentim, 2002, p.122) 
Essa foi a definição geral de competências, estabelecida no evento de 2000 que reuniu as escolas da área de biblioteconomia/ciência da informação do Mercosul, realizado em Montevidéu, que também descreveu várias competências específicas para o profissional da informação classificadas em quatro categorias, conforme descritas por Valentim (2002, p.122) e a seguir resumidas:

a) Competências de comunicação e expressão: abrange habilidades que contribuem para o alcance da informação pelo usuário, como a habilidade de capacitar e orientar os usuários para um melhor uso dos recursos informacionais disponíveis na unidade de informação.

b) Competências técnico-científicas: abarcam habilidades entre a busca da necessidade informacional do usuário à sua satisfação. Dessa forma, é necessário competências para entender as necessidades do usuário, selecionar, registrar, armazenar, recuperar e para difundir a informação, ou seja, promover o acesso à informação gravada para os usuários de unidades, serviços e sistemas de informação, assim como a execução de novos produtos informacionais, para a disseminação da informação.

c) Competências gerenciais: entre as habilidades de gestão classificadas como gerenciais está a de estabelecer políticas da informação, como, por exemplo, para dirigir, administrar, organizar e coordenar unidades, sistemas e serviços de informação, elaborar produtos de informação e assessorar no planejamento de recursos econômico-financeiros e humanos do setor.

d) Competências sociais e políticas: compreende habilidades que contribuem no desenvolvimento da profissão, na elaboração de política de informação com base na compreensão e participação de contextos sociais e políticos, na promoção de atitudes críticas, criativas e éticas a respeito das resoluções de problemas e questões no âmbito da informação.

Entre as quatro classificações de competência do profissional da informação descritas no evento, foi observada a preocupação com o 
usuário da informação, visto que a habilidade de planejar e executar estudos de usuários e formação de usuários da informação perpassa o domínio das quatro competências. O que corrobora e legitima a necessidade de o profissional da informação ter "sensibilidade para a necessidade informacional de usuários reais e potenciais" para o bom desenvolvimento de suas atividades de trabalho, característica citada, entre as atitudes e procedimentos profissionais necessários, na proposta de diretrizes curriculares do MEC (Valentim, 2002, p.126).

Os profissionais da informação já foram declarados como profissionais que "adquirem informação registrada em diferentes suportes, organizam, descrevem, indexam, armazenam, recuperam e distribuem essa informação em sua forma original ou como produtos elaborados a partir dela" (Le Coadic, 1996, p.106).

Esse perfil foi ampliado com as novas tecnologias de informação e mudou não só a forma de gestão da informação, como também as necessidades informacionais. No ambiente das organizações o avanço tecnológico consagrou a globalização de mercados de capitais, em que o investimento e o financiamento não têm fronteiras geográficas, portanto a exigência de informações financeiras é ampliada. Em paralelo há a questão da sustentabilidade e a responsabilidade social empresarial sendo cobrada pela sociedade, que precisa de informações sobre como a empresa está obtendo lucro, como este está sendo distribuído e como a empresa está utilizando os recursos ambientais. Esses eventos estão provocando a ampliação de usuários e das necessidades da informação, o que resulta em uma diversificação informacional, fato que insere a relevância da gestão da informação em ambientes complexos, o que incita forte atuação em estudos de usuários e necessidades informacionais.

Nesse ambiente complexo, entretanto, as ações do profissional da informação podem ser movidas pelas exigências do mercado em busca de satisfazer suas necessidades informacionais, o que pode não responder às reais necessidades informacionais da sociedade como um todo. Nesse sentido, Valentim (2002, p.130) alerta para a relevância do desenvolvimento e práticas de competências e habili- 
dades do profissional da informação que reflitam "autonomia na produção de conhecimentos, tendo como base o corpus teórico da Ciência da Informação, e que ele saiba coletivizá-los para a comunidade da área". E que reflitam também uma "ética convencionada" como destacada por Valentim (2004, p.61) para expressar o comprometimento de todas as pessoas no ambiente informacional na busca pelo respeito aos atores desse ambiente.

É necessário coletivizar a ética e o conhecimento no entorno do fluxo informacional das organizações. Oades (2008) destaca que a formação educacional do profissional da informação oferece um corpus teórico para compreensão, diagnóstico e satisfação das necessidades de informação, assim sendo, esses profissionais possuem as competências necessárias para apoiar profissionais contabilistas em seu percurso de resolução de problemas com usuários e suas necessidades de informações contábeis no entorno das organizações em ambiente globalizado. Essas informações traduzem a situação econômico-financeira das empresas, assim como sua responsabilidade social com os recursos ambientais, portanto de extrema relevância para um amplo universo de usuários.

\section{O papel do profissional contabilista como gestor da informação contábil}

Para discutir o papel do profissional contabilista, é relevante entender os conceitos do campo de conhecimento - ciência contábil que deve sustentar sua prática profissional.

A contabilidade inicialmente considerada como sinônimo de sistema e técnica de escrituração evoluiu, ainda que lentamente, para o estado de ciência, deixando transparecer que o impulso para seu surgimento e evolução é de natureza socioeconômica e que ocorre pela interação e integração de grande número de eventos econômicos, sociais e fatores históricos. E seu objetivo está relacionado com a busca de respostas práticas para os problemas emergentes no ambiente de negócios envolto pelos diversos agentes de interesse. 
Com a busca de modelos práticos para a solução de problemas gerados pelo ambiente de negócios e que atendesse às necessidades dos vários usuários, surgiu a construção de um conjunto coerente de ideias fundamentais para o desenvolvimento da contabilidade como ciência. Instaura-se a doutrina contábil, que é considerada a "face científica desse encontro fértil entre a realidade e o modelo para acolhê-la e descrevê-la. Do lento, mas maravilhoso crescimento multiforme, nasce, primeiramente, a escrituração e, mais tarde, a ciência contábil e, portanto, sua doutrina” (Iudícibus et al., 2005).

Dessa forma, a contabilidade de simples escrituração dos fatos evolui para a determinação da ocorrência dos eventos econômicos que impactam no estado de riqueza, ou seja, no patrimônio de uma entidade. E, além de determinar tal evento, a contabilidade o mensura e depois exerce também sua função comunicadora, e informa os efeitos daquele evento, assim como da nova situação patrimonial. Essa função comunicadora deve atender aos objetivos da contabilidade. Entretanto, para Iudícibus et al. (2005), os objetivos da contabilidade nascem da necessidade dos usuários da informação contábil. E que é no objeto da contabilidade - o patrimônio - que reside a resposta contábil, visto que o acompanhamento da evolução do patrimônio no tempo é o processo inicial que a contabilidade elege para iniciar o processo de geração de informações úteis para atender às necessidades dos usuários.

Em ambientes organizacionais complexos e sistêmicos, o público de interesse na saúde econômica e na forma de como a empresa faz negócios deixa de ser apenas o gestor e passa a englobar um número muito maior de pessoas e empresas de interesse. Esse grupo de usuários internos e externos é conhecido como stakeholders, que pode ser qualquer agente - grupo ou indivíduo - que afeta ou é afetado pelo alcance dos objetivos da empresa, entre eles: administradores, investidores, clientes, financiadores, colaboradores, fornecedores, governo e sociedade em geral.

Dentro desse contexto, pode-se dizer que o contabilista em seu papel de gestor da informação contábil tem como objetivo atender às necessidades dos diversos usuários da informação contábil. Para 
tanto, deve captar os fatos que imprimem variação patrimonial, elaborar e divulgar informações contábeis úteis. Contudo, deve ter observância às características que imprimem cientificidade contábil às informações. Características essas descritas por Iudícibus et al. (2005) como:

- Entendimento e mensuração pertinentes aos elementos do patrimônio da empresa.

- Preponderância do valor econômico sobre o simples custo.

- Supremacia ao registro contábil que relata o fato econômico em vez do registro único em obediência às normas jurídicas que atendem aos interesses específicos.

- Suscetíveis de avaliações contábeis.

- Caráter preditivo das demonstrações contábeis.

- Admissão do fator risco e do conceito do valor do dinheiro no tempo.

- Consideração de custos atribuídos e de oportunidade.

A Contabilidade pontifica pela observação das características anteriormente vistas e pela incorporação, em seu arcabouço conceitual, da premissa da prevalência da essência sobre a forma, no campo do conhecimento social aplicado, de natureza econômico-financeira, com ramificações nas áreas de produtividade, ambiental e social e com evidentes conotações quantitativas quanto à sua mecânica patrimonial. (ibidem, p.7)

A ciência contábil desponta, portanto, como campo de conhecimento necessário à formação de profissionais que queiram trabalhar a informação contábil como um instrumento de accountability, ou seja, de responsabilidade de prestação de contas, de avaliação da organização e de seus administradores. E, ainda, valorizar a informação contábil como recurso básico para o processo decisório dos diversos usuários de interesse na organização, tanto internos quanto externos a essa.

Em ambiente de negócios globalizados, os agentes externos e internos às empresas querem informações confiáveis e significativas 
que sejam facilmente acessíveis, e que levem à compreensão da situação econômico-financeira e de responsabilidade social da empresa. Alguns dos produtos informacionais que a contabilidade aplicada como ciência pode oferecer para responder às necessidades dos usuários nesse quesito econômico-financeiro são:

- Balanço Patrimonial (BP): apresenta informações sobre a situação patrimonial e financeira da empresa, pois demonstram os bens, direitos, obrigações e o valor do patrimônio líquido da empresa.

- Demonstração do Resultado do Exercício (DRE): apresenta informações referentes às receitas e despesas/custos, demonstrando se a empresa teve lucro ou prejuízo no período.

- Demonstrações das Mutações do Patrimônio Líquido (DMPL): demonstra como o lucro foi destinado e qual a variação do patrimônio líquido.

- Demonstração dos Fluxos de Caixa (DFC): demonstra como foi a variação dos saldos de caixa e equivalentes de caixa entre dois períodos.

- Demonstração do Valor Adicionado (DVA): demonstra o valor adicionado que a empresa gerou economicamente, ou seja, a riqueza gerada pela empresa e como ela foi distribuída entre colaboradores, governo, acionista, proprietários e reinvestido na empresa.

Esse conjunto de demonstrações contábeis consta como exigência da legislação societária, desvinculada dos limites e critérios fiscais, e tem o objetivo de atender os investidores, financiadores e demais partes interessadas que buscam informações que revelam a essência econômica das operações transacionadas pelas empresas. Essa legislação societária foi criada inicialmente para regulamentar as sociedades por ações, mas hoje sua abrangência de obrigatoriedade alcança as sociedades por ações e qualquer tipo de sociedade que seja considerada de grande porte, classificada dessa forma aquela com Ativo superior a R 240 milhões ou receita bruta anual superior a 300 milhões (Iudícibus et al., 2009). 
A elaboração desse conjunto de demonstrações contábeis com respaldo na legislação societária, mesmo pelas empresas de pequeno e médio portes, cumpriria uma das funções da contabilidade, que é comunicar a situação econômica e financeira das empresas pela essência das operações econômicas ao imprimir as características qualitativas das informações contábeis como ciência.

A prática profissional do contabilista na maioria das pequenas e médias empresas brasileiras ancora-se, contudo, numa tradição de escrituração fiscal, justificada pela ampla exigência de técnicas e normas para cumprimento e pagamento de tributos. E ainda, dependendo da opção do critério de apuração dos impostos sobre o lucro (Simples Nacional ou Lucro Presumido), ocorre a dispensa pela legislação do imposto de renda, da escrituração contábil completa e, portanto, há dispensa da elaboração das demonstrações contábeis. Um entendimento equivocado, visto que essa dispensa é apenas para efeito de cálculo do imposto de renda. O código comercial e o novo código civil não dispensam as empresas da escrituração das operações comerciais e elaboração de demonstrações contábeis. O novo código civil, aliás, faculta a regência supletiva da sociedade limitada pelas normas da sociedade anônima, mas se a empresa não optar no contrato social pela regência supletiva da legislação societária deve então seguir as normas de elaboração das demonstrações contábeis estabelecidas no novo código civil (Iudícibus et al., 2008).

No Brasil, a questão de empresas familiares efetuarem contabilidade apenas para o fisco é observada por Carvalho et al. (2006, p.11): "parece que o pensamento predominante durante décadas foi: para que investir num preparo mais acurado da posição de ativos, exigibilidades, patrimônio e lucros se a regra que prevalece é sempre a fiscal?". O que denota a força do fisco como usuário da informação contábil e a negligência para o valor informativo da informação aos demais usuários.

Essa situação, entretanto, deve mudar justamente pela força dos demais usuários. Investidores, financiadores e sociedade em geral estão exigindo prestação de contas das empresas, ou seja, buscam 
por informações contábeis com qualidade e comparabilidade nesse ambiente globalizado de mercado de capitais. E com o intuito de inserir maior qualidade, transparência e especialmente comparabilidade à informação contábil, as normas contábeis nacionais de vários países, incluindo o Brasil, estão em processo de padronização para um único conjunto de normas internacionais de contabilidade, conhecidas como IFRS - Normas Internacionais de Relatórios Contábeis.

Segundo Carvalho et al. (2006, p.11), contudo, "o caminho para a contabilidade internacional tem pedágios. Um deles é quebrarmos este perigoso e inconveniente paradigma: o de que um balanço interessa primariamente ao Fisco e é a ele que toda atenção deve ser dada".

Nesse sentido, críticas são tecidas a alguns profissionais contabilistas, justamente em relação à sua dedicação exclusiva a determinado usuário. E, como foi visto anteriormente, o objetivo da contabilidade responde às necessidades dos usuários. Dessa forma, se o contador dedicar atenção apenas ao governo como usuário das informações contábeis, e elaborá-las apenas sob suas regras e limites, essas podem não espelhar um dos principais princípios da doutrina contábil, que já foi referido neste estudo, como a "primazia da essência econômica sobre a forma jurídica”, e não vai atender às necessidades dos demais usuários. Um exemplo da ocorrência do detrimento da essência econômica é registro contábil do arrendamento mercantil, que na maioria das vezes denota uma compra financiada de bens; entretanto, não era assim reconhecido nas demonstrações contábeis, procedimento alterado recentemente pela legislação societária. Ocorre que a legislação do imposto de renda permite o registro mensal da parcela paga como despesa de arrendamento/aluguel, a consequência é que as demonstrações contábeis não refletem o registro dos bens adquiridos como aplicação de recursos nem o valor da dívida como origem de recursos e, ainda, o resultado econômico apresentado é distorcido, o que prejudica a avaliação econômico-financeira das demonstrações contábeis pelos diversos usuários da informação contábil. 
A crítica em relação à postura do profissional contabilista pela atenção exclusiva a determinados usuários da informação contábil parece, entretanto, não ter fronteiras geográficas. Oades (2008), como membro da Associação dos Contadores Certificados do Reino Unido, comenta que os contadores naquele país são frequentemente vistos como cumpridores de uma única missão, a de cortar custos e/ ou de elaborar orçamentos, ou seja, atentos apenas a um tipo de usuário, o interno, e de determinado departamento da empresa.

Com a constante evolução da tecnologia da informação, as tarefas tradicionais associadas ao processamento das transações operacionais e financeiras de rotina e apuração de obrigações fiscais têm sido, contudo, largamente automatizadas, enquanto a necessidade de fornecer informações de qualidade e específicas para apoio ao processo decisório dos diversos usuários da informação contábil tem sido ampliada. Assim, o mercado exige que o profissional contabilista desempenhe um papel diferente daquele dos últimos anos eque ainda continue evoluindo com os fatos socioeconômicos, com a constante evolução da tecnologia da informação e com a diversificação das necessidades informacionais.

A prioridade continua a ser o desempenho organizacional, mas a gama de responsabilidades ampliou. O profissional contabilista atual enfrenta desafios de negócios que são globais e estratégicos, que envolvem ética organizacional, conduta, governança, risco e oportunidades (Oades, 2008).

O cumprimento de uma série de novas exigências regulamentares de um mercado globalizado tem sido um desafio para os profissionais contabilistas. Mundialmente, o tempo gasto com atividades de relacionamento com investidores aumentou e é previsível que aumente ainda mais na próxima década. Isso visto que o ativismo de acionistas, investidores, financiadores e consumidores se torna uma prática cada vez mais comum, e portanto surge demanda por maior transparência corporativa e prestação de contas. Características consideradas como estratégicas para o enfretamento da competição global e impulso à evolução dos mercados financeiros, fato que aciona um cenário composto de um amplo universo de usuários e ávido por 
novas necessidades informacionais, uma dinâmica em que um impulsiona o outro.

Concomitantemente a essa dinâmica que a globalização de mercados de capitais está impondo, as organizações empresariais de todo o mundo, no ambiente interno das empresas de médio e pequeno portes no Brasil, ainda procedem ao desafio dos empresários e dos contabilistas em rever seus pressupostos em relação ao valor da informação contábil financeira como estratégia de negócios para o processo de tomada de decisões. Há necessidade de redefinir esses pressupostos em relação ao relevante papel da informação e suas características informativas em ambientes que demandam decisões.

Freitas (2007) destaca a influência dos valores na indicação do tipo de informação que é mais utilizada no processo decisório. Entretanto, com a gestão dos processos de informação e de conhecimento, é possível impelir-se na aprendizagem constante, o que inclui o desuso de pressupostos, normas e crenças que perderam validade para mobilizar o conhecimento e a experiência de seus membros para novas formas de gestão da informação (Valentin, 2008).

Se os empresários e contabilistas não visualizarem a informação contábil como valor estratégico, provavelmente suas empresas, ao longo do tempo, serão expelidas do mercado ou forçadas à mudança pela própria demanda informacional dos usuários. Oades (2008) observa que, no ambiente interno de algumas organizações no Reino Unido, o profissional contabilista está sendo cobrado por um volume maior de informações pelos próprios colegas de trabalho, que ampliaram a necessidade de informações diante da aversão ao risco, e que agora insistem em decisões baseadas em evidência, em oposição ao instinto executivo para tomada de decisão. Uma demonstração de que pressupostos que eram considerados válidos no passado estão sendo substituídos, o valor da informação contábil como estratégia está sendo destacado e a contabilidade exerce seu papel como linguagem de negócios e reforça que

A capacidade de capturar, primeiro, a ocorrência dos eventos econômicos que impactam em um determinado estado de riqueza, depois a 
de precificá-lo e, por último, de comunicar seus efeitos, é o desafio que a Contabilidade está, não apenas preferencialmente, mas de fato unicamente, habilitada a enfrentar, apoiando-se sempre em disciplinas afins, entre as quais o Direito, a Economia, os Métodos Quantitativos e a Ciência da Informação. (Iudícibus et al., 2005, p.8)

Aportes do campo de conhecimento da ciência da informação podem contribuir para resolver complexidades no entorno do usuário e suas necessidades de informação contábil financeira.

\section{Tecendo inter-relações entre o profissional da informação e o profissional contabilista no entorno das necessidades informacionais}

A informação contábil financeira, como já foi visto anteriormente, responde à demanda informacional no tocante à variação do patrimônio das empresas, por meio do conjunto das demonstrações contábeis que busca atingir os objetivos de comunicação da contabilidade. Contudo, para atingir esses objetivos,

é preciso um processo de comunicação claro no qual o usuário perceba com nitidez o que a linguagem contábil quer transmitir. Essa última parte do processo está longe, ainda, de ter sido resolvida eficientemente, pois envolve transmissor e receptor, ruídos de informação, capacidades distintas de absorção do significado da informação transmitida etc. (Iudícibus et al., 2005, p.12)

Dessa forma, conhecer as necessidades dos usuários é um passo fundamental na gestão da informação, considerando que os usuários retratem os seus interesses reais. A delegação desse passo ao profissional da informação permite a adoção de técnicas de análise e mediação, redução de ruídos, estudo de usuários, diagnóstico e análise das necessidades do usuário.

Para análise das necessidades do usuário e a oferta de informação, Barreto (1994, p.6) tece uma correlação entre a pirâmide das 
necessidades humanas e comportamentos, desenvolvida na década de 1970 por Maslow, e imprime que

Acredita-se que a oferta de informação, ou seja, a estrutura dos estoques, relaciona-se à demanda como uma pirâmide invertida, inversamente proporcional, em termos quantitativos e qualitativos às posições da informação demandada, configurando situações de racionamento e excedente de informações nos seus extremos.

A informação deve ser gerida como um recurso que pode ser escasso ou seletivo para satisfazer as necessidades básicas, sociais ou de autorrealização do usuário. Entende-se que o usuário se destaca como o vetor na concepção, avaliação e adaptação de qualquer sistema de informação. O que denota a necessidade de estudos de usuários.

Para Costa et al. (2009), estudos de usuário têm como objetivo conhecer se as necessidades de informações de usuários de um sistema de informação estão sendo satisfeitas de maneira adequada ou não, e ainda permite avaliar a qualidade desse processo de satisfação no tocante sua eficácia e eficiência. Os autores completam que os estudos de usuários respondem perguntas como: Por quê? Como? e Para quais fins? Quais pessoas usam a informação e também que respondem sobre quais os fatores que afetam tal uso. Corroborando Figueiredo (apud Costa et al., 2009, p.7): "Estudo de usuários são investigações que fazem para se saber o que os indivíduos precisam, em matéria de informação, ou, então, para saber se as necessidades de informação, por parte dos usuários de um centro de informação, estão sendo satisfeitas de maneira adequada".

A aplicação desse estudo de usuários ao ambiente corporativo pode prover melhorias contínuas ao sistema de informações contábeis, de forma que os produtos informacionais - como demonstrações contábeis - atendam à necessidade e expectativa dos diversos usuários, em um contexto balizado por um mercado competitivo, delineado por novas tecnologias de informação e novas demandas de informações de âmbito socioeconômico. 
Os estudos de usuário devem ser constantes, uma vez que a necessidade informacional muda, frequentemente, em razão de o ambiente corporativo estar sempre em mutação. É necessário definir quem são os reais e potenciais usuários da informação contábil; entretanto, alguns não usuários podem ser relevantes ao ambiente corporativo e requerem investimento de estudo, por isso é premente também questionar para que se destina a informação contábil e para quem essa informação pode gerar conhecimento no processo decisório.

Oades (2008, p.161) alerta que, enquanto as ferramentas de Tecnologia de Informação (TI) podem ajudar na melhora da velocidade e nos meios com que os usuários podem acessar dados da empresa, essas sozinhas não garantem a "informação mais informativa" para tomada de decisões.

O valor da informação pode ser medido pela maneira como ela possibilita aos tomadores de decisões atingirem seus objetivos e metas (Moraes \& Fadel, 2006), o que corrobora com Wersig (1993, p. 233), que afirma que "a informação é o conhecimento em ação". Dessa forma, entende-se que se a informação contábil não gerar conhecimento ou, ainda, não provocar uma ação em direção ao alcance de objetivos e metas de específico usuário em determinado processo decisório, ela não pode ser considerada uma "informação informativa” para esse usuário. Diante de uma situação como essa, a reavaliação do sistema de informação e o estudo de usuários devem ser acionados em busca de um nível maior de satisfação de necessidades informacionais.

É necessário reafirmar que a necessidade de informação se caracteriza como a busca de conhecimentos para reduzir incertezas e preencher lacunas de "informação informativa", essenciais para suporte ao processo decisório: "Isso demonstra que necessidades e usos são interdependentes, se influenciam reciprocamente de uma maneira complexa que determinará o comportamento do usuário e suas práticas" (Le Coadic, 1996, p.39).

Os gestores da informação contábil devem estar preparados para flexibilizar e viabilizar produtos informacionais que atendam às necessidades e expectativa de usuários no contexto das organizações. 
O processo pelo qual as pessoas buscam e fazem uso da informação deve ser analisado a partir do conhecimento das necessidades, das mudanças tecnológicas e dos serviços de informação. Devem continuar a se desenvolver, e o entendimento obtido de tudo isso pode se tornar cada vez mais importante para efetiva concepção de sistemas de informação e serviços informacionais (Wilson, 2008).

Choo (2006) destaca três níveis de comportamento de busca e o uso da informação que devem ser analisados:

- Situacional: nível em que a demanda do trabalho e do ambiente social em que está inserida influencia na busca e uso da informação.

- Cognitivo: nível em que a busca da informação é para suprir lacunas de conhecimento.

- Afetivo: nível em que as reações emocionais e estado psicológico interferem na busca e uso da informação.

A partir dessa análise do comportamento de busca e uso, Choo (2006) estabelece três propriedades da busca e uso da informação onde:

- Uso da informação é constituído a partir da estrutura cognitiva e emocional do indivíduo, é esse que insere significado à informação.

- Uso da informação é situacional, o meio social ou profissional define normas e práticas que impactam comportamentos por meio dos quais a informação torna-se útil.

- Uso da informação é dinâmico, o processo de busca e uso da informação interage os elementos cognitivos, emocionais e situacionais do ambiente. Processo dinâmico que altera a percepção do papel da informação e seu contexto e continuamente remodelado com os efeitos de ação e criação de significados.

No ambiente das empresas de médio e pequeno portes é percebida a predominância da característica situacional na busca e uso da informação de forma situacional, o que limita o papel informativo e dinâmico da informação contábil para alguns usuários em potencial. 
É necessário desenvolver estudos específicos sobre a busca e o uso da informação contábil financeira como meio de verificar quais as variáveis influenciadoras desse comportamento, levando-se em consideração o contexto no qual os usuários estão inseridos, bem como suas características: cultural e profissional. Com esse passo no processo de gestão da informação contábil, os contabilistas terão ao seu dispor resultados que poderão auxiliá-los a revitalizar o sistema de informação contábil, adequar seus produtos informacionais às necessidades específicas dos diversos usuários para ampará-los em algum momento que requer conhecimento em ação.

\section{Considerações finais}

Atualmente, o mercado exige que o profissional contabilista desempenhe um papel diferente daquele exercido nos últimos anos. Os desafios de negócios atuais são globais e estratégicos, e os pressupostos que eram considerados válidos no passado devem ser substituídos, ou seja, o processo de decisão não pode ser com base apenas na experiência, mas necessita também de informações com qualidade.

A permanência ou crescimento da empresa no mercado pode depender dos usuários de suas informações, que hoje, de forma ativa e diversificada, imprimem várias exigências ao comportamento empresarial. É necessário ao gestor da informação contábil elaborar informação contábil que tenha como objetivo provocar ação, cunhando-a como informação estratégica.

O exercício profissional do contabilista, nesse ambiente em constante mudança, precisa evoluir acompanhando os fatos socioeconômicos, a constante evolução da tecnologia da informação e a diversificação das necessidades informacionais para poder cumprir uma das responsabilidades que é o seu papel de comunicação da informação contábil.

Para o exercício dessa função em ambientes informacionais complexos é, entretanto, relevante ao profissional contabilista a intera- 
ção com o cientista da informação que tem como objeto de trabalho a informação, e sua formação acadêmica lhe proporciona a construção de um corpus teórico que gera competências e habilidades para a resolução de problemas em ambientes informacionais. Essas devem ser aplicadas no ambiente empresarial, pelo cientista da informação em conjunto com o profissional contabilista, para alcançar os objetivos de diagnosticar, compreender e satisfazer as necessidades de informação contábil ante às novas expectativas dos usuários em ambientes empresariais.

\section{Referências}

ALMEIDA JÚNIOR, O. F. de. Mediação da informação: ampliando o conceito de disseminação. In: VALENTIM, M. L. P. (Org.) Gestão da informação e do conhecimento no âmbito da ciência da informação. São Paulo: Polis; Cultura Acadêmica, 2008.

BARRETO, A. de A. A questão da Informação. São Paulo em Perspectiva, São Paulo, v.8, n.4, 1994. Disponível em: <http:// www.aldoibct.bighost.com.br/quest/quest2.pdf $>$. Acesso em: 6 mar. 2010.

CARVALHO, N. L. et al. Contabilidade internacional: aplicação das IFRS 2005. São Paulo: Atlas, 2006.

CHOO, C. W. A organização do conhecimento: como as organizações usam a informação para criar significado, construir conhecimento e tomar decisões. São Paulo: Senac, 2006.

COSTA, L. F. et al. (Re)visando os estudos de usuários: entre a "tradição" e o "alternativo". DataGramaZero: Revista de Ciência da Informação, Rio de Janeiro, v.10, n.4 ago. 2009.

CUNHA, M. V. Quem é o profissional da informação?: algumas reflexões. In: GARCÍA MARCO, F. J. (Ed.) Avances y perspectivas en sistemas de información y documentación: 2009. Zaragoza: Prensas Universitarias, 2009. v.326

ELLIS, P.; DESOUZA, K. C. On information management, environmental sustainability, and cradle to cradle mentalities. Business Information Review, v.26, n.4, p.257-64, 2009. 
FREITAS, M. E. Cultura organizacional: evolução e crítica. São Paulo: Thomson Learning, 2007.

IUDÍCIBUS, S. et al. Contabilidade: aspectos relevantes da epopéia de sua evolução. Contabilidade e Finanças, São Paulo, v.38, p.7, maio/ ago. 2005.

Manual de contabilidade das sociedades por ações: aplicável às demais sociedades / Fipecafi. 7 .ed. São Paulo: Atlas, 2007.

Suplemento do manual de contabilidade das sociedades por ações: aplicável às demais sociedades / Fipecafi. 7.ed. São Paulo: Atlas, 2009.

LE COADIC, Y.-F. A ciência da informação. Brasília: Briquet de Lemos, 1996.

MORAES, C. R. B; FADEL, B. Ambiência organizacional, gestão da informação e tecnologia. In: VALENTIM, M. L. P. (Org.) Informação, conhecimento e inteligência organizacional. 2.ed. Marília: Fundepe Editora, 2006.

OADES, C. Information management challenges for the professional accountant in business. Business Information Review, v.25, n.3, p.1604, 2008.

SMIT, J. W.; BARRETO, A. de A. Ciência da Informação: base conceitual para a formação do profissional. In:VALENTIM, M. L. P. (Org.) Formação do profissional da informação. São Paulo: Polis, 2002.

WERSIG, G. Information Science: the study of postmodern knowledge usage. Information Processing E Management, v.29, n.2, p.229-39, 1993.

WILSON, T. The information user: past, present and future. Journal of Information Science, v.34, p.457-64, 2008.

VALENTIM, M. L. P. Formação: competências e habilidades do profissional da informação. In: (Org.) Formação do profissional da informação. São Paulo: Polis, 2002.

. Ética profissional na área de Ciência da Informação. In: VALENTIM, M. L. P. (Org.) Atuação profissional na área de informação. São Paulo: Polis, 2004.

Informação e conhecimento em organizações complexas. In: (Org.) Gestão da informação e do conhecimento no âmbito da ciência da informação. São Paulo: Polis; Cultura Acadêmica, 2008. 



\section{9 \\ LEITURA, INFORMAÇÃO E CONHECIMENTO: NOTAS SOBRE A LEITURA DE JORNAL}

Tamara de Souza Brandão Guaraldo Oswaldo Francisco de Almeida Júnior

"Não nos faltam jornalistas, faltam leitores."

(Olavo Bilac, Correio Paulistano, 14.12.1907)

\section{Introdução}

A leitura é uma das capacidades humanas que exprimem a relação dos textos com a cultura de um período determinado, o mundo retratado pelo autor e a consciência do grupo de leitores, enunciando uma cultura vivida. Neste texto, apresentamos uma breve reflexão que desenvolvemos sobre a leitura como uma experiência concreta, que comporta práticas, saberes, leitores, sujeitos na vida cotidiana; e também dados, informações que descrevem essa experiência, escolhendo como tema dessa discussão a leitura do jornal diário.

Voltando ao passado, na Grécia antiga, o verbo ler também significava reconhecer, convencer, falar, ler em voz alta. Para pensar a leitura no passado, tanto os ouvidos quanto os olhos devem ser considerados. A capacidade de ler propagou-se em VI a.C. e no séculoV a.C., quando a leitura deixava de ser monopólio da oligarquia e passava a ser ferramenta de acesso à informação (Fischer, 2006). 
Levaria séculos para que a leitura, tida como atividade passiva, passasse a ser vista como criadora do conhecimento, o que se deu a partir do século XII, após a difusão do latim pelos escolásticos. As inovações na escrita facilitaram a leitura, tornando-a mais organizada. A imprensa, a partir do século XV, possibilitou a impressão de cópias idênticas, o que facilitou a interação entre informações diversas, pois padronizou o conhecimento ao permitir que pessoas diferentes pudessem ler os mesmos textos ou imagens (Burke, 2003, p.19).

Hoje, século XXI, muitas pessoas leem mais a palavra falada do que a escutam. É o Homo Legens (Fischer, 2006), espécie leitora, que atualmente permite que máquinas leiam seus dados entre si, sem necessidade da mediação humana. A civilização dá cada vez mais prioridade à TV, a filmes, músicas, internet, e qual será o espaço da leitura? A definição de leitura passa por mudanças, numa época em que até as máquinas leem. O que, afinal, será a leitura?

Almeida Júnior (2007) afirma que muitas são as definições sobre leitura, que abrangem desde conceitos de caráter político, social, instrumental e técnico, até mesmo poético: "a leitura nos leva a uma viagem pelo imaginário”. Independentemente de seu caráter, o autor enfatiza que a leitura é uma das preocupações da ciência da informação, e que essa faz parte do núcleo da apropriação da informação. A informação, por ser intangível, precisa de um suporte para ser veiculada e apropriada, e a decodificação desse documento pela leitura permite a apropriação da informação, possibilitando a transformação do conhecimento de quem lê. Esse processo é denominado pelo autor de mediação da informação (ibidem).

Assim, a apropriação da informação implica uma transformação do conhecimento, sendo uma ação de construção, e não de passividade. "A leitura é realizada a partir do acervo de conhecimentos de cada pessoa. Cada leitura, dessa forma, é individual, diferente de outra leitura, pois não pode prescindir dos referenciais de quem a realiza" (ibidem, p.34).

Desse modo, é importante destacar a dimensão da leitura que nos dá Paulo Freire (2006) ao relacionar a historicidade à legibilidade: 
a leitura do mundo vem antes da leitura da palavra. Assim, primeiro ocorre a decodificação do contexto e o deciframento das ideologias, sendo a compreensão do texto dependente do leitor, da história e da sociedade.

A leitura é interação produtiva entre texto e leitor, pois, desde sua constituição, o texto abriga o leitor. Sendo inacabado, o texto só se completa com a contribuição do leitor, que é levado a concluí-lo.

A leitura não encontra no texto um sentido muito limitado, daí a participação ativa do leitor na construção do sentido. Essa ideia questiona a existência de uma interpretação definitiva, porque a interação no ato da leitura é inédita, sendo o sentido o resultado do encontro entre texto e leitor (Jouve, 2002, p.102). A leitura de um texto não tem o mesmo sentido para um jovem e um adulto, o qual é impossível de se esgotar totalmente, porque, pensando na leitura do mundo, a análise não consegue dar conta de tudo o que é lido, do papel da informação na vida das pessoas: "a informação, ou perturbação, pode levar pessoas diferentes a conclusões diferentes [...] gerar possibilidades diversas em diferentes indivíduos e em diferentes situações" (Ilharco, 2003, p.36-8).

Jouve (2002, p.127) aponta duas dimensões na leitura: uma que é comum a todo leitor porque é determinada pelo texto; e outra de variável infinita porque depende do que cada um projeta de si mesmo. O leitor tira do texto não somente um sentido, mas uma significação, o que supõe uma passagem do texto para a realidade, para a vida do sujeito, que torna a leitura experiência concreta.

Fischer (2006, p.11), ao relacionar leitura, informação e conhecimento, oferece uma definição atual do que se entende por leitura: "a capacidade de extrair sentido de símbolos escritos ou impressos", sendo uma atividade de recuperação de informações da memória e que logo após constrói, baseada nessas informações, uma interpretação da mensagem.

No entendimento do autor, a vantagem humana ante outras espécies seria a nossa capacidade de buscar e organizar informações, primeiro pelo discurso articulado e, depois, pela escrita e formas e maneiras mais avançadas de leitura. A leitura é então uma resposta e 
não um estímulo, e a alfabetização não acarreta mudanças sociais e cognitivas (embora se admita que seja precondição para mudanças), mas, em sociedades complexas, consegue aprimorar a organização, auxiliando a memória e oferecendo acesso ao conhecimento (Fischer, 2006, p.39).

No Brasil, a pesquisa "Retratos da leitura", ${ }^{1}$ de caráter quantitativo, mede, desde o ano 2000, o comportamento leitor da população, especialmente com relação aos livros, e levanta junto aos entrevistados opiniões relacionadas à leitura. A pesquisa de opinião é realizada com aplicação de um questionário com 60 questões, estruturado por meio de entrevistas presenciais realizadas nos domicílios. A amostra definida representa todo o universo da população brasileira com cinco anos de idade ou mais. "Retratos da leitura" aumentou sua abrangência de $49 \%$ da população, em 2000, para $92,3 \%$, em 2007. Todo o território nacional foi coberto com 5.012 entrevistas domiciliares em todas as Unidades da Federação. Na última edição da pesquisa, o período de campo foi entre 29.11 e 14.12.2007, e apontou um crescimento da leitura no país.

A valorização da leitura, segundo dados da pesquisa, aumenta à medida que avança a escolarização dos entrevistados e em todos os suportes (livro, revista, jornal e Internet). O Ensino Superior define um índice maior de leitura: os entrevistados com esse nível de ensino leem muito mais que a média.

Para os entrevistados, a leitura está relacionada ao conhecimento, sendo esse o valor mais associado à leitura para 26\% (45,2 milhões) dos brasileiros pesquisados. Já nas opções de múltipla resposta, $42 \%$ (equivalente a 73 milhões) associam a leitura como fonte de conhecimento para a vida, 17\% (29 milhões), como fonte de conhecimento e atualização profissional, e 10\% (16,6 milhões), como fonte de conhecimento para a escola/faculdade.

1 Pesquisa coordenada pelo Observatório do Livro e da Leitura, realizada pelo Instituto Pró-livro, Organização Social Civil de Interesse Publico (Oscip), mantida por contribuições de entidades do mercado editorial (SNEL, CBL e Abrelivros) e executada pelo Ibope Inteligência. Disponível em: <http:// www.prolivro.org.br/ipl/publier4.0/texto.asp?id=48>. 
Os leitores constituíram 95,6 milhões (55\% da população estudada) e foram definidos por aqueles que leram pelo menos um livro nos três meses anteriores à pesquisa. Já os não leitores totalizaram 77,1 milhões (45\% da população estudada) que não leram nenhum livro nos três meses anteriores à pesquisa ou leram/folhearam outros suportes que não livros. Entre as principais dificuldades apontadas pelos brasileiros na pesquisa para a não leitura, podemos citar três limitações relevantes que relacionam a leitura ao conhecimento: a falta de fluência na leitura (ler devagar) para 16\% do universo $(28,1$ milhões); a não compreensão, citada por 7\% (11,9 milhões); e não ser alfabetizado, por 15\% (25,4 milhões).

Muitos estudiosos, como Jouve(2002), Santaella (2004) e Fischer (2006), enfatizam a dimensão cognitiva da leitura, porque após o deciframento dos signos o leitor tenta entender do que se trata, fazendo um esforço de abstração, procurando interpretar o texto, o que exige um saber mínimo para que a leitura prossiga:

O deciframento do leitor é mais fácil quando o texto comporta palavras breves, antigas, simples e polissêmicas. Por outro lado, como a capacidade de memória imediata de um leitor (o "espaço de memória") oscila entre oito e dezesseis palavras, as frases mais adaptadas aos quadros mentais do leitor são as curtas e estruturadas. (Jouve, 2002, p.18)

Exatamente como o texto do jornal. O jornal é um suporte de informação que permanece resiliente no século XXI, pois tem como uma de suas características a universalidade, sendo feito para todo leitor que se encontra em sua abrangência geográfica e seja capaz de lê-lo. A leitura de jornal, contemporânea do leitor, permite renovar a sua percepção dos fatos. Desse modo, o papel do jornal é informar e situar o leitor na vida cotidiana, social e política, ampliando seu conhecimento. 


\section{Leitura de jornal}

No decorrer dos séculos XVI e XVII, a leitura era rápida, ainda oficial e educacional, com a impressão de cartazes, panfletos, documentos, jornais locais, textos administrativos e judiciais, cartilhas, catecismos, textos para aulas e livros cerimoniais para uso paroquial (Fischer, 2006, p.224). A imprensa de periódicos europeia originou-se no século $\mathrm{XV}$, com envio de relatórios para banqueiros, comerciantes, políticos, referentes a questões financeiras e políticas: batalhas, invasões, casamentos e posses. Panfletos divulgavam acontecimentos marcantes como cometas, catástrofes, histórias fascinantes.

No século XVI, panfletos e relatórios eram impressos em maior quantidade para circulação pública. Havia um panfleto de uma folha só contendo resumos gerais dos acontecimentos da província, nação e continente europeu. A maioria dessas notícias era passageira e voltada para as massas, e Fischer (2006, p.225) supõe que atingiam quase todos os membros da comunidade. Próximos ao final do século XVI, periódicos regulares e assinados começam a aparecer. Alguns desses impressos eram feitos por intelectuais, religiosos, comprometidos com movimentos como o Iluminismo e a Reforma. Outros eram comerciais e serviam a qualquer tipo de público.

Os panfletos, comuns no século XVI, e jornais e revistas publicados após 1600, eram os gêneros que ilustravam a "comercialização da informação”, pois as notícias já eram vistas como mercadorias no século XVII. Nesse século a leitura em latim desaparecia, com exceção de textos religiosos e acadêmicos, e os primeiros jornais do mundo começavam a ser lidos. Também eram comuns os boletins manuscritos, que continham as notícias impróprias para impressão, em razão da censura (Burke, 2003, p.152).

As publicações periódicas se tornaram mais numerosas após o século XVII: almanaques, gazetas, notícias, anúncios públicos, propaganda. Mas a censura abafava o leitor, impedindo o desenvolvimento da imprensa como motor social. No século XVIII a maior parte da população europeia ainda tinha muita dificuldade na leitu- 
ra. Esse foi o século do livro com a grande popularidade do romance nas vendas (Fischer, 2006, p.239).

A leitura de jornal só passa a ser hábito cotidiano no século XIX em países como a França e os Estados Unidos. Como a média salarial da população francesa era baixa, a principal fonte de leitura era o periódico barato, enquanto nos Estados Unidos, à época da Guerra Civil (1861 -1865), uma rede complexa de impressão tornou o livro e o jornal "objetos comuns da vida cotidiana" (ibidem, p.259).

Os séculos XVIII a XX são considerados a Era de Ouro do jornal, pois esse se tornou o suporte mais lido em qualquer nação. Jornais europeus eram grandes empreendimentos que empregavam muitas pessoas. Contudo, o autor aponta que esses jornais não"eram feitos para leitura rápida”, pois os leitores do século XVIII e XIX tinham tempo de se dedicar a esses materiais, assim não havia manchetes em negrito para chamar a atenção do leitor e os artigos ocupavam grande espaço. $\mathrm{O}$ jornalista recorria à razão, e em resposta o leitor "refletia com ponderação, sem pressa, sobre o que lia" (ibidem, p.262).

Na década de 1830, em Nova York, a redução do preço da cópia para um centavo e a especialização em sensacionalismo levou a um crescimento extraordinário dos jornais em tiragem, sendo esse o principal veículo de informação mundial até a eclosão da Primeira Guerra (1914-1918). O jornal era a principal fonte de diversão dentro de casa, antes do rádio e da TV tomarem o seu lugar (ibidem, p.270).

Após o aparecimento de outros meios de informação, o jornal eo público leitor passaram por mudanças: muitas páginas passaram a ser folheadas e não lidas. As manchetes passaram a ser resumos, e o texto, exposição sucinta. $\mathrm{Na}$ ânsia de virar a página, houve a preferência por relatos rápidos, pois, para leitura mais aprofundada, o leitor poderia recorrer às revistas.

O prazer diário da leitura do jornal havia sido perdido [...] O diário [...] tornava-se um resumo apressado dos fatos. E com o tempo se tornou uma característica desse tipo de veículo. Claro que os editores de jornais tinham duas opções: atender às expectativas ou falir. Em conse- 
quência dessa mudança, quase todos os jornais diários no início do século XXI publicam textos menores, assim como manchetes e fotografias coloridas maiores. (ibidem, p.270)

No Brasil, a implantação da imprensa data de apenas 200 anos (século XIX), recente em comparação com os países europeus (século XV), e as Américas Espanhola (século XVI) e Inglesa (século XVII). O atraso na implantação da imprensa no país deveu-se a fatores políticos, econômicos e socioculturais, além da ausência de condições infraestruturais. Melo (1973), em estudo clássico, apontou que o retardamento com que a imprensa chegou ao Brasil não seria somente por questões políticas e econômicas de Portugal com sua colônia, já que em outras possessões portuguesas, como as asiáticas, a imprensa foi logo introduzida. É que a imprensa é produto de fatores como a urbanização, desenvolvimento do comércio e indústria, alfabetização, elevação do nível cultural das elites pela existência de universidades, elementos esses ausentes no Brasil até início do século XIX.

Ainda hoje, os jornais diários no Brasil se concentram, em sua maioria, nas proximidades das cidades, em locais de desenvolvimento acentuado, o que atrela esses meios às relações de produção, e ao Estado, na implantação de redes escolares promotoras do hábito da leitura.

O Brasil, junto a outros países que também apresentaram grande crescimento econômico na primeira década do século XXI, como a Rússia, a Índia e a China, os Brics, em relação aos jornais diários por grupo de mil habitantes, nosso país aparece como o último da classe, com pouco mais de 50 cópias por mil habitantes, o que equivale a cerca de um terço dos da Rússia, e metade dos da China e da Índia (Goyos Jr., 2010).

Os jornais brasileiros, nos últimos anos, mantêm uma circulação estável ou um aumento correspondente ao crescimento demográfico. Com o lançamento de jornais populares, a população de baixa renda passou a integrar o público leitor, e esses jornais avançaram diversas posições entre os dez diários de maior circulação no país, o 
que se refletiu num aumento da circulação total de jornais no Brasil (Associação..., 2008).

Tabela 1 - Circulação média diária dos jornais pagos no Brasil

\begin{tabular}{llll}
\hline Ano & $\begin{array}{l}\text { Circulação nacional* } \\
\text { Milhões de exemplares/dia }\end{array}$ & Variação \% & $\begin{array}{l}\text { Afiliados ao IVC } \\
\text { Milhões de exemplares/dia }\end{array}$ \\
\hline $\mathbf{2 0 0 8}$ & 8.487 & 5,0 & 4.351 \\
$\mathbf{2 0 0 7}$ & 8.083 & 11,8 & 4.144 \\
$\mathbf{2 0 0 6}$ & 7.230 & 6,5 & 3.706 \\
$\mathbf{2 0 0 5}$ & 6.789 & 4,1 & 3.480 \\
\hline
\end{tabular}

Fonte: Associação Nacional de Jornais (2008).

A circulação média dos jornais diários não chega hoje a dez milhões de exemplares de jornais no país, o que nos leva a deduzir que o hábito da leitura de jornal não está plenamente disseminado entre os leitores brasileiros e tem grande potencial para crescer. Segundo a pesquisa "Retratos da leitura", 48\% dos brasileiros, ou 83,3 milhões, são leitores de jornal. O jornal é o suporte com maior frequência de leitura no país, ficando a frente dos livros, revistas e textos da Internet, com 20\% de leitura diária. Entre os leitores de jornal, 57\% (54,7 milhões) afirmam dedicar em média 1h21 min semanais à leitura de jornal.

Tabela 2 - Tempo de leitura de jornal (minutos por dia)

\begin{tabular}{lll}
\hline Ano & Segunda a sábado & Domingo \\
\hline $\mathbf{2 0 0 7}$ & 45,38 & 49,53 \\
$\mathbf{2 0 0 6}$ & 45,70 & 51,53 \\
$\mathbf{2 0 0 5}$ & 46 & 51 \\
$\mathbf{2 0 0 4}$ & 47 & 54 \\
$\mathbf{2 0 0 3}$ & 50 & 54 \\
$\mathbf{2 0 0 2}$ & 51 & 56 \\
$\mathbf{2 0 0 1}$ & 64 & - \\
\hline
\end{tabular}

Fonte: Ibope Monitor (Associação..., 2009). 
Assim, a imprensa continua a ser uma indústria em crescimento, tanto no Brasil como no mundo. Segundo dados da World Association of Newspaper (WAN) - Associação Mundial de Jornais, divulgados em 2009, ${ }^{2}$ as vendas mundiais de periódico aumentaram $9 \%$ nos últimos cinco anos. Em todo o mundo, 1,9 bilhão de pessoas leem jornais diariamente, o que corresponde a $34 \%$ da população. Em comparação, o estudo aponta que $24 \%$ da população mundial acessa a Internet. O maior mercado mundial de jornais é a Índia, com circulação média diária de 107 milhões de exemplares, seguida da China e do Japão, que juntos respondem por $60 \%$ da circulação de periódicos no mundo. O Japão lidera a leitura mundial de jornais com 612 cópias por mil habitantes.

No ano anterior, em 2008, a pesquisa "Tendências mundiais da imprensa" 3 destacou que, somados os jornais gratuitos, a difusão total aumentou 14,3\% entre 2003 e 2007. O Brasil ganhou destaque registrando aumento de $24,93 \%$ de circulação nesse período. Enquanto a leitura de jornal cresce na América do Sul e na Ásia, declina nos Estados Unidos e na Europa, onde se observa, porém, aumento de circulação de jornais gratuitos.

No século XXI as previsões sobre o futuro do jornal impresso diante do avassalador crescimento das novas tecnologias culminam com o pensamento sobre o fim da era do papel e a afirmação da Internet como novo veículo que produzirá a interação total leitorjornal. Seria o fim do jornal, tal como o conhecemos hoje? O jornal irá migrar totalmente para a Internet, em suas versões on-line? Quais as consequências dessa mudança?

Dines (2009, p.23) relembra o impacto da chegada da TV em cores na década de 1970 e das transmissões por satélite, que levaram

2 A pesquisa anual realizada pela WAN sobre as Tendências da Imprensa Mundial foi apresentada dia $1^{\circ}$ de dezembro de 2009 no Congresso Anual da Associação, que ocorreu em Hyderabad, na Índia, no qual a questão do conteúdo pago foi debatida. Disponível em: <http://www.wan-press.org/ article18330.html>

3 "World Press Trends: Newspapers Are A Growth Business". Disponível em: $<$ http://www.wan-press.org/article17377.html>. 
muitos a acreditar na destituição do jornal impresso de sua função referencial. O que ocorreu, porém, foi uma coexistência de tecnologias, com diferentes formatos que se completavam. Hoje, época de obsolescência imediata, é anunciado o fim dos mais de quatrocentos anos do jornal impresso, que antes funcionava como referência, e, ao alardear a proximidade de sua morte, "apresenta-se diante da sociedade moderna como uma entidade obsoleta, frágil. Portanto, inconfiável" (ibidem).

Essa fragilidade ocorreu em razão das crises anunciadas por mais de duas décadas e porque os jornais deixaram-se suplantar pela Internet, só reagindo quando "os produtores de conteúdo da Internet noticiaram o fim da gratuidade e do acesso universal, deu-se o milagre: a mídia impressa de repente anunciou sua cura" (ibidem, p.24).

Fischer (2006, p.270) relembra que é a leitura que acompanha as novas tecnologias: o cinema tem legendas, no computador a atividade é toda baseada na leitura, pois "requer um envolvimento ativo, direto e integral com a palavra escrita", ressaltando que isso permanece até que os sistemas de reconhecimento de voz estejam plenamente em uso. No computador a palavra escrita chega a substituir a falada: correio eletrônico, salas de bate-papo, Internet. No entanto, a principal fonte de leitura do mundo continua a ser o jornal diário, que ganha por pouco da tela do computador no mundo desenvolvido (ibidem, p.275).

A Internet como ferramenta é imbatível, mas dificilmente conseguirá oferecer ao leitor uma plataforma noticiosa organizada e um conjunto de narrativas como o oferecido pelos impressos. O fluxo - na verdade ojorro - da Interneté intenso e contínuo, esta sua grande vantagem. E também sua intrínseca desvantagem: impossível manter o mesmo padrão de contextualização de tantas informações ao longo de uma jornada. E sem contextualização, desorganizado e fragmentado, o conhecimento pouco vale. (Dines, 2009, p.23)

De percepção instável, móvel, o leitor contemporâneo é um leitor fugaz, de linguagens híbridas, leitor de manchetes, fragmentos 
de texto. Os desafios do jornal impresso são também referentes a uma nova geração de leitores nascidos com os estímulos do videogame, computador e Internet, além de outro tipo de leitor, mais tradicional e que busca uma análise mais detalhada oferecida pelas revistas semanais. Contudo, os jornais são mais estruturados para coletar e tratar a informação, até mesmo pautando outros meios, pois respondem por metade do conteúdo novo produzido, em comparação com as novas mídias, que são responsáveis pela produção de apenas $4 \%$ do conteúdo que veiculam. As matérias de jornal são reproduzidas sem licença em média 4,4 vezes na Internet (Brito, 2010).

Bentley (2000, p.19) afirma que no âmbito da indústria de jornais a explicação dominante para a tenacidade desse meio é a paixão pelo conteúdo sustentada pelos seus leitores. Assim, o sentido da leitura interage com o contexto cultural do leitor e com uma época, afirmando uma dimensão simbólica.

\section{O leitor de jornal}

Jouve (2002, p.36) argumenta que, pelo tema que aborda e pela linguagem que usa, "cada texto desenha no vazio um leitor específico", sendo as máscaras do leitor a do indivíduo concreto, a do membro de um público reconhecido e a de uma figura virtual construída pelo texto.

Quando o sujeito conhece e reconhece o ambiente a seu redor, torna-se ativo em relação a esse, e passa a atuar como ser transformador. A leitura de jornal pode ser um meio para a percepção do meio em que vivemos, informação que nos torna críticos e construtores de nosso próprio conhecimento. O leitor pode ser apreendido por intermédio do público de que toma parte. É uma figura histórica, individual ou coletiva, sendo inicialmente uma figura virtual do texto: é o receptor/destinatário do discurso que a ele se dirige.

Ao colocar em evidência o mundo do texto e o mundo fora do texto, consideramos que há um leitor inscrito no texto, mas, por sua vez, existe um indivíduo que segura o jornal nas mãos. Como defi- 
nir essa relação? Para Jouve (2002, p.37), a resposta é simples: é preciso considerar o primeiro como um papel proposto para o segundo. Esse papel é possível de ser recusado com a interrupção da leitura, pois o leitor não tem a obrigação de se reconhecer no destinatário-padrão (ibidem, p.38).

Esse leitor é plural, contextualizado, com suas experiências, cultura, valores. A interpretação do leitor é independente da visão do autor sobre seu texto (ibidem). Diferentes leituras de um mesmo texto são possíveis, pois o mesmo leitor lê de modo diverso em diferentes épocas de sua vida (Chartier, 2002). O textoé preenchido pelo ato de leitura, sendo a soma de práticas, conhecimentos e horizontes do leitor. Os leitores são grupo social heterogêneo.

Pesquisas sobre o leitor ou usuário do jornal são realizadas desde as primeiras décadas do século XX nos Estados Unidos, tanto em universidades quanto em institutos de pesquisa, e apontam que os leitores frequentes, como os assinantes, são geralmente chefes de família de bom nível educacional, com idade entre 35 e 64 anos. Já o não leitor foi caracterizado pelas pesquisas quantitativas como parte dos extremos: muito jovem ou muito velho, de baixa escolaridade, renda e ocupação, morador da zona rural. Os motivos citados para a não leitura de jornal nos Estados Unidos foram a falta de tempo, o uso de outros meios, o custo e a falta de interesse nos conteúdos (Bentley, 2000).

Quanto aos estudos sobre o leitor de jornal e a leitura de jornal no Brasil, no âmbito acadêmico, poucos trataram do leitor de jornal em particular, visto como um anônimo dentro de um vasto público. Existe uma escassez de investigações que têm por objetivo o leitor de jornal, "apontando para a necessidade de novas pesquisas nessa direção, dessa vez junto aos jornais” (Adghirni \& Baesse, 2009, p.12).

Em contrapartida, as empresas jornalísticas procuram empresas especializadas em pesquisa de mercado de opinião quando se encontram diante de problemas a serem resolvidos com urgência, como a busca de dados que fortaleçam o jornal ante outros canais como opção para o investimento em publicidade dos anunciantes. 
Nas pesquisas de mercado, os leitores são classificados de acordo com a quantidade de leitura de jornal efetuada na semana, sendo considerados, geralmente, três níveis de leitores: Light readers, os que leem apenas uma edição de jornal na semana; Medium readers, os que leem de duas a três edições; Heavy readers, leitores que leem de quatro a cinco edições semanais.

A pesquisa "Quero Comprar 2 $2^{\text {a }}$ Onda" ${ }^{4}$ foi realizada em 2006 pelo Instituto Ipsos/Marplan Media Research a pedido da Associação Nacional de Jornais (ANJ), e concluiu que o leitor de jornal é mais ávido por informação que o não leitor, sendo também mais informado e culto, com seu tempo livre mais bem aproveitado, um consumidor mais consciente e moderno. A pesquisa, quantitativa de opinião, buscou fortalecer o jornal como canal de informação para compra de produtos, com o objetivo de entender como se dava o processo de decisão de compra entre os leitores de jornais e em que medida esse exercia influência no processo de compra. Foi realizada em 2006, em doze cidades (Belo Horizonte, Brasília, Campinas, Curitiba, Florianópolis, Fortaleza, Porto Alegre, Recife, Rio de Janeiro, Salvador, Santos e São Paulo), com público-alvo formado por homens e mulheres de 18 a 69 anos, das classes ABCD, leitores e não leitores de jornais. O critério para definição de leitor era ter lido ou folheado o jornal nos últimos três meses. Os leitores de jornal na Internet não entraram no filtro de leitor. Para investigar a influência da informação no processo de decisão, foram realizadas 1.760 entrevistas, sendo 1.224 entrevistados definidos como leitores e 536 como não leitores. A pesquisa foi realizada com entrevistas domiciliares utilizando a técnica face a face. Na pesquisa da ANJ, 69\% dos entrevistados declararam ter lido jornal nos últimos seis meses.

4 Disponível em: <http://www.anj.org.br/sala-de-imprensa/pesquisas/querocomprar-2>. 


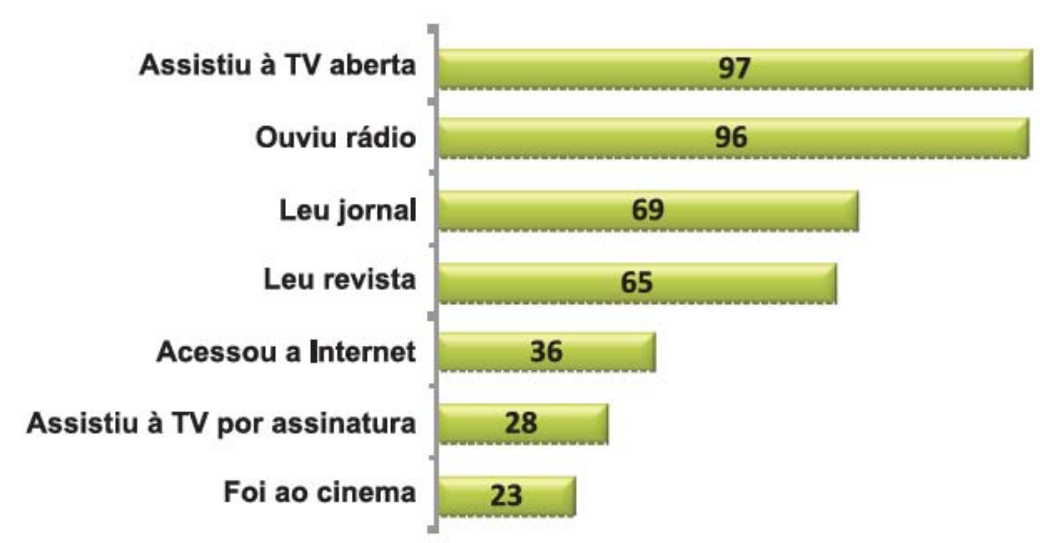

Gráfico 1 - Consumo de mídia 1.

Fonte: Ipsos/Marplan/ANJ (2006).

Quem lê jornal, segundo a pesquisa, se caracteriza como um ávido consumidor de informação e consome, lê e acessa mais todos os outros meios, como demonstram os dados da Tabela 3 :

Tabela 3 - Consumo de mídia 2

\begin{tabular}{l|l|l|c}
\hline & Leitor & Não leitor & $\begin{array}{l}\text { Índice 100 } \\
\text { (leitor em relação a não leitor) }\end{array}$ \\
\hline Assistiu à TV por assinatura & $33 \%$ & $17 \%$ & 194 \\
\hline Foi ao cinema & $27 \%$ & $14 \%$ & 193 \\
\hline Acessou a Internet & $41 \%$ & $26 \%$ & 158 \\
\hline Leu revista & $72 \%$ & $49 \%$ & 147 \\
\hline Assistiu à TV aberta & $98 \%$ & $95 \%$ & 103 \\
\hline Ouviu rádio & $97 \%$ & $95 \%$ & 102 \\
\hline
\end{tabular}

Fonte: Ipsos/Marplan/ANJ (2006).

A maior frequência de leitura de jornais se dá às quartas-feiras (55\%) e aos domingos (66\%) entre aqueles que leram jornal na semana anterior à pesquisa. E a maior parte dos leitores lê um quarto do jornal durante a semana, lendo mais e por mais tempo aos domingos. Assim, o tempo médio de leitura é maior aos domingos quando os entrevistados afirmam gastar por volta de meia hora com a leitura do exemplar. Esse índice caiu de 33 minutos na pesquisa de 2000 (Quero Comprar 1) para 31 minutos na de 2006. Domingo é tam- 
bém o dia em que se lê a maior quantidade do jornal, pois 19\% dos leitores afirmam ler quase a metade das páginas nesse dia. Em geral, $60 \%$ do público leitor lê jornal antes do almoço.

A TV (54\%) e o jornal (36\%) são os meios mais utilizados, pelos leitores, para se informar sobre as notícias da cidade e a política do Brasil. O jornal ocupa o segundo lugar na percepção de atributos como: mídia mais confiável (32\%), mais útil (31\%) e de maior proximidade com os assuntos da cidade (29\%), perdendo apenas para a televisão. Já os não leitores se informam mais pela TV e rádio. A TV é a campeã, tanto entre leitores como não leitores, como mídia mais confiável para se obter informação, com 30\% da preferência geral. Entre os leitores, TV e jornal praticamente dividem a preferência em relação à confiabilidade da informação, conforme dados do Gráfico 2.

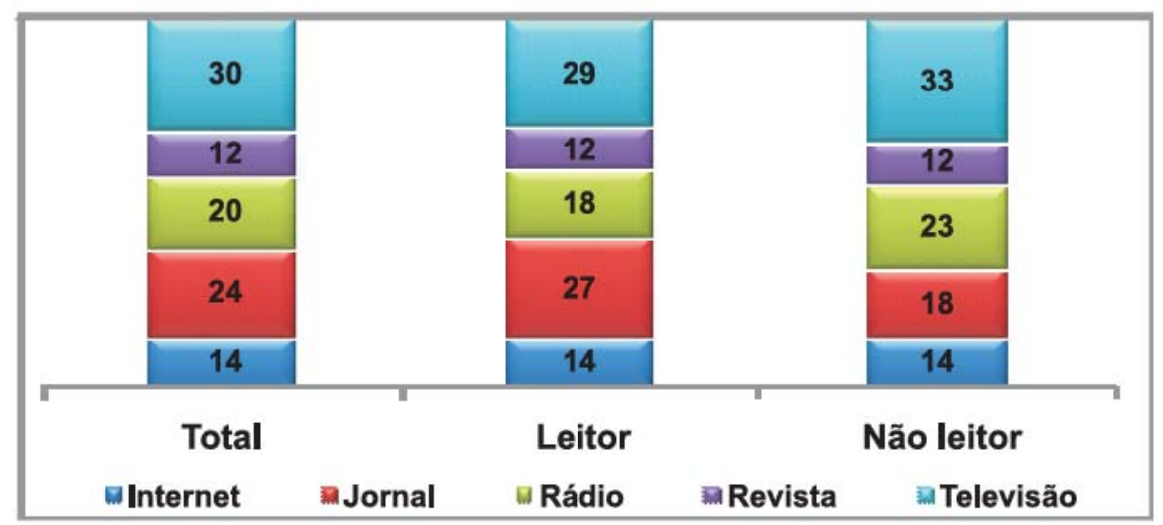

Gráfico 2 - Mídia mais confiável para busca de informação.

Fonte: Ipsos/Marplan/ANJ (2006).

Essa pesquisa levantou um perfil do leitor de jornal destacando que os homens são os que mais leem e com maior percentual de Heavy readers. A maioria dos adultos (25 a 54 anos) tem o mesmo padrão de leitura (+/- 40\% entre Heavy e Medium). A diferença maior se dá nos jovens (18 a 24 anos), dos quais 67\% são Medium e Light; versus os mais adultos ( 55 a 69 anos), dos quais 48\% são Heavy e Medium. Os dados demonstram que um dos maiores desafios atuais do meio é atrair o jovem, que lê cada vez menos jornais ou lê de forma esporádica. 
Outra pesquisa recente "O poder do meiojornal", ${ }^{5}$ também realizada pelo Ipsos/Marplan, a pedido da ANJ em 2008, foi de caráter qualitativo com o uso das técnicas de discussão em grupo e da entrevista em profundidade abrangendo oito grupos de leitores de jornal, homens e mulheres jovens (18 a 24 anos) e adultos (25 a 50 anos). Além disso, foram realizadas treze entrevistas com formadores de opinião, tomadores de decisão e executivos de primeiro escalão. A pesquisa teve como enfoque explorar o envolvimento do leitor com o jornal, tendo por objetivo encontrar as principais características do meio para fortalecer a defesa estratégica do jornal para fins publicitários. Algumas questões discutidas foram: o que significa informação para o leitor, quais as principais fontes de informação que utiliza, o jornal como fonte de informação, a relação do leitor com o jornal e as principais características desse meio, entre outros itens.

O leitor de jornal foi identificado pela pesquisa como sendo formado por homens e mulheres, classe $\mathrm{AB}$, desde jovens em idade universitária a adultos independentes, com vida familiar e profissional consolidada.

Foi identificado nos grupos de discussão o jornal como o meio que oferece a informação mais detalhada, em profundidade e abrangência. Nos grupos, verificou-se que o jornal é lido geralmente no período da manhã. A materialidade do suporte também foi citada pelos entrevistados como experiência sensorial de guardar, dobrar, levar o jornal consigo:

Os textos não existem fora dos suportes materiais (sejam eles quais forem) de que são os veículos. Contra a abstração dos textos, é preciso lembrar que as formas que permitem sua leitura, sua audição ou sua visão participam profundamente da construção de seus significados. (Chartier, 2002, p.62)

5 Pesquisa apresentada no $7^{\circ}$ Congresso Brasileiro de Jornais sobre a importância do Meio Jornal. Disponível em: <http://www.anj.org.br/sala-de-impren$\mathrm{sa}$ /pesquisas/o-poder-do-meio-jornal $>$. 
Jornais são lidos pela tradicionalidade, por hábito, pelo valor e pela qualidade da informação produzida, pela credibilidade e segurança na leitura das informações veiculadas. A pesquisa mostrou que a confiança que o leitor tem ao receber uma notícia por meio do jornal é estendida aos anúncios publicados no mesmo espaço. O valor social do jornal foi identificado pelos leitores como uma possibilidade de congelar o tempo, o retrato de um dia histórico, além de ser visto como um registro da sociedade, um verdadeiro livro do cotidiano.

Em que pese o rigor metodológico, a amostragem representativa e a abundância de dados relevantes em relação à leitura de jornal, as pesquisas de mercado apresentam uma visão fortemente utilitária da leitura e do leitor. Ao destacar o quanto é lido de cada edição, o tempo médio de leitura, o tipo de informação procurada, e o uso que se faz disso, a classificação do leitor por critérios quantitativos de leitura, os light, medium e heavy readers, essas pesquisas realçam, em sua maioria, apenas a dimensão comercial do público. De caráter imediatista, pois buscam resolver problemas de mercado das empresas jornalísticas como a eterna busca por anunciantes, essas pesquisas enfatizam muito mais o uso do que a apropriação da informação, não se interessando pela aquisição de conhecimento por parte do leitor, o que hoje é parte do papel do jornal na sociedade.

$\mathrm{O}$ que torna o leitor regular diferente dos outros? $\mathrm{O}$ fato de que ele é criador, produtor e não apenas um receptor vulnerável ante o texto, o leitor é um sujeito histórico capaz de verbalizar e explicar suas ações. E complementando, não seria o leitor regular um privilegiado? Alguém que por ler mais desfrutaria de um maior prestígio na sociedade, já que uma das finalidades da leitura é o conhecimento?

\section{Referências}

ADGHIRNI, Z. A.; BAESSE, J. M. S. Gêneros opinativos e Internet: mais espaço para o leitor. In: CONGRESSO BRASILEIRO DE CIÊNCIASDA COMUNICAÇÃO, 32, 2009, Curitiba, Anais eletrônicos... São Paulo: Intercom, 2009. (CD-ROM). 
ALMEIDA JÚNIOR, O. F. Leitura, mediação e apropriação da informação. In: SANTOS, J. P. (Org.) A leitura como prática pedagógica na formação do profissional da informação. Rio de Janeiro: Biblioteca Nacional, 2007 p. p.33-45.

ASSOCIAÇÃO NACIONAL DE JORNAIS (ANJ). Comentários sobre o meio jornal. 2008. Disponível em: <http://www.anj.org.br/ a-industria-jornalistica/comentarios-sobre-o-meio-jornal>. Acesso em: 12 jan. 2009.

BENTLEY, C. H. Make my day: ritual, dependency and the habit of newspaper reading. Oregon, UO, 2000. 254f. Tese (Doutorado) School of Journalism and Communication and the Graduate School of the University of Oregon, Doctor of Philosophy. Disponível em: $<$ http://web.missouri.edu/ bentleycl/bentleydissertation.pdf $>$. Acesso em: 20 jan. 2010.

BRITO, J. O valor do jornalismo. Bom Dia, Bauru, p.7, 26 fev. 2010. Disponível em: <http://www2.redebomdia.com.br/flip/bauru/ 2010/2/26/index.html>. Acesso em: 28 fev. 2010.

BURKE, P. Uma história social do conhecimento: de Gutenberg a Diderot. Rio de Janeiro: Zahar, 2003.

CHARTIER, R. Os desafios da escrita. São Paulo: Editora Unesp, 2002.

DINES, A. O papel do jornal e a profissão de jornalista. 9.ed. São Paulo: Summus, 2009.

FISCHER, S. R. História da leitura. São Paulo: Editora Unesp, 2006.

FREIRE, P. A importância do ato de ler: em três artigos que se completam. 48.ed. São Paulo: Cortez, 2006.

GOYOS JUNIOR, D. N. Os Brics e os jornais diários. Bom Dia, Bauru, p.7, 28 fev. 2010. Disponível em: <http://www2. redebomdia.com.br/flip/bauru/2010/2/28/index.html>. Acesso em: 28 fev. 2010.

ILHARCO, F. Filosofia da informação: uma introdução como fundação da acção, da comunicação e da decisão. Lisboa: Universidade Católica, 2003.

JOUVE, V. A leitura. São Paulo: Editora Unesp, 2002.

MELO, J. M. Sociologia da imprensa brasileira: a implantação. Petrópolis: Vozes, 1973.

SANTAELLA, L. Navegar no ciberespaço: o perfil do leitor imersivo. São Paulo: Paulus, 2004. 



\section{0 \\ CULTURA ORgANIZACIONAL E AS INTERFERÊNCIAS NOS FLUXOS INFORMACIONAIS (IFI)}

Regis Garcia

Bárbara Fadel

\section{Introdução}

A cultura formada a partir das relações individuais nas organizações é capaz de influenciar sobremaneira a eficácia operacional. Uma vez evidenciada no conjunto de crenças e valores, ela determina em parte quais os procedimentos aceitos como válidos e consequentemente expurga aqueles comportamentos não aderentes a seus pressupostos fundamentais.

A comunicação e os processos decisórios nas organizações, estabelecidos segundo os pressupostos culturais, são alimentados pelos fluxos informacionais que, por sua vez, são determinantes na forma com que os indivíduos percebem e agem a partir das informações que por eles transitam.

$\mathrm{O}$ alinhamento entre a percepção dos indivíduos e os objetivos organizacionais representa o desafio da gestão contemporânea que está em meio aos problemas relacionados ao acesso, à quantidade e à multiconceituação das informações.

A partir do diagnóstico da cultura e planejamento e implantação de ações de interferências nos fluxos informacionais, espera-se a minimização da dispersão de pensamento e ação dos indivíduos no contexto organizacional levando-os ao 
encontro do objetivo maior das organizações, quer seja o da continuidade.

\section{Cultura organizacional}

A cultura vista de forma geral, ou seja, não restrita às organizações, é um fenômeno que permeia todas as ações humanas. No contato com outros indivíduos vão sendo estabelecidas as "normas" intrínsecas de conduta e de comportamento. Esses padrões vão sendo compartilhados com outros membros entrantes e assim sucessivamente até que sejam fortalecidos e transformados em bases para a forma de pensar e agir do grupo.

Assim se dá o nascimento e desenvolvimento dos padrões de pensamento e comportamento, de forma que "qualquer unidade social que tenha algum tipo de história compartilhada terá desenvolvido uma cultura" ao longo do tempo (Schein, 2009, p.11).

As atividades humanas, em especial aquelas que redundam em algum tipo de relação entre indivíduos, são os elementos criadores e ao mesmo tempo modificadores da cultura. A cultura é dinâmica à medida que é influenciada por vários fatores, como pelo ambiente, pelos relacionamentos e pelas experiências individuais e coletivas.

Segundo Gallagher (2003, p.15), o termo cultura "tem sua origem na palavra culto, que se originou do termo latino para adorar", sendo que no contexto empresarial ele é usado para significar as "principais crenças, comportamentos e ações subjacentes à vida empresarial diária".

A cultura empresarial, ou organizacional para abranger outros tipos de entidades, é subjetiva, porém interfere concretamente no comportamento e nas ações dos membros das organizações. Não é possível se determinar o momento exato no qual a cultura surge, mas aparentemente ela emana da cultura individual do formador do grupo. É o que ocorre quando o empreendedor resolve constituir um negócio e imprime sua própria cultura ao grupo que liderará para atingir seus objetivos. 
Noutra situação, pode-se também considerar que a cultura pode sofrer modificações ao longo do tempo à medida que novas lideranças vão sendo trazidas para gerir o grupo ou os subgrupos formados a partir do desenvolvimento da organização.

Embora a cultura inicial seja totalmente influenciada pela liderança fundadora, a partir da escolha dos demais líderes, mesmo que o processo de seleção desses leve em conta os aspectos culturais atuais, haverá adaptações em níveis mais superficiais da cultura. É fato que o âmago da cultura permanecerá intacto, mas ao menos no nível dos artefatos se perceberá a influência da cultura da liderança entrante.

O nível de adaptação e modificação da cultura dependerá do quanto as ações fundamentadas na cultura do líder terão sucesso, mantendo assim o grupo coeso no sentido de aprovação das novas práticas, até que essas sejam incorporadas definitivamente e transformadas em elemento integrante da nova cultura organizacional modificada.

O surgimento da cultura organizacional, na opinião de Schein (2009), se dá inicialmente pela cultura imposta pela liderança. Ao mesmo tempo que ela redunda em sucesso do grupo e da organização, acaba por se tornar o parâmetro que norteará a definição das próximas lideranças; porém, se há problemas de adaptação do grupo, questionando a validade de suas suposições, novamente é a liderança que deverá agir sobre a cultura pela ação reflexiva e corretiva do líder.

Em constante processo de modificação e adaptação ela é em parte moldada pela forma como se dão os relacionamentos intragrupos, e ao mesmo tempo é determinante, em certa medida, dos comportamentos dos indivíduos. Esse ciclo é o que garante a evolução constante da sociedade e da cultura que lhe caracteriza evidenciando seu caráter dinâmico.

O compartilhamento do sentimento de que as visões, crenças e valores da liderança estão levando o grupo à obtenção de sucesso é o que determina a criação da cultura. À medida que o grupo vai experimentando o sucesso em relação a seus objetivos, o ciclo de repetição das ações baseadas nesses pressupostos vai confirmando de for- 
ma crescente que esses são adequados para nortear as próximas ações. Esse ciclo é interrompido sempre que haja um insucesso, quando então haverá uma reavaliação desses pressupostos.

A continuidade do grupo depende do alcance de dois objetivos, segundo Schein (2009): o primeiro relacionado ao desenvolvimento e o segundo, à adaptação. Os grupos experimentam os desafios de sobrevivência, crescimento e adaptação num primeiro momento, e o de alcançar a integração interna, num segundo, que viabilizará o funcionamento do grupo.

Se a cultura caracteriza um determinado grupo de indivíduos, como no caso das organizações, como toda caracterização ela possui elementos de maior ou menor evidência que fazem que seja rotulada a partir das características mais aparentes, o que nem sempre é eficaz para mostrar adequadamente como ela é na verdade em sua estrutura nuclear.

Schein (2009) critica a forma com que muitos estudos tratam o tema cultura organizacional. A tentativa de analisar a intensidade da cultura rotulando-a como forte ou fraca impede a análise mais profunda sobre o seu conceito. A maior preocupação do autor nesse sentido é em relação à sugestão de que há culturas "corretas" e "erradas" para as organizações.

É necessário ir mais a fundo no entendimento da cultura como conceito para que se compreendam seus reflexos nas ações concretas dos indivíduos e, consequentemente, dos grupos.

A cultura define algo mais profundo do que as características de operacionalização dos processos. Ela define, por exemplo, que comportamentos atrelados a esses devem ou não ser recompensados.

Para ilustrar essa dicotomia conceitual, do que é cultura empresarial e do que não necessariamente o é, elabora-se o Quadro 1.

A cultura estaria em nível superior em relação ao de conceitos como regras, valores e hábitos, uma vez que tais elementos determinam as ações dos indivíduos, mas não teriam força suficiente para caracterizar todo o grupo. Tão-somente determinam a forma do agir em determinadas situações cotidianas. A cultura é algo maior, ela caracteriza a forma do pensar e a aparência do grupo 
junto aos membros externos. Como se o grupo fosse o próprio reflexo de sua cultura.

Quadro 1 - Dicotomia conceitual da cultura empresarial

\begin{tabular}{|l|l|}
\hline CULTURA EMPRESARIAL É... & CULTURA EMPRESARIAL NÃO É.... \\
\hline Seus valores e crenças & Seus produtos e serviços \\
\hline Geralmente tácita & Promovida externamente \\
\hline Seu estilo & Suas políticas e procedimentos \\
\hline O tipo de pessoas contratadas & Seu processo de recrutamento \\
\hline Que comportamentos são recompensados & Que comportamento se afirma esperar \\
\hline
\end{tabular}

Fonte adaptada: Gallagher (2003, p.16).

\section{Parte modificável da cultura}

A cultura possui camadas que nem sempre podem ser vistas ou experimentadas pelos indivíduos externos ao grupo, ou até mesmo pelos indivíduos internos que não estejam envolvidos diretamente com determinadas ações conjuntas dos subgrupos em determinadas situações.

O que é possível perceber de uma cultura é apenas aquilo que pode ser traduzido em sinais significativos a partir das ações comportamentais dos indivíduos e dos grupos. No entanto, o núcleo da cultura não é incondicionalmente acessível e tampouco totalmente revelado pelas ações comportamentais do grupo e dos indivíduos.

É nesse nível que se espera que haja ações concretas de interferências capazes de alinhar cultura, comportamento e objetivos organizacionais.

Schein (2009), no entanto, esclarece que nem todas as regularidades comportamentais são manifestações da cultura, portanto as ações de Interferências nos Fluxos Informacionais (IFI) podem influenciar no compartilhamento da cultura sem, todavia, representar implicações na mesma proporção e no mesmo sentido no comportamento individual dos membros do grupo.

Tal consideração reforça a tese de que a perspectiva de controle atribuído à cultura não é plenamente justificável, ficando a parte 
referente ao comportamento individual motivado pelas características particulares que está fora do alcance absoluto de controle.

Ocorre que, ao se falar em interferência na parte modificável da cultura, considera-se que essa evidencia justamente aquilo que é compartilhado pelo grupo a ponto de se sobrepor às vontades individuais.

Nasce aí a necessidade de que haja um diagnóstico detalhado sobre a cultura do grupo e o nível de sua influência, positiva ou negativa, quanto à propensão à aceitação das interferências nos fluxos normais de informação. Como o indivíduo muitas vezes acaba por colocar em stand by seus pressupostos culturais em benefício da convivência e sobrevivência do/no grupo, pode ser mais importante a ação baseada na cultura organizacional do que fazê-lo pela tentativa de harmonização das culturas individuais.

Para a compreensão sobre qual interferência está em discussão no sentido de ação sobre os fluxos informacionais, é necessário primeiramente abordar os níveis de cultura a partir dos quais emanam as indicações de comportamento do grupo que, por sua vez, reflete a conduta dos indivíduos.

Uma das abordagens sobre os níveis de cultura é encontrada em Schein (2009), que a separa em três:

\section{Artefatos}

Representam os produtos visíveis do grupo, os aspectos perceptíveis a partir da observação e do contato humano. Vai desde a configuração do ambiente, passando por linguagem, criações artísticas, estilo de vestuário, formas de comunicação, de manifestações emocionais, entre outros.

\section{Crenças e valores expostos/assumidos}

Representa a evolução do nível de convencimento dos indivíduos em relação às crenças e valores pressupostos. Primeiramente as de- 
cisões sobre problemas levados ao grupo são pautadas pelas crenças e valores prévios daquele que sugere a conduta de ação.

As crenças e os valores assumidos são aqueles que, após experiências de sucesso pela aplicação destas percepções, passam a ser pressupostos de novas ações. Consequentemente, à medida que novas experiências vão validando esses pressupostos, mais fortemente essas crenças e valores estarão fundamentando as ações do grupo.

\section{Suposições fundamentais básicas}

Trata-se do nível no qual os valores que anteriormente consistiam em hipóteses, agora passam a fundamentar as ações sem serem questionados ou colocados em dúvida. É o resultado da repetição da implementação dos valores e crenças assumidos a ponto de se tornarem uma realidade.

As organizações sobrevivem a partir das atividades operacionalizadas pelos indivíduos que, por sua vez, em certa medida, agem pela influência de determinados pressupostos fundamentais. Elas "parecem funcionar principalmente em termos de algum núcleo de suposições, algum conjunto menor que pode ser imaginado como paradigma cultural, suposições governantes ou 'genes' críticos no 'DNA' cultural' (Schein, 2009, p.20, aspas do autor).

Com se pode ver, a parte da cultura evidenciada como artefatosé aquela na qual se podem exercer diretamente as ações de interferências na tentativa não de atuar sobre a cultura, mas com a anuência dessa a fim de centrar as percepções individuais nos objetivos organizacionais.

Se a partir dos conceitos compartilhados, depois de determinado tempo, essas ações descerem ao nível de valores e crenças expostos, isso deve ser encarado como consequência natural, mas não determinante da avaliação de sucesso das práticas de interferências exercidas. Essas têm sua validade constatada não pelo seu nível de aderência à cultura, mas pelo sucesso resultante da nova percepção focada nos objetivos da organização. 


\section{Fluxos informacionais (FI)}

Os Fluxos Informacionais (FI) são de vital importância para que as organizações e seus grupos de indivíduos sejam alimentados precisa e tempestivamente por informações alinhadas aos seus objetivos.

São as informações que subsidiam o processo de maior relevância no cotidiano organizacional, o decisório, e por isso são necessários canais adequados para que elas fluam adequadamente.

No contexto da sociedade contemporânea a importância e a relevância dos FI vêm crescendo, uma vez que o imperativo de manterse informado é condição para a manutenção do desenvolvimento constante e continuidade. Segundo Moura (2004, p.5), "A sociedade da informação caracteriza-se pelo elevado número de atividades produtivas que dependem da gestão de fluxos informacionais, aliado ao uso intenso de tecnologias e de comunicação e informação". Formase, portanto, a tríade: informação, fluxo, ação que norteia a atividade das organizações. A relação informação/fluxo informacional e seu aproveitamento no processo de geração de conhecimento culminam em ações efetivas que movem a estrutura organizacional.

Diante do fato de que a organização opera com base nas informações que detém, e cujos elementos compõem sua estrutura, seu mercado e seu negócio de forma geral, ela acaba se tornando dependente da circulação dessas informações entre seus membros, que lhes aplica processos cognitivos transformando-as em ações concretas.

Qualquer obstrução ou "poluição" do fluxo pela entrada de informações desconexas e irrelevantes poderá comprometer o bom andamento da organização. Soares (2010) destaca que o não funcionamento dos fluxos informacionais pode comprometer o funcionamento da instituição como um todo, não se restringindo ao comprometimento do processo de comunicação que representa apenas uma das funções dos FI.

Conceitualmente, pode-se descrever um fluxo informacional como sendo um canal - tangível ou intangível, formal ou informal, permanente ou esporádico, constante ou intermitente -, constituído pela circulação de informações que fluem de uma determinada 
origem, geralmente um suporte/indivíduo, em sentido a um destino de armazenamento/processamento, podendo ocorrer a reversão desse fluxo até que os objetivos inicialmente estabelecidos sejam atingidos.

Conforme Barreto (1998, p.122), um fluxo de informação pode ser compreendido como "uma secessão de eventos de um processo de mediação entre a geração da informação por uma fonte emissora e a aceitação pela entidade receptora...".

Para Moresi (2000), o fluxo de informação possui implicação mais abrangente do que a comunicação no contexto das organizações, representando, até mesmo, um processo de agregação de valor.

Geralmente os fluxos informacionais são tratados como elemento intrínseco aos sistemas de informações. Nesse sentido, os sistemas são considerados "como componentes fundamentais de uma organização social cuja principal característica é o intenso fluxo informacional, possibilitado, em grande parte, pelos estoques de documentos (em variados suportes)" (Unger \& Freire, 2008, p.95).

Por sua vez, a área de comunicação tem nos fluxos informacionais seu objeto de trabalho, especialmente na subárea de relações públicas que procura neles interferir no sentido de propiciar a divulgação eficaz dos assuntos de interesse da organização.

Os fluxos informacionais fluem, basicamente, em três direções: "do e para o interior da organização (informação circulando internamente); do interior da empresa para o exterior da organização (informação sendo comunicada ou divulgada); do exterior da empresa para o interior da organização (informação sendo recebida ou buscada)" (Freitas \& Janissek-Muniz, 2006, p.11).

Para fins de discussão sobre as IFI é importante a separação dos fluxos informacionais em formais e informais, e mais facilmente haverá interferência positiva nos fluxos formais, já que esses geralmente envolvem suportes tornando-os em parte mais palpáveis e modificáveis.

Segundo Valentim (2002), o fluxo informacional "perpassa formalmente as diferentes unidades de trabalho [...] por meio de memorandos, atas, relatórios, planilhas, e-mails etc.". 
Como no fluxo formal as informações transitam fisicamente, uma política de interferência passaria pela análise inclusive dos suportes informacionais.

\section{Interferências nos IFI}

Os fluxos informacionais, numa sociedade marcada pelo acesso fácil à informação, representam um elemento fundamental na gestão da comunicação e na viabilização das ações voltadas ao processo decisorial do ser humano.

Considera-se que as ações que visam a uma decisão, como é o caso da pesquisa informacional, pressupõem que os canais condutores estejam permitindo a fluidez das informações, bem como não sejam obstruídos por excessos informacionais não pertinentes aos objetivos decisórios das organizações.

Para gerenciar fluxos informacionais, "é necessário realizar ações integradas objetivando prospectar, selecionar, filtrar, tratar e disseminar todo ativo informacional e intelectual da organização" (Valentim, 2002, p.4).

Fica evidente que há um indicativo de ação concreta por parte da gestão da organização sobre o fluxo informacional. A ação sobre o fluxo, por sua vez, implica uma ação sobre seu conteúdo, já que não basta a correção dos artefatos ou dos meios tecnológicos para que se tenham resultados mais eficazes em termos de informação útil. Entende-se que sejam necessárias ações que envolvam também a gestão dos conteúdos, pois estes é que impactarão mais diretamente nos processos decisórios.

Por exemplo, para Bulegon (2007), os processos comunicacionais entendidos como atos de interação que se estabelecem a partir dos fluxos informacionais da organização são os responsáveis pela materialização das políticas e estratégias envolvendo os profissionais de relações públicas. A interação nesse caso envolve a troca de informações que circulam nos fluxos, porém de nada adiantaria para um profissional de relações públicas viabilizar o canal comunicacional 
adequado se o conteúdo que por ele transita não redunda em subsídio eficaz.

Os fluxos informacionais e seu conteúdo carecem de interferência toda vez que se perceba que na sua relação com os indivíduos resulta em informações e ações difusas em relação aos objetivos organizacionais. Eles devem servir especialmente aos objetivos da organização para depois expandirem sua contribuição para os demais propósitos do grupo que geralmente envolvem aspectos pessoais e sociais intra e extraorganizacionais.

Analisados apenas sob a óptica comunicacional, ou estritamente como meios tecnológicos, os fluxos informacionais estariam sendo resumidos ao conjunto de informações que transitam dentro da organização, de fora para dentro e de dentro para fora da mesma, sem um objetivo fixado e específico.

Há a necessidade de ser fixado como objetivo principal do fluxo informacional atender ao projeto de continuidade da organização. Todos os demais objetivos são consequências ou meios para isso. Sendo assim, os fluxos informacionais necessitam "serem bem geridos e reavaliados, por fazerem parte de um resultado maior" (Soares, 2010, p.3). Sem que se perca essa finalidade, qualquer ação de gerenciamento sobre ele pode transformar-se em interferência positiva e melhoria de eficácia.

A ação de gestão não deve se limitar aos artefatos possibilitados dos fluxos informacionais, mas deve agir sobre o próprio fluxo e seu conteúdo que é a informação. Portanto, a IFI pode ser considerada uma gestão da informação inerente aos fluxos, o que seria, por conceito, todo o processo ligado à "obtenção da informação adequada, na forma correta, para a pessoa indicada, a um custo adequado, no tempo oportuno, em lugar apropriado, para tomar a decisão correta" (Woodman e Ponjuan Dante apud Valentim, 2002).

Não é linear, é claro, o funcionamento dos fluxos informacionais a ponto de que bastaria um planejamento e o estabelecimento de ações de interferências sobre eles para se assegurar sua eficácia.

Cada tipo de organização suscita tipos diferentes de informações e fluxos internos que podem se alterar a cada momento pelo qual 
passa a organização. Segundo Kanaane (1995, p.29), a organização envolve "fatores dinâmicos que correspondem ao funcionamento dos subsistemas e ao processamento de informações".

Essa consideração ilustra o fato de que os fluxos informacionais pelos quais fluem as informações dentro das organizações se apresentam de forma diferente em cada ambiente e em cada situação. O caráter dinâmico do funcionamento dos subsistemas e do processamento das informações é reflexo do dinamismo do fluxo informacional.

Não apenas dinâmico é o fluxo, mas também o tipo e a qualidade das informações que nele transitam. Ao se aplicar um tipo de administração de controle mínimo sobre alguns aspectos operacionais, como tem sido a tendência nos últimos anos nas organizações, corre-se o risco de se alimentar um fluxo eclético, como se espera que o sejam no atual contexto social, porém com resultados dispersos.

A Figura 1 demonstra a difusão das informações após passarem pelo filtro perceptivo dos indivíduos. É certo que a não interferência no fluxo que leva essas informações ao indivíduo não é a única e tampouco a mais relevante razão dessa dispersão. Fatores comportamentais certamente são seus maiores influenciadores, porém, acredita-se que uma ação contínua e focada nos objetivos organizacionais poderia contribuir para a correção de parte dessa distorção. Ao menos naquela resultante da grande quantidade e dos multissignificados das informações que transitam nos fluxos.

Como se viu anteriormente, os processos de IFI devem passar pelo diagnóstico primário da cultura organizacional. Após o diagnóstico positivo sobre a aceitabilidade desse tipo de interferência é que as políticas deverão ser planejadas e implementadas. A justificativa desse diagnóstico será discutida na seção seguinte.

As ações de interferência sobre os fluxos se dão tanto nos meios como nos conteúdos e devem ser capazes de incutir no comportamento informacional dos indivíduos atitudes reflexivas e de ação voltadas sempre para o objetivo máximo da organização.

Depois de implementadas as políticas que envolvem essas duas camadas, o resultado deverá ser o de que a maior parte das informações que chegam aos indivíduos será de alguma forma relacionada 
aos objetivos da organização. As ações de filtragem, garimpagem, busca e oferta de informações passariam pelo sistema de IFI, que avaliaria por quesitos tecnicamente estudados a relevância e a aderência da informação ao conjunto de pressupostos relacionados aos objetivos da organização.

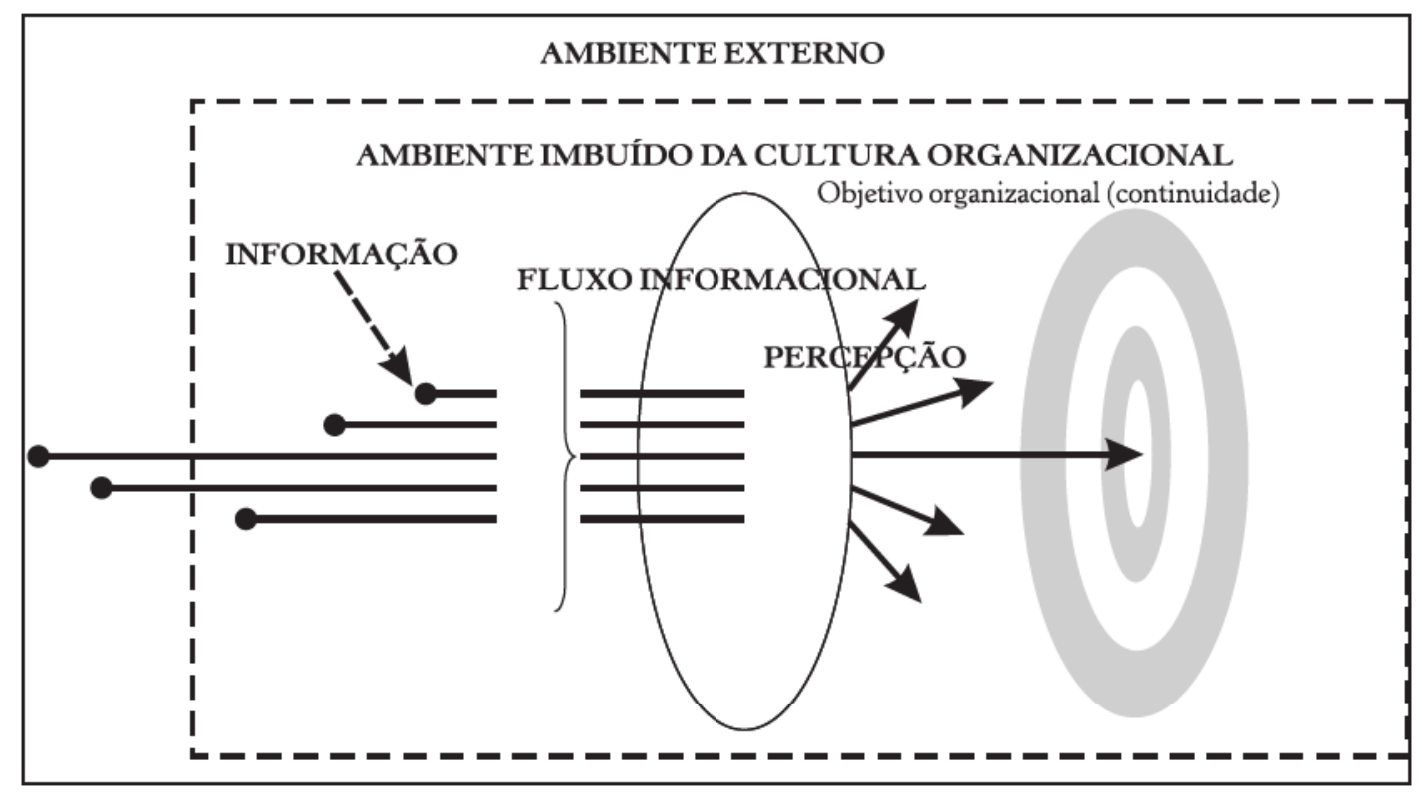

Figura 1 - Dispersão informacional.

Fonte: Elaborado pelos autores.

Similar ao processo proposto de IFI pode-se citar o que faz o jornalismo e suas subáreas com os fluxos informacionais dandolhes significado e levando-os aos objetivos predeterminados. Essas áreas "trabalham os fluxos informacionais, sejam eles mercadológicos ou institucionais, dando um tratamento à informação que vise direcionar esses fluxos, coordenando sua abundância e variedade em um processo integrado de comunicação" (Almeida \& Paula, 2005, p.7).

Embora se saiba que não é possível o controle de todas as variáveis relacionadas à condução dos pensamentos e ações aos objetivos organizacionais, espera-se que as IFI canalizem-nos nesse sentido, conforme se pode observar pela Figura 2. 


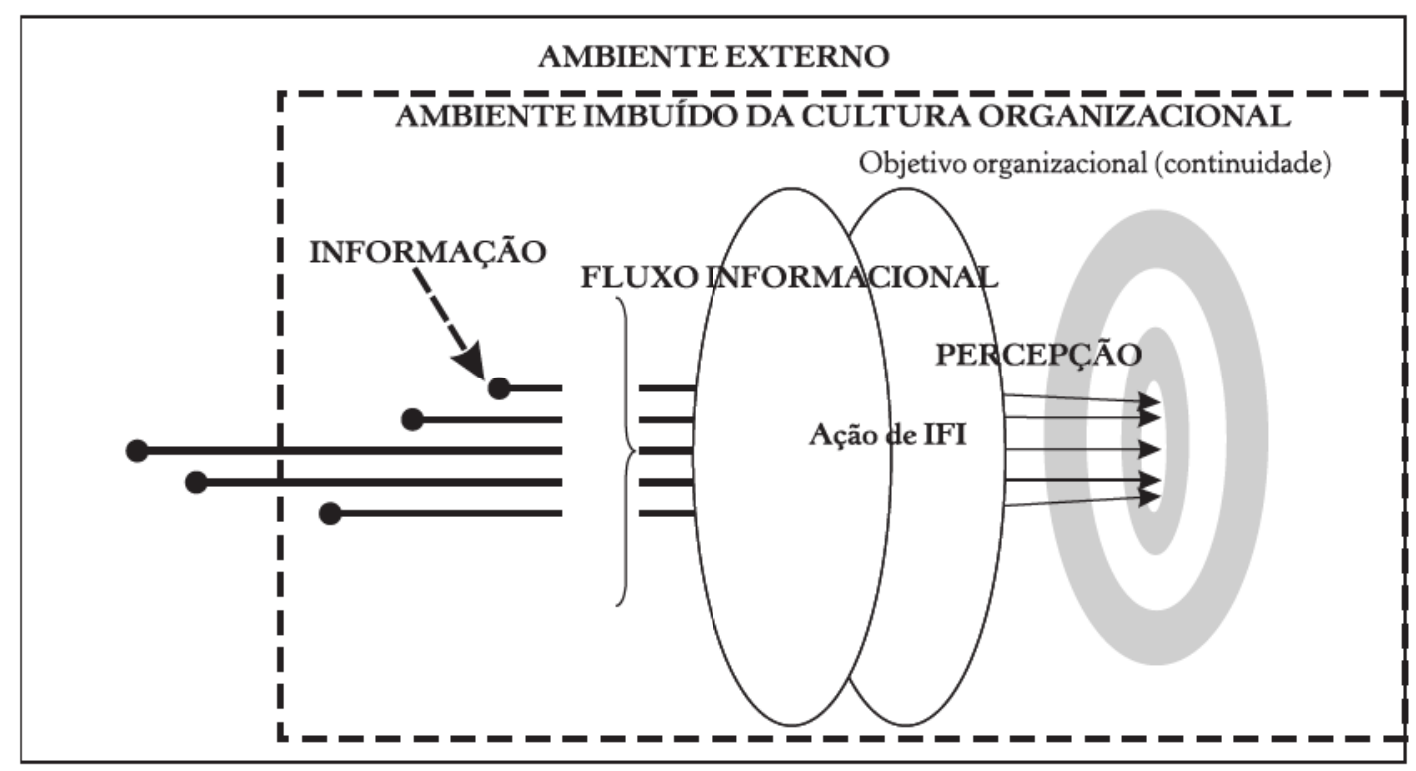

Figura 2 - Ação de IFI.

Fonte: Elaborado pelos autores.

Acredita-se que essa canalização seja possível à medida que pela ação efetiva sobre o fluxo é possível interferir no comportamento do indivíduo que com ele se relaciona.

As IFI funcionam como estímulos aos membros do grupo. Esses estímulos sugerem respostas que, se alinhadas aos primeiros, redundarão em ações focadas no objetivo organizacional. Kanaane (1995) diz que o comportamento do ser humano traduzido pela atitude implica "uma predisposição interior do indivíduo para reagir" em face das situações ocorridas no seu meio social.

\section{A linguagem}

A linguagem é um importante elemento a ser considerado no processo de IFI, já que é por meio dela que os indivíduos expressam seus pensamentos e ações. "A fixação de símbolos linguísticos a conceitos auxilia a aquisição e a transferência destes últimos" (Telford \& Sawrey, 1974, p.307).

Caberia à organização o estabelecimento de padrões internos de linguagem materializados nos demonstrativos econômico-financeiros, relatórios de avaliação de desempenho e outros instrumentos 
de comunicação de informações corporativas. Fazer que esse padrão seja aceito e resulte em objetividade de ação compreende o desafio das áreas relacionadas à gestão da informação e do conhecimento organizacional.

A linguagem traduzida por palavras funcionaria como um mecanismo de fixação dos conceitos necessários à ação em busca dos objetivos organizacionais. Como esclarecem Telford \& Sawrey (1974, p.308), "as palavras facilitam todos os aspectos da aquisição de conceitos".

\section{O ambiente e o clima organizacional}

Ações simples, como a disponibilização de murais contendo informações acerca de assuntos pertinentes aos objetivos organizacionais, podem exercer uma influência positiva nas ações individuais. Segundo Kolasa (1978, p.114), "o recebimento de informações, ou sensações, serve como uma base para o comportamento". A expressão recebimento por parte do indivíduo leva à necessidade de que haja o fornecimento pela outra parte envolvida na ação desejada, ou seja, a organização.

A interferência da organização no sentido de modificar o clima organizacional quando necessário é outro importante instrumento de ação pró-objetivo organizacional. O que se põe ou se permite circular no fluxo informacional afeta em certa medida o clima organizacional. Kolasa (1978) destaca a importância dos efeitos do ambiente próximo no desenvolvimento do indivíduo, que sobre influência de muitas forças. O conceito de ambiente próximo se refere àquele que envolve o indivíduo durante suas ações no contexto organizacional. Se a organização é em parte fruto da reunião de indivíduos, então cuidar desse ambiente afeta diretamente o desenvolvimento da organização como um todo. 


\section{Incentivo à aprendizagem}

Entre os mecanismos de modificação de comportamento pela aprendizagem podem-se destacar aqueles que se referem aos possíveis resultados obtidos pela interferência consciente nos fluxos. Esses mecanismos foram retirados de Kolasa (1978) e podem ser resumidos em:

- condicionamento - que se refere à modificação do comportamento por reações sucessivas a estímulos repetitivos;

- aprendizagem receptiva e discriminativa - que se assemelha ao conceito de tentativa e erro no qual as experiências positivas passadas determinam as escolhas futuras sendo que o mesmo ocorre no sentido das experiências negativa que são evitadas após a aprendizagem;

- aprendizagem conceitual ou por insight - que se dá pela conscientização repentina sem a necessidade de tentativa e erros prévios;

- motivação - que é considerada elemento essencial para o processo de aprendizagem;

- predisposição - que representa uma tendência ou inclinação do indivíduo a reagir aos estímulos de aprendizagem; e

- reforço - trata-se da recompensa pelas escolhas assertivas.

A defesa das IFI passa pelo entendimento de como se dá o raciocínio do ser humano, pois a ação depende da forma como esse se processa. Depende também da sua percepção sobre seu ambiente e as informações que nele circulam. Não há como atingir tão profundamente o ser humano, mas é possível exercer ações de incentivo que o leve a atingir níveis satisfatórios de informação (no sentido de estar informado) pelo estabelecimento de políticas que lhe esclareçam os reais objetivos envolvidos na sua relação com a organização.

O raciocínio presume a aquisição, a retenção, a separação e a recordação de conceitos pertinentes. O pensamento de um indivíduo é sempre limitado pela extensão, pelo completamente, pela exatidão, pela 
adequação e pela disponibilidade dos seus conceitos e informações. (Telford \& Sawrey, 1974, p.303)

\section{Influência da cultura nas IFI}

Qualquer ação de IFI interna de uma organização implica a consideração sobre o tipo de cultura que rege o ambiente. A depender de como a cultura é percebida, em que nível ela afeta as ações dos indivíduos do grupo e qual parcela desses está mais fortemente aculturada, ${ }^{1}$ será mais facilmente entendida e aceita qualquer interferência que se mostre voltada aos objetivos da organização.

Segundo Gallagher (2003, p.39), na visão dos estrategistas os procedimentos operacionais básicos são "um microcosmo de valores culturais que, por sua vez, os torna bem-sucedidos".

As soluções para os conflitos de interesse internos à organização, oriundos das ações impostas pela gestão ao implementarem suas políticas, passam, portanto, pelo entendimento da cultura individual e do grupo.

Independentemente de ser considerada no ambiente organizacional, a cultura explica muito sobre a forma com que os indivíduos veem e percebem os fenômenos à sua volta.

No próprio conceito de cultura estão presentes aspectos que remetem à ideia de influência direta no comportamento humano. Segundo Schein (2009), seriam características do conceito de cultura: i) a estabilidade, ii) a profundidade, iii) a extensão e iv) a padronização ou integração.

O primeiro termo se refere à capacidade de absorção das agressões à estabilidade cognitiva sofridas pelas mentes humanas. É uma tendência natural a aversão a qualquer ação que resulte em mudan-

1 Aculturação é aqui considerado o processo pelo qual a cultura do indivíduo entrelaça-se com a cultura do grupo, gerando uma nova cultura modificada que influencia mais fortemente as ações intraorganizacionais do que a própria cultura do indivíduo. 
ça de paradigma que esteja fundamentado no nível das suposições básicas. A estabilidade surge à medida que as crenças e valores se direcionam para o nível de supostos fundamentais básicos, conforme será discutido mais à frente.

O nível de aculturamento que está implícito no segundo termo é um determinante da força com que as crenças e valores estarão influenciando a ação do indivíduo no contexto organizacional. Quanto mais profundos forem os supostos norteadores das ações individuais, mais condizentes com a cultura estas últimas serão. Não pela ação em si, mas porque mentalmente o indivíduo estará convencido de que está agindo corretamente e de acordo com os princípios organizacionais por ele incorporados.

$\mathrm{O}$ aspecto de extensão representa similarmente à profundidade $\mathrm{a}$ abrangência da cultura, porém em termos da parcela de indivíduos por ela influenciados e qual a parcela de aculturados dentro do grupo. Quanto maior essa parcela, mais integrado é o grupo. Kolasa (1978, p.127) considera que "as atitudes das diferentes camadas da sociedade [...] concorrem para moldar a pessoa de acordo com seu nível de agrupamento".

Os dois últimos termos dizem respeito às consequências dos três primeiros, uma vez que, a depender do nível de estabilidade, da profundidade dos valores norteadores de comportamento e da extensão de influência da cultura, confirmados pelas ações dos indivíduos no grupo, mais padronizado e integrado esse estará.

Quando se trata de interferência nas ações individuais dentro do grupo, como é o caso no processo de aprimoramento das políticas e tecnologias de comunicação interna, a análise prévia da cultura se torna elemento fundamental para sua garantia de aceitação.

O compartilhamento das suposições culturais torna o processo de manutenção da cultura algo mais tangível. À medida que se possibilita o compartilhamento da cultura por meio da intervenção focada dos fluxos informacionais no contexto atual do grupo, permite-se que membros entrantes acessem a parte revelável da cultura, agregando-lhes mais facilmente os pressupostos culturais que regem o ambiente. 
Para Schein (2009), o compartilhamento das suposições permite a sobrevivência da cultura pela transmissão aos novatos, porém o não compartilhamento tornaria o processo de construção da cultura algo mais criativo a partir da interação entre os membros antigos e os novatos do grupo.

Restaria uma análise nesse caso sobre a eficácia de uma ou outra situação na condução do grupo ao encontro de seus objetivos. Num primeiro momento, parece que culturas vencedoras sugeririam um compartilhamento maior do que aquelas com indícios de conturbação ambiental, nebulosidade comunicacional e desmotivação, características essas inibidoras das ações que resultariam em sucesso do grupo.

Partindo desse pressuposto, seria importante que a liderança estivesse em constante alerta em relação ao sucesso e insucesso do grupo em relação às metas que os conduzem aos objetivos estabelecidos. Uma vez certo de que a manutenção da cultura organizacional tal como se apresenta é positiva nesse sentido, então ações de IFI poderiam servir de instrumento de compartilhamento das suposições, preferencialmente, evidenciando-as concretamente nos artefatos tecnológicos disponíveis.

A crítica a essa visão se daria por conta daqueles que não concordam com o fato de que a cultura seria uma forma de controle social, e assim qualquer ação de interferência que vise sua manutenção (manipulação) seria igualmente mecanismo de controle.

Esse é o ponto que se considera fundamental nesta discussão. Quando se trata de organizações com objetivos concretos e previamente definidos, as ações de controle social e ambiental são consideradas como estratégicas e necessárias à consistência do grupo. Quanto menos controladas as variáveis comportamentais internas à organização, menos coerentes serão os comportamentos individuais no sentido estrito dos objetivos almejados pelo grupo, já que lhes faltaria um "fio condutor".

A metáfora de uma corrente elétrica que necessita da garantia de fluidez em direção ao seu objetivo de consumo poderia muito bem representar esse pensamento. $\mathrm{Na}$ ausência ou inadequabili- 
dade do elemento condutor, há a ineficácia, e, quando não, a sua interrupção.

O controle do fluxo informacional traria as pontas soltas das ações individuais para o centro da cultura vencedora garantindo sua manutenção nas condições que a faz eficaz para a coesão do grupo, tornando-o a cada novo ciclo mais convencido de que o conjunto de pressupostos culturais é o mais adequado no contexto ambiental do momento.

Essas considerações evidenciam o fato de que as ações dos indivíduos, mesmo as de repúdio e resistência a políticas internas, são fortemente influenciadas pela forma com que esses percebem e experimentam a cultura organizacional. É evidente a interferência da cultura na percepção do indivíduo em relação às práticas organizacionais internas, como no caso da comunicação viabilizada pelos fluxos informacionais.

Torna-se fundamental, então, que haja primeiro o diagnóstico da cultura para, na sequência, se estabelecerem na prática políticas que farão do relacionamento dos indivíduos com os fluxos informacionais uma ação voltada para a busca do objetivo organizacional. A partir dessas considerações, elabora-se a representação da IFI com base no diagnóstico da cultura, demonstrado na Figura 3.

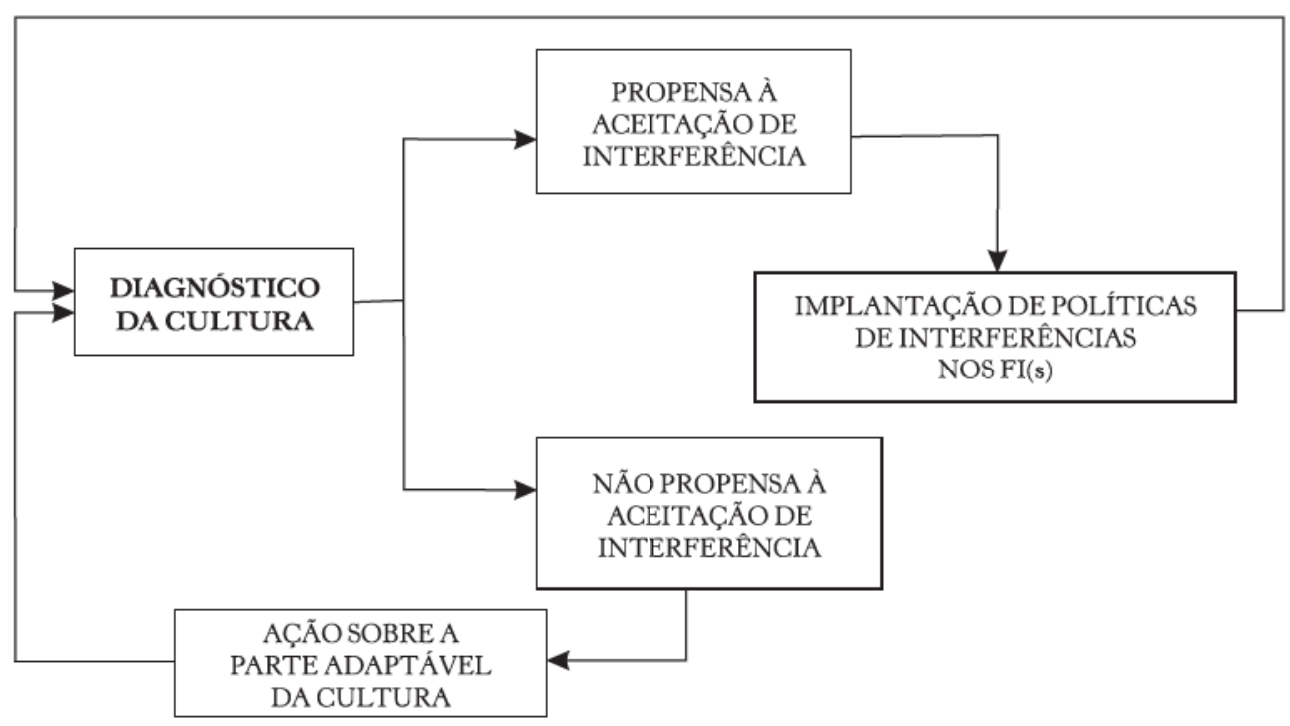

Figura 3 - Fluxo da IFI com diagnóstico da cultura.

Fonte: Elaborado pelos autores. 
A Figura 3 demonstra que a IFI começa com o diagnóstico da cultura no sentido de identificar a propensão à aceitação das interferências. Uma vez diagnosticada essa propensão, elaboram-se o planejamento e a implantação das políticas de IFI fechando o ciclo com o diagnóstico constante da cultura que sofrerá influência das mudanças ocasionadas pelas interferências. Na hipótese de o diagnóstico indicar a não propensão à aceitação das IFI, devem-se primeiramente desenvolver ações de modificação da parte adaptável da cultura.

Dessa forma, considera-se que a partir de uma cultura propensa à aceitação das interferências nos fluxos internos informacionais é que se tornam possíveis determinadas ações concretas que redundam em práticas que atualmente são definidas como gestão da informação, gestão do conhecimento, inteligência competitiva, entre outras.

Em meio às discussões relacionadas à gestão das práticas que envolvem a informação como objeto há que discutir adicionalmente e talvez previamente a questão das IFI.

É por meio das IFI que as organizações atraem os esforços dispensados nos processos de gestão da informação, gestão e criação do conhecimento e para a aquisição de inteligência competitiva, para um fórum de debate e planejamento de ações centrado no principal objetivo corporativo, quer seja a continuidade.

\section{Considerações finais}

A cultura organizacional representa o elemento norteador do comportamento dos indivíduos dentro de grupo. Ela é percebida não por meio do conhecimento e evidenciação de seu núcleo que muitas vezes é inatingível, mas por artefatos, crenças e valores expostos.

É nesse nível que são possíveis ações de interferências que contribuam para que as IFI se tornem uma realidade na organização.

A desconsideração das características culturais implicaria o risco de agir contrariamente ao que os indivíduos consideram como ações 
válidas segundo as suposições fundamentais básicas sob as quais percebem os fenômenos organizacionais.

A partir do diagnóstico da cultura é possível que sejam planejadas e implantadas políticas de IFI ou que, antes disso, se desenvolvam ações de adaptação da cultura em seu nível modificável com a finalidade de canalizarem os pensamentos e ações dos indivíduos para os objetivos da organização.

Os resultados esperados a partir das IFI não são lineares, já que outros fatores devem compor as estratégias de controle dos fluxos.

Outras variáveis importantes que interferem no comportamento do indivíduo em contato com o fluxo informacional devem ser estudas para que se fortaleça o conteúdo teórico que poderia descrever e/ou explicar as dispersões de pensamento e ações dentro das organizações. Não obstante, é por meio das IFI que se espera conduzir o conteúdo dos fluxos e seus resultados para a garantia de continuidade da organização.

\section{Referências}

ALMEIDA, I. L.; PAULA, C. F. C. Comunicação organizacional e relações públicas: caminhos que se cruzam, entrecruzam ou sobrepõem? In: CONGRESSO BRASILEIRO DE CIÊNCIAS DA COMUNICAÇÃO (Intercom), 28, Rio de Janeiro, set. 2005. Anais... Disponível em:<http://www.rp-bahia.com.br/biblioteca/ intercom2005/R1353-1.pdf>. Acesso em: 21 mar. 2010.

BARRETO, A. Mudança estrutural no fluxo de conhecimento: a comunicação eletrônica. Ciência da Informação, Brasília, v.27, n.2, p.122-7, mai./ago. 1998. Disponível em: <http:// www.revista.ibict.br/index.php/ciinf/article/viewFile/340/301>. Acesso em: 15 mar. 2010.

BULEGON, B. M Gestão da informação e o processo de comunicação: qual a função das relações públicas? In: CONGRESSO BRASILEIRO DE CIÊNCIAS DA COMUNICAÇÃO DA REGIÃO SUL (Intercom), 8, Passo Fundo (RS), maio 2007. Disponível em: <http:/ 
/www.intercom.org.br/papers/regionais/sul2007/resumos/ R0135-2.pdf $>$. Acesso em: 15 fev. 2010.

FREITAS, H.; JANISSEK-MUNIZ, R. Uma proposta de plataforma para inteligência estratégica. In: ENCONTRO NACIONAL DA ABRAIC; CONGRESSO IBERO-AMERICANO DE GESTÃO DO CONHECIMENTOE INTELIGENCIA COMPETITIVA, 3, Curitiba, 2006. Anais... Curitiba, 2006. Disponível <http:// www.ieabrasil.com.br/ieabrasil/arquivos/biblioteca/ bib_artigos_1.pdf $>$. Acesso em: 15 mar. 2010.

GALLAGHER, R. S. Os segredos da cultura empresarial: como entender a alma das culturas organizacionais bem-sucedidas. Rio de Janeiro: Campus, 2003. 269p.

KANAANE, R. Comportamento humano nas organizações: o homem rumo ao século XXI. São Paulo: Atlas, 1995.

KOLASA, B. J. Ciência do comportamento na administração. Rio de Janeiro: Livros Técnicos e Científicos, 1978. 623p.

MORESI, E. A D. Delineando o valor do sistema de informação de uma organização. Ciência da Informação, Brasília, v.29, n.1, p.1424, jan./abr. 2000. Disponível em: <http://www.scielo.br/pdf/ci/ v29n1/v29n1a2.pdf>. Acesso em: 22 mar. 2010.

MOURA, M. A. Leitor-bibliotecário: interpretação, memória e as contradições da subjetividade. Perspectivas em Ciência da Informação, Belo Horizonte, v.9 n.2, p.158-69, jul./dez. 2004. Disponível em: <http://www.eci.ufmg.br/pcionline/index.php/pci/article/ viewFile/357/166>. Acesso em: 15 fev. 2010.

SCHEIN, E. H. Cultura organizacional e liderança. São Paulo: Atlas, 2009. 413p.

SOARES, V. D. Fluxo de informação x relações do poder: jogo empatado. Biblioteca On-Line de Ciência da Comunicação. Disponível em: $<$ http://www.bocc.ubi.pt/ bocc/pag/soares-valeria-fluxosinformacao.pdf>. Acesso em: $1^{\circ}$ mar. 2010.

TELFORD, C. W.; SAWREY, J. M. Psicologia: uma introdução aos princípios fundamentais do comportamento. São Paulo: Cultrix, 1974. 530p.

UNGER, R. J. G.; FREIRE, I. M. Regimes de informação na sociedade da informação: uma contribuição para a gestão. Revista Digital de Biblioteconomia e Ciência da Informação, Campinas, v.2, n.2, p.87114, jan./jun. 2008. 
VALENTIM, M. L. P. Inteligência competitiva em organizações: dado, informação e conhecimento. DataGramaZero - Revista de Ciência da Informação, Rio de Janeiro, v.3, n.4, ago. 2002. Disponível em: <http://www.dgz.org.br/ago02/Art_02.htm>. Acesso em: $10 \mathrm{fev}$. 2010. 


\title{
11 \\ INFORMAÇÃO E CONHECIMENTO NO CONTEXTO DE AMBIENTES ORGANIZACIONAIS
}

\author{
Luciane de Fátima Beckman Cavalcante \\ Marta Lígia Pomim Valentim
}

\section{Introdução}

Tendo em vista que espaço informacional segundo Almeida Jr. (2008) "se constitui ao mesmo tempo como objeto e sujeito da história e do destino da sociedade", podemos caracterizar as organizações corporativas também como um espaço informacional, ao passo que influenciam e são influenciadas pelo ambiente no qual estão inseridas. Bem como são produtoras e receptoras de dados, informação e conhecimento, tanto do seu meio interno quanto do meio externo a elas.

A informação e o conhecimento direta ou indiretamente estão presentes em todos os processos e atividades organizacionais, logo se entende que, ao absorver e utilizar da melhor forma possível esses recursos, as organizações tendem a obter um melhor desenvolvimento e competitividade ante o mercado. Ressalta-se que as organizações são permeadas por intensos fluxos informacionais, tanto internos quantos externos a elas, fator importante para a compreensão da dinâmica organizacional.

Pelo exposto, o presente capítulo aborda o escopo do ambiente organizacional, explorando a relevância da informação e do conhecimento nesse contexto, discutindo ainda a questão do comportamento informacional nesse ambiente. 


\section{Ambiente organizacional}

As organizações são compostas de infraestrutura, pessoas e tecnologias, elementos permeados pela informação. As organizações empresariais estão em constante interação com dois tipos de ambientes, o interno e o externo, os quais são abarcados por ambientes informacionais.

O ambiente interno, também chamado de microambiente, se relaciona aos processos organizacionais, infraestrutura, tecnologia, produtos e serviços, relacionamentos que a organização mantém com terceiros etc. $\mathrm{O}$ ambiente conhecido também como macroambiente compreende tudo que possa interferir ou exercer influência no desenvolvimento dos processos organizacionais.

O microambiente consiste em forças próximas à empresa e que afetam sua capacidade de servir seus clientes: a própria empresa, os fornecedores, os canais de marketing, os mercados de clientes, os concorrentes públicos. O macroambiente consiste em forças sociais maiores que afetam todo o microambiente - forças demográficas, econômicas, naturais, tecnológicas, políticas e culturais. (Kotler \& Armstrong, 1998, p.47)

As organizações possuem uma estrutura organizacional à qual está relacionada, segundo Valentim (2005), "a organização das atividades, funções e autoridades necessárias para atingir um determinado objetivo e missão". A estrutura organizacional é essencial para o desenvolvimento concreto do processo organizacional, tal estrutura dividese em dois tipos, estrutura formal e estrutura informal. A estrutura formal, de acordo com Oliveira (2001, p.82), "é aquela deliberadamente planejada e formalmente representada, em alguns de seus aspectos, pelo organograma", ou seja, é a estrutura que de alguma forma é instituída. Por sua vez, a estrutura informal, segundo o referido autor, relaciona-se "à rede relações sociais e pessoais", ou seja, ocorre de forma espontânea, derivando da interação dos indivíduos.

A estrutura organizacional é composta de níveis que lhe conferem sustentabilidade, os chamados níveis organizacionais. As orga- 
nizações são diferenciadas em três níveis organizacionais. São eles, na visão de Chiavenato (2003, p.525-6):

- Nivel institucional ou estratégico: corresponde ao nível mais elevado e é composto de diretores, proprietários ou acionistas e dos executivos. É o nível em que as decisões são tomadas e onde são definidos os objetivos da organização e as estratégias para alcançá-los. É basicamente extrovertido, pois mantém a interface com o ambiente.

- Nível intermediário: também chamado de nível mediador ou gerencial, é o nível colocado entre o institucional e o operacional e que cuida da articulação interna entre ambos. Atua na escolha e captação dos recursos necessários, bem como na distribuição e colocação do que foi produzido pela empresa nos diversos segmentos do mercado. É o nível que lida com os problemas de adequação das decisões tomadas no nível institucional (no topo) com as operações realizadas no nível operacional (na base da organização). O nível intermediário compõe-se da média administração, isto é, das pessoas ou órgãos que transformam as estratégias formuladas para atingir objetivos empresariais em programas de ação.

- Nivel operacional: denominado nível técnico ou núcleo técnico, é o nível localizado nas áreas inferiores da organização. Está ligado aos problemas de execução cotidiana e eficiente das tarefas e operações da organização e orientado para as exigências impostas pela natureza da tarefa técnica a ser executada, com os materiais a serem processados e a cooperação de vários especialistas necessários ao andamento dos trabalhos. É o nível no qual as tarefas são executadas e as operações realizadas: envolve o trabalho básico relacionado com a produção de produtos ou serviços da organização. É nele que estão as instalações físicas, máquinas e equipamentos, linhas de montagem, escritórios e balcões de atendimento cujo funcionamento deve atender às rotinas e aos procedimentos programados dentro de uma regularidade e continuidade que assegurem a utilização plena dos recursos disponíveis e a máxima eficácia das operações.

Os níveis organizacionais também são conhecidos como níveis de influência da estrutura organizacional e, de acordo com Oliveira (2001, p.102), "estão relacionados aos tipos de planejamento" exis- 
tentes na empresa. Pode-se também abranger os níveis estratégico, tático e operacional em níveis de informação e de decisão na empresa, como abordam Rezende \& Abreu (2003, p.130). Segundo os referidos autores, "o tipo de decisão que é tomado em cada nível requer um grau diferente de agregação da informação, e os diferentes níveis de decisão requerem diferentes informações".

Pode-se notar que os níveis citados são de certo modo interligados, um apoia o desenvolvimento do outro, cabendo ao nível operacional fornecer sustentação aos demais, visto que é pelo nível operacional que todas as tarefas destinadas pelo nível estratégico são desenvolvidas.

Pelo exposto, observa-se que cada nível tem o seu grau de impacto no desenvolvimento organizacional, logo o comportamento informacional dos indivíduos pertencentes a tais níveis pode influir de modo decisivo nas estratégias organizacionais. Portanto, é preciso que a organização possua ou desenvolva uma cultura informacional ${ }^{1}$ positiva em relação ao compartilhamento da informação e do conhecimento pelos atores organizacionais em todos os níveis organizacionais.

\section{Informação e conhecimento no contexto organizacional}

O conhecimento reside no ser humano, ele advém de diferentes processos cognitivos, de experiências vividas, de informações adquiridas. Quando o conhecimento não é explicitado, isto é, é parte somente de quem o possui, a literatura apresenta-o como "conhecimento tácito”. A partir do momento em que o conhecimento é explicitado - na forma de símbolos, signos ou objetos -, a literatura apresenta-o como "conhecimento explícito". Para melhor compreen-

1 O conceito de cultura informacional, bem como o de cultura organizacional, será abordado mais à frente, neste capítulo. 
são acerca desses conceitos, observa-se como base a definição de Choo (2003, p.37):

Conhecimento tácito é conhecimento pessoal, que é difícil de formalizar ou comunicar aos outros. É constituído do kow-how subjetivo, dos insights e instituições que uma pessoa tem depois de estar imersa numa atividade por um longo período de tempo [...] Conhecimento explícito é o conhecimento formal que é fácil transmitir entre os dois indivíduos e grupos. É frequentemente codificado em fórmulas matemáticas, regras, especificações e assim por diante.

Compreende-se que o conhecimento tácito e o conhecimento explícito são complementares, um precisa do outro para existir, ou seja, quando o conhecimento tácito torna-se explícito, esse por sua vez faz surgir um novo conhecimento tácito, formando assim uma espiral contínua de conhecimento.

Sendo o conhecimento tácito algo que reside nas pessoas e essas, por sua vez, se constituem no centro condutor da organização, fazse necessário explicitar tal conhecimento, com o objetivo de se obter um melhor desempenho organizacional por parte dos colaboradores, bem como da própria organização.

Tudo o que a organização conhece tem suas raízes no conhecimento tácito. É difícil verbalizar o conhecimento tácito usando linguagem ou símbolos. É difícil decompô-lo em elementos, estágios ou regras, por que ele se distribui em sua totalidade das experiências individuais. (Choo, 2003, p.387)

Uma organização não gera conhecimento por si só, ela depende da iniciativa dos indivíduos que nela atuam, e da interação que ocorre dentro do grupo (Moresi, 2001, p.36), ou seja, a criação do conhecimento organizacional está totalmente relacionada aos indivíduos pertencentes a ela, bem com a interação entre os indivíduos. De acordo com Belluzzo \& Feres (2003, p.3): 
$\mathrm{Na}$ era da globalização somente pelo conhecimento embutido em seus produtos e serviços as empresas poderão vencer concorrentes e sobreviver. A concorrência não está mais limitada a uma concessão de preços, mas, sim, à diferenciação de produtos e serviços, oferecendo qualidade ao cliente. $\mathrm{E}$ isso só pode ser obtido pelo bom emprego do conhecimento que reside nas pessoas envolvidas na organização.

De acordo com Nonaka \& Takeushi (1997, p.65), uma organização não consegue criar conhecimento sem o ator humano. Desse modo, ela "deve identificar e motivar indivíduos criativos a compartilharem conhecimentos, e para isso deve fornecer-lhes os meios e contextos apropriados para explicitarem o seu conhecimento". Para que as pessoas exteriorizem parte de seu conhecimento tácito, é necessário criar condições para o compartilhamento de experiências e informação, o que proporciona nova necessidade informacional, bem como novo conhecimento.

Entende-se conhecimento como aquele gerado por um sujeito cognoscente, é único, dependente de estruturas teóricas e práticas que possibilitarão sua construção. No entanto, acredita-se que o conhecimento somente será construído a partir de sua socialização. Essa dinâmica é que permite ao outro conhecer o conhecimento e, portanto, construir novo conhecimento. (Valentim \& Gelinski, 2006, p.115)

Desse modo, compreende-se que o conhecimento organizacional é formado pelo conhecimento tácito gerado pelo indivíduo e explicitado à organização, sendo tal conhecimento o ativo mais importante da organização. Sobre esse aspecto, Belluzzo \& Feres (2003) argumentam que:

Uma organização do conhecimento representa tanto o conhecimento explícito quanto o tácito, proporcionando vantagens competitivas nas organizações, e não está relacionado com quantidade de informação obtida/estocada, e sim em fazer uso inteligente da mesma. 
Observa-se que, assim como em qualquer outro contexto, no âmbito organizacional a construção de conhecimento é intensa, ocorrendo informalmente. O que propicia essa construção são elementos como a aprendizagem contínua, os relacionamentos interpessoais, entre clientes e fornecedores, as próprias experiências vividas pelos indivíduos. Nesse sentido, é possível perceber que "cada vez mais as organizações construirão conhecimento por meio dos seus relacionamentos com os empregados, fornecedores, clientes, comunidades nas quais operam e mesmo com seus concorrentes" (Bukowitz \&Willians, 2002, p.277).

Bukowitz \& Williams (2002, p.211) argumentam que "as organizações baseadas no conhecimento entendem que os empregados não são úteis apenas pelo que sabem, mas pelo que continuam a aprender”. Segundo Moresi (2000, p.14), “a importância da informação para as organizações é universalmente aceita, constituindo [...] pelo menos um dos recursos cuja gestão e aproveitamento estão diretamente relacionados com o sucesso desejado".
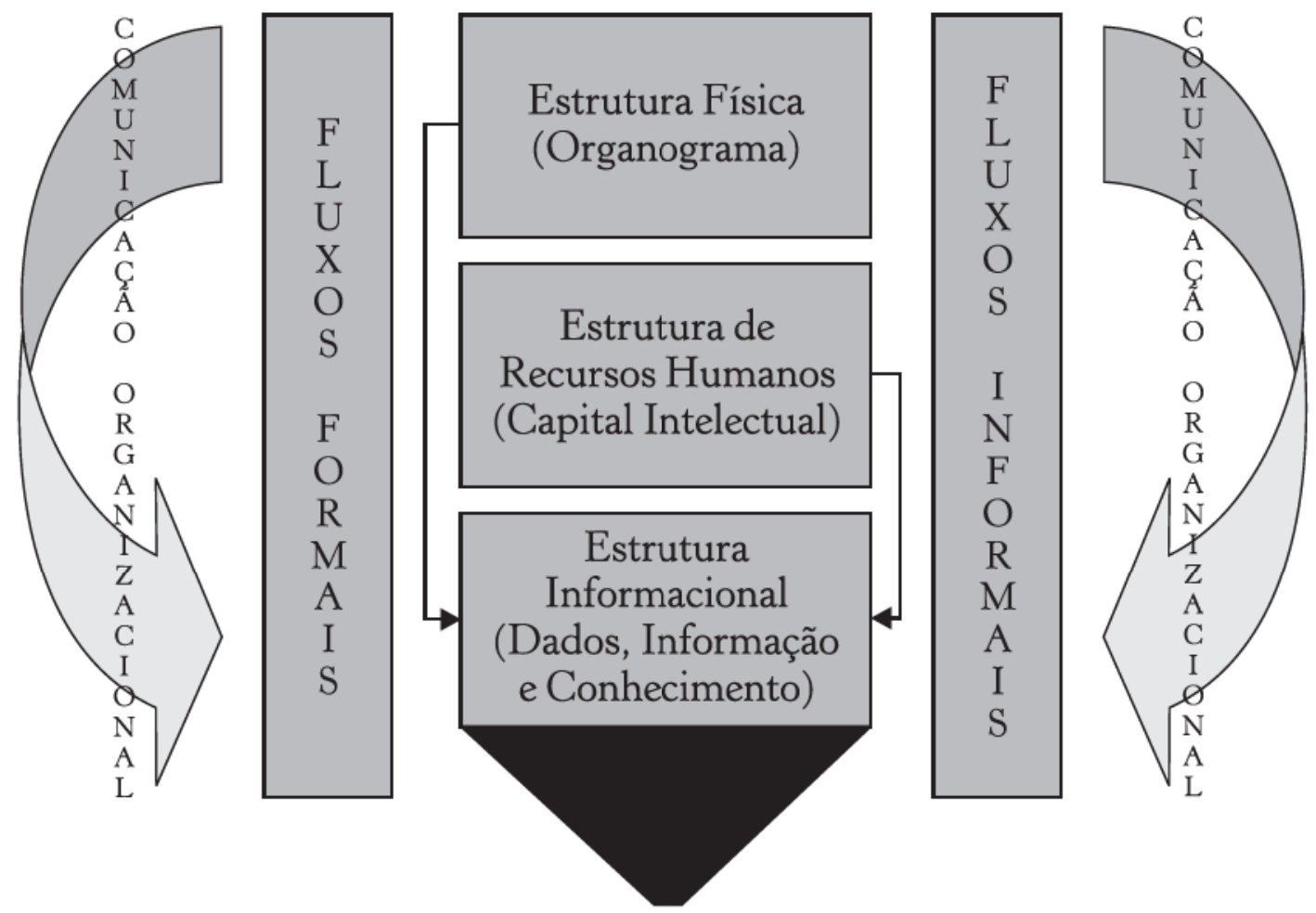

Figura 1 - Fluxos formais e informais.

Fonte: Valentim (2006, p.14). 
No âmbito organizacional, os fluxos informacionais são divididos em dois, a saber: o fluxo formal, referente a toda informação que circunda os níveis formais da organização, e o fluxo informal, referente à informação "gerada" no âmbito das relações interpessoais, como se pode observar na Figura 1.

Corrobora-se com a afirmação de Beal (2008, p.75) de que a informação é um fator essencial ao desenvolvimento organizacional.

A informação é um elemento essencial para a criação, implementação e avaliação de qualquer estratégia. Sem o acesso a informações adequadas a respeito das variáveis internas e do ambiente onde a organização se insere, os responsáveis pela elaboração da estratégia não têm como identificar os pontos fortes e fracos, as ameaças e oportunidades, os valores corporativos e toda variedade de fatores que devem ser considerados na identificação de alternativas e na tomada de decisões estratégicas.

A informação e o conhecimento direta ou indiretamente estão ligados a quase todos os processos organizacionais, pode-se afirmar que informação e conhecimento são fatores estratégicos ao desenvolvimento organizacional. Sobre esse aspecto, Choo (2003, p.27) explica:

A informação é um componente intrínseco de quase tudo que uma organização faz. Sem uma compreensão dos processos organizacionais pelos quais a informação se transforma em percepção, conhecimento $e$ ação, as empresas não são capazes de perceber a importância de suas fontes e tecnologias de informação.

Desse modo, percebe-se que as organizações podem usar a informação de forma estratégica, visando, uma ou várias ações. Para tanto, Choo (2003, p.45) explica que, para isso ocorrer, é preciso criar significado, construir conhecimento e tomar decisões. Uma “organização do conhecimento”, segundo Choo (2003, p.51), estaria ligada aos três processos de uso estratégico da informação - como anteriormente abordado - "num ciclo contínuo de aprendizagem e adaptação que se pode chamar de ciclo do conhecimento". Ainda 
sob o ponto de vista do mesmo autor, "a organização do conhecimento possui informações e conhecimentos que a tornam bem informada e capaz de percepção e discernimento".

De acordo com Chiavenato (2003, p.583), "o conhecimento ficou na dianteira de todos os demais recursos organizacionais, pois todos eles passaram a depender do conhecimento", incumbindo assim a relevância do conhecimento para o contexto organizacional e especialmente a necessidade dos gestores voltarem mais atenção a esse insumo.

Cabe ressaltar que o direcionamento da informação e do conhecimento no contexto organizacional - e por que não dizer em qualquer contexto - perpassa o fator humano. Como aborda Chiavenato (2003, p.593), "conhecimento é a informação estruturada que tem valor para a organização [...] são as pessoas que aprendem, desenvolvem e aplicam conhecimento na utilização adequada dos recursos organizacionais".

Sob esse aspecto, Valentim et al. (2008, p.12-13) argumentam que "a geração de conhecimento somente é possível quando a informação é interiorizada pelo sujeito, propiciando, por meio do estabelecimento de relações cognitivas, novo conhecimento, que pode ser aplicado". Desse modo, pela afirmação referida pode-se denotar que o conhecimento torna-se conhecimento a partir do momento que uma informação é internalizada pelo indivíduo, denotando novamente a fundamental importância do fator humano.

Valentim (2006, p.13-14) aborda os tipos de informações que estão presentes no ambiente organizacional:

- Informação estratégica, que apoia o processo de tomada de decisão e possibilita à alta administração da organização definir e planejar as estratégias de ação de médio e longo prazos.

- Informação voltada ao negócio, que possibilita ao nível tático da organização definir ações de curto prazo, bem como observar oportunidades e ameaças para o negócio corporativo.

- Informação financeira, que apoia as atividades desenvolvidas pelos profissionais da área financeira para que processem estudos de custos, lucros, riscos e controles. 
- Informação comercial, que subsidia as pessoas da área comercial nos processos relacionados à exportação e/ou importação de materiais, produtos e serviços; que subsidia também as pessoas da área jurídica no que diz respeito à legislação do país no qual se estabelece determinada transação comercial.

- Informação estatística, que subsidia várias áreas da organização, por meio de séries históricas, estudos comparativos, apresentando percentuais e/ou números relacionados ao negócio da organização.

- Informação sobre gestão, que atende às necessidades dos gerentes e executivos da organização no planejamento e gerenciamento de projetos, na gestão de pessoas etc.

- Informação tecnológica, que tanto subsidia as pessoas da área de pesquisa e desenvolvimento $(\mathrm{P} \& \mathrm{D})$ na criação e no desenvolvimento de produtos, materiais e processos, por meio do monitoramento da concorrência referente às inovações de produtos, materiais e processos, como apoia a implantação dos sistemas de qualidade no ambiente organizacional.

- Informação geral, que subsidia todas as áreas da organização, possibilitando aos profissionais que nela atuam a atualização constante.

- Informação "cinzenta" de qualquer natureza, para qualquer área e com qualquer finalidade de uso; esse tipo de informação não é detectado em buscas formais, podendo-se citar, como exemplo, colégio invisível, documentos confidenciais em difícil acesso, redes de relacionamento etc.

Beal (2008, p.14-15), ao abordar a tipologia da informação, argumenta com base em Moresi (2000) a classificação da informação quanto à sua aplicabilidade nos níveis organizacionais.

- Informação de nível institucional: permite ao nível institucional observar as variáveis presentes nos ambientes externo e interno, com a finalidade de monitorar e avaliar o desempenho e subsidiar o planejamento e as decisões de alto nível.

- Informação de nível intermediário: permite ao nível intermediário observar variáveis presentes nos ambientes externo e interno, monitorar e avaliar seus processos, o planejamento e a tomada de decisão de nível gerencial. 
- Informação de nível operacional: possibilita ao nível operacional executar suas atividades e tarefas, monitorar o espaço geográfico sob sua responsabilidade e subsidiar o planejamento e a tomada de decisão de nível operacional.

Pela afirmação da autora, nota-se que a informação está presente em todos os níveis organizacionais, cabendo a cada um utilizá-la de modo que melhor contribua para o desenvolvimento de seus processos, bem como para o desenvolvimento dos processos organizacionais de forma geral, visto que a organização é estabelecida por um conjunto de interações e interligações que visam atender à missão e aos objetivos finais da organização.

Beal (2008, p.15) aborda, ainda, que a informação pode ser vista sob o ponto de sua aplicabilidade. A autora, apoiando-se em Lesca \& Almeida (1994), cita as seguintes categorias referentes à aplicação da informação nas organizações.

- Informação de atividade: aquela que permite à organização garantir seu funcionamento. Pedidos de compra, nota de saída de material, custo de implementação de um projeto são exemplos de informação de atividade. Esse tipo de informação costuma ser bastante estruturado e normalmente diz respeito ao nível operacional das organizações.

- Informação de convívio: aquela que possibilita aos indivíduos se relacionarem e pode influenciar seus comportamentos. São exemplos desse tipo de informação: jornal interno, reunião de serviço, ação publicitária. A informação de convívio é, na maioria das vezes, estruturada, estando presente em todos os níveis hierárquicos.

- Informação estratégica: aquela capaz de melhorar o processo decisório em função da sua capacidade de reduzir o grau de incerteza em relação às variáveis que afetam a escolha das melhores alternativas para superação de desafios e o alcance dos objetivos organizacionais.

Pelo exposto, cabe definir as expressões informação estruturada e informação não estruturada. A informação estruturada é aquela que está relacionada a um padrão estabelecido, já a informação não estruturada não se relaciona a nenhum padrão estabelecido. 
Ressalta-se que a informação somente terá real efetividade junto ao desenvolvimento da organização, a partir do momento que os indivíduos perceberem que ela é de fato um insumo para tal desenvolvimento. Isso ocorrerá a partir do momento que o compartilhamento da informação seja visto como um processo natural no âmbito das atividades e tarefas realizadas na organização, e a cultura informacional da organização atue de forma positiva em relação a esse compartilhamento.

[Definimos] o compartilhamento de informações como o ato voluntário de colocá-las à disposição de outros, ressaltando que compartilhar não deve ser confundido com relatar, que é uma troca involuntária de informações de maneira estruturada e rotineira (Davenport \& Prusak, 1998, p.115)

O compartilhamento de informações na organização, portanto, tem que partir dos próprios indivíduos, e não por meio de algum tipo de imposição da alta administração, isto é, os indivíduos têm que tomar consciência da importância da informação e do conhecimento para a organização, assim como necessitam perceber que compartilhar informação e conhecimento será proveitoso e resultará em bons resultados, tanto para a própria organização quanto para ele próprio como colaborador direto.

Desse modo, entende-se que, no contexto organizacional, as organizações devam saber usufruir da informação e do conhecimento, de modo a melhorar sua competitividade junto ao mercado, bem como ao desenvolvimento de seus processos, produtos e serviços. Ressalte-se que existem processos como a gestão da informação, a gestão do conhecimento e a inteligência competitiva, que podem contribuir para a melhor utilização desses insumos no contexto organizacional. Pelo exposto, cabe breve conceituação desses processos.

Gestão da informação visa "trabalhar" a informação por meio de ações direcionadas desde a busca até o uso, atuando diretamente com os fluxos formais gerados internamente e externamente à organização. Segundo Dias \& Belluzzo (2003, p.47), "a gestão da informação 
é o conjunto de conceitos, princípios, métodos e técnicas utilizados na prática administrativa colocados em execução pela liderança de um serviço de informação em C\&T para atingir a missão e os objetivos fixados".

Segundo Tarapanoff (2006, p.22), ela tem como principal objetivo identificar e potencializar os recursos informacionais de uma organização, de forma a propiciar-lhe maior capacidade de se adaptar às mudanças ambientais. Sob o argumento da referida autora, consiste em um processo contínuo composto de seis etapas distintas e inter-relacionadas. "Comporta a identificação de necessidades informacionais; sua aquisição; armazenagem; desenvolvimento de produtos e serviços; distribuição e uso efetivos" (Tarapanoff, 2001, p.312).

Gestão do conhecimento relaciona-se ao meio pelo qual são trabalhados os fluxos informais da organização de modo a extrair deles novos conhecimentos, ou seja, a gestão do conhecimento visa trabalhar o capital intelectual das organizações. "A gestão do conhecimento é um processo estratégico contínuo e dinâmico que visa gerir o capital intangível da empresa e todos os pontos estratégicos a ele relacionados e estimular a conversão do conhecimento" (Rossato, 2002, p.7).

O processo de inteligência competitiva organizacional relaciona-se a uma investigação e um diagnóstico contínuos, tanto do ambiente interno quanto do externo, encontrando e retirando desses informações úteis à tomada de decisão da organização, visando ao estabelecimento de estratégias de ação de curto, médio e longo prazos (Valentim et al., 2003, p.1). Assim, tal processo auxilia no melhor aproveitamento das informações e conhecimentos por parte da organização, com o fim de auxiliar nos processos de tomada de decisão da mesma. De acordo com Miller (2002, p.52), o "processo de inteligência competitiva se inicia de uma necessidade que a organização detecta ao se deparar com problemas complexos e relacionados à falta de informação, relativa tanto ao ambiente interno como o externo".

Desse modo, entende-se que no contexto organizacional as organizações devam saber usufruir da informação e do conhecimento 
de modo a melhorar sua competitividade junto ao mercado, bem como para o desenvolvimento de seus processos, produtos e serviços. Entretanto, é necessário que os indivíduos possuam um comportamento informacional proativo nesse contexto.

\section{Comportamento informacional em organizações}

No que tange-as pessoas, Robbins (2005, p.18) destaca que "os funcionários de uma empresa podem ser os principais estimuladores da inovação e da mudança, ou podem ser seu principal bloqueio", o que nos direciona ao entendimento de que, sendo os indivíduos o "alicerce" da organização, logo qualquer comportamento que eles desenvolverem dentro da organização pode influir direta ou indiretamente no desenvolvimento da organização.

Beal (2008, p.45) aborda que "a forma como os usuários lidam com a informação (buscam, usam, alteram, trocam, acumulam, ignoram) afeta profundamente a qualidade do fluxo informacional nas organizações". Desse modo, é de extrema importância que seja dada atenção ao comportamento informacional dos indivíduos de uma organização.

Nesse sentido, o comportamento informacional está ligado a todas as atitudes e comportamentos que um indivíduo possui em relação à informação. Denota-se que o comportamento informacional abarca comumente o contexto das necessidades, busca e uso da informação. Davenport \& Prusak (1998, p.110) e Spink \& Cole (2006, p. 25 apud Cavalcante \& Valentim, 2008, p.120) argumentam que o comportamento informacional está ligado a todas as atitudes em relação à informação, sua busca, recuperação, filtragem, uso e disseminação. Woida \&Valentim (2008, p.95-96) argumentam que o comportamento informacional está relacionado à cultura informacional existente na organização:

o comportamento informacional é resultado da incorporação e da prática de elementos da cultura informacional existentes na organização que 
valoriza a informação, bem como propicia que esse valor seja transformado em ações de busca, captura, aquisição, compartilhamento e uso para a tomada de decisão.

Por essa afirmação, compreende-se que o comportamento informacional é algo intrínseco a cada organização; no entanto, por vezes, os gestores não dispõem atenção adequada a essa questão, uma vez que a informação como fator estratégico ao desenvolvimento organizacional nem sempre é vista dessa maneira, e muitas vezes é denegada.

Antes de prosseguirmos, cabe breve exploração no que tange às necessidades, busca e uso da informação. Nesse sentido, as necessidades de informação são, segundo Calva González (2004, p.68), “a carência que um indivíduo tem de conhecimentos e informação causados por fatores externos e internos que provocam um estado de insatisfação" nesse indivíduo. De acordo com essa autora, as necessidades de informação surgem por inquietações, tanto internas quanto externas ao usuário, revelando que essas necessidades podem surgir da relação do indivíduo com o meio.

Com relação ao comportamento de busca da informação, Spink \& Cole (2006, p.25) o definem "como um subconjunto do comportamento informacional que inclui a busca intencional de informação em relação a um objetivo". Ressalta-se na busca da informação que o indivíduo pode relacionar-se com os sistemas de informação. O comportamento de uso da informação está relacionado a satisfazer uma determinada necessidade de informação, conforme ressalta Le Coadic (2004, apud Chagas, 2006, p.30) ao afirmar que "usar a informação é trabalhar com a matéria informação para obter um efeito que satisfaça a necessidade de informação”.

O uso da informação envolve a seleção e o processamento da informação, de modo a responder a uma pergunta, resolver um problema, tomar uma decisão, negociar uma posição ou entender uma situação; logo, no contexto organizacional, usar a informação está relacionado aos processos de tomada de decisão da organização. De acordo com Souza (2004, p.24) o "uso da informação para a tomada 
de decisão nas organizações é parte fundamental no que se refere às suas atividades internas, também é elemento essencial nos mecanismos que regulam a relação entre empresa e seu meio ambiente".

Ressalte-se que, no contexto organizacional, o comportamento informacional dos indivíduos está sob constante influência da cultura organizacional e informacional desse contexto. Nesse sentido, a cultura organizacional centra-se em crenças e visões compartilhadas que podem delinear comportamentos e atitudes no ambiente organizacional. Schein (2001, p.29-36) argumenta que a cultura é um elemento que serve tanto para adaptação de um determinado grupo a um determinado ambiente quanto para integrar e fazer que tal grupo a adote como a forma correta de pensar e agir, ou seja, ela permeia toda a organização e é a responsável pelo modo como as pessoas agem no ambiente organizacional, influenciando seus comportamentos e atitudes.

Em uma esfera mais micro, tem-se a cultura informacional que também está pautada por crenças e visões relacionadas ao modo como os indivíduos lidam com a informação nesse contexto. Para Woida \& Valentim (2006, p.40), a cultura informacional compreende um "conjunto de pressupostos básicos compostos de princípios, valores, crenças, ritos e comportamentos positivos em relação à construção, socialização, compartilhamento e uso de dados, informação e conhecimento no âmbito corporativo". Davenport \& Prusak (1998, p.110) enunciam a cultura informacional como um padrão de comportamento em relação à informação, o que implica diretamente o modo como a informação é "trabalhada" pelos membros da organização, ou seja, a cultura informacional é o reflexo do modo como os membros da organização buscam, utilizam e disseminam a informação no contexto organizacional.

Desse modo, ambas delineiam comportamentos e atitudes; no entanto, com enfoques distintos; portanto, no contexto organizacional o comportamento dos indivíduos está sujeito à influência de tais culturas.

Ao passo que o contexto organizacional é permeado por intensos fluxos informacionais, e a informação é um fator que pode auxiliar 
o desenvolvimento das organizações, é necessário que o indivíduo possua comportamentos proativos em relação à informação, uma vez que é por meio desse que, direta ou indiretamente, perpassam todos os processos organizacionais e, por consequência, as informações também. Nesse sentido, existe uma necessidade de os gestores compreenderem a relevância do comportamento informacional junto ao desenvolvimento de processos e tarefas organizacionais, bem como a necessidade de compreensão acerca do que engloba o comportamento informacional.

\section{Considerações finais}

Pelo exposto, foi possível compreender o ambiente organizacional, bem como alguns dos elementos que o englobam, e também compreender a importância da informação e do conhecimento nesse contexto como insumos estratégicos ao desenvolvimento organizacional. Compreende-se que o comportamento informacional dos indivíduos é de extrema importância às organizações, uma vez que é por tal comportamento que a informação é trabalhada nesse contexto.

Nesse sentido, os gestores devem devotar maior atenção a tal comportamento, bem como compreender a sua importância junto aos processos e serviços organizacionais, o que possibilita direcionar uma gestão de pessoas com enfoque em tal comportamento.

O contexto organizacional se constitui, portanto, em um espaço informacional que propicia o desenvolvimento de estudos voltados à informação e ao conhecimento, bem como ao modo como os indivíduos lidam com tais elementos nesse contexto.

\section{Referências}

ALMEIDA JÚNIOR, O. de. Mediação da Informação: ampliando o conceito de disseminação. In:VALENTIM, M. L. P. (Org.) Gestão 
da informação e do conhecimento no âmbito da Ciência da Informação. São Paulo: Polis; Cultura Acadêmica, 2008.

BEAL, A. Gestão estratégica da informação: como transformar a informação e a tecnologia da informação em fatores de crescimento e de alto desempenho nas organizações. São Paulo: Atlas, 2004.

BELUZZO, R. C. B.; FERES, G. G. A mediação da informação para o setor produtivo como recurso estratégico na sociedade do conhecimento. In: SIMPÓSIO DE ENGENHARIA DE PRODUÇÃO (Simpep), 10, 2003, Bauru. Anais... Bauru, 2003.

BUKOWITZ, W. R.; WILLIAMS, R. L. Manual de gestão do conhecimento: ferramentas e técnicas que criam valor para a empresa. Porto Alegre: Bookman, 2002.

CALVA GONZÁLEZ, J. J. Las necesidades de información: fundamentos teóricos y métodos. México: Unam/Cuib, 2004.

CAVALCANTE, L. de F. B; VALENTIM, M. L. P. Comportamento informacional em ambientes empresariais e o processo de inteligência competitiva organizacional. In: VALENTIM, M. L. P. (Org.) Gestão da informação e gestão do conhecimento no âmbito da Ciência da Informação. São Paulo: Polis; Cultura Acadêmica, 2008. p.117-27.

CHAGAS, L. D. Efetividade do processo de comunicação com base na teoria do comportamento informacional: o caso de um organismo internacional da área da saúde pública sediado no Brasil. Brasília, 2006. 152f. Dissertação (Mestrado) - Programa de Pós-Graduação em Ciência da Informação, Universidade de Brasília.

CHIAVENATO, I. Introdução à Teoria Geral da Administração: uma visão abrangente da moderna administração das organizações. Rio de Janeiro: Elsevier, 2003. 630p.

CHOO, C. W. A organização do conhecimento: como as organizações usam a informação para criar significado, construir conhecimento e tomar decisões. São Paulo: Senac Editora, 2003. 425p.

DAVENPORT, T.; PRUSAK, L. Ecologia da informação: por que só a tecnologia não basta para o sucesso na era da informação. São Paulo: Futura, 1998.316p.

Conhecimento empresarial: como as organizações gerenciam o seu capital intelectual. 11.ed. Rio de Janeiro: Elsevier, 2001. 237p.

DAVIS, J. et al. Generation to generation: Life cycle of family business. S. 1.: HBS Press Book, 1997. 
DAVIS, K.; NEWSTROM, J.W. Comportamento humano no trabalho. São Paulo: Pioneira, 1992.

DIAS, M. M. K.; BELLUZZO, R. C. B. Gestão da informação em ciência e tecnologia sob a óptica do cliente. Bauru: Edusc, 2003.

LE COADIC, Y. A Ciência da Informação. 2.ed. Brasília: Briquet de Lemos, 2004.

MORESI, E. A. D. Delineando o valor do sistema de informação de uma organização. Ciência da Informação, Brasília, v.29, n.1, jan./ abr. 2000.

NONAKA, I.; TAKEUCHI, H. Criação do conhecimento na empresa: como as empresas japonesas geram a dinâmica da inovação. 5.ed. Rio de Janeiro: Campus, 1997. 358p.

OLIVEIRA, D. de P. R. de. Estrutura organizacional. In: Sistemas, organizações $\mathcal{E}$ métodos: uma abordagem gerencial. 12.ed. São Paulo: Atlas, 2001. 497p.

REZENDE, D. A.; ABREU, A. F. Tecnologia da informação aplicada a sistemas de informação empresariais. São Paulo: Atlas, 2003.

SCHEIN, E. H. Guia de sobrevivência da cultura corporativa. Rio de Janeiro: José Olympio, 2001. 191p.

SOUZA, C. A. de. Uso organizacional da tecnologia de informação: um estudo sobre a avaliação do grau de informatização de empresas e indústrias paulistas. São Paulo, 2004 . 309f. Tese (Doutorado) - Faculdade de Economia Administração e Contabilidade, Universidade de São Paulo.

TARAPANOFF, K. Inteligência organizacional e competitiva. Brasília: UnB, 2001.

Informação, conhecimento e inteligência em corporações: relações e complementaridade. In: (Org.) Inteligência, informação e conhecimento. Brasília: IBICT; Unesco, 2006. p.19-35.

VALENTIM, M. L. P. Processo de inteligência competitiva organizacional. In: . (Org.) Informação, conhecimento e inteligência organizacional. Marília: Fundepe Editora, 2006. p.9-24.

VALENTIL, M. L. P. et al. O processo de inteligência competitiva em organizações. DataGramaZero, Rio de Janeiro, v.4, n.3, p.1-23, jun. 2003. Disponível em: <http://www.dgz.org.br/jun03/ Art_03.htm>. Acesso em: 3 jul. 2008.

. Gestão da informação e gestão do conhecimento no âmbito da Ciência da Informação. São Paulo: Polis; Cultura Acadêmica, 2008. 
VALENTIL, M. L. P.; GELINSKI, J. V. V. Gestão do conhecimento corporativo. In: VALENTIM, M. L. P. (Org.) Informação, conhecimento e inteligência organizacional. Marília: Fundepe Editora, 2006. p.115-32.

WILSON, T. D. Human information behavior. Informing Science Research, Colorado, v.3, n.2, 2000.

WOIDA, L. M.; VALENTIM, M. L. P. Cultura organizacional/cultura informacional: a base do processo de inteligência competitiva organizacional. In: VALENTIM, M. L. P. (Org.) Informação, conhecimento e inteligência organizacional. Marília: Fundepe Editora, 2006. p.25-44.

Cultura informacional: um modelo de realidade social para a ICO. In:VALENTIM, M. L. P. (Org.) Gestão da informação e gestão do conhecimento no âmbito da Ciência da Informação. São Paulo: Polis; Cultura Acadêmica, 2008. p.117-27. 


\title{
12 \\ COMPETÊNCIA EM INFORMAÇÃO E SUA AVALIAÇÃO
}

\author{
André Luís Onório Coneglian \\ Camila Araújo dos Santos \\ Helen de Castro Silva Casarin
}

\section{Introdução}

Atualmente, o universo informacional apresenta-se de forma conflitante para os indivíduos, o que torna necessário dominar habilidades, atitudes, valores e conhecimentos em relação aos diversos recursos informacionais, ações denominadas de competência em informação.

Neste capítulo, discutiremos o conceito e as diferentes traduções da Information Literacy e a avaliação de estudantes e programas no que diz respeito às competências em informação.

Pretendemos contribuir para o avanço do tema, mais que discutir sobre as diversas traduções ou expressões que representam o conceito de competência em informação. Além disso, refletir sobre as possibilidades de implantação nos vários níveis educacionais, mas, e especialmente, revisar as diversas formas de avaliação dos programas de competência em informação. 


\section{Competência em informação ou competência informacional?}

Desde o surgimento da expressão Information Literacy na década de 1970, nos Estados Unidos, muito já se discutiu sobre as traduções e adequações do termo como Alfabetización Informacional, na Espanha e América Latina, Literacia, em Portugal, Competência Informacional ou Letramento Informacional, no Brasil (Dudziak, 2001; Campello, 2009).

Sabemos que cada termo - literacy, alfabetización, competência e letramento - possui etimologias diferentes, porém entendemos que todas se referem à mesma essência, conceito e processo, ainda que Bruce (2003) tenha compilado sete abordagens diferentes para Information Literacy, a saber: 1) tecnologias da informação; 2) fontes de informação; 3 ) informação como processo; 4) controle da informação; 5) construção do conhecimento; 6) extensão do conhecimento e 7) saber.

Pretendemos avançar na discussão sobre as traduções e adequações do termo Information Literacy, trazendo para debate o neologismo "informacional”, derivação de "em informação", conforme proposto por Belluzzo (informação verbal), ${ }^{1}$ mas é salutar a reflexão que propomos a seguir para justificar o uso de Competência em informação e não Letramento em informação, por exemplo.

Sabemos que as palavras alfabetização e letramento estão intrinsecamente relacionadas aos processos e fazeres pedagógicos, aos primeiros anos de escolarização, sendo a primeira entendida como o ato de ensinar a ler e escrever (o alfabeto) e a segunda, condição daquele indivíduo ou grupo que faz uso social competente da leitura e da escrita.

1 Informação fornecida por Regina Célia Baptista Belluzzo na "I Reunião de Linha de Pesquisa Gestão, Mediação e Uso da Informação”, do Programa de PósGraduação em Ciência da Informação da Universidade Estadual Paulista (Unesp), campus de Marília, 2009. 
Sobre essa distinção, vejamos a importante contribuição de Soares (2002, p.36):

Há, assim, uma diferença entre saber ler e escrever, ser alfabetizado, e viver na condição ou estado de quem sabe ler e escrever, ser letrado (atribuindo a essa palavra o sentido que tem literate em inglês). Ou seja, a pessoa que aprende a ler e a escrever - que se torna alfabetizada - e que passa a fazer uso da leitura e da escrita, a envolver-se nas práticas sociais de leitura e de escrita - que se torna letrada - é diferente de uma pessoa que não sabe ler e escrever - é analfabeta - ou, sabendo ler e escrever, não faz uso da leitura e da escrita - é alfabetizada, mas não é letrada, não vive no estado ou condição de quem sabe ler e escrever e pratica a leitura e a escrita.

Desse modo, usar competência e não alfabetização (alfabetización), nem letramento (tradução direta do termo literacy, em inglês), em conjunto com o adjetivo - ou neologismo informacional ou ainda na sua forma como locução adjetiva - em informação, facilita o entendimento da Information Literacy, não atrelado à essência de alfabetização e de letramento na concepção educacional, somados ao adjetivo "informacional" ou "em informação".

Não podemos reduzir o entendimento de competência como sinônimo de habilidade ou capacidade na concepção inata, ou seja, habilidades e capacidades inerentes desde o nascimento, como aprendidas e adquiridas ao longo da vida, formalmente na escola, com planejamento e ações direcionadas e mediadas por indivíduos já competentes. É válido enfatizar que o termo “competência” não está relacionado com o conceito de "competitividade", mas, sim, à habilidade de alguém utilizar seu conhecimento para alcançar um propósito. Competência é a capacidade para usar habilidades, conhecimentos, atitudes e experiência adquirida para desempenhar bem os papéis sociais (Deffune \& Depresbiteris, 2000, p.50). As habilidades são atributos relacionados não apenas ao saber-fazer, mas aos saberes (conhecimentos), ao saber-ser (atitudes) e ao saber-agir (práticas no mercado de trabalho e trabalhos acadêmicos). 
Campello (2009, p.7) diz que o conceito de letramento informacional surgiu como sustentação de uma prática educativa para ajudar as pessoas a "desenvolver habilidades de usar informações, tornando-as capazes de aprender de forma autônoma e ao longo da vida".

Soares (2002, p.38), ao definir a palavra letramento, usa a seguinte apresentação:

Quadro 1 - Letramento

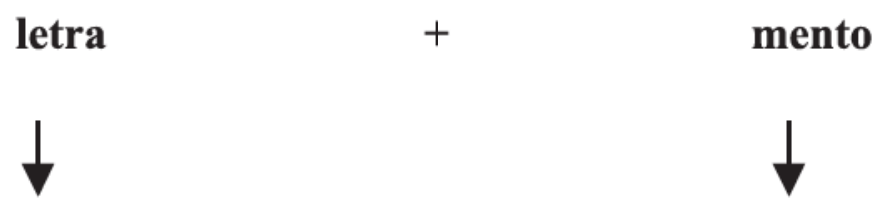

Forma portuguesa

da palavra latina littera sufixo, indica resultado de

uma ação. Ex.: ferimento,

resultado da ação de ferir.

Fonte: Soares (2002, p.38)

Letramento, portanto, para Soares (2002, p.39), é o "resultado da ação de ensinar e aprender as práticas sociais da leitura e escrita; o estado ou condição que adquire um grupo social ou um indivíduo como consequência de ter-se apropriado da escrita e de suas práticas sociais".

Letramento informacional, para Campello(2009, p.9), é "tornar pessoas capazes de aprender a partir de informações”, e ainda

uma capacidade essencial, necessária aos cidadãos para se adaptar à cultura digital, à globalização e à emergente sociedade baseada no conhecimento. Implicaria fundamentalmente que as pessoas tivessem capacidade de entender suas necessidades de informação e de localizar, selecionar e interpretar informações, utilizando-as de forma crítica e responsável. (ibidem, p.12-13) 
Vemos que no conceito de letramento a essência está sobre o aprender e usar com eficiência a leitura e a escrita. Já em letramento informacional, é recorrente o emprego de palavras como capazes, capacidade, relacionadas à localização, seleção e interpretação de informações. Interpretar informações está intrinsecamente relacionado à habilidade de ler e escrever para um fim, como adquirir e produzir novos conhecimentos, ou seja, competências para saber como funciona uma biblioteca, quais tipos de acervos, gêneros textuais e/ou suportes informacionais, como estão organizados e como utilizá-los.

Entendemos que é um processo - competências, habilidades, capacidades - a ser ensinado, preferencialmente de modo consciente, crítico, reflexivo, e não apenas resultado de uma ação, letrar-se ou ser letrado em informação.

Todos os indivíduos podem tornar-se competentes em informação. A competência em informação é um pré-requisito para a aprendizagem contínua, e é comum a todos os ambientes de aprendizagem e a todos os níveis educacionais. As habilidades propostas pela competência em informação devem iniciar nos primeiros anos de escola e se prolongar por toda a vida, em crescentes níveis de autonomia, levando ao aprender a aprender.

As diretrizes da International Federation of Library Associations and Institutions (2006), por exemplo, podem ser aplicadas em qualquer tipo de biblioteca, com pequenas adaptações, como também servem para variados públicos, seja para "comunicação interpessoal cotidiana de qualquer cidadão, desde uma pessoa que precisa de informação sobre serviços de saúde para alguém a seus cuidados até um estudante que busca encontrar informação específica para completar uma atividade". Essa diretriz pode ser adaptada a qualquer tipo de público, entendendo-se, assim, que crianças, jovens, adultos e idosos podem tornar-se competentes em informação, seja no âmbito escolar, profissional e pessoal.

Cabe ressaltar que competência em informação não é apenas uma questão de possuir habilidades, mas, sobretudo, uma maneira de aprender: "a busca de informação é um processo de construção que 
envolve a experiência de vida, os sentimentos, bem como os pensamentos e as atitudes de uma pessoa" (Kuhlthau, 1991, p.362). Entretanto, segundo Kuhlthau, a pesquisa de informação não é um ato intuitivo. Para que os estudantes obtenham sucesso, devem receber instrução e suporte durante o processo de pesquisa.

Habilidades, atitudes, valores e conhecimentos da competência em informação podem ser representados pelas seguintes questões desenvolvidas por Marland (apud Campello, 2009, p.16-17):

- O que preciso fazer? (formulação e análise de necessidades)

- Aonde posso ir? (identificação e avaliação de recursos adequados)

- Onde consigo a informação? (localização individual de recursos)

- Que recursos devo usar? (exame, seleção e rejeição de recursos)

- Como devo usar os recursos? (interrogação dos recursos)

- O que devo registrar? (registro e armazenamento de informação)

- Tenho a informação de que preciso? (interpretação, análise, síntese, avaliação)

- Como devo fazer a apresentação? (apresentação, comunicação)

- O que obtive? (avaliação).

Os indivíduos podem desenvolver habilidades relativas ao manuseio dos diversos recursos informacionais, conhecimentos sobre as diversas fontes de informações existentes, valores que permitem que o indivíduo reconheça suas necessidades informacionais e saibam acessar, avaliar e apropriar as informações recuperadas e atitudes para pensar criticamente diante do universo informacional.

As competências em informação devem ser desenvolvidas ao longo da vida, por intermédio de atividades estruturadas por professores e bibliotecários:

Busca-se o desenvolvimento de oportunidades de aprendizagem inovadora, integrando as competências de ambos, representadas pelo domínio do conteúdo (por parte do professor) e de habilidades informacionais (por parte do bibliotecário), em sequência lógica que beneficie a aprendizagem. (Campello, 2009, p.56-7) 
A competência em informação deve ser vista como um aspecto relevante no contexto social, já que

Ela está calcada em duas dimensões distintas: a primeira, um domínio de saberes e de habilidades de diversas naturezas, que permite a intervenção prática na realidade, e a segunda, uma visão crítica do alcance das ações e o compromisso com as necessidades mais concretas que emergem e caracterizam o contexto social. (Belluzzo, 2006, p.82)

É por meio do desenvolvimento de competências em informação que o indivíduo pode apropriar-se das informações correspondentes às suas necessidades informacionais de forma mais proveitosa. Dessa forma, destacamos o papel social que a competência em informação exerce na sociedade: o indivíduo competente em informação participa ativamente da construção de conhecimento e da sociedade, como sujeito que reflete e que tem uma visão crítica diante de um universo informacional denso e com informações conflitantes.

A competência em informação mostra os "caminhos que devem ser trilhados" por um indivíduo no processo de busca, recuperação, avaliação e apropriação de informações, uma vez que trabalha habilidades, atitudes, conhecimentos e valores que devem ser incorporados nesse processo. Para isso, a avaliação do nível de competências em informação é um elemento importante para verificar se os indivíduos incorporaram as habilidades relacionadas a esse processo.

\section{Avaliando competência em informação}

Ante o exposto, é evidente a necessidade do desenvolvimento e implantação de programas voltados para a competência em informação, desde as primeiras séries do Ensino Fundamental - quiçá na Educação Infantil - continuando na Educação Superior.

O livro de Carol Kuhlthau (2002, p.10) Como usar a biblioteca na escola: um programa de atividades para o ensino fundamental, por 
exemplo, cujo objetivo é "auxiliar os educadores na complexa tarefa de desenvolver nos alunos, de maneira sistemática, habilidades para lidar com a informação", apresenta um programa de atividades com objetivos definidos, sugestões de materiais, instruções e como o professor deve aplicá-los.

Pergunta-se: como avaliar tais atividades? Com base nos objetivos, entende-se que, ao final da atividade e em outras subsequentes, se os alunos atingirem os objetivos propostos no início, terão obtido sucesso. Desse modo, não apenas professores, que historicamente têm a responsabilidade de "mensurar" o quanto seus alunos aprenderam, mas também bibliotecários têm a responsabilidade de avaliar a aprendizagem, quando responsável pela aplicação de tais programas. Desse modo, professores e bibliotecários devem trabalhar em conjunto no planejamento e execução desses programas, ambos devem participar do processo de avaliação.

Um aspecto importante desse processo, porém, não é necessariamente de quem é a responsabilidade de avaliar, mas, sim, a forma de avaliação.

Conforme exposto anteriormente, os princípios e habilidades relacionados ao manejo de informações não são inatos, desse modo não se pode reduzir a avaliação da competência em informação à classificação daqueles que têm e aqueles que não têm tais princípios e habilidades. Todos precisam desenvolvê-las, porém cada um aprende num ritmo e de modos diferentes. Deve-se considerar e respeitar a idiossincrasia, as especificidades e as várias formas e manifestações de inteligências (Gardner, 1995; Antunes, 2003). Os profissionais envolvidos nas atividades devem ter a consciência de que a aprendizagem difere de pessoa para pessoa. Os indivíduos e os grupos têm, por princípio, diferentes competências e, provavelmente, motivações variadas em relação ao desenvolvimento de competências.

Assim, a discussão sobre a avaliação deve pautar-se pelos modelos de avaliação, diferenciando, por exemplo, avaliação formativa de avaliação normativa. Campello (2009, p.64) cita Frederick Lancaster para referenciar a avaliação de serviços de bibliotecas: 
O autor apontou inicialmente que, na avaliação de um programa de instrução bibliográfica - que hoje corresponderia a um programa de desenvolvimento de habilidades informacionais ou de letramento informacional-, pode-se verificar, por exemplo, se os alunos usam os serviços da biblioteca de modo mais eficaz ou se obtêm bom desempenho em exercícios que envolvem o uso de fontes de informação. Mas, em última análise, o critério definitivo seria a melhoria dos trabalhos escolares dos estudantes. Assim, na avaliação da atividade, o importante é focalizar não a satisfação dos mediadores, mas o desempenho dos alunos.

Lancaster sistematizou o processo de avaliação da seguinte forma (Campello, 2009, p.65):

- Reação dos participantes: algo subjetivo, porém, pode ser coletado através de questionário.

- Conhecimentos adquiridos: o que os alunos aprenderam, relacionado às habilidades informacionais, mas também pode-se verificar se há uma atitude mais positiva sobre a biblioteca e a leitura, questão mais afetiva que cognitiva.

- Mudança comportamental: se usam mais a biblioteca, outras fontes de informação se obtêm êxito nos trabalhos escolares utilizando recursos informacionais.

- Resultados do programa: avaliação do programa como um todo, o que só é possível com a elaboração de objetivos antes de aplicar o programa.

Campello (2009) também cita o School Library Impact Measure (SLIM), para avaliar ações da biblioteca escolar desenvolvido por grupo de pesquisadores do Center for International Scholarship on School Libraries (CISSL), avaliação que consiste em levar o aluno a refletir no processo da pesquisa orientada ou pesquisa escolar, por exemplo:

- no início: conhecimentos prévios, interesse pelo tema;

- no meio: facilidades e dificuldades no processo;

- no fim: o que aprendeu. 
O SLIM, segundo Campello (2009, p.67):

Constitui um modelo de avaliação formativo, de abordagem cognitivista envolvendo operações mentais dos alunos e procura entender os diferentes processos que utilizam ao se apropriar dos conhecimentos centrando-se nos significados que atribuem a suas ações ao longo do percurso de aprendizagem.

Diferentemente de modelos de avaliação normativa, restritos a contabilizar erros e acertos; práticas tradicionais de avaliação como exames, provas de caráter certificativo, classificatório e punitivo. Deve-se considerar que a avaliação, quando relacionada ao ensino, deve ser uma

atividade sistemática e contínua, integrada ao processo educativo, que tem como objetivo proporcionar o maior número de informação para a melhoria desse processo, reajustando seus objetivos, revisando projetos e programas, métodos e recursos, e facilitando a máxima ajuda e orientação aos alunos. (Arenas, 2007, p.215)

Os parâmetros e indicadores do Information Power, elaborado pela American Association of School Librarians e Association for Educational Communications and Technology (1998), servem como subsídios para a criação de um instrumento de avaliação, não como elementos fixos de um checklist no qual se assinalam aqueles que se possuem e deixam em branco aqueles ainda não adquiridos.

No Information Power, para cada norma de competência em informação, existem indicadores que servem de suporte para o entendimento e aplicação das normas:

- Indicadores: definem as habilidades a serem desenvolvidas nos estudantes.

- Níveis de proficiência: indicadores que mostram em qual nível informacional se encontram os estudantes - básico, proficiente e exemplar.

- Padrões em ação: é uma situação de competência em informação. Um problema é apresentado aos estudantes e estes precisam bus- 
car as informações corretas em variadas fontes para solucionar a situação.

A título de exemplificação, utilizaremos os padrões e indicadores da categoria "Competência informacional", retirada de Campello (2009, p.23-24); para fins didáticos, colocamos em uma tabela com numeração, sendo 1 para a categoria Competência informacional, 1.1 a 1.3 para os padrões e 1.1.1 a 1.3.4 para os indicadores; 2 para a categoria Aprendizagem Independente, 2.1 a 2.3 para os padrões e 2.1.1 a 2.3.2 para os indicadores; e 3 para a categoria Responsabilidade Social, 3.1 a 3.3 para os padrões e 3.1.1 a 3.3.4 para os indicadores.

Quadro 2-Competência informacional

\begin{tabular}{|c|c|c|c|c|c|}
\hline 1 & $\begin{array}{l}\text { Competência } \\
\text { Informacional }\end{array}$ & 2 & $\begin{array}{l}\text { Aprendizagem } \\
\text { Independente }\end{array}$ & 3 & $\begin{array}{l}\text { Responsabilidade } \\
\text { Social }\end{array}$ \\
\hline 1.1 & $\begin{array}{l}\text { Acessa informação } \\
\text { de forma eficiente e } \\
\text { efetiva }\end{array}$ & 2.1 & $\begin{array}{l}\text { Procura informação } \\
\text { relacionada a } \\
\text { assuntos de } \\
\text { interesse pessoal }\end{array}$ & 3.1 & $\begin{array}{l}\text { Reconhece a } \\
\text { importância da } \\
\text { informação para } \\
\text { uma sociedade } \\
\text { democrática }\end{array}$ \\
\hline 1.1.1 & $\begin{array}{l}\text { Reconhece a } \\
\text { necessidade de } \\
\text { informação }\end{array}$ & 2.1.1 & $\begin{array}{l}\text { Busca informação } \\
\text { relacionada às } \\
\text { várias dimensões de } \\
\text { bem-estar, tais } \\
\text { como interesses } \\
\text { profissionais, } \\
\text { envolvimento } \\
\text { comunitário, } \\
\text { questões de saúde, } \\
\text { atividades de } \\
\text { recreação }\end{array}$ & 3.1 .1 & $\begin{array}{l}\text { Busca informação } \\
\text { de diversas fontes, } \\
\text { contextos, } \\
\text { disciplinas, } \\
\text { culturas }\end{array}$ \\
\hline 1.1 .2 & $\begin{array}{l}\text { Percebe que a } \\
\text { informação } \\
\text { apropriada e } \\
\text { abrangente é a base } \\
\text { para a tomada } \\
\text { inteligente de } \\
\text { decisões }\end{array}$ & 2.1.2 & $\begin{array}{l}\text { Projeta, desenvolve } \\
\text { e avalia produtos e } \\
\text { soluções de } \\
\text { informação } \\
\text { relacionados a } \\
\text { interesses pessoais }\end{array}$ & 3.1 .2 & $\begin{array}{l}\text { Respeita o } \\
\text { princípio de acesso } \\
\text { equitativo à } \\
\text { informação }\end{array}$ \\
\hline
\end{tabular}




\begin{tabular}{|c|c|c|c|c|c|}
\hline 1.1 .3 & $\begin{array}{l}\text { Formula perguntas } \\
\text { baseadas nas } \\
\text { necessidades de } \\
\text { informação }\end{array}$ & - & - & - & - \\
\hline 1.1 .4 & $\begin{array}{l}\text { Identifica uma } \\
\text { variedade de fontes } \\
\text { potenciais de } \\
\text { informação }\end{array}$ & - & - & - & - \\
\hline 1.1 .5 & $\begin{array}{l}\text { Desenvolve e usa } \\
\text { estratégias de } \\
\text { localização de } \\
\text { informação bem- } \\
\text {-sucedidas }\end{array}$ & - & - & - & - \\
\hline 1.2 & $\begin{array}{l}\text { Avalia informação } \\
\text { de forma crítica e } \\
\text { competente }\end{array}$ & 2.2 & $\begin{array}{l}\text { Aprecia literatura e } \\
\text { outras expressões } \\
\text { criativas de } \\
\text { informação }\end{array}$ & 3.2 & $\begin{array}{l}\text { Apresenta conduta } \\
\text { ética com respeito à } \\
\text { informação e às } \\
\text { tecnologias de } \\
\text { informação }\end{array}$ \\
\hline 1.2 .1 & $\begin{array}{l}\text { Determina } \\
\text { exatidão, relevância } \\
\text { e abrangência }\end{array}$ & 2.2 .1 & $\begin{array}{l}\text { É um aprendiz } \\
\text { competentee } \\
\text { automotivado }\end{array}$ & 3.2 .1 & $\begin{array}{l}\text { Respeita os } \\
\text { princípios de } \\
\text { liberdade } \\
\text { intelectual }\end{array}$ \\
\hline 1.2 .2 & $\begin{array}{l}\text { Distingue fato, } \\
\text { ponto de vista e } \\
\text { opinião }\end{array}$ & 2.2 .2 & $\begin{array}{l}\text { Deduz sentido de } \\
\text { informação } \\
\text { apresentada de } \\
\text { modo criativo e em } \\
\text { diferentes formatos }\end{array}$ & 3.2 .2 & $\begin{array}{l}\text { Respeita os direitos } \\
\text { de propriedade } \\
\text { intelectual }\end{array}$ \\
\hline 1.2 .3 & $\begin{array}{l}\text { Identifica } \\
\text { informação } \\
\text { imprecisa, inexata e } \\
\text { capciosa }\end{array}$ & 2.2 .3 & $\begin{array}{l}\text { Desenvolve } \\
\text { produtos criativos } \\
\text { em diferentes } \\
\text { formatos }\end{array}$ & 3.2 .3 & $\begin{array}{l}\text { Utiliza as } \\
\text { tecnologias de } \\
\text { informação de } \\
\text { forma responsável }\end{array}$ \\
\hline 1.2 .4 & $\begin{array}{l}\text { Seleciona } \\
\text { informação } \\
\text { apropriada para o } \\
\text { problema ou } \\
\text { pergunta propostos }\end{array}$ & - & - & - & - \\
\hline 1.3 & $\begin{array}{l}\text { Usa informação } \\
\text { corretamente e } \\
\text { produtivamente }\end{array}$ & 2.3 & $\begin{array}{l}\text { Empenha-se pela } \\
\text { excelência na busca } \\
\text { de informação e na } \\
\text { geração de } \\
\text { conhecimento }\end{array}$ & 3.3 & $\begin{array}{l}\text { Participa } \\
\text { efetivamente em } \\
\text { grupos de procura e } \\
\text { geração de } \\
\text { informação }\end{array}$ \\
\hline
\end{tabular}


GESTÃO, MEDIAÇÃO E USO DA INFORMAÇÃO 267

\begin{tabular}{|c|c|c|c|c|c|}
\hline 1.3.1 & $\begin{array}{l}\text { Organiza } \\
\text { informação para } \\
\text { aplicação prática }\end{array}$ & 2.3 .1 & $\begin{array}{l}\text { Avalia a qualidade } \\
\text { dos processose } \\
\text { produtos da busca } \\
\text { pessoal pela } \\
\text { informação }\end{array}$ & 3.3 .1 & $\begin{array}{l}\text { Compartilha } \\
\text { conhecimento e } \\
\text { informação com } \\
\text { os outros }\end{array}$ \\
\hline 1.3 .2 & $\begin{array}{l}\text { Integra nova } \\
\text { informação ao } \\
\text { conhecimento } \\
\text { próprio }\end{array}$ & 2.3.2 & $\begin{array}{l}\text { Delinea estratégias } \\
\text { para revisar, } \\
\text { melhorar e atualizar } \\
\text { o serviço ou o } \\
\text { conhecimento } \\
\text { gerado } \\
\text { individualmente }\end{array}$ & 3.3 .2 & $\begin{array}{l}\text { Respeita as ideias } \\
\text { e experiências } \\
\text { alheias e } \\
\text { reconhece suas } \\
\text { contribuições }\end{array}$ \\
\hline 1.3 .3 & $\begin{array}{l}\text { Aplica informação } \\
\text { ao pensamento } \\
\text { crítico e à resolução } \\
\text { de problemas }\end{array}$ & - & - & 3.3 .3 & $\begin{array}{l}\text { Colabora com os } \\
\text { outros na } \\
\text { identificação de } \\
\text { problemas de } \\
\text { informação e na } \\
\text { obtenção de suas } \\
\text { soluções, seja } \\
\text { pessoalmente ou } \\
\text { através das } \\
\text { tecnologias }\end{array}$ \\
\hline 1.3 .4 & $\begin{array}{l}\text { Produz e transmite } \\
\text { informação e ideias } \\
\text { em formatos } \\
\text { apropriados }\end{array}$ & - & - & 3.3 .4 & $\begin{array}{l}\text { Colabora com os } \\
\text { outros no projeto, } \\
\text { desenvolvimento } \\
\text { e avaliação de } \\
\text { produtos e } \\
\text { soluções de } \\
\text { informação, seja } \\
\text { pessoalmente ou } \\
\text { através das } \\
\text { tecnologias }\end{array}$ \\
\hline
\end{tabular}

Fonte: Campello (2009, p.23-4).

Cada padrão (1.1, 1.2 e 1.3) poderá funcionar como objetivos gerais, que comportariam atividades e estratégias para alcançar cada indicador. Vejamos: 
Quadro 3-Competência informacional em alunos do Ensino Fundamental

DESENVOLVENDO COMPETÊNCIA INFORMACIONAL EM ALUNOS DA $4^{a}$ SÉRIE DO ENSINO FUNDAMENTAL

- Para serem competentes em informação os alunos deverão:

Objetivos:

1) Acessar informação de forma eficiente e efetiva.

2) Avaliar informação de forma crítica e competente.

3) Usar informação corretamente e produtivamente.

Atividade: os alunos deverão se informar sobre os filmes que estão em cartaz nos cinemas da cidade; a turma deverá eleger um filme e sessão e se programar para ir ao cinema com o professor.

\section{Estratégias:}

Lançada a proposta da atividade para os alunos, o professor/mediador deverá:

a) Questioná-los onde conseguirão encontrar tais informações: se houver respostas como jornal, Internet, ligando aos cinemas, poderiam ser consideradas respostas pertinentes, desde que os alunos também tenham acesso a esses tipos de suportes e recursos. Ir até o local ou perguntar a terceiros poderiam ser consideradas respostas inadequadas diante do objetivo, ainda que consigam os horários e eleger um filme por meio dessas estratégias, não acessaram informação de forma eficiente, efetiva, autônoma.

b) Com os suportes e recursos em mãos, por exemplo, o jornal: questionar de que forma o jornal está estruturado; a informação sobre os filmes em cartaz poderá ser encontrada em que seção? Na Internet, seria mais fácil e mais rápido? O professor/mediador poderia montar grupos e cada grupo ficaria responsável por utilizar um recurso/suporte e apresentar para os colegas de turma, inclusive, já com os potenciais filmes que escolheriam, horários e valores.

c) Feita a eleição do filme, dia e horário, devem preparar-se para o dia: como iriam? Preparar mapas para aqueles que não conhecem o local escolhido; colher mais informações sobre o filme: informações técnicas ou sobre seu tema e conteúdo; após assistir, cada grupo poderia preparar um relatório sobre o processo desde o lançamento da proposta feita pelo professor/ mediador, contendo inclusive uma apreciação sobre a que assistiram, comparando com críticas lidas em jornais e revistas sobre o filme.

Avaliação: o professor/mediador deverá avaliar todo o processo e não apenas o resultado final, direcionando cada etapa da atividade. Poderia, ao término dessa atividade, propor outra parecida e verificar o grau de autonomia de cada aluno e/ou grupo para execução da nova atividade.

Fonte: Elaborada pelos autores. 
No Ensino Superior, a norma mais conhecida para o desenvolvimento de atividades e avaliação de competências em informação é a Literacy Competency Standards for Higher Education, desenvolvida pela Association of College and Research Libraries (ACRL) (2000). Essa norma tem a função de orientar no desenvolvimento e realização de programas de competência em informação e define os resultados que devem ser avaliados para demonstrar a aquisição da competência em informação dos estudantes do Ensino Superior (Neely \& Sullivan, 2006, p.17). Essa mesma entidade também criou diversas normas para grupos específicos de indivíduos, no que tange à avaliação de suas competências. ${ }^{2}$

Essa norma forma um conjunto de recomendações que explicitam as habilidades informacionais a serem desenvolvidas no ambiente escolar e universitário, como também demonstram as possibilidades de sua aplicação no âmbito dos conteúdos curriculares. Define também as funções da biblioteca e do profissional que nela atua.

A norma Literacy Competency Standards for Higher Education, desenvolvida pela Association of College and Research Libraries (ACRL) (2000), serve como uma espécie de manual para que bibliotecários e professores estruturem atividades relativas ao acesso, avaliação e apropriação das informações em diversas fontes informacionais, nas instituições de ensino que trabalham, como também mensuram as habilidades adquiridas pelos estudantes.

O objetivo da avaliação é verificar se os indivíduos adquiriram habilidades, atitudes e valores relacionados ao processo de busca e recuperação da informação e não o conhecimento adquirido. É mensurar se as habilidades foram apropriadas pelos indivíduos, e se de fato esses desenvolveram o senso crítico em relação ao universo informacional.

A avaliação é importante não só em curto ou médio prazo para verificar os conhecimentos adquiridos pelos alunos, mas também

2 Disponível em: <http://www.ala.org/ala/mgrps/divs/acrl/standards/ index.cfm>. Acesso em: 13 mar. 2010. 
em longo prazo, para determinar o comportamento e o rendimento acadêmicos dos estudantes. Assim, especificam-se os três tipos de avaliação da aprendizagem dos estudantes, segundo a International Federation of Library Associations and Institutions (IFLA) (2006):

- Prescritivo ou diagnóstico: avalia/testa o conhecimento e habilidade do participante antes da instrução. Podem tomar a forma de testes padronizados ou desenvolvidos pelo instrutor, audições ou revisões de trabalhos prévios do estudante, ou seja, procura traçar o nível de desempenho dos alunos.

- Formativo: fornece um feedback sobre a aprendizagem do aluno enquanto a instrução está em andamento e permite que o instrutor ajuste métodos de ensino durante o curso, ou seja, este pressupõe uma intervenção, e em seguida verifica-se até que ponto a instrução surta efeito.

- Somativo: é uma avaliação final dos critérios de avaliação que ocorre no fim da instrução, podendo ser questões de múltipla escolha, redações sobre condições controladas, uma avaliação de citações usada no trabalho de pesquisa do estudante ou em um portfólio de revisão.

Existem variados instrumentos que podem ser utilizados para mensurar a competência em informação de estudantes e de programas, dos quais podemos citar:

- Listas de verificação: são listas para guiar os estudantes na realização de sua avaliação. Elas incluem os diferentes estágios, níveis ou itens necessários para completar a avaliação. As listas de verificação (checklists) podem servir de lembretes para melhorar o crescimento do estudante, e ser fornecidas no começo da avaliação, assim poderiam ser usadas durante todo o processo de aprendizagem para autofeedback.

- Rubricas: é uma avaliação estruturada que guia os estudantes para alcançar um desempenho bem-sucedido. Isso normalmente inclui uma lista seriada dos atributos que o estudante deve desempenhar 
em suas tarefas de aprendizagem. A rubrica pode ser dividida segundo os passos do processo com indicação clara de cada elemento a ser considerado para alcançar o alvo desejado.

- Discussão: uma técnica que é baseada na discussão com o aprendiz ou entre a classe toda de forma oral. Isso pode ser feito nos diferentes estágios das tarefas, bem como no final do processo, usando questões levantadas pelo aplicador indagando sobre o processo de aprendizagem.

- Portfólios: consiste na acumulação do trabalho do estudante ao longo do tempo ejuntamente com os demais materiais gerados ao longo do processo de instrução de competências informacionais. $\mathrm{O}$ portfólio é um método de avaliação útil porque dá aos estudantes a possibilidade de ver o produto de sua aprendizagem tornar-se parte integrante de um produto final.

- Testes: é uma lista de questões com opções de respostas abertas e/ ou fechadas, na qual não foca o conteúdo do conhecimento. Pode ser usada quando o tempo é limitado ou quando a avaliação é especificamente focada em certos aspectos de aprendizagem.

Profissionais envolvidos com programas de competência em informação podem mensurar se as habilidades foram internalizadas pelos discentes no decorrer do processo. Esses instrumentos são direcionados para tal objetivo, uma vez que fornecem dados a respeito do andamento da aprendizagem dos indivíduos, ou seja, do processo como um todo e não de uma atividade isolada.

Esses instrumentos permitem que profissionais acompanhem a aprendizagem do aluno, bem como permite que o programa seja ajustado durante o desenvolvimento das atividades de competência em informação. Porém, é válido ressaltar que cabe a cada profissional utilizar o instrumento de acordo com a especificidade da pesquisa, da instituição que está conduzindo a avaliação ou ainda com os objetivos da mesma no tipo de avaliação.

Tal argumento é similar ao de Almeida Jr. (2003, p.104), segundo o qual a avaliação 
Inicia-se ou deve iniciar-se na própria formulação do projeto de serviço e caminhar com a implantação dele. Deve estar presente sempre, durante o período em que esse serviço existir. Deve também modificar, alterar, reestruturar os serviços, de acordo com os resultados.

Isso significa que a avaliação é importante na medida em que serve como um diagnóstico para verificar se o rendimento das atividades de competência em informação foi satisfatório ou não, tanto para os profissionais como para a instituição e os alunos.

No Brasil, percebe-se um crescimento nas pesquisas voltadas para a temática de avaliação da competência em informação, das quais podemos citar Mata (2009), Carranga (2008), Melo (2008) e Barbosa (2008). Tais estudos, de ordem exploratória, buscam mensurar por meio de questionários desenvolvidos e estruturados com base nos padrões da norma Literacy Competency Standards for Higher Education da Association of College and Research Libraries (2000) as competências dos estudantes do nível superior, por haver uma preocupação imensa com a formação de futuros profissionais e com sua atuação em um mercado de trabalho competitivo.

"Comportamento e competência informacionais" são o grupo de pesquisa coordenado pela Profa. Dra. Helen de Castro Silva, fruto do trabalho de pesquisas que vêm sendo desenvolvidas por docentes e discentes desde 2005, que têm por objetivo caracterizar o comportamento informacional de diferentes grupos de indivíduos; investigar os fatores que contribuem para que os indivíduos ou grupos de indivíduos apresentem determinado comportamento informacional; gerar subsídios para o trabalho do bibliotecário junto aos diferentes grupos de usuários visando ao aprimoramento dos serviços oferecidos.

No que tange à competência em informação, averiguar habilidades de busca, recuperação e uso da informação a partir de padrões internacionais; avaliar e desenvolver metodologias e programas para o desenvolvimento de habilidades para o acesso e uso da informação; e contribuir para que os indivíduos adquiram independência no uso e geração da informação. 


\section{Considerações finais}

A competência em informação permite que os indivíduos aprendam com a informação, para que analisem e avaliem as informações de forma crítica para a geração de conhecimento. Tais habilidades são fundamentais para as atividades acadêmicas, profissionais e pessoais na atualidade, pautadas pela produção e circulação exponenciais de informação e conhecimento, que são potencializados com a tecnologia.

O bibliotecário deve se preparar para lidar com as questões relacionadas à competência em informação que são muito próximas às de educação, pois incluem aprendizagem e avaliação aplicadas a diferentes níveis de formação. A avaliação tem a função diagnóstica, somativa e formativa, para apontar, acompanhar e possibilitar a apropriação de aspectos que devem ser trabalhados nos programas de competência e no aproveitamento do aluno, indicando a necessidade de ajustes e aperfeiçoamentos.

\section{Referências}

ALMEIDA JÚNIOR, O. F. de. Avaliação. In: Biblioteca pública: avaliação de serviços. Londrina: Eduel, 2003. p.101-72.

ANTUNES, C. As inteligências múltiplas e seus estímulos. Campinas: Papirus, 2003.

ARENAS, J. L. de. La evaluación de la alfabetización informacional: principios, metodologías y retos. Anales de Documentacion, n.10, p.215-32, 2007. Disponível em: <http://dialnet.unirioja.es/servlet/ articulo? codigo $=2340436>$. Acesso em: 2 nov. 2008.

ASSOCIATION OF COLLEGE AND RESEARCH LIBRARIES (ACRL). Information literacy: competency standards for higher education. 2000. Disponível em: <http://www.aab.es/pdfs/ baab60/60a6.pdf>. Acesso em: 22 jan. 2009.

AMERICAN ASSOCIATION OF SCHOOL LIBRARIANS/ ASSOCIATION FOR EDUCATIONAL COMMUNICATIONS AND TECHNOLOGY. Information power: building partnerships for learning. Chicago: ALA, 1998. 
BARBOSA, S. L. R. Avaliação de competências informacionais em formandos de arquivologia da UFBA. Salvador, 2008. 60f. TCC(Graduação em Arquivologia) - Instituto de Ciência da Informação, Universidade Federal da Bahia.

BELLUZZO, R. C. B. O uso de mapas conceituais e mentais como tecnologia de apoio à gestão da informação e da comunicação: uma área interdisciplinar da competência em informação. Revista Brasileira de Biblioteconomia e Documentação: Nova Série, São Paulo, v.2, n.2, p.78-89, dez. 2006.

BRUCE, C. Las siete caras de la alfabetización en información en la enseñanza superior. Anales de Documentación, n.6, p.289-94, 2003.

CAMPELLO, B. S. C. Letramento informacional. In: (Org.)

Letramento informacional: função educativa do bibliotecário na escola. Belo Horizonte: Autêntica, 2009. p.11-20.

Colaboração do bibliotecário com a equipe pedagógica. In: (Org.) Letramento informacional: função educativa do bibliotecário na escola. Belo Horizonte: Autêntica, 2009. p.53-62.

CARRANGA, G. A. Competência informacional no contexto acadêmico: um estudo com concluintes do curso de Biblioteconomia. Marília, 2008. 114f. TCC (Graduação em Biblioteconomia) - Faculdade de Filosofia e Ciências, Universidade Estadual Paulista "Júlio de Mesquita Filho".

DEFFUNE, D.; DEPRESBITERIS, L. Competências, habilidades e currículos de educação profissional: crônicas e reflexões. São Paulo: Senac Editora, 2000. 102p.

DUDZIAK, E. A. A information literacy e o papel educacional das bibliotecas. São Paulo, 2001. 187f. Dissertação (Mestrado) - Escola de Comunicação e Artes, Universidade de São Paulo.

GARDNER, H. Inteligências múltiplas: a teoria na prática. Porto Alegre: Artmed, 1995.

INTERNATIONAL FEDERATION OF LIBRARY ASSOCIATIONS AND INSTITUTIONS(IFLA). Guidelines on information literacy for lifelong learning. 2006. Disponível em: <http:/ /www.ifla.org/vii/s42/index.htm>. Acesso em: 17 nov. 2007.

KUHLTHAU, C. C. Inside the search process: information seeking from the user's perspective. Journal of the American Society for Information Science, v.42, n.5, 1991. 
Como usar a biblioteca na escola: um programa de atividades para o Ensino Fundamental. Belo Horizonte: Autêntica, 2002.303p. MATA, M. L. da. A competência informacional de graduandos de Biblioteconomia da Região Sudeste: um enfoque nos processos de busca e uso ético da informação. Marília, 2009. 162f. Dissertação (Mestrado) - Faculdade de Filosofia e Ciências, Universidade Estadual Paulista "Júlio de Mesquita Filho".

MELO, A. V. C. de. Análise do desenvolvimento dos estágios de competência informacional em estudantes do Curso de Graduação em Biblioteconomia da Universidade Federal da Paraíba - UFPB. João Pessoa, 2008. 451f. Dissertação (Mestrado) - Centro de Ciências Sociais Aplicadas, Universidade Federal da Paraíba.

NEELY, T. Y.; SULLIVAN, K. Integrating the ACRL Standards. In: Information literacy assessment: standards-based tools and assignments. Chicago: ALA, 2006. p.6-18.

SOARES, M. Letramento: um tema em três gêneros. 2.ed. Belo Horizonte: Autêntica, 2002. 



\title{
13 \\ GESTÃO DA INFORMAÇÃO E GOVERNANÇA CORPORATIVA EM EMPRESAS DE CAPITAL ABERTO
}

\author{
Elaine Cristina Lopes \\ Marta Lígia Pomim Valentim
}

\section{Introdução}

A realidade do mercado de capitais brasileiro ainda não se aproxima da realidade dos países mais desenvolvidos no que se refere à aceitação por parte do público poupador. Parte-se, então, da necessidade da geração de maior confiabilidade, sobretudo no que se refere ao acesso à informação confiável. Nesse contexto, surge a governança corporativa, que por suas características normatizadoras se constitui em um processo que, sobretudo, mediante a gestão da informação, busca reduzir a distância existente entre controladores da empresa e seus públicos de interesse.

A governança corporativa utiliza, especialmente, o conceito de transparência na prestação de informações, ou seja, a divulgação clara, consistente e confiável de atos e fatos relevantes relacionados à empresa. Entendem-se como atos ou fatos relevantes "todos os atos e fatos ocorridos nos negócios da companhia ou de suas controladas, inclusive decisões do acionista controlador e deliberações da assembleia geral ou dos órgãos de administração da companhia" (Abrasca, 2007, p.9).

Nesse contexto, as empresas precisam apoiar-se na informação como forma de emergir, considerando a necessidade de se realizar 
uma conexão entre a gestão estratégica e a comunicação organizacional. Destaca-se que essa é a expressão de seus processos de gestão, na medida em que cria não só o trânsito de informações entre as distintas áreas da empresa, mas também permite um relacionamento mais próximo entre as partes interessadas na empresa.

\section{Gestão da informação em contextos empresariais}

A gestão da informação tem como objetivo apoiar a gestão das empresas por meio de processos que tornem mais eficientes e acessíveis a informação e sua articulação em todos os âmbitos, de modo que a criação do conhecimento seja favorecida. Nesse sentido, implantar modelos de gestão da informação permite que as empresas possuam subsídios informacionais para o processo decisório, podendo assim selecionar a informação relevante para apoiar todas as fases dos processos de tomada de decisão. Os processos pautados pela gestão da informação contemplam todas as áreas de uma empresa, isso porque a informação é elemento fundamental para os fazeres de todas as rotinas empresariais.

Pela existência de fluxos informacionais, formais ou informais, a informação perpassa todos os ambientes da empresa, fazendo parte dos processos organizacionais de forma natural, podendo existir sob a forma registrada e não registrada. Os fluxos formais são decorrentes da própria estrutura da empresa, ou seja, rotinas e elementos aplicados aos fazeres produtivos, estando relacionados ao organograma da empresa. Nesse caso, a informação registrada perpassa os sistemas formais da empresa: portais corporativos, intranets, relatórios, registros, documentos contendo normas e códigos, entre outros. E sob a forma não registrada por meio de reuniões, cursos e eventos formalizados, mas não registrados em algum tipo de suporte.

Quanto aos fluxos informais, esses podem surgir espontaneamente, por meio de uma reunião ou até mesmo em conversas entre os funcionários, estando relacionados à estrutura intelectual de cada indivíduo atuante na empresa. Ressalte-se que os fluxos informais, 
em geral, assumem a forma não registrada, considerando se tratarem de diálogos e interações não formalizados entre sujeitos e, portanto, não registrados em suportes.

Esses fluxos informacionais, tantos formais quanto informais, são o elo entre uma fonte e um receptor, que resulta na transferência de informações. Em relação aos fluxos formais e informais de informação existentes em todas as áreas de uma empresa, Valentim (2002) argumenta que é possível mapear esses fluxos informais, assim como é possível estabelecer fluxos formais de informação, a partir do reconhecimento de três ambientes.

[...] o primeiro está ligado ao próprio organograma, isto é, as inter-relações entre as diferentes unidades de trabalho como diretorias, gerências, divisões, departamentos, setores, seções etc.; o segundo está relacionado à estrutura de recursos humanos, istoé, as relações entre pessoas das diferentes unidades de trabalho; e o terceiro e último é composto pela estrutura informacional, ou seja, geração de dados, informação e conhecimento pelos dois ambientes anteriores.

Assim, destaca-se que pelo conhecimento e aplicação de modelos efetivos para mapear, prospectar, filtrar, tratar e disponibilizar informações é possível otimizar os fluxos informacionais, propiciando seu uso racional e eficiente. É fundamental que uma empresa compreenda a importância de gerir de forma correta as informações existentes nos ambientes interno e externo, podendo assim obter vantagem competitiva, pautada por esse elemento que possui caráter estratégico quando gerido de forma eficiente. Contudo, a criação de mecanismos e modelos, bem como a organização de uma equipe de trabalho voltada às atividades de gestão da informação, é fundamental para que se reconheçam os fluxos informacionais e com isso seja possível a criação de vantagem competitiva.

Muitas empresas fazem grandes investimentos em tecnologia, mediante a implantação de ferramentas aplicadas à gestão da informação. Contudo, não estabelecem padrões de gestão que reconheçam de fato os elementos que possam ser prejudiciais e os que ofere- 
cem vantagem competitiva. Esse conceito da não utilização correta dos mecanismos de gestão da informação é destacado por Davenport \& Prusak (1998, p.12), que consideram que a abordagem comumente aceita para o gerenciamento de informações simplesmente por meio de investimento em novas tecnologias não funciona. Para os autores, "os administradores precisam, na verdade, de uma perspectiva holística, que possa assimilar alterações repentinas no mundo dos negócios e adaptar-se às sempre mutantes realidades sociais".

O modo como as empresas utilizam a informação vem sendo objeto de várias pesquisas, isso porque os conceitos acerca da gestão da informação encontram-se num momento de questionamento, tanto sobre as práticas estabelecidas como sobre as novas metodologias existentes. Choo (2003, p.23) relata que verificar o modo como as empresas usam a informação é mais difícil do que parece, considerando-se a informação um componente intrínseco de quase tudo o que uma empresa faz. Contudo, o autor explica que "Sem uma clara compreensão dos processos organizacionais e humanos pelos quais a informação se transforma em percepção, conhecimento e ação, as empresas não são capazes de perceber a importância de suas fontes e tecnologias de informação".

$\mathrm{O}$ autor define três arenas distintas em que a criação e o uso da informação desempenham um papel estratégico no desenvolvimento das empresas, considerando a atual concepção de "teoria organizacional".

- A empresa usa a informação para dar sentido às mudanças do ambiente externo.

- A empresa cria, organiza e processa a informação de modo a gerar novos conhecimentos por meio do aprendizado.

- As empresas buscam e avaliam informações de modo a tomar decisões importantes. (Choo, 2003, p.27-9)

No que tange ao ambiente externo, as empresas convivem com a pressão exercida pela concorrência, pelos próprios clientes e demais públicos que possuem interesse sobre os negócios da empresa, o que 
gera a necessidade de constante adaptação às alterações mercadológicas, sociais, políticas e econômicas. Em consequência, a empresa precisa interpretar antecipadamente as mudanças e gerar planos de ação que possibilitem o menor risco possível ao negócio da empresa. Nesse contexto, torna-se imperativo uma redefinição dos propósitos da empresa, a partir da ocorrência de mudanças que possam interferir no ambiente físico, no alinhamento das estratégias, no estabelecimento de parcerias, entre outros aspectos organizacionais, e, por isso mesmo, o papel da informação é decisivo. Segundo Choo (2003, p.28) "uma tarefa crucial da administração é distinguir as mudanças mais significativas, interpretá-las e criar respostas adequadas para elas".

Nesse ponto, é fundamental destacar a relação entre gestão da informação e gestão do conhecimento, isso porque os fazeres no âmbito empresarial são alicerçados pela gestão estratégica da informação e do conhecimento. Essa necessidade de distinção é fundamental, ainda que o contexto dessa seção seja a gestão da informação, isso porque, quando gerida de forma estratégica, essa acaba por assumir caráter fundamental para a criação do conhecimento. Assim, muito embora cada um dos termos possua objetivos distintos, existe uma relação estreita entre gestão da informação e gestão do conhecimento. Enquanto a gestão da informação atua diretamente nos fluxos formais, a gestão do conhecimento atua nos fluxos informais.

A gestão da informação atua diretamente com os fluxos formais, tendo como foco o negócio da informação agindo de forma restrita as informações contidas em suportes, sejam eles impresso, digital, entre outros [...] A gestão do conhecimento atua diretamente com os fluxos informais, tendo como foco o capital intelectual inferindo na comunicação empresarial. (Valentim, 2007, p.18-20)

No que tange à criação de novos conhecimentos, as empresas precisam reconhecer os elementos que abrangem a construção e a manutenção dos mecanismos de gestão do conhecimento. Para en- 
frentar as mudanças, é fundamental que a empresa seja capaz de captar e gerenciar o conhecimento como um ativo estratégico.

Para Somerville \& Mroz (1997, p.93), os investimentos em gestão do conhecimento devem ultrapassar os realizados em correio eletrônico, websites e intranets, ou seja, devem contemplar a gestão ativa de conhecimento por meio da disseminação de experiências vivenciadas, para que todos os indivíduos da empresa, de todos os níveis, possam ter acesso ao conhecimento acumulado na empresa e aplicá-los nos seus fazeres diários.

Apenas reconhecer que existe grande quantidade de conhecimento, no entanto, não proporciona, por si só, valor à empresa, isso porque o conhecimento deve ser aliado à gestão. A criação e a implantação de mecanismos que gerem, armazenem, gerenciem e disseminem o conhecimento representam o mais novo desafio a ser enfrentado pelas empresas. Para Choo (2003, p.28), "A construção e a utilização do conhecimento é um desafio para as empresas. Conhecimentos e experiências se encontram dispersos pela organização e se concentram em geral em determinados indivíduos ou unidades de trabalho". O mesmo autor relata a existência de empresas que "reinventam a roda" desnecessariamente, justamente por não gerir eficazmente o conhecimento gerado em seu ambiente organizacional.

No que se refere aos processos de tomada de decisão, a informação é fator importante para que a empresa possa identificar as questões relevantes (riscos e oportunidades), por meio da análise de cada situação. Para esse processo organizacional a informação é crucial, pois propicia ao tomador de decisão avaliar o peso e a viabilidade das distintas possibilidades que se apresentam para uma determinada situação. Muitas vezes, porém, a informação correta, no tempo certo, para a pessoa certa, propicia maior agilidade e velocidade aos processos organizacionais, fato que pode gerar certa pressão em todos os níveis da organização. Choo (2003, p.29) explica que, embora a tomada de decisão seja um processo complexo, não há dúvida de que ela é parte essencial da vida da organização. Para o autor, "toda ação da empresa é provocada por uma decisão, e toda decisão é um compromisso para uma ação” (ibidem). 
Para uma empresa, não basta adotar a estrutura correta, contratar os melhores profissionais e dispor de meios de comunicação corretos, pois para se tomar decisões apropriadas num ambiente complexo e de rápido desenvolvimento é necessário gerir de maneira eficaz as informações e compartilhar conhecimento entre os sujeitos organizacionais (Hanaka \& Hawkins, 1997, p.194).

Considerando todos esses aspectos mencionados acerca da gestão da informação e sua importância para o processo de criação do conhecimento, destaca-se que essa compreensão visa contribuir para o desenvolvimento de estratégias que apoiem o processo de tomada de decisão nas empresas. Destaca-se que a criação de modelos de gestão da informação deve ser vista como uma ação essencial, porque a maneira como os indivíduos, a sociedade e o mercado se comportam em relação à informação revela que a empresa também depende desse elemento para sua atuação e desenvolvimento.

Embora se possa considerar que a informação é importante para todas as empresas, independentemente do setor de atuação, é evidente que uma informação sobre determinado evento pode ser relevante para uma empresa do setor de mineração e pode não ser relevante para uma empresa do setor de aviação. Do mesmo modo, uma empresa cuja estrutura esteja pautada por modelos de governança corporativa possui um conjunto mais amplo de informações que devem ser geridas de forma diferente ao de uma empresa que não possui padrões de governança. Independentemente da missão, visão e objetivos de uma empresa, qualquer modelo de gestão da informação promoverá comportamento positivo em relação à informação em seus colaboradores. Nesse sentido, as empresas que melhor gerenciarem seus fluxos informacionais estarão mais bem preparadas para reagir favoravelmente às mudanças cada vez mais frequentes do mercado.

As empresas, de modo geral, não realizam a correta gestão de informações e documentos. É comum a contabilidade ser feita por departamentos que, em sua maioria, se limitam a fazer registros, relatórios contábeis e apontar os impostos a serem pagos, como se a contabilidade e a operação da empresa fossem coisas diferentes. Esse 
é apenas um exemplo da não utilização da informação de forma estratégica, considerando que frequentemente informações formatadas na contabilidade são insuficientes aos propósitos gerenciais. Uma série de informações importantes ao gerenciamento é fundamental para dar suporte aos processos, às tomadas de decisão e à melhoria contínua do desempenho da organização (Silva, 2006, p.73).

Tanto os relatórios financeiros quanto as demais informações relevantes podem limitar sua utilidade e, não raro, frustrar as expectativas dos usuários. A informação útil, portanto, passa a ser aquela que chega ao usuário no momento oportuno e no formato necessário para sua utilização. Nesse sentido, as estruturas de gestão da informação devem, portanto, contemplar modelos que otimizem os processos, especialmente no que diz respeito às demonstrações contábeis, aos fatos relevantes, aos elementos de divulgação da informação, o que inclui os canais de comunicação interno e externo, a gestão dos fluxos formais que devem seguir um rigor pautado por elementos de governança corporativa e critérios de auditoria. Do mesmo modo, a gestão dos fluxos informais, que podem representar um fator de risco para a empresa, visto que tais informações possuem um caráter mais específico, podendo, em alguns casos, ter o poder de manipular os mercados financeiros.

Nota-se que algumas empresas com nível de governança corporativa não tratam o gerenciamento da informação com o real objetivo de informar. A maioria dessas empresas utiliza a governança corporativa como padrão de gestão, e, ainda que a gestão da informação seja aplicada internamente, em alguns casos ela não satisfaz como poderia os stakeholders, ${ }^{1}$ pois se limita a disseminar apenas as informações que são obrigatórias.

1 Do inglês, o termo stakeholder designa uma pessoa, grupo de pessoas e instituições com legítimos interesses nas ações e no desempenho de uma organização. 


\section{Abertura de capital como fonte de captação de recursos}

O meio empresarial, de um modo geral, sofreu várias transformações em decorrência da internacionalização que teve, como uma de suas consequências, o avanço tecnológico e de inovações, colocando em destaque grandes corporações. Contudo, os movimentos causados pela internacionalização também levaram tantas outras empresas à busca de recursos para investimentos pesados com vistas a se adequarem à nova realidade do mercado. Nesse sentido, a base principal dessas transformações está na constante adaptação do meio empresarial a uma série de inovações, fator que tem levado muitas empresas a se preocuparem, cada vez mais, com a própria sobrevivência. Nesse contexto, as empresas buscam oportunidade de emergir por meio de investimentos aplicados em tecnologia, ampliação, contratação, como meio de buscar a sobrevivência em um mercado cada vez mais competitivo.

O desenvolvimento econômico de um país pode ser determinado pelo nível de sua atividade empresarial. Não é exagero afirmar, pois, que os pilares da economia de cada nação se alicerçam na eficiência de suas empresas, especialmente as constituídas como sociedades anônimas de capital aberto. Essa eficiência se traduz pela capacidade de produção e de geração de empregos, que decorre diretamente da aptidão das companhias de financiar seus investimentos, visando à redução de custos e melhorias da qualidade de seus produtos e serviços. (Garcia, 2005 p.7)

Essa necessidade de elevação da base de capital, como meio de suportar tais investimentos, muitas vezes pesados, não permite às grandes empresas se valerem somente dos mecanismos de financiamento convencionais. As empresas então recorrem ao mercado de capitais como uma fonte alternativa e sustentável de captação de recursos financeiros. Para Assaf Neto (2001, p.23), essa possibilidade de levantamento de recursos, que se apresenta como uma das mais vantajosas para as empresas que estão estabelecidas como socieda- 
des anônimas, possui um porte considerável, e possui produtos ou serviços bem aceitos pelos consumidores, é a abertura de capital com oferta pública de ações.

A Figura 1 apresenta o modelo clássico de fontes de financiamento para as organizações, considerando as possibilidades de fontes internas e externas.

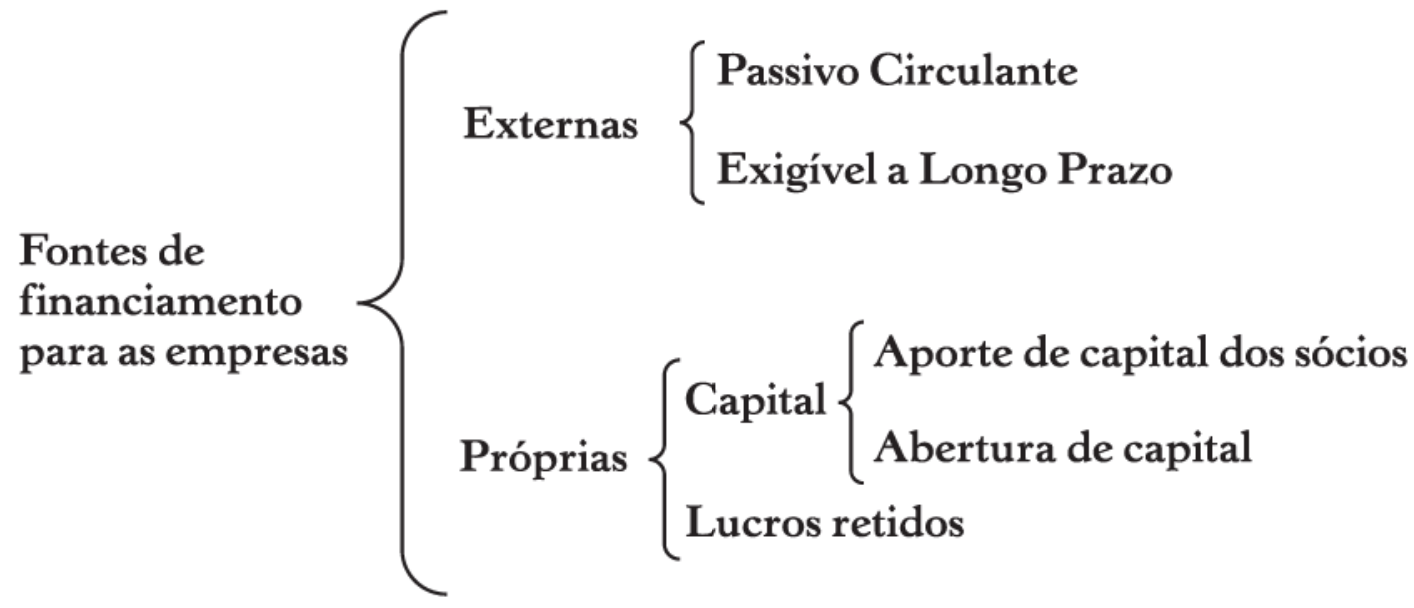

Figura 1 - Fontes de financiamento para a empresa.

Fonte: Pinheiro (2007, p.124).

É possível observar que o desenvolvimento do mercado de capitais na última década forneceu significativa parte do investimento necessário ao desenvolvimento de várias empresas. As empresas utilizam-se da abertura de capital com o objetivo de captar recursos dos investidores e com isso financiar seus projetos de investimento e se tornarem mais competitivas. Tal mecanismo de financiamento se dá basicamente pela integralização de recursos financeiros, feita pelo acionista na primeira compra de uma ação, ou seja, o recurso da primeira venda das ações pela empresa no momento em que essa abre o capital, denominado oferta primária, é o recurso que será utilizado para investimentos.

Na distribuição primária, a empresa emite e vende novas ações ao mercado. No caso, o vendedor é a própria companhia e, assim, os recursos obtidos na distribuição são canalizados para ela. Por sua vez, numa distribuição secundária, quem vende as ações é o empreendedor e/ou 
algum de seus atuais sócios. Portanto, são ações existentes que estão sendo vendidas. Como os valores arrecadados irão para o vendedor, ele é quem receberá os recursos, e não a empresa. Independentemente de a distribuição ser primária ou secundária, neste momento a companhia amplia o seu quadro de sócios, com os compradores das ações. Os investidores passam então a ser seus parceiros e proprietários de um pedaço da empresa. (BM\&FBovespa, 2009, p.5)

As ações representam a menor fração do capital social de uma empresa; portanto, ao adquirir uma ação de uma empresa, o acionista passa a ser um coproprietário com direito a participação em seus resultados. As ações não têm prazo de resgate, podendo ser convertidas em dinheiro a qualquer momento mediante negociação no mercado (Assaf Neto, 2001, p.18).

Essa alternativa de financiamento mediante a abertura de capital, em detrimento da captação de recursos via empréstimos ou injeção de recursos por parte dos acionistas, está intrinsecamente ligada ao desenvolvimento da organização à medida que ela adquire maiores possibilidades e vantagens como: acesso a recursos para financiar projetos de investimento, liquidez patrimonial, utilização das ações como forma de pagamento em caso de aquisições, criação de diferencial no que se refere à avaliação no negócio, fortalecimento da imagem institucional, entre outros benefícios.

\section{Governança corporativa}

A evolução constante das sociedades capitalistas traz uma nova relação entre as empresas e a sociedade, e, em muitos casos, essa evolução culmina na segregação entre os administradores das empresas e stakeholders. Essa desigualdade de poder entre controle e gestão pode provocar conflitos de interesses entre acionistas, investidores e demais interessados na empresa. Nesse contexto permeado por iminentes conflitos de interesses surge a governança corporativa como um processo que pode reduzir a distância exis- 
tente entre proprietários e administradores da empresa e a sociedade de maneira geral.

Sob essa perspectiva, os gestores contratados - ou em alguns casos sócios que exercem cargos de diretoria - para defenderem os interesses das empresas, cabam em muitos casos agindo de forma contrária, tomando decisões que visam atender aos próprios interesses. Contudo, o problema relacionado à conduta dos gestores não é a única questão que envolve os estudos sobre governança corporativa. As bases para o entendimento dos problemas de governança vão desde os problemas com gestores, passando pelos mecanismos de divulgação de informações até as ações que visam atender aos interesses dos pequenos acionistas. Esses elementos são o ponto de partida para se considerar e descobrir a melhor estrutura de governança corporativa para as empresas.

Os conceitos e modelos de governança corporativa vêm ao longo da última década sendo empregados na criação de mecanismos que possam superar esses inúmeros conflitos. Tais conceitos e modelos são regidos fundamentalmente por uma série de princípios determinantes da boa gestão, especialmente aqueles relativos a transparência, equidade, prestação de contas e, sobretudo, ética na condução dos negócios empresariais. Com relação ao conceito e princípios da governança corporativa o IBGC destaca que:

Governança Corporativa é o sistema pelo qual as organizações são dirigidas, monitoradas e incentivadas, envolvendo os relacionamentos entre proprietários, Conselho de Administração, Diretoria e órgãos de controle. As boas práticas de Governança Corporativa convertem princípios em recomendações objetivas, alinhando interesses com a finalidade de preservar e otimizar o valor da organização, facilitando seu acesso a recursos e contribuindo para sua longevidade. (IBGC, 2004, p.19)

Para a Comissão de Valores Mobiliários (CVM, 2002, p.2), governança corporativa é: 
o conjunto de práticas que tem por finalidade otimizar o desempenho de uma companhia ao proteger todas as partes interessadas, tais como investidores, empregados e credores, facilitando o acesso ao capital. A análise das práticas de governança corporativa aplicada ao mercado de capitais envolve, principalmente, transparência, equidade de tratamento dos acionistas e prestação de contas.

Ao definir a governança corporativa, Shleifer \& Vishny (1997, p.737) argumentam que a governança corporativa deve ser utilizada como um conjunto de mecanismos, por meio do qual o fornecedor de recursos, que é o investidor, possa garantir a obtenção para si do retorno sobre seu investimento de forma igualitária.

Essa interação entre investimento e retorno igualitário entre os acionistas perpassa o conceito da gestão pautada por critérios cujo foco é a separação entre propriedade e controle, de modo que todos os sócios tenham direitos iguais e que os majoritários não utilizem o controle como meio de obter vantagens para si. Nesse sentido, Siffert Filho (1998, p.125) argumenta que as questões de governança corporativa ganham maior relevância a partir do surgimento de organizações, nas quais há separação entre controle e gestão.

A separação de propriedade e controle entre acionistas e gestores, por meio da oferta pública de ações, fez que surgisse a necessidade de criação de mecanismos que alinhassem gestores e acionistas, a fim de atender aos interesses dos acionistas por parte dos controladores. A governança corporativa insere-se nessa temática, podendo ser definida como um conjunto de mecanismos internos e externos que visam harmonizar a relação entre gestores e acionistas (Silveira, 2002, p.2).

As discussões sobre a temática governança corporativa envolvem, sobretudo, a necessidade de criação de mecanismos que assegurem os direitos dos acionistas em relação às decisões corporativas. Escândalos recentes como das empresas WordCom, Xerox e Enron, envolvendo a manipulação das demonstrações financeiras, propagaram no ambiente de mercado de capitais uma crise de credibilidade. Essas grandes empresas americanas consideradas sólidas causa- 
ram com esses escândalos um enorme pânico entre investidores do mundo inteiro, após a descoberta de alterações e evasão de informações que maquiavam suas reais condições financeiras.

A proteção aos investidores passa a ser crucial, porque em muitos países a expropriação de recursos pelos acionistas controladores é ampla. As empresas utilizam como fonte de financiamento os recursos de investidores, que por sua vez enfrentam o risco de não obter retorno sobre seus investimentos, à vezes pela depreciação do valor das ações, mas em alguns casos porque ocorre por parte dos controladores a expropriação. Mediante esses fatores, a governança corporativa é considerada um conjunto de mecanismos por meio dos quais os pequenos investidores podem se proteger (La Porta et al., 2000, p.4).

As divergências nas relações, especialmente no tocante à transparência em relação às informações, têm sido colocadas como um importante aspecto nos processos de gestão e que sustentam a evolução da governança corporativa. A falta de transparência de muitas empresas e, até mesmo, sua conduta nem sempre correta com os acionistas minoritários são constantemente apontadas como origem para o mau funcionamento do mercado acionário, acarretando graves consequências para a eficiência da economia como um todo.

No contexto econômico e empresarial, a governança corporativa surge para procurar superar o conflito de agência, presente a partir do fenômeno da separação entre a propriedade e a gestão empresarial, pois o interesse daquele que administra a propriedade nem sempre está alinhado com o interesse de seu titular. Sob a perspectiva da teoria da agência, a maior preocupação é criar mecanismos eficientes, mediante sistemas de monitoramento e incentivos, que garantam que o comportamento dos executivos esteja alinhado com o interesse dos acionistas (IBGC, 2004).

A base do ativismo que levou o desenvolvimento das práticas de governança corporativa é o foco no monitoramento das organizações, por meio de mecanismos normativos que definem condutas internas e externas. Suas premissas baseiam-se em mecanismos de solução para o conflito de agência, decorrente da necessidade de si- 
metria informacional e solução de conflitos de interesses entre as partes envolvidas.

Nesse sentido, a principal discussão sobre a governança corporativa envolve a criação de mecanismos que assegurem que as decisões tomadas pelos controladores das organizações sejam tomadas de modo a atender de fato ao interesse dos investidores. As diferenças existentes no tratamento das partes relacionadas com as empresas têm origem na estrutura de propriedade. Tal hipótese é hoje um dos temas mais abordados e discutidos nas pesquisas acerca dos mecanismos de governança corporativa, já que a falta de informações sobre os direitos promovidos por esses mecanismos faz com que não sejam amplamente divulgados e, portanto, são pouco conhecidos pelos pequenos acionistas. Nesse sentido, defende-se que a simetria informacional é um dos pontos de partida para a garantia de que todas as partes obtenham informações fundamentais sobre as empresas, contudo encontra barreiras de acordo com o modelo de governança corporativa implantado. Isso porque os modelos de estrutura de propriedade pulverizada, como mencionado na seção anterior, ou seja, com participação ativa de grandes acionistas e fraca participação dos minoritários, podem proporcionar uma gestão e disseminação da informação que contempla as partes de forma desigual, podendo esse problema ser dirimido quando a participação efetiva compreende os majoritários e minoritários.

Desse modo, o principal impasse entre acionistas controladores e acionistas minoritários ainda ocorre nas empresas cujo controle é concentrado, o que diminui a participação dos minoritários, aumentando a assimetria informacional, em relação ao controle pulverizado, já que nesse caso na sua maioria a parte controladora é privilegiada. Em pesquisa realizada em 49 países, La Porta et al. (apud Leal \& Valadares, 2002, p.4) apontam a existência de forte correlação negativa entre a qualidade da proteção legal aos investidores e a estrutura de propriedade. Nesse âmbito, a governança das empresas é afetada pela sua estrutura de propriedade.

Todos os conceitos e definições acerca dos modelos de governança corporativa apresentam o que deve ser feito pelas empresas; contu- 
do, ainda que exista uma crescente preocupação por partes das empresas com capital aberto pela busca de padrões pautados pela boa governança, ainda há muito que ser feito. Nesse contexto, possivelmente pela jovialidade do tema, existe a impressão de que os sistemas de governança corporativa são vistos como a resolução para todos os problemas das empresas com capital aberto. De acordo com Brandão (2008, p.31), algumas empresas buscaram nos sistemas de governança corporativa benefícios chamados de externos, isto é, "eu preciso de dinheiro, tenho que ir à bolsa e, se eu não tiver boas práticas de governança, não vão querer ser meus sócios". Outras empresas, no entanto, adotam boas práticas de governança porque elas são úteis para disciplinar a tomada de decisão, independentemente de haver necessidade de recursos financeiros.

A conjunção de fatores que promoveu os conceitos e modelos de governança corporativa vai desde escândalos corporativos, boa intenção de algumas empresas e até oportunismo de outras. De um modo geral, a adesão às práticas de governança é vista como uma indicação da postura das empresas em relação aos valores como transparência, integridade, equidade. Contudo, essa adesão não garante que haja de fato um avanço nas relações. Entre os maiores desafios, está a melhoria na transparência das informações, desafios de gestão com relação à separação entre propriedade e controle, equidade entre as partes, estrutura do conselho de administração, relacionamento com auditoria.

\section{Governança corporativa e gestão da informação}

A gestão da informação é o mecanismo capaz de fornecer suporte à grande parte dos elementos vitais da governança corporativa. Isso porque, além das disposições legais que contemplam as exigências quanto aos processos de coleta, organização, uso e divulgação de informações de empresas de capital aberto, existe o fato de que os agentes participantes do mercado, sejam eles analistas ou investidores, utilizam-se de informações relevantes sobre as empresas para balizar suas análises, seja para recomendações ou para investimen- 
tos. Por isso, é fundamental que as empresas, mediante os modelos de governança corporativa, estabeleçam padrões de gestão da informação que contemplem todos os interessados.

Ao analisar os impactos da gestão da informação no âmbito da governança corporativa, Willis (2005, p.90) argumenta que a gestão da informação é insumo fundamental para a boa governança. O autor aborda algumas questões que demonstram a importância da gestão da informação nesse contexto.

- Sólida gestão de informação e de registros fornece transparência.

- Sólida gestão de informação e de registros permite a prestação de contas.

- Sólida gestão de informação e de registros sustenta os processos.

- Sólida gestão de informação e de registros demonstra o cumprimento de regras.

- Sólida gestão de informação e de registros é demandada por inúmeros requerimentos legais e estatutários.

- Gestão de informação e de registros proporciona segurança da informação, pessoal e corporativa.

A compreensão sobre a importância da implantação de modelos e mecanismos que monitorem e acompanhem o desempenho dos processos de gestão da informação deve considerar o fato de que os acionistas minoritários adquirem participação nas empresas por meio do mercado de capitais. Nesse contexto, é fundamental que se atente ao fato de que o preço de uma ação representa o equilíbrio entre as forças de oferta e demanda no mercado de capitais. Nesse sentido, os preços das ações indicam as expectativas futuras dos investidores em relação ao desempenho das empresas, à medida que as análises que formulam essas expectativas são baseadas nas informações disponíveis para a formação desses preços. Para Fama (1970, p.388), um mercado pode ser considerado eficiente quando os preços dos ativos refletem as informações disponíveis. Nesse mercado, os preços dos ativos são um sinal do verdadeiro valor dos ativos.

Defende-se que a utilização de mecanismos que atendam às necessidades informacionais dos participantes do mercado é crucial. 
Ainda que as empresas atendam às leis e aos regulamentos, é possível que sejam disponibilizadas mais informações e, sobretudo, que os mecanismos alcancem todos os interessados em obter tais informações. Nesse sentido, é importante que a empresa, ao desenvolver seus modelos de governança e de gestão da informação, considere se existe mais espaço para melhorias, observando a necessidade de maior rigor, já que os preços das ações refletem as expectativas sobre o desempenho futuro da empresa.

Mais específicos para a empresa são os aspectos que apontam a conduta dos gestores, o relacionamento com conselhos, o rigor das auditorias e, especialmente, as informações sobre os negócios que podem levar ao crescimento da empresa. Para Mahoney (2003, p.7), os investidores precisam ter um entendimento profundo sobre esses aspectos que serão utilizados como base para avaliação do progresso que está sendo alcançado pela empresa. A qualquer momento esses aspectos podem estar se movendo em direções positivas ou negativas, ou podem estar parados em posição neutra. Ajudar os investidores a acessá-los com precisão é a chave para ter as ações da empresa avaliadas corretamente.

Considerando que os conceitos e modelos da governança corporativa visam resguardar os interesses dos stakeholders, acredita-se que por meio da correta gestão da informação, aliada aos elementos da governança corporativa, é possível evitar a existência de informações e ações ocultas. Desse modo, as práticas de governança corporativa deveriam ser norteadas, especialmente, por controles de gestão da informação mais eficientes, que permitam aos interessados pela empresa concluir de forma mais segura sobre a existência ou não de transparência nos atos de sua gestão.

Nesse contexto, torna-se oportuno o debate sobre as ações das empresas no que se refere à gestão da informação. No contexto das empresas com capital aberto e com níveis de governança corporativa, a correta gestão da informação implica a adoção de práticas relativas aos aspectos estratégicos. Contudo, os elementos discutidos no âmbito desse trabalho abordam elementos de transparência, cujo foco é a qualidade da informação disponibilizada aos investidores. Cai et 
al. (2008, p.19) argumentam que os resultados da governança corporativa dependem da redução da assimetria de informações adicionais, isso porque as informações podem fornecer aos participantes do mercado evidências para apoiar a noção de que as empresas estão comprometidas de fato com os padrões de governança.

Defende-se que a gestão da informação no âmbito da governança corporativa deve enfocar os seguintes elementos:

1. Estrutura interna de gestão de informações que podem envolver:

- Descrição documental sobre as políticas de relacionamento entre conselho/direção/acionistas.

- Elaboração e divulgação de código de ética dos principais executivos.

- Divulgação dos critérios de poder dado aos executivos.

- Criação de comitês de auditoria para acompanhamento das informações geradas e divulgadas.

- Instrumentos de avaliação de desempenho de executivos e conselheiros.

2. Critérios de disseminação de informações relevantes:

- Implantação de instrumentos e procedimentos de gestão de risco.

- Maior divulgação sobre remuneração de diretores e conselheiros.

- Criação de políticas de divulgação voluntária, adicionais e exigidas legalmente.

- Criação de instrumentos que coíbam práticas de uso de informações privilegiadas.

- Criação de mecanismos que possam facilitar o acesso a informações sobre governança corporativa entre os pequenos acionistas.

- Criação de mecanismos para facilitar a participação de acionistas em assembleias, como voto eletrônico.

- Utilização de mecanismos para relacionamento com investidores.

- Criação de modelos de divulgação de informações quanto à estrutura financeira, condições, desempenho e perspectivas para a empresa. 
3. Eficácia do website como suporte das informações divulgadas:

- Utilização de critérios de usabilidade rigorosos para a área de divulgação de informações no website, tais como conteúdo, localização e navegação.

- Utilização de pesquisas para avaliação do conteúdo acessado visando à melhor gestão desse quesito.

- Disponibilização de profissionais da empresa ligados ao relacionamento com investidores.

- Criação de mecanismos de acesso para compartilhamento de informações entre a empresa e os participantes do mercado.

- Criação de mecanismos tecnológicos cujas linguagens permitam a coleta de informações financeiras.

Todos esses aspectos configuram-se como alguns dos elementos fundamentais para a qualidade da governança corporativa. Como todos são permeados por informações, sejam as decorrentes de fluxos formais, sejam as de fluxos informais, sob a forma registrada ou não registrada, defende-se que esses aspectos devem ser aliados aos elementos da gestão da informação. Isso deve ser considerado, já que a empresa precisa unir à sua gestão a capacidade de ter suas ações avaliadas corretamente pelos stakeholders mediante as informações disseminadas. Nesse sentido, inserir modelos de gestão da informação direcionados tanto ao contexto interno quanto ao externo pode contribuir de forma efetiva na adoção de mecanismos que norteiam a criação de plataformas e sistemas de informação; instrumentos de gestão e de controle operacional; padrões de comunicação e mídias utilizadas; compartilhamento de informações entre a empresa e os investidores; e, sobretudo, o conhecimento quanto ao posicionamento de todas as partes relacionadas com a empresa.

\section{Considerações finais}

A divulgação transparente e oportuna de informações por parte das empresas com capital aberto, especialmente as que seguem mo- 
delos de governança corporativa, é fundamental para os seus usuários no processo de tomada de decisões. Isso porque, a evidenciação clara, objetiva e coesa possibilita um maior grau de confiabilidade e segurança ao se decidir por uma alternativa em detrimento de outras. Atualmente, existem inúmeras normatizações (leis, pareceres, instruções) que tornaram a divulgação de várias informações obrigatória para as companhias abertas. No entanto, existem outras informações cuja divulgação é de caráter voluntário e que fazem parte de fatores independentes da imposição legal, tais como conscientização da necessidade e respeito a todas as partes interessadas.

No âmbito da governança corporativa, as estruturas de gestão da informação interna e externa são fundamentais, isso porque a empresa gera grande quantidade de informações que são utilizadas por um número significativo de usuários. Muito embora haja uma demanda de informações semelhantes, essas visam satisfazer as necessidades específicas de usuários individuais, que possuem motivações e necessidades distintas quanto ao uso dessas informações. A dependência dos usuários externos em relação às informações que recebem sobre as empresas exige que haja um rigor quanto à coleta, seleção, organização, uso e disseminação. Esse rigor pode evitar que ocorram fatos que, por alguma razão, não foram disseminados de forma precisa ou oportuna ao público externo, causando muitas vezes perdas financeiras.

Nesse sentido, destaca-se a importância da utilização de modelos de gestão da informação em conjunto com os modelos de governança corporativa. Considerando que os modelos de governança possuem como foco principal a elaboração e implementação de critérios de divulgação de informações relevantes, percebe-se que para as empresas que fazem parte desse contexto é importante considerar a gestão da informação pautada por modelos que otimizem os fluxos informacionais, as tecnologias envolvidas nesse processo, bem como os impactos causados pelas informações divulgadas de modo que tais informações possam criar valor tanto para os usuários internos quanto para os externos. 


\section{Referências}

ABRASCA - Associação Brasileira de Companhias Abertas. Manual Abrasca de controle e divulgação de informações relevantes. São Paulo, 2007.

ASSAF NETO, A. Mercado financeiro. 4.ed. São Paulo: Atlas, 2001.

BM\&FBOVESPA. Como e por que tornar-se uma Cia. aberta. São Paulo, 2009. Disponível em: <http://www.bovespa.com.br/pdf/ guiaaber.pdf >. Acesso em: 31 set. 2009.

BRANDÃO, C. E. L. Conceitos em governança corporativa. Debates GVsaúde, São Paulo, n. 5, 2008.

CAI, J et al. Information asymmetry and corporate governance. Drexel College of Business Research, Philadelphia, n.2, 2008.

CHOO, C. W. A organização do conhecimento: como as organizações usam a informação para criar significado, construir conhecimento e tomar decisões. 2.ed. São Paulo: Senac Editora, 2003. 425p.

CVM - Comissão de Valores Mobiliários. Recomendações sobre governança corporativa da CVM. São Paulo, 2002. Disponível em: <http:/ /www.cvm.gov.br/port/public/publ/cartilha/cartilha.doc>. Acesso em: 3 set. 2009.

DAVENPORT, T. H.; PRUSAK, L. Ecologia da informação: por que só a tecnologia não basta para o sucesso na era da informação. São Paulo: Futura, 1998.

FAMA, E. F. Efficient capital markets: A review of theory and empirical work. The Journal of Finance, New York, v.25, n.2, p.383-417, May 1970.

GARCIA, T. M. e S. Governança corporativa e o conflito de interesses nas sociedades anônimas. São Paulo: Atlas, 2005.

HANAKA, M. E.; HAWKINS, B. Organizando para a vitória contínua. In: DRUCKER, P. F. (Org.) A organização do futuro: como preparar hoje as empresas de amanhã. São Paulo: Futura, 1997. p.187-94.

IBGC - Instituto Brasileiro de Governança Corporativa. Código das melhores práticas de governança corporativa. 3.ed. São Paulo, 2004.

LA PORTA, R. et al. Investor protection and corporate governance. Journal of Financial Economics, v.58, p.3-27, Oct. 2000. 
LEAL, R.; VALADARES, S. Ownership and control structure of Brazilian companies. Unpublished Working Paper. Disponível em: <http://ssrn.com/abstract=213409 or doi:10.2139/ssrn.213409>. Acesso em: 18 set. 2009.

MAHONEY,W. F. O que importa é a qualidade da informação. Revista RI, Rio de Janeiro, n.66, p.6-8, ago. 2003.

PINHEIRO, J. L. Mercado de capitais: fundamentos e técnicas. 4.ed. São Paulo: Atlas, 2007. 354p.

SHLEIFER, A.;VISHNY, R. A survey of corporate governance. Journal of Finance, v.52, n.2, p.737-83, 1997.

SIFFERT FILHO, N. Governança corporativa: padrões internacionais e evidências empíricas no Brasil nos anos 90. Revista do BNDES, Rio de Janeiro, p.123-46, jun. 1998.

SILVA, E. C. Governança corporativa nas empresas: guia prático de orientação para acionistas. São Paulo: Atlas, 2006.

SILVEIRA, A. D. M. Governança corporativa, desempenho e valor da empresa no Brasil. São Paulo, 2002.152p. Dissertação (Mestrado)Faculdade de Economia e Administração e Contabilidade, Universidade de São Paulo.

SOMERVILLE, I.; MROZ, J. E. Novas competências para um novo mundo. In: DRUCKER, P. F. (Org.) A organização do futuro: como preparar hoje as empresas de amanhã. São Paulo: Futura, 1997. p.84-98.

VALENTIM, M. L. P. Inteligência competitiva em organizações: dado, informação e conhecimento. DataGramaZero, Rio de Janeiro, v.3, n.4, ago. 2002. Disponível em: <http://dgz.org.br/ago02/ Art_02.htm>. Acesso em: 14 nov. 2009.

Processo de inteligência competitiva organizacional. In: VALENTIM, M. L. P. (Org.) Informação, conhecimento e inteligência organizacional. 2.ed. Marília: Fundepe Editora, 2007. p.9-24

WILLIS, A. Corporate governance and management of information and records. Records Management Journal, Canberra, v.15, n.2, p.8697, 2005. 



\section{4 \\ A FORMAÇÃO DO BIBLIOTECÁRIO E A COMPETÊNCIA INFORMACIONAL: UM OLHAR ATRAVÉS DAS COMPETÊNCIAS}

Marta Leandro da Mata

Helen de Castro Silva Casarin

\section{Introdução}

A sociedade da informação representa uma profunda mudança nos setores econômicos, políticos e sociais. As tecnologias propiciaram a aceleração da sua produção e disseminação, movimentando altos fluxos informacionais por meio de diversos canais de comunicação.

Essa nova economia baseada na informação e nas tecnologias traz consigo novos dilemas para a educação, especialmente em relação à formação que vem oferecendo aos seus estudantes. O sistema educacional deve acompanhar as tendências atuais, colocando o aprendiz no centro do processo, preparando-o para aprender a aprender e para ter condições de viver no séculoXXI. De acordo com Takahashi (2000, p.7), "éa educação o elemento-chave para a construção de uma sociedade da informação e condição essencial para que pessoas e organizações estejam aptas a lidar com o novo, a criar e, assim, a garantir seu espaço de liberdade e autonomia".

A formação que deve ser oferecida no período de escolarizaçãoé passível de muitas discussões. As preocupações atuais referem-se às competências necessárias para viver no momento presente e futuro diante de tantas diversidades, como as mencionadas no Relatório Delors (1998), trazendo novas abordagens como o aprender a aprender. 
O aprender a aprender e o aprendizado ao longo da vida são preocupações que envolvem todos os segmentos profissionais voltados para o cenário educacional. A ciência da informação/biblioteconomia também vem discutindo a esse respeito por meio da competência informacional, focando a informação como recurso educacional, buscando contribuir para a aprendizagem dos indivíduos mediante programas instrucionais que os auxiliam a manusear as ferramentas informacionais.

A competência informacional volta-se para a formação do indivíduo, colocando-o no centro do processo de aprendizagem. Procura habilitá-lo a usar a informação, fazendo-o tomar conhecimento dos suportes em que a informação encontra-se disponível para poder localizá-la, selecioná-la e, por fim, usá-la. Desse modo, possibilita-lhe conquistar a sua autonomia, orientando-o para o aprender a aprender.

A competencia informacional faz parte de um processo que se constrói conjuntamente com os educadores e com as instituições de ensino, auxiliando-os a alcançar as suas metas em relação à formação dos indivíduos e ao seu desenvolvimento como profissionais e cidadãos, pois "é algo trabalhado continuamente, observando, interpretando, compartilhando, questionando, elaborando críticas, hipóteses e explicações" (Cavalcante, 2006, p.57).

Nesse sentido, o oferecimento de bases que sustentem a formação acadêmica dos estudantes direciona a um aprendizado independente, ao aprender a aprender e à construção do aprendizado ao longo da vida, pois a "competência informacional é uma questão que faz parte do processo educacional a que todos têm direito e seu acesso deve ser divulgado e incentivado" (Lecardelli \& Prado, 2006, p.40).

Assim, supõe-se que a biblioteca e as instituições de ensino devem estar ancoradas em um mesmo objetivo, de formar aprendizes capazes de analisar, interpretar, refletir, aprender a aprender e aprender ao longo da vida para que possam tomar decisões éticas e contribuir para o desenvolvimento do país e da sociedade, de acordo com Teterycs (2008, p.4): 
A principal meta de todo o sistema de educação é fazer com que o educando adquira o conhecimento que ele possa aplicar em diversas situações de sua vida pessoal e prof issional. Para isso, a instituição de ensino deve ter a preocupação com a formação do pensamento crítico de seus educandos, preparando-os para a autonomia e o comprometimento social.

Na educação superior, são crescentes as preocupações com a formação de futuros profissionais, com as competências que devem possuir para fazerem frente ao mercado de trabalho e viverem como cidadãos capazes de agregar novos conhecimentos ante uma sociedade em constante mutação.

Nesse contexto, pretendeu-se levantar algumas questões referentes à formação do bibliotecário, conduzindo-se a algumas considerações sobre a competência informacional do bibliotecário. Tal reflexão se justifica pelo fato de que o bibliotecário pode ser um dos principais agentes propagadores do conceito da competência informacional, responsável pela criação e desenvolvimento de programas sobre a temática.

Para o bibliotecário, como profissional e agente educacional atuante, é imprescindível ser competente em informação, pois sua atuação deverá resultar em benefícios para todos os envolvidos no processo de ensino-aprendizagem e, consequentemente, para a sociedade.

\section{Abordagem sobre as competências e a formação do bibliotecário}

As exigências do cenário atual abriram novas perspectivas para biblioteconomia. Os locais e as formas de atuação profissional foram ampliados em razão da natureza de sua matéria-prima, a informação. Abrem-se, por exemplo, novas frentes para organização da informação em variados ambientes e suportes, bem como há a ampliação do papel social e educacional do bibliotecário. 
As mudanças no mercado de trabalho e na sociedade fizeram que os cursos formadores rediscutissem os papéis e as formas de atuação do bibliotecário. Assim, alguns aspectos de sua formação passaram a ser revistos e as escolas passaram a olhar mais atentamente para os planos de ensino e seu conteúdo programático. Algumas escolas focaram mais os aspectos humanos da questão, enquanto outras, os aspectos tecnológicos, todas atentas às tendências do mercado de trabalho e tentando oferecer disciplinas aos seus alunos com o objetivo de torná-los profissionais altamente qualificados (Allendez Sullivan, 2004).

Observa-se que as escolas de Biblioteconomia devem deixar explícitos em seus projetos pedagógicos o perfil, as funções e o papel dos profissionais que estão formando, objetivando que os futuros profissionais da área conheçam realmente a sua profissão. De acordo com Valentim (2000, p.140), "a formação obtida na graduação é absolutamente necessária, é alicerce na formação desse prof issional, na medida em que o indivíduo aprende a relacionar a teoria e a práxis antes de atuar no mercado de trabalho".

Os bibliotecários precisam de certas competências para poder desempenhar seu papel na sociedade e no mercado de trabalho, e as escolas formadoras devem estar atentas ao desenvolvimento dessas competências em seus estudantes durante o período de formação acadêmica. Em razão da complexidade das competências requisitadas, começaremos a discorrer sobre as competências básicas, genéricas e específicas, baseando-nos nos conceitos descritos por Tejada Artigas \& Tobón Tobón (2006).

As competências básicas são consideradas essenciais para viver em sociedade e desenvolver-se nela. Dentro das competências básicas encontram-se as competências cognitivas de processamento da informação. Pode-se discernir entre três competências básicas: a interpretativa, a argumentativa e a propositiva.

A interpretativa busca desenvolver o conhecimento e as habilidades; a argumentativa eleva a capacidade de raciocínio em qualquer execução e compreende, por um lado, a exposição da tese, a apresentação de argumento e, por outro, o emprego de conceitos 
básicos; a propositiva se refere à formulação de propostas para a solução de problemas (Posada Alvarez apud Tejada Artigas \& Tobón Tobón, 2006). De um modo geral, as competências básicas são inerentes a todos os seres humanos.

As competências genéricas são comuns a várias profissões, ou seja, trata-se de competências essenciais em um conjunto de profissionais, representam as atividades comuns a diferentes áreas. Elas permitem aos alunos adaptarem-se com maior facilidade às contínuas mudanças do mercado de trabalho, propiciando uma educação acadêmica mais ampla e abrangente. Incluem-se nelas atividades como o trabalho em equipe, a gestão da informação, a compreensão sistêmica, a resolução de problemas e a organização do trabalho.

Em relação ao trabalho em equipe (o trabalho conjunto entre profissionais), podem-se ressaltar as atividades desenvolvidas com os profissionais da área de informática como para a implantação de software nas unidades de informação para a organização da informação; ou pode-se ressaltar ainda o trabalho do bibliotecário, ao atuar em instituições educacionais, junto a educadores, administradores e outros membros da instituição.

Nos programas de competência informacional, o trabalho conjunto entre os educadores, os administradores e outros membros da instituição educacional é muito importante, assim como é importante a visão e compreensão sistêmica que possuem em relação à universidade e à organização do trabalho. A ACRL (2000) destaca:

Através de suas aulas e do estímulo à discussão, os professores estabelecem o contexto para a aprendizagem; também inspiram os estudantes para que explorem o desconhecido, oferecem guia e conselho sobre como satisfazer melhor as necessidades de informação e controlam o progresso dos estudantes. Os bibliotecários coordenam a avaliação e seleção dos recursos intelectuais para os programas e serviços; organizam e mantêm as coleções e pontos de acesso à informação; e oferecem formação para os estudantes e professores na hora de buscar a informação. Os administradores criam as oportunidades para a colaboração e o desenvolvimento profissional permanente dos professores, bibliotecários e outros profissionais que iniciem programas de competência em 
informação, administram o planejamento e os orçamentos de tais programas e oferecem os recursos necessários para mantê-los.

O bibliotecário deve possuir outra competência genérica essencial. Trata-se de um pré-requisito da área em razão das atividades pedagógicas que devem desenvolver nas instituições de ensino. $\mathrm{O}$ bibliotecário precisa possuir didática, conhecer os instrumentos e métodos de ensino para ter capacidade de ensinar/orientar a comunidade usuária em programas de competência informacional, de educação de usuários e mesmo de treinamentos.

Percebe-se que a formação curricular do bibliotecário deve proporcionar um aprendizado voltado também para os aspectos pedagógicos, já que em certas situações ele deverá assumir, em seu cargo, a posição de educador. Nos locais onde existe a implicação direta do bibliotecário com a competência informacional, esse é convertido em um formador, necessitando então conhecer alguns princípios didáticos (Salas Lamadrid, 2008).

As competências específicas são aquelas próprias de uma determinada profissão, podendo distinguir-se entre competências obrigatórias (aquelas indispensáveis para obter a titulação), as optativas (aquelas específicas em um posto de trabalho) e as adicionais (para funções muito especializadas em uma área) (Tejada Artigas \& Tobón Tobón, 2006).

As competências específicas da profissão do bibliotecário abrangem variados saberes relacionados ao tratamento e à organização da informação. Sua formação pressupõe que ele tenha qualificação para o uso das fontes de informação disponíveis em todos os formatos e meios, sejam elas impressas e/ou multimídias, e que esteja preparado para seleção, aquisição, tratamento e disseminação da informação, recuperando-a quando necessário. E em razão desses saberes específicos que esse profissional é considerado o ideal para trabalhar na formação de habilidades relacionadas ao processo de uso das fontes de informação, isto é, da competência informacional. A seguir, apresenta-se o Quadro 1 sobre as competências básicas, genéricas e específicas: 
Quadro 1 - Classificação das competências básicas, genéricas e específicas

\begin{tabular}{lll}
\hline BÁSICAS & GENÉRICAS & ESPECÍFICAS \\
\hline $\begin{array}{l}\text { Essenciais para viver } \\
\text { em sociedade }\end{array}$ & $\begin{array}{l}\text { Comuns a } \\
\text { várias profissões }\end{array}$ & $\begin{array}{l}\text { Próprias de uma } \\
\text { determinada profissão }\end{array}$ \\
\hline $\begin{array}{l}\text { Interpretativa } \\
\text { Argumentativa }\end{array}$ & $\begin{array}{l}\text { Gestão de recursos } \\
\text { Propositiva }\end{array}$ & $\begin{array}{l}\text { Possuem um alto grau de } \\
\text { especialização }\end{array}$ \\
& $\begin{array}{l}\text { Gestão da informação } \\
\text { Compreensão sistêmica } \\
\text { Resolução de problemas }\end{array}$ & $\begin{array}{l}\text { Podem ser obrigatórias, } \\
\text { optativas e adicionais }\end{array}$ \\
& Organização do trabalho & \\
\hline
\end{tabular}

Fonte: Tejada Artigas \& Tobón Tobón (2006, p.36).

Essa descrição das competências básicas, genéricas e específicas aponta a complexidade e diversidade necessárias para o desempenho profissional e social dos bibliotecários, bem como para que ele possa ser capaz de auxiliar na descrição das competências profissionais em informação e documentação, próprias de sua profissão. De acordo com Tejada Artigas \& Tobón Tobón (2006), as competências profissionais em informação do bibliotecário devem originar-se a partir do conjunto de conhecimentos, habilidades e atitudes desenvolvidos por ele para alcançar o papel de sua profissão.

Os mesmos autores descrevem um esquema de competências profissionais em informação e documentação contendo cinco núcleos, que correspondem às competências e atividades requeridas para o desempenho da profissão de bibliotecário, a saber: as competências em informação, as competências em comunicação, as competências no ciclo de gestão, as competências na aplicação das tecnologias de informação e as competências gerais e sobre o ambiente (ibidem).

Essas cinco competências decorrem em geral das várias atividades que o bibliotecário deve desenvolver durante sua atuação profissional. As competências em informação, especificamente, envolvem o processo informativo desde a busca e recuperação da informação até a disponibilização aos usuários. 
As competências comunicativas envolvem a relação com os usuários por meio de vários canais de comunicação. As competências no ciclo de gestão, por sua vez, envolvem responsabilidades inerentes às unidades de informação, como os processos administrativos e as tomadas de decisão sobre a instituição biblioteca e seu universo informacional, encontrando-se ligadas, em suma, ao desenvolvimento de coleções e à gestão de unidades de informação.

As competências na aplicação das tecnologias dizem respeito ao uso das tecnologias nas unidades de informação, devendo os profissionais ali atuantes possuir familiaridade com elas, visando atender e satisfazer às necessidades informacionais de seus usuários. $\mathrm{O}$ uso das tecnologias envolve os softwares de auxílio na organização da informação, no armazenamento e na difusão de informações em ambiente eletrônico, entre outros.

$\mathrm{E}$, finalmente, as competências gerais e sobre o ambiente são aquelas que se concentram na natureza mediadora da função informativa, como o bibliotecário realizando a mediação entre a informação e os usuários das bibliotecas. Caracterizam-se também pela capacidade de dar respostas adequadas em um determinado contexto e de aplicar conhecimentos variáveis em uma determinada situação (Tejada Artigas \& Tobón Tobón, 2006).

As competências gerais e do ambiente estão articuladas com os conhecimentos que os bibliotecários devem possuir sobre a cultura, de modo a poder atuar no meio em que vivem, de acordo com os princípios e finalidades que a sociedade demanda, além de ter uma formação humanística. Conforme Silva (2003, p.80), o bibliotecário precisa ter "uma formação com maior densidade filosófica, sociológica e histórica que fornecesse [...] subsídios para exercitar uma crítica profunda à estrutura e ao funcionamento do aparelho escolar brasileiro".

Uma formação com os aspectos descritos pela autora possibilitaria aos bibliotecários adquirir uma capacidade maior de reflexão e senso crítico para avaliar os acontecimentos atuais e discutir com propriedade os problemas enfrentados pela sociedade de um modo geral, que sempre afetam as instituições educacionais e, consequentemente, toda a sua estrutura, como as bibliotecas. A formação pen- 
sada desse modo possibilitaria a aquisição e desenvolvimento das competências gerais e culturais.

Alguns órgãos da área de biblioteconomia têm se preocupado com o rol de competências desses graduandos e dos profissionais bibliotecários. Entre elas, a Special Libraries Association (SLA), que elaborou um documento sobre as competências do profissional da informação no século XXI (Abels et al., 2003).

A SLA é uma organização de profissionais da informação que tem explorado e compartilhado sua visão das competências e habilidades exigidas para a administração da informação especializada em muitos foros durante anos. No documento mencionado, descrevese o que é um profissional da informação e o que são as organizações informacionais, bem como suas competências necessárias, profissionais e pessoais (ibidem).

As competências profissionais, conforme Abels et al. (2003), relacionam-se ao conhecimento dos recursos informacionais, ao acesso desses recursos, às tecnologias e à administração deles, às habilidades para usar o conhecimento como base para melhorar a qualidade dos serviços de informação. As quatro maiores competências profissionais são:

- Administrar as organizações informacionais.

- Administrar os recursos informacionais.

- Administrar os serviços informacionais.

- Aplicar tecnologias e ferramentas de informação.

As competências pessoais são representadas por um conjunto de atitudes e valores capazes de habilitar os profissionais a trabalhar efetivamente e contribuir para com suas organizações, clientes e profissão. A SLA acredita que tanto a competência profissional como a pessoal são essenciais para o desenvolvimento ao longo da vida e/ou carreiras dos profissionais da informação (ibidem).

As competências são apresentadas em formato de padrões, com os tópicos descritos e numerados; e, na sequência, são apresentados os cenários de aplicação de cada uma delas. 
As competências específicas da profissão enfatizam os aspectos informacionais, que condizem com aquisição, seleção, organização, recuperação e disseminação da informação, ou seja, com o tratamento e a organização da informação, que são funções desempenhadas pelos bibliotecários já há muito tempo. Aquilo que há de novo em sua forma de atuação decorre das mudanças causadas pelas tecnologias informacionais, que multiplicaram a quantidade de informações, os formatos e meios de armazenamento e as formas de acesso.

No Brasil, as competências e habilidades que os graduandos de biblioteconomia devem possuir foram traçadas pelo Ministério da Educação (MEC), visando orientar na criação de currículos na área (Brasil, 2001). Essas competências dividem-se em gerais e específicas, como segue:

Competências e habilidades gerais:

- Gerar produtos a partir dos conhecimentos adquiridos e divulgá-los.

- Formular e executar políticas institucionais.

- Elaborar, coordenar, executar e avaliar planos, programas e projetos.

- Utilizar racionalmente os recursos disponíveis.

- Desenvolver e utilizar novas tecnologias.

- Traduzir as necessidades de indivíduos, grupos e comunidades nas respectivas áreas de atuação.

- Desenvolver atividades profissionais autônomas, de modo a orientar, dirigir, assessorar, prestar consultoria, realizar perícias e emitir laudos técnicos e pareceres.

- Responder a demandas sociais de informação produzidas pelas transformações tecnológicas que caracterizam o mundo contemporâneo.

Competências e habilidades específicas:

- Interagir e agregar valor aos processos de geração, transferência e uso da informação, em todo e qualquer ambiente.

- Criticar, investigar, propor, planejar, executar e avaliar recursos e produtos de informação.

- Trabalhar com fontes de informação de qualquer natureza.

- Processar a informação registrada em diferentes tipos de suporte, mediante a aplicação de conhecimentos teóricos e práticos de coleta, processamento, armazenamento e difusão da informação. 
- Realizar pesquisas relativas a produtos, processamento, transferência e uso da informação.

O MEC ressalta que os conteúdos pragmáticos de caráter específico constituem o núcleo básico de formação dos bibliotecários e recomenda que os projetos acadêmicos enfatizem a adoção de uma perspectiva humanística na formulação dos conteúdos, dando-lhes sentido social e cultural (ibidem).

O bibliotecário de hoje deve desenvolver competências que variam de acordo com as metas e o grau de desenvolvimento do país. Espera-se desse profissional que ele esteja preparado para administrar, negociar e consolidar produtos de informação nas diferentes organizações, privadas e públicas, com um compromisso de liderança, além de atitude inovadora e criativa (Flores \& Vargas, 2007).

Conforme Carvalho (2008, p.17), "os bibliotecários devem atuar utilizando sua competência profissional no sentido de educar os usuários, para que estes desenvolvam as competências em informação”. Nesse sentido, Miranda (2004, p.119) aponta que: "Educar si próprio e educar os outros para a sociedade da informação é um dos grandes desafios para o profissional da informação, e um passo importante para a formação da cultura informacional na sociedade [brasileira]".

\section{A formação do bibliotecário e a competência informacional}

A competência informacional do bibliotecário deve-se dar ao longo de sua formação profissional, no desenvolvimento de conhecimentos, habilidades, atitudes, destrezas e comportamentos informacionais, tanto no aspecto pessoal quanto no profissional. De acordo com Vitorino (2008, p.6) "é na formação inicial e contínua do Profissional da Informação que a Competência Informacional pode tomar proporções nunca antes imaginadas”. 
Em geral, o bibliotecário possui uma formação acadêmica que lhe possibilita adquirir habilidades referentes aos processos informacionais de seleção, de busca, de avaliação, de disseminação e recuperação da informação, abrangendo as capacidades de pensamento crítico para analisá-las e para desenvolver projetos que visem à melhoria do ambiente profissional em que atua.

Nesse sentido, a competência informacional está relacionada a certas habilidades informacionais adquiridas geralmente no decorrer do curso de biblioteconomia, e também com o pensamento reflexivo, o aprender a aprender para oferecer-lhe condições de aprendizagem ao longo da vida e a busca por educação contínua no decorrer da carreira profissional. Considera-se que quanto maior a competência informacional do bibliotecário, "melhor sua atuação como ser social, e mais significativas as mudanças que o mesmo poderá incentivar como cidadão” (Lecardelli \& Prado, 2006, p.40).

Em relação à profissão, percebe-se que o "letramento informacional $^{1}$ também cria uma demanda de serviços de informação cada vez mais sofisticada e de alta qualidade, exigindo do profissional, além dos conhecimentos básicos, trabalho interdisciplinar, o uso do senso crítico para resolução de problemas informacionais" (Rocha et al., 2008).

A competência informacional, no entanto, precisa ser trabalhada de forma sistematizada no curso de biblioteconomia, tanto para a aquisição da competência informacional pelos futuros bibliotecários quanto para que adquiram condições de aplicar os programas de competência informacional nos seus locais de atuação. Ou seja, o bibliotecário precisa ser competente em informação para atingir suas metas como profissional e como indivíduo. Segundo Dudziak (2008, p.50), a competência informacional, "enquanto prática, precisa ser disseminada primariamente entre os profissionais da informação,

1 A competência em informação foi originalmente designada Information Literacy nos Estados Unidos. No Brasil foi traduzido como alfabetização informacional, letramento, literacia, fluência informacional e competência em informação (Dudziak, 2003), sendo o último mais difundido e utilizado. 
de modo que, a partir daí, possa atingir as práticas sociais, educacionais e de trabalho".

No que tange as competências do bibliotecário como agente educacional, algumas instituições desenvolveram parâmetros específicos para orientá-lo no desenvolvimento de suas funções em instituições de ensino. No Canadá, por exemplo, foram desenvolvidos padrões para os bibliotecários educadores, como atesta a obra Students' Information Literacy Needs in the 21st Century: Competencies for Teacher-Librarians (ATLC; CSLA, 1997), em razão das necessidades atuais de aprendizagem dos estudantes em relação aos recursos e às fontes de informação nas escolas.

Nas escolas canadenses, tem-se priorizado o desenvolvimento de programas de competência informacional. Chegou-se à conclusão, por meio de alguns estudos realizados no país, que as bibliotecas que criam programas instrucionais contribuem para o desenvolvimento de uma cultura escolar, e que, com esses programas e com um bibliotecário atuando juntamente com os professores no processo de ensino-aprendizagem, os alunos aprendem mais (ibidem).

Nos Estados Unidos, a ACRL (2007) elaborou um padrão mais específico para os bibliotecários referente às proficiências que eles devem possuir para serem bibliotecários instrutores e/ou coordenadores de programas de competência informacional. O documento foi intitulado Standards for proficiencies for instructions librarians and coordinators. A intenção é ajudar bibliotecários a definir e ter as habilidades necessárias para serem excelentes coordenadores em programas instrucionais.

O padrão possui diversos tipos de proficiência para que os bibliotecários possam atuar em todos os tipos de bibliotecas acadêmicas, desde as que servem os institutos tecnológicos até as que fazem parte das universidades. As proficiências foram organizadas em doze categorias:

1. Habilidades administrativas.

2. Habilidades de análise e avaliação. 
3. Habilidades de comunicação.

4. Conhecimento da estrutura curricular.

5. Habilidades de integração de competência informacional.

6. Habilidades de planejamentos instrucionais.

7. Habilidades de liderança.

8. Habilidades de planejamento.

9. Habilidades de apresentação.

10. Habilidades de promoção.

11. Especialista no assunto.

12. Habilidades de ensino.

Em geral, essas categorias direcionam para 41 proficiências essenciais para bibliotecários instrutores (responsáveis pela aplicação de atividades junto aos alunos sobre o universo informacional e seus processos) e 28 proficiências adicionais para bibliotecários coordenadores (responsáveis pelo planejamento, implementação e aplicação dos programas).

O padrão da ACRL (2007) é muito importante para a área de biblioteconomia e ciência da informação, pois evidencia a importância do bibliotecário possuir a competência informacional para atuar no desenvolvimento e aplicação dos programas instrucionais em bibliotecas. Ele direciona a busca pela educação contínua dos profissionais da informação, de modo a servir como guia no desenvolvimento de pesquisas sobre a formação e atuação do mesmo em relação à temática.

O profissional da informação tem um importante papel na disseminação, implementação e desenvolvimento dos programas de competência informacional. Assim, buscou-se apontar algumas questões sobre a necessidade do bibliotecário possuir uma formação que contemple a competência informacional, mostrando que o tema vem ganhando cada vez mais espaço de discussão na literatura da área, com apresentação de parâmetros que podem nortear a formação acadêmica do bibliotecário voltada para a competência informacional. 


\section{Considerações finais}

As transformações que estão ocorrendo no entorno social, político e econômico suscitaram diversas preocupações sobre a formação educacional dos indivíduos. No Ensino Superior, as escolas formadoras passaram a rediscutir aspectos voltados para a formação e atuação profissional, focando-se nas competências necessárias para viver em uma sociedade em constante mutação e pautada no uso intensivo da informação.

As questões referentes à formação do bibliotecário também vêm sendo rediscutidas, especialmente por ser a informação seu objeto de trabalho, abrindo-lhe novas oportunidades de atuação. Existe um complexo rol de competências que auxiliam no desenvolvimento profissional dos graduandos, como as competências básicas, genéricas e específicas. Essas competências são necessárias para o efetivo desenvolvimento e atuação do profissional bibliotecário, assim como as competências profissionais em informação e documentação, próprias de sua profissão.

Diante desse contexto, abre-se à biblioteconomia a possibilidade de ressaltar os aspectos sociais e educacionais da profissão, especialmente por meio da discussão da competência informacional. A competência informacional deve fazer parte do processo de construção da aprendizagem dos graduandos dos cursos de biblioteconomia, ressaltando habilidades inerentes à profissão em relação ao seu papel pedagógico e em relação ao universo informacional e seus processos, tais como seleção, busca, avaliação, disseminação, recuperação, e sobre os aspectos éticos e legais que rodeiam o uso da informação.

As escolas de biblioteconomia devem incluir na formação dos bibliotecários a questão da competência informacional, com a finalidade de formar estudantes aptos para atuar num ambiente de constantes transformações.

Conclui-se que a competência informacional carece de discussões maiores no contexto brasileiro, ressaltando-se a importância de que essa discussão se dê na formação dos bibliotecários. O bibliote- 
cário precisa, então, possuir uma formação que lhe certifique conhecimentos, habilidades, destrezas e atitudes relacionadas ao seu fazer profissional e conhecimentos de âmbito geral para poder lidar com a realidade do país e do mundo.

A competência informacional também ressalta os aspectos relacionados à responsabilidade social, nos quais abrange as funções do bibliotecário como profissional, de modo a colaborar para o desenvolvimento de aprendizes autônomos em relação ao universo informacional e seus processos, e, como cidadãos, aptos para tomarem decisões baseadas em critérios avaliativos informacionais, agregando valor ao aprendizado obtido na formação profissional/ educacional e na vida diária, de modo a colaborar para o progresso da sociedade.

Os bibliotecários e as bibliotecas têm muito a contribuir com a inserção de programas de competência em informação no Brasil, auxiliando na formação de indivíduos que saibam lidar com o universo informacional e seus processos, desenvolvendo o aprender a aprender e o aprendizado ao longo da vida.

\section{Referências}

ABELS, E. et al. Competencies for information professionals of the $21^{\text {st }}$ Century. Canadá: Special Libraries Association, 2003. Disponível em: <http://www.sla.org/content/learn/members/competencies/ index.cfm > Acesso em: 23 mar. 2009.

ALLENDEZ SULLIVAN, P. M. El impacto de las nuevas tecnologías en la competencia laboral del bibliotecario del siglo XXI. Biblios, Lima, v.5, n.17, jan./mar. 2004.

ASSOCIATION For Teacher-Librarianship In Canada; The Canadian School Library Association. Students' Information Literacy Needs in the 21st Century: Competencies for Teacher-Librarians. Canadá: Canadian Association for School Libraries, 1997. Disponível em: $<$ www.cla.ca/casl/literacyneeds.html>. Acesso em: 22 abr. 2009. ASSOCIATION OF COLLEGE AND RESEARCH LIBRARIES. Information Literacy competency for higher education. Chicago: 
ALA, 2000. Disponível em: <http://www.ala.org/acrl/ ilcomstan.html > Acesso em: 6 jan. 2007.

ASSOCIATION OF COLLEGE AND RESEARCH LIBRARIES. Standards for proficiencies for instruction librarians and coordinators. Chicago: ALA, 2007. Disponível em: <http:// www.ala.org/ala/mgrps/divs/acrl/standards/profstandards.cfm> Acesso em: 3 mar. 2009.

BRASIL. Ministério da Educação. Parecer n CNE/ CES 492/2001, de 4 jul. de 2001. Estabelece as Diretrizes Curriculares Nacionais dos cursos de Filosofia, História, Geografia, Serviço Social, Comunicação Social, Ciências Sociais, Letras, Biblioteconomia, Arquivologia e Museologia. Diário Oficial da União, Brasília, DF, 9 jul. 2001. Disponível em: <http://portal.mec.gov.br/cne/arquivos/ pdf/CES0492.pdf. >. Acesso em: 12 set. 2008.

CARVALHO, F. C. de. Educação e estudos de usuários em bibliotecas universitárias brasileiras: abordagem centrada nas competências em informação. Brasília, 2008. 146f. Dissertação (Mestrado) - Programa de Pós-Graduação em Ciência da Informação, Universidade de Brasília.

CAVALCANTE, L. E. Políticas de formação para a competência informacional: o papel das universidades. Revista Brasileira de Biblioteconomia e Documentação: Nova Série, São Paulo, v.2, n.2, p.47-62, dez. 2006.

DELORS, J. Educação: um tesouro a descobrir: relatório para a Unesco da Comissão Internacional sobre educação para o século XXI. São Paulo: Cortez; Brasília: MEC: Unesco, 1998.

DUDZIAK, E. A. Information literacy: princípios, filosofia e prática. Ciência da Informação, Brasília, v.32, n.1, p.23-35, jan./abr. 2003. . Os faróis da sociedade de informação: uma análise crítica sobre a situação da competência informacional no Brasil. Informação ĖSociedade: Estudos, João Pessoa, v.18, n.2, p.41-53, maio./ago. 2008

FLORES N. E.; VARGAS A. H. El bibliotecólogo como agente activo en el proceso de aprendizaje en la universidad del Pacífico. In: JORNADAS NACIONALES DE BIBLIOTECAS UNIVERSITARIAS: CONOCIMIENTO PARA INNOVAR, 3, 2007, Peru. Anais eletrônicos... Peru: Grupo de Bibliotecas Académicas Peruanas, 2007. Disponível em: <http://opac.univalle.edu.co/cgilib? 
hitno $=6 \&$ infile $=$ details. glu\&loid $=717705 \& \mathrm{rs}=121934>$. Acesso em: 17 mar. 2008.

LECARDELLI, J.; PRADO, N. S. Competência informacional no Brasil: um estudo bibliográfico no período de 2001 a 2005. Revista Brasileira de Biblioteconomia e Documentação: Nova Série, São Paulo, v.2, n.2, p.21-46, dez. 2006.

MIRANDA, S. V. Identificando competências informacionais. Ciência da Informação, Brasília, v.33, n.2, p.112-122, maio/ago. 2004.

ROCHA, C. da et al. Abordagens das revistas brasileiras de ciência da informação e Biblioteconomia a respeito do letramento informacional. Revista ACB, Florianópolis, v.13, n.1, p.145-58, jan./jun. 2008. SALAS LAMADRID, C. Alfabetización informacional en la educación básica: el concepto adaptado a realidade chilena. Serie Bibliotecología y Gestión de Información, Santiago, n.22, mar. 2008.

SILVA, W. C. Miséria da biblioteca escolar. 3.ed. São Paulo: Loyola, 2003.

TAKAHASHI, T. (Org.) Sociedade da informação no Brasil: livro verde. Brasília: Ministério da Ciência e Tecnologia, 2000.

TEJADA ARTIGAS, C. M.; TOBÓN TOBÓN, S. (Coord.) El diseño del plan docente en Información y Documentación acorde el Espacio Europeo de Educación Superior: un enfoque por competencias. Madrid: FCD/ Universidad Complutense de Madrid, 2006.

TETERYCS, T. Bibliotecário de referência como coadjuvante no desenvolvimento do pensamento crítico do discente de graduação. In: SEMINÁRIO NACIONAL DE BIBLIOTECAS UNIVERSITÁRIAS, 15., 2008, São Paulo. Anais eletrônicos... Disponível em: <http://www.sbu.unicamp.br/snbu2008/anais/site/pdfs/ 2609.pdf>. Acesso em: 15 dez. 2008.

VALENTIM, M. L. P. Atuação e perspectivas profissionais do profissional da informação. In: (Org.) O profissional da informação: formação, perfil e atuação profissional. São Paulo: Polis: 2000. p.135-52.

VITORINO, E. V. Competência informacional: princípios para a formação contínua de profissionais da informação em bibliotecas universitárias. In: SEMINÁRIO NACIONAL DE BIBLIOTECAS UNIVERSITÁRIAS, 15, 2008, São Paulo. Anais eletrônicos... Disponível em: <www.sbu.unicamp.br/snbu2008/anais/site/pdfs/ 2698.pdf>. Acesso em: 15 dez. 2008. 


\title{
15 \\ INFORMAÇÃO E CONHECIMENTO COMO ALICERCES PARA A GESTÃO ESTRATÉGICA EMPRESARIAL: UM ENFOQUE NOS FLUXOS E FONTES DE INFORMAÇÃO
}

\author{
Cíntia Gomes Pacheco \\ Marta Lígia Pomim Valentim
}

\section{Introdução}

O ambiente de negócios atua em um cenário globalizado, competitivo e amplamente influenciado pelas Tecnologias de Informação e Comunicação (TIC), implicando uma constante adaptação das empresas com relação às manifestações do macroambiente, quais sejam, políticas sociais, econômicas, tecnológicas, entre outras. A influência nas organizações reflete em como as pessoas se relacionam e as atividades que desenvolvem ante esse contexto externo empresarial.

Uma gestão proativa indica o conhecimento do ramo de negócio e também atenta para o ambiente externo que a envolve, tornandose importante a busca por uma atuação no mercado amparada por informação e conhecimento. Uma vez utilizados como alicerces para as atividades empresariais, dão vazão às possibilidades existentes de caminhos a serem seguidos e permitem um planejamento estratégico em que as decisões são tomadas com cautela visando o bom andamento do negócio.

A partir desse contexto, são apresentadas no presente capítulo reflexões acerca do uso de informação e de conhecimento no âmbito empresarial, bem como os fluxos internos e externos de informação 
presentes nesse ambiente, além das possibilidades de fontes de informação existentes que podem ser consultadas pelos gestores e as pessoas atuantes nas empresas. Esta abordagem objetiva contribuir para a reflexão sobre uma gestão estratégica pautada no uso consciente de informações para a tomada de decisão mais assertiva.

\section{Informação e conhecimento como alicerces da gestão empresarial contemporânea}

No âmbito empresarial, informação e conhecimento podem ser considerados alicerces de suma importância para a gestão estratégica, pois permeiam todas as atividades empresariais, permitindo às pessoas uma bagagem informativa que propicia melhor compreensão das manifestações do ambiente externo, que está se modificando constantemente, caracterizando-se como complexo e dinâmico. É necessário saber interpretar o macroambiente para que as mudanças externas não afetem as organizações de forma negativa e, dessa forma, possibilitem adaptações de acordo com o contexto.

Diante da discussão sobre informação e conhecimento no âmbito empresarial cabe uma ressalva, uma vez que grande parte das empresas possui dificuldades em compreender as relações entre esses termos. Davenport \& Prusak (1999) inferem conceitos de ordem mais elevada, quais sejam sabedoria (wisdom) e insight, para elucidar a relação entre os termos dados, informação e conhecimento.

Em relação ao termo dado, Davenport \& Prusak (1999) afirmam que todas as empresas necessitam de dados para terem uma dimensão de fatos distintos e objetivos que podem ser relativos a algum evento. São normalmente armazenados em meios tecnológicos, sendo gerenciados pelos setores de finanças, marketing e contabilidade. A grande quantidade de dados armazenados pode dificultar a identificação ou mesmo a extração de significado de dados que realmente importam e, além disso, não possuem significado inerente. 
Dados descrevem apenas parte daquilo que aconteceu; não fornecem julgamento, nem interpretação, nem nenhuma base sustentável para a tomada de ação. Embora a matéria-prima do processo decisório possa incluir dados, eles não podem dizer o que fazer. Dados nada dizem sobre a importância ou irrelevância. Porém, os dados são importantes para as organizações - em grande medida, certamente, porque são matériaprima essencial para a criação da informação. (ibidem, p.3)

No referente à informação, atrelam o termo à noção de "dar forma a” (ibidem, p.4), visando trazer alguma diferença para a pessoa que recebe a informação, ou seja, na própria perspectiva ou insight.

A informação é compreendida quando ela traz significado e também por meio de vários métodos:

- Contextualização: sabemos qual a finalidade dos dados coletados.

- Categorização: conhecemos as unidades de análise ou os componentes essenciais dos dados.

- Cálculo: os dados podem ser analisados matemática ou estatisticamente.

- Correção: os erros são eliminados dos dados.

- Condensação: os dados podem ser resumidos para uma forma mais concisa. (ibidem, p.5, grifo dos autores)

O conhecimento, por sua vez, é inerente ao ser humano, uma vez que pode expressar seu conhecimento por meio de registros ou da fala e relações de aprendizagem.

Conhecimento é uma mistura fluida de experiência condensada, valores, informação contextual e insight experimentado, a qual proporciona uma estrutura para a avaliação e incorporação de novas experiências e informações. Ele tem origem e é aplicado na mente dos conhecedores. Nas organizações, ele costuma estar embutido não só em documentos ou repositórios, mas também em rotinas, processos, práticas e normas organizacionais. (ibidem, p.6)

A partir das explanações de Davenport \& Prusak (1999), Clarke \& Rollo (2001, p.208) apresentam na Figura 1 a relação dos termos dado, informação, conhecimento, insight e sabedoria: 


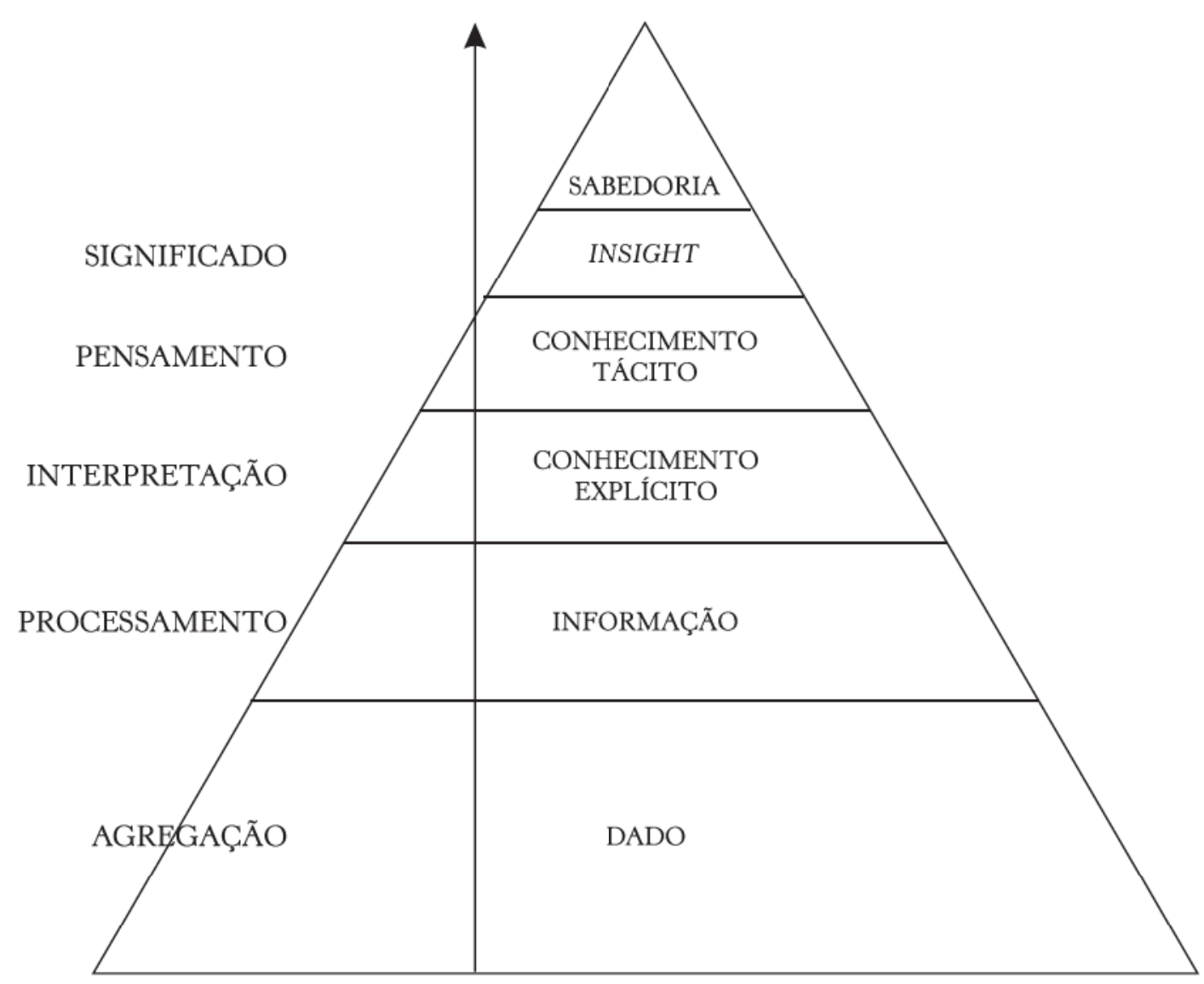

Figura 1 - Relação entre dado, informação, conhecimento, insight e sabedoria. Fonte Adaptada: Clarke \& Rollo (2001, p.208).

De acordo com a Figura 1, pode-se inferir que a partir de um conjunto de dados é possível separar os que possuem significado para uma determinada pessoa analisá-los e agregar valor; a partir dessa ação os dados podem se constituir em uma informação, que uma vez apropriada pela mente humana pode gerar um "novo" conhecimento que, por sua vez, pode promover um insight e, consequentemente, um saber. Contudo, a relação entre os termos não necessariamente ocorre dessa forma, pois cada indivíduo possui suas próprias experiências e pode desenvolver esse processo de forma diferente.

Por exemplo, na empresa, quando um especialista em algum tema é consultado para resolver determinado problema ou trazer uma nova perspectiva para os negócios, ele usará sua própria experiência profissional e de vida para compreender o que está acontecendo, po- 
dendo fazer inter-relações com a situação presente utilizando situações passadas.

Nessa perspectiva, Choo (2003) apresenta uma discussão acerca da relação entre as organizações e o ambiente externo visando ao uso da informação para a tomada de decisão. $\mathrm{O}$ autor contextualiza a informação sob o ponto de vista do comportamento humano, o qual envolve três dimensões psíquicas: cognitiva, emocional e situacional. $\mathrm{O}$ mesmo autor analisa os ambientes informacionais no âmbito empresarial, o qual é composto de pessoas, e, portanto, as dimensões citadas permeiam esse ambiente. Entretanto, em razão do caráter sociocultural de cada pessoa, geralmente apenas uma das dimensões se sobressai, fator que pode acarretar desequilíbrio no processo de decisão.

O autor propõe em complemento à tríade a discussão do uso da informação em um contexto holístico, analisando e comparando as principais formas pelas quais as empresas usam a informação estrategicamente, de maneira que tenham sentido e que promovam uma mudança no ambiente empresarial. Portanto, são examinadas a estrutura e a dinâmica da informação em três perspectivas:

- Criação de significado, por meio da identificação dos acontecimentos que permeiam o ambiente no sentido de desenvolver uma interpretação desses acontecimentos para melhor compreender a situação, visando a um direcionamento para uma ação, uma decisão.

- Construção de conhecimento, relação dos conhecimentos tácito e explícito, visando à criação de mais conhecimentos.

- Tomada de decisão, pela criação de significados e da construção de conhecimento é possível direcionar as possíveis alternativas para tomar decisões.

É importante ressaltar que as três arenas de uso da informaçãocriar significado, construir conhecimento e tomar decisões - são entendidas como processos interligados, em que as atividades são alimentadas mutuamente caracterizando-se como uma visão holística.

Essa é a perspectiva da organização do conhecimento, a qual possui informações e conhecimento como insumos que conferem van- 
tagem competitiva, permitindo agir com inteligência, discernimento e criatividade no ambiente dinâmico. Nesse sentido, a atuação da empresa confere uma maior compreensão do ambiente em que está inserida, sendo capaz de:

- adaptar-se às mudanças do ambiente no momento adequado e de maneira eficaz;

- empenhar-se na aprendizagem constante, o que inclui desaprender pressupostos, normas e crenças que perderam validade;

- mobilizar o conhecimento e a experiência de seus membros para gerar inovação e criatividade;

- focalizar seu conhecimento em ações racionais e decisivas. (Choo, 2003, p.32)

A abordagem holística também é conhecida como ecologia da informação, de acordo com Davenport \& Prusak (1998), ela enfoca além do ambiente informacional de uma empresa, propondo uma visão ampla do ambiente organizacional em que, por meio dela, é possível realizar uma análise de espaços físicos, tipo de tecnologia empregada, situação dos negócios e avaliação do ambiente externo.

As empresas, para se manterem no mercado altamente competitivo, necessitam ser bem informadas sobre tudo o que acontece ao seu redor, ou seja, as necessidades dos consumidores, as estratégias dos concorrentes, as regulamentações governamentais etc. Portanto, uma ampla gama do volume informacional de uma empresa refere-se ao ambiente externo dos negócios (Davenport \& Prusak, 1998).

Na próxima seção serão apresentadas reflexões acerca do uso de informações pelo ambiente empresarial, enfocando os fluxos e fontes de informação. 


\section{Possibilidades de informação para o ambiente empresarial: uma reflexão acerca dos fluxos e fontes de informação}

As empresas são formadas por diferentes ambientes e fluxos informacionais, os quais permitem uma visualização geral de sua estrutura, bem como de suas necessidades informacionais. A partir do reconhecimento dos diferentes ambientes empresariais, é possível identificar os fluxos formais e informais de informação, que são utilizados nos processos, atividades e tarefas desenvolvidas neste âmbito.

Osfluxos formais atuam na estrutura física da empresa, ou seja, é relacionada ao próprio organograma, em que ocorrem inter-relações entre os setores; os fluxos informais são constituídos a partir da relação entre as pessoas das diferentes áreas/setores da organização. Ambos os fluxos de informação são subsidiados pelos insumos dados, informação e conhecimento, contribuindo para a constituição dos ambientes informacionais (Valentim, 2002).

O ambiente empresarial é contemplado por uma vasta gama e variedade de informações, as quais visam atender às necessidades informacionais das pessoas que compõem esse cenário.

Essa compreensão pode ser visualizada por meio das diferentes manifestações da informação nesse meio, ou seja, como os gestores usam a informação para o negócio. São apresentadas na Figura 2 as considerações de Kaye (1995a, p.15) a respeito da importância da informação no âmbito empresarial. O autor apresenta a maneira pela qual os gestores usam a informação por meio de tipologia, processo e uso da informação.

Para Kaye (1995a), os tipos de informação variam e podem ser desde dados quantitativos, fatos, relatórios, até uma argumentação, discussão etc. A informação como processo revela quais os tipos de tratamento ela pode ser submetida de acordo com a situação/contexto. $\mathrm{O}$ uso da informação confere a finalidade à qual ela pode ser submetida, não se limitando às formas positivas e óbvias como formas de aprendizagem e compreensão, resolução de problemas etc., 
mas podendo também ser usada como meio de infringir regras, manipular pessoas e situações.

Tipologia da informação Informação como

Uso da informação processo

- Dados numéricos e seus derivados

- Conhecimento de fatos

- Instruções e comandos

- Requisições, ordens e pedidos

- Relatórios e contas

- Códigos e orientações

- Narrativas e descrições

- Publicidade, relações públicas e publicidade

- Pareceres e interpretações

- Avaliações e críticas

- Argumentos, debates e discussões
- Gravação, depósito e armazenagem

- Edição e publicação

- Cópia, reprografia e impressão

- Tabulação

- Colação

- Análise e interpretação

- Crítica e avaliação

- Classificação, catalogação e indexação

- Resumos

- Recuperação

- Comunicação, divulgação e distribuição

- Custos e valorização

- Restrição

- Descarte

- Corrupçãoe falsificação

- Roubo, desvio

- Proteção, copyright
- Aprendizagem e compreensão

- Ensino, instrução e formação

- Descoberta e invenção

- Resolução de problemas

- Tomada de decisão e escolha

- Ação informada e funcionamento

- Justificativa, explicação e contabilidade

- Vendas e marketing

- Criação de imagem

- Convencimento, influência e manipulação

- Dominação e subordinação

- Engano e traição

Figura 2 - Manifestações da informação: tipo, processo e uso. Fonte Adaptada: Kaye (1995a).

A natureza dos dados, informação e conhecimento que permeiam o ambiente empresarial foi contextualizada por Valentim (2002) em três tipos: estruturados - os termos já se encontram sistematizados, com tratamento, e estão disponíveis para acesso interno ou externo à empresa; estruturáveis - produzidos nos diversos setores da empresa, porém sem tratamento; não estruturados - produzidos fora da empresa, não possuem identificação e nenhum tratamento.

Com relação às origens, esses insumos podem provir de fontes formais e informais. As fontes formais podem ser encontradas em bases de dados, informações científicas e técnicas, além de outros 
documentos, em que se caracteriza a formalidade das informações e seu registro em um suporte físico; ao passo que as fontes informais podem ser encontradas em seminários, congressos, visitas aos clientes e fornecedores, exposições e feiras etc., em que as informações não estão registradas em um dado suporte físico (Beal, 2004).

O uso de fontes de informação está atrelado às necessidades de informação das pessoas e podem ser classificadas de acordo com o formato, o status ou a localização. Nesse sentido, são apresentados na Figura 3 os tipos de fontes de informação baseados nas considerações de Kaye (1995b):

\begin{tabular}{ll}
\hline Classificação & Exemplos \\
\hline \multirow{2}{*}{ Formato } & $\cdot$ Oral ou documentada \\
& $\cdot$ Textual ou audiovisual/multimídia \\
& $\cdot$ Livros ou bases de dados eletrônicas \\
\hline & $\cdot$ Pessoal ou impessoal \\
& $\cdot$ Formal ou informal \\
& $\cdot$ Publicada ou não publicada \\
Status & $\cdot$ Confidencial \\
\hline Localização & $\cdot$ Interna ou externa \\
\hline
\end{tabular}

Figura 3 - Classificação das fontes de informação.

Fonte Adaptada: Kaye (1995b).

Cada termo já pressupõe o seu significado. No entanto, ressaltese que, no âmbito empresarial, fontes pessoais podem ser consideradas pessoas que fornecem informações aos gestores, incluem colegas da organização, superiores e/ou subordinados e, no ambiente externo, profissionais e outros contatos. Fontes impessoais incluem consultas às publicações, tais como livros, jornais, revistas, rádio e televisão da organização, relatório anual e contas e conteúdos da Internet. Podem, ainda, ser diferenciadas pelo tratamento recebido, ou seja, se estão formalizadas, regularizadas ou não. Outra ressalva é que fontes formais são frequentemente também impessoais e fon- 
tes informais são frequentemente pessoais, ou seja, um gestor pode consultar algum especialista em determinado assunto, sendo o especialista, neste caso, uma fonte de informação formal pessoal (Kaye, 1995b).

A fonte de informação será usada se o beneficiário, por exemplo, um gestor, considerá-la relevante, oportuna e precisa para dada situação. Essa avaliação de relevância cabe à percepção e confiabilidade do gestor/beneficiário acerca da fonte de informação e também do estado, do formato e da localização da fonte.

Quanto à análise da qualidade da informação, De Sordi (2008, p.59) apresenta a Figura 4.

Essas perguntas podem ser consideradas fundamentais para o processo de análise da qualidade da informação. Os gestores da informação podem se pautar por elas para analisar as situações críticas ao negócio, considerando as particularidades de cada informação analisada, sendo, entretanto, necessário o aprimoramento contínuo das questões (De Sordi, 2008).

De acordo com Kaye (1995b), diversas pesquisas acerca do uso de fontes no âmbito empresarial apontam que os gerentes e usuários da informação preferem fontes pessoais e contatos informais. A consulta de uma informação por intermédio das pessoas permite muito além de dados, pois possibilita um aconselhamento, um incentivo, um apoio, e pode também avaliar as informações fornecidas e indicar a melhor opção quando há possibilidades de escolhas.

$\mathrm{O}$ autor ainda revela que o próprio gerente da empresa pode ser consultado, pois se constitui em uma das principais fontes de informação, porquanto é considerado uma fonte de conhecimentos e competências. Contudo, vale lembrar que muitos gestores não olham além dos limites do ambiente empresarial, podendo ser prejudicial aos negócios.

Nesse sentido, Kaye (1995b) apresenta uma visão geral da diversidade de fontes de informação que podem ser usadas pelos gestores. O autor separa em quatro quadrantes visando à apreensão da totalidade complexa da rede de fontes, as quais são apresentadas na Figura 5 a seguir. 


\begin{tabular}{|c|c|}
\hline $\begin{array}{l}\text { Dimensão da } \\
\text { informação }\end{array}$ & Aspecto principal a ser analisado \\
\hline Abrangência/ escopo & $\begin{array}{l}\text { A informação que o público-alvo necessita } \\
\text { está completa e somente ela, ou seja, sem } \\
\text { excessos desnecessários? }\end{array}$ \\
\hline Integridade & $\begin{array}{l}\text { A informação presente está íntegra, inteira, } \\
\text { ou está corrompida, adulterada? }\end{array}$ \\
\hline Acurácia/veracidade & $\begin{array}{l}\text { A informação pode ser considerada fiel aos } \\
\text { fatos que ela representa? }\end{array}$ \\
\hline $\begin{array}{l}\text { Confidencialidade/ } \\
\text { privacidade }\end{array}$ & $\begin{array}{l}\text { A informação é acessada somente por quem } \\
\text { de direito? }\end{array}$ \\
\hline Disponibilidade & $\begin{array}{l}\text { A informação é facilmente acessada por } \\
\text { quem de direito? }\end{array}$ \\
\hline Atualidade & $\begin{array}{l}\text { A informação é constantemente } \\
\text { gerada/atualizada nos intervalos de tempo } \\
\text { considerados adequados pelo público-alvo? }\end{array}$ \\
\hline Ineditismo/raridade & $\begin{array}{l}\text { Trata -se de uma informação de difícil } \\
\text { obtenção do ponto de vista de ser rara ou } \\
\text { escassa? }\end{array}$ \\
\hline Contextualização & $\begin{array}{l}\text { A informação é atraente ao público ao } \\
\text { público-alvo? }\end{array}$ \\
\hline Precisão & $\begin{array}{l}\text { A informação está suficientemente } \\
\text { detalhada/ esmiuçada para o pronto uso? }\end{array}$ \\
\hline Confiabilidade & $\begin{array}{l}\text { A fonte e o conteúdo da informação têm } \\
\text { credibilidade perante o público-alvo? }\end{array}$ \\
\hline Originalidade & $\begin{array}{l}\text { A informação original, ou seja, a informação } \\
\text { com que se trabalha provém diretamente da } \\
\text { fonte geradora ou de algum retransmissor } \\
\text { que a traduziu, copiou, editou ou realizou } \\
\text { alguma outra atividade que possa ter } \\
\text { alterado seu conteúdo original? }\end{array}$ \\
\hline Existência & $\begin{array}{l}\text { Em quantas mentes, locais físicos e virtuais } \\
\text { a informação está disponível? }\end{array}$ \\
\hline $\begin{array}{l}\text { Pertinência/agregação } \\
\text { de valor }\end{array}$ & $\begin{array}{l}\text { O quanto a informação é importante ao } \\
\text { público-alvo no tempo presente? }\end{array}$ \\
\hline Identidade & $\begin{array}{l}\text { A denominação da informação é } \\
\text { representativa, pertinente e fiel no que tange } \\
\text { ao seu conteúdo? }\end{array}$ \\
\hline Audiência & $\begin{array}{l}\text { A informação está sendo acessada pelo seu } \\
\text { público-alvo? }\end{array}$ \\
\hline
\end{tabular}

Fonte: De Sordi (2008, p. 59). 


\begin{tabular}{|c|c|c|}
\hline Fontes & Informais & Formais \\
\hline 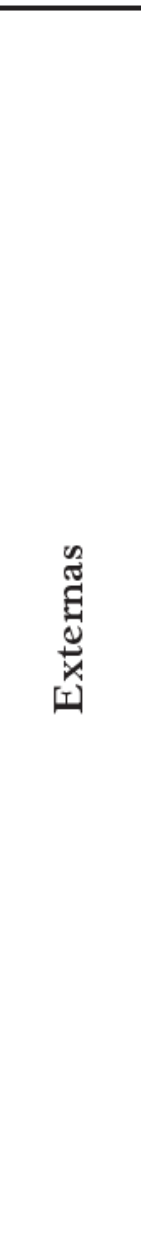 & $\begin{array}{ll} & \text { Quadrante A } \\
\text { - } & \text { Comércio; } \\
\text { - } & \text { Contatos } \\
\text { personalizados com } \\
\text { conselheiros } \\
\text { (financeira, jurídica } \\
\text { etc.); } \\
\text { - Profissionais } \\
\text { associados; } \\
\text { Contatos sociais e } \\
\text { familiares. }\end{array}$ & 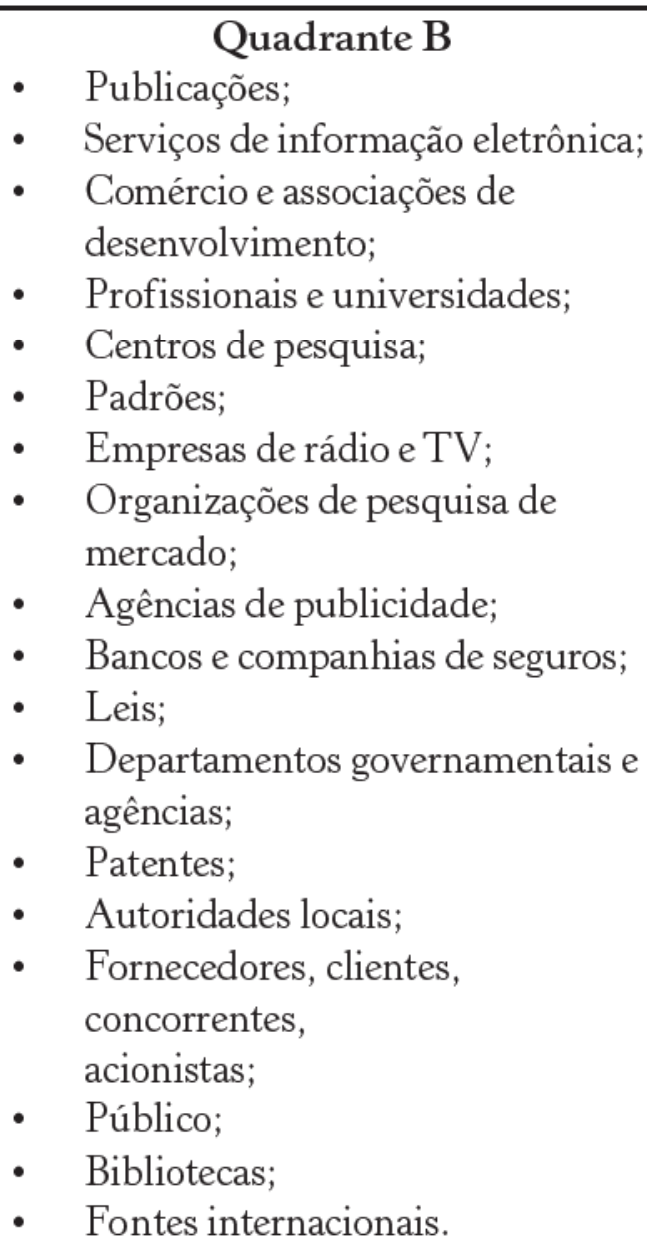 \\
\hline & 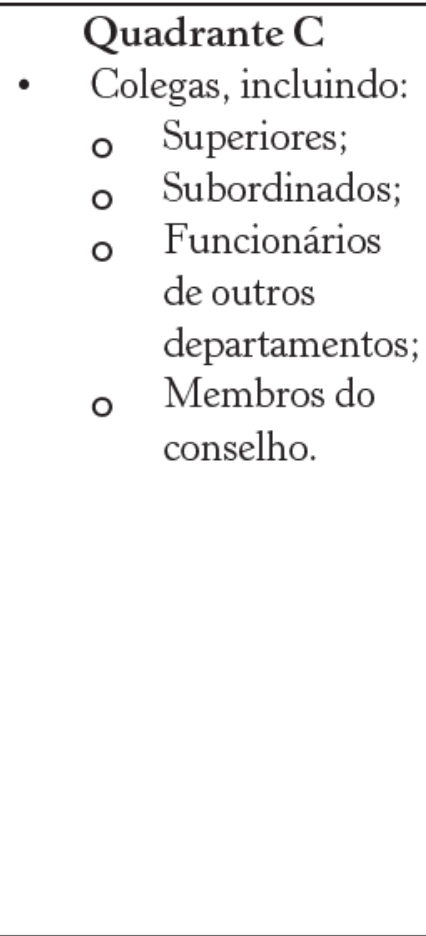 & \begin{tabular}{ll} 
& \multicolumn{1}{c}{ Quadrante D } \\
- & Relatórios; \\
- & Memorandos; \\
- & Instruções de trabalho; \\
- & Orçamento, contas; \\
- & Ordens e requisições; \\
- & Faturas; \\
- & Notas; \\
- & Resultados de análises e testes; \\
- & Gestão de sistemas de informação \\
& / decisão \\
& sistemas de apoio à decisão / \\
- & sistemas de informação executiva; \\
- & Sistemas especialistas; \\
- & Departamentos e unidades \\
& organizacionais.
\end{tabular} \\
\hline
\end{tabular}

Figura 5 - Quadrantes das fontes de informação no universo empresarial. Fonte Adaptada: Kaye (1995b). 
Diante da vasta quantidade e variedade de informações que contemplam o universo empresarial, Valentim (2006, p.13-14, grifo nosso) relaciona os tipos de informações que atendem às necessidades informacionais das pessoas no âmbito organizacional:

a) Informação estratégica, que apoia o processo de tomada de decisão e possibilita à alta administração da organização definir e planejar as estratégias de ação de médio e longo prazos.

b) Informação voltada ao negócio, que possibilita ao nível tático da organização definir ações de curto prazo, bem como observar oportunidades e ameaças para o negócio corporativo.

c) Informação financeira, que apoia as atividades desenvolvidas pelos profissionais da área financeira para que processem estudos de custos, lucros, riscos e controles.

d) Informação comercial, que subsidia as pessoas da área comercial nos processos relacionados à exportação e/ou importação de materiais, produtos e serviços; que subsidia também as pessoas da área jurídica no que diz respeito à legislação do país no qual se estabelece determinada transação comercial.

e) Informação estatística, que subsidia várias áreas da organização, por meio de séries históricas, estudos comparativos, apresentando percentuais e/ou números relacionados ao negócio da organização.

f) Informação sobre gestão, que atende às necessidades dos gerentes e executivos da organização no planejamento e gerenciamento de projetos, na gestão de pessoas etc.

g) Informação tecnológica, que tanto subsidia as pessoas da área de pesquisa e desenvolvimento $(\mathrm{P} \& \mathrm{D})$ na criação e no desenvolvimento de produtos, materiais e processos, por meio do monitoramento da concorrência referente às inovações de produtos, materiais e processos, como apoia a implantação dos sistemas de qualidade no ambiente organizacional.

h) Informação geral, que subsidia todas as áreas da organização, possibilitando aos profissionais, que nela atuam, atualização constante.

i) Informação "cinzenta" de qualquer natureza, para qualquer área e com qualquer finalidade de uso; esse tipo de informação não é detectado em buscas formais, podendo-se citar, como exemplo, colégio invisível, documentos confidenciais em difícil acesso, redes de relacionamento etc. 
O conhecimento pelas empresas desses tipos informacionais contribui para que elas compreendam suas atividades, além de identificar o tipo de informação e o tratamento necessário, a fim de garantir um recurso competitivo. Faz-se importante a compreensão da dimensão dos tipos de fontes de informação nesse âmbito para propiciar uma maior consistência informativa.

Os estudos relativos a fontes de informação no contexto empresarial demonstram que as fontes de informação são basicamente classificadas como fontes externas (formais e informais) e fontes internas (formais e informais), como já mencionadas no decorrer deste capítulo.

Suzana Mueller (2000) destaca o conhecimento que pode ser obtido a partir de pesquisas científicas, enfatizando a confiabilidade como uma característica importante da ciência, pois prevê uma rigorosa metodologia científica para a construção de conhecimento e, além disso, é de suma importância que os resultados obtidos por meio da pesquisa sejam submetidos à avaliação por outros cientistas e divulgados para apreciação. A divulgação e a avaliação pressupõem confiança nos resultados e, nesse sentido, existe um amplo sistema de comunicação, compreendendo canais formais e canais informais, os quais são usados tanto para divulgar os resultados quanto para conhecer outros trabalhos realizados por outros pesquisadores. De acordo com a autora, as publicações geradas a partir das pesquisas variam no formato, como relatórios, artigos, livros, entre outros, no suporte, como papel, meio eletrônico etc., audiências, ou seja, estudantes, colegas, e função, ou seja, informar, registrar autorias, obter reações, entre outras.

Os documentos gerados podem ser classificados como primários, secundários ou terciários. ${ }^{1}$ Os documentos ou fontes primárias "são geralmente produzidos com interferência direta do autor da pesquisa” (ibidem, p.31). São os relatórios técnicos, os trabalhos

1 Existem alguns autores que consideram a existência de apenas dois tipos de fontes, ou seja, fontes primárias (literatura propriamente dita) e fontes secundárias (serviços bibliográficos) (Mueller, 2000). 
apresentados em congressos, as teses e as dissertações, as patentes, as normas técnicas e os artigos científicos. Para Grogan (1992 apud Mueller, 2000, p.31)

As fontes primárias, por sua natureza, são dispersas e desorganizadas do ponto de vista da produção, divulgação e controle. Registram informações que estão sendo lançadas, no momento de sua publicação, no corpo de conhecimento científico e tecnológico. As fontes primárias são, por essas razões, difíceis de serem identificadas e localizadas.

No âmbito empresarial as fontes primárias podem ser consultadas para o entendimento do que está sendo tratado no escopo das pesquisas científicas, mediante consultas às pesquisas realizadas, por meio da leitura de artigos científicos, teses e dissertações, relatórios técnicos, normas e padrões, patentes, entre outras fontes, a fim de direcionar as atividades empresariais de acordo com as manifestações do macroambiente.

Discute-se muito sobre a interação universidade-empresa, que pode propiciar a integração das pesquisas científicas com as empresas, visto que se observa um distanciamento no que diz respeito às reflexões teóricas e a prática.

Entendemos que encontros científicos, por exemplo, contribuem, por meio de conversas informais, para discussões intelectuais que podem direcionar o desenvolvimento de pesquisas. As empresas, ao participarem desses eventos, também podem refletir efetivamente sobre sua prática.

Os documentos ou fontes secundárias "apresentam a informação filtrada e organizada de acordo com um arranjo definido, dependendo de sua finalidade" (Mueller, 2000, p.31). São as enciclopédias, os dicionários, os manuais, as tabelas, as revisões de literatura, os tratados, certas monografias e livros-texto, anuários e outros.

As empresas podem consultar fontes secundárias para diversas finalidades, a fim de buscar informações importantes que são necessárias em um determinado momento. Essas fontes são utilizadas para consultas às fontes primárias, visto que elas organizam estas fontes. 
Os documentos terciários são aqueles "que têm função de guiar o usuário para as fontes primárias e secundárias” (ibidem). São as bibliografias, os serviços de indexação e resumos, os catálogos coletivos, os guias de literatura, os diretórios e outros.

As empresas podem consultar fontes terciárias para localizar fontes primárias e secundárias, visto que elas não abarcam o conteúdo informacional necessário, mas apenas oferecem subsídios para encontrar as demais fontes. Se bem elaboradas, as fontes terciárias podem ser bons instrumentos de consulta para fins de suprir algumas das necessidades informacionais empresariais. Desse modo, destaca-se o guia de fontes de informação, que pode ser utilizado pela empresa como um instrumento de consulta constante, pois é elaborado de acordo com os objetivos e necessidades relacionados ao negócio, ou seja, é um instrumento seletivo voltado para um determinado público, e contempla os mais variados tipos de fontes de informação.

Compreender os tipos de fontes de informação, tanto formais quanto informais, permite às empresas um entendimento da função e abrangência dos materiais existentes internos à organização e as possibilidades de fontes que podem ser consultadas externamente.

Em suma, a categorização das fontes de informação permite compreender a dimensão de cada uma diante de sua função, ou seja, as fontes primárias exprimem a interferência direta do autor; as fontes secundárias facilitam o uso do conhecimento das fontes primárias, uma vez que existe um tratamento diferenciado para as mesmas de acordo com sua função e arranjo; e as fontes terciárias possibilitam que as fontes primárias e secundárias sejam encontradas.

As organizações são também consideradas fontes de informação, pois conforme afirma Campello (2000, p.35) "constituem um ponto de convergência da sociedade, pois geram empregos, desenvolvem tecnologia e atraem investimentos". Elas precisam estar constantemente vinculadas a outras organizações para se manterem e sobreviverem no mercado.

Existem diferentes tipos de organizações que variam de acordo com seu papel na sociedade, ou seja, existem organizações educa- 
cionais e de pesquisa, governamentais, profissionais e sociedades científicas, internacionais, organizações não governamentais (ONG), comerciais, entre outras (ibidem).

A autora afirma que as informações nas organizações podem ser acessadas por intermédio das pessoas vinculadas a elas ou de documentos que geram, assim como já mencionado no decorrer deste capítulo. A identificação de organizações pode ser feita por meio de diretórios, os quais listam os nomes das organizações fornecendo informações gerais como "endereço, telefone, fax, e-mail, produtos e serviços, nomes e cargos dos dirigentes e outras do gênero" (ibidem, p.38).

Existem, ainda, empresas especializadas na produção de diretórios, as quais armazenam informações sobre empresas em bases de dados onde são divulgadas e disponibilizadas pela Internet (ibidem). A autora ressalta que a fonte mais adequada para buscas sobre organizações é a Internet por meio do próprio site da empresa. Portanto, é imprescindível que as informações disponíveis no site sobre a empresa estejam atualizadas, assegurando informações consistentes.

É importante ressaltar que a busca por informações e fontes de informação pela Internet deve ser cuidadosamente refletida, porquanto é disponibilizada uma vasta quantidade e variedade de informações, produzidas por quaisquer pessoas ou instituições. Nesse contexto, existe a problemática da confiabilidade e consistência, visto que nesse emaranhado de informações só poderão ser consideradas as informações que fizerem sentido para alguém, a partir de uma avaliação prévia que estará relacionada a um contexto.

Em relação às fontes de referência na rede Internet, Tomaél et al. (2004) propõem dez critérios visando subsidiar a avaliação de fontes, os quais são apresentados na Figura 6. Vale mencionar que os critérios se constituem no resultado de aprimoramento e ajuste dos critérios preliminares desenvolvidos por Tomaél et al. (1999). 
Critérios de Avaliação

Diretrizes

Informações de identificação: dados detalhados da pessoa jurídica ou física responsável pelo site de forma a identificá-la plenamente.

- Endereço eletrônico (URL) do site e da fonte de informação, definindo de forma clara e objetiva a autoria.

- E-mail do site (organização que disponibiliza a fonte) diferente do $e$-mail da fonte de informação.

- Título da fonte de informação claro e preciso, além de informativo.

- Endereço eletrônico (URL) da fonte de informação definindo clara e objetivamente a autoria.

- Objetivos da fonte informando a que público destina-se.

- Disponibilidade de informações adequadas sobre a fonte (apresentação, nota explicativa, informações gerais etc.), descrevendo seu âmbito.

- Identificação da tipologia da fonte e de sua origem, no caso de tratar-se de evolução de formato impresso.

Consistência das informações:

detalhamento e completeza das informações que fornecem.

- Cobertura da fonte, abrangendo informações de toda a área que se propõe.

- Validez do conteúdo, isto é, sua utilidade em relação aos propósitos do usuário final.

- Resumos ou informações complementares como elementos que realmente contribuam para a qualidade.

- Coerência na apresentação do conteúdo informacional; a fonte não pode ser "carregada" a ponto de prejudicar sua consistência ou, ao contrário, apenas apresentar informações muito superficiais.

- Ofertas de informações filtradas ou com agregação de valor. Nesse caso, identificar se a informação oferecida é embasada ou somente opinativa.

- Apresentação de informação original ou apenas fornecimento do endereço para recuperá-la (baseada somente em acesso a links).

Confiabilidade das informações: investiga a autoridade ou responsabilidade.
- Dados completos de autoria como mantenedor da fonte, podendo ser pessoa física ou jurídica.

- Autor, pessoa física, reconhecido em sua área de atuação, demonstrando formação/especialização.

- Organização que disponibiliza o site, caso o autor da fonte pertença a ela.

- Conteúdo informacional relacionado à área de atuação do autor que demonstra relevância. 
- Observância de outras informações como: existência de referências bibliográficas dos trabalhos do autor; endereço para contato com o autor; se foi derivada de um formato impresso/ origem.

- Verificação de datas: quando foi produzida; se está atualizada e quando.

Adequação da fonte: tipo de linguagem utilizada e coerência com os objetivos propostos.
- Coerência da linguagem utilizada pela fonte com os seus objetivos e o público a que se destina.

- Coerência do site onde a fonte estiver localizada com seu propósito ou assunto.
Links internos: recursos que complementam as informações da fonte e permitem o acesso às informações e a navegação na própria fonte de informação.
- Clareza para onde conduzem.

- Tipos disponíveis: anexos, ilustrações, informações complementares, outras páginas do site.

- Atualização dos links, apontando para páginas ativas.
Links externos: recursos que permitem $\mathrm{o}$ acesso às informações e a navegação em outras fontes/sites.
- Clareza para onde conduzem.

- Devem apontar apenas para sites com informações fidedignas, úteis e apropriadas.

- Tipos disponíveis mais comuns: informações complementares e/ou similares, ilustrações, comércio relacionado, portais temáticos, entre outros.

- Revisão constante dos links, apontando para páginas existentes.

Facilidade de uso: facilidade para explorar/navegar no documento.
- Links que possibilitem fácil movimentação página a página, item a item, sem que o usuário perca-se ou confunda-se; links suficientes na fonte, que permitam avançar e retroceder.

- Quantidade de cliques para acessar a fonte e a informação:

- da página inicial do site até a fonte: recomendável três cliques;

- da fonte à informação: recomendável três ou menos cliques.

- Disponibilidade de recursos de pesquisa na fonte:

- função de busca;

- lógica booleana;

- índice;

- arranjo;

- outros. 
- Recursos auxiliares à pesquisa:

- tesauros, listas, glossários, mapa do site/ fonte, guia, ajuda na pesquisa, outros;

- instruções de uso;

- documentação/manuais da fonte de informação para download ou impressão.

Layout da fonte: mídias utilizadas.

- As mídias utilizadas devem ser interessantes.

- Tipos de mídias utilizadas: imagens fixas ou em movimento e som.

- A harmonia entre a quantidade de mídias utilizadas nos verbetes ou itens (partes) da fonte é fundamental.

- Coerência entre as várias mídias (texto x som x imagem):

- imagens com a função de complementar ou substituir conteúdos e não meramente ilustrar;

- pertinência com os propósitos da fonte;

- legibilidade (nitidez, tamanho da letra/ imagem);

- clara identificação das imagens.

- Na estrutura/apresentação da fonte (layout e arranjo) é importante que:

- haja coerência na utilização de padrões, estéticas da página, tamanho da letra, cor;

- os recursos, como a animação, sirvam a um propósito e não sejam apenas decorativos;

- as imagens facilitem a navegação e não a dificultem;

- design do menu seja estruturado para facilitar a busca da informação;

- a criatividade no uso dos elementos incluídos na página web contribua para a qualidade;

- evite-se o frame, que limita o uso da fonte (espaço de visualização).

Restrições percebidas: são situações que ocorrem durante o acesso e que podem restringir ou desestimular o uso da informação.
- Pequena quantidade de acessos simultâneos permitida.

- Alto custo de acesso à fonte de informação.

- Mensagens de erro durante a navegação.

- Direitos autorais impedindo o acesso à informação completa. 
Suporte ao usuário: elementos que fornecem auxílio aos usuários que são importantes no uso da fonte.
- Contatos com o produtor da fonte: endereços ou e-mail.

- Informações de ajuda na interface: Help.
Outras observações percebidas.
- Recursos que auxiliam o deficiente no uso da fonte.

- Opção de consulta em outras línguas.

Figura 6 - Critérios e diretrizes para avaliação de fontes de informação na Internet. Fonte Adaptada: Tomaél et al. (2000).

A definição de critérios para avaliar fontes de informação na Internet deve ser refletida constantemente, uma vez que as informações, os ambientes digitais e as tecnologias estão sempre se modificando e são afetados pelas inovações, atualizações, novas possibilidades de acesso e uso, bem como estão em constante aperfeiçoamento para melhor atender às expectativas de um mundo globalizado.

\section{Considerações finais}

Confere-se que, para atuar nesse cenário de mudanças, as empresas precisam atentar para a importância da informação e do conhecimento como um recurso gerencial estratégico a partir do reconhecimento de fontes de informação para suprir necessidades informacionais e ampliar as possibilidades de perceber informação, além também de se manterem atualizadas. Reconhecer os fluxos formais e informais permite uma visão geral de como é constituída a empresa.

As fontes de informação podem provir de fontes formais e/ou informais. O uso de fontes de informação pelas pessoas está atrelado às necessidades informacionais levantadas pelas mesmas, levando à busca de informações por meio das possibilidades de fontes a serem consultadas. 
Destaca-se a importância de se buscar por fontes de informação confiáveis diante do emaranhado de informações existentes disponibilizadas, sobretudo, na Internet.

Ressaltam-se as possibilidades de informação para o âmbito empresarial, que podem e devem ser utilizadas pelos gestores e pelos membros das organizações.

Esse reconhecimento garante um melhor aproveitamento das atividades empresariais pelos membros da organização, um planejamento estratégico em curto, médio e longo prazos, decisões mais assertivas no sentido de agir com apoio em fontes de informação relacionadas ao negócio, permitindo uma bagagem e consistência informativa para melhor direcionar o andamento da empresa perante o mercado.

\section{Referências}

BEAL, A. Gestão estratégica da informação: como transformar a informação e a tecnologia da informação em fatores de crescimento e de alto desempenho nas organizações. São Paulo: Atlas, 2004. 137p.

CAMPELLO, B. S. Organizações como fonte de informação. In: CAMPELLO, B. S. et al. (Org.) Fontes de informação para pesquisadores e profissionais. Belo Horizonte: Editora UFMG, 2000. p.35-48.

CHOO, C. W. A organização do conhecimento: como as organizações usam a informação para criar significado, construir conhecimento e tomar decisões. São Paulo: Senac Editora, 2003. 425p.

CLARKE, T.; ROLLO, C. Corporative initiatives in knowledge management. Education+ Training, v.43, n.4/5, p.206-14, 2001. Disponível em: <http://www.emeraldinsight.com/Insight/ viewPDF.jsp?contentType=Article\&Filename $=$ html/Output $/$ Published/EmeraldFullTextArticle/Pdf/0040430403.pdf > . Acesso em: 4 jul. 2009.

DAVENPORT, T. H.; PRUSAK, L. Ecologia da informação: por que só a tecnologia não basta para o sucesso na era da informação. São Paulo: Futura, 1998. 316p.

Conhecimento empresarial. Rio de Janeiro: Campus; São Paulo: Publifolha, 1999.237p. 
DE SORDI, J. O. Administração da informação: fundamentos e práticas para uma nova gestão do conhecimento. São Paulo: Saraiva, 2008. 185p.

KAYE, D. The importance of information. Library Management, v.16, n.5, p.6-15, 1995a. Disponível em: <http://www.emeraldinsight. com/Insight/view P D F.jsp? content Type= Article\&Filename $=$ html/Output / Published / EmeraldFullTextArticle/Pdf/0150160501.pdf>. Acesso em: 4 jul. 2009.

Sources of information, formal and informal. Library Management, v.16, n.5, p.16-19, 1995b. Disponível em: <http:// www.emeraldinsight.com/Insight/viewPDF.jsp?content Type= Article\&Filename $=$ html/Output / Published / EmeraldFullTextArticle/Pdf/0150160502.pdf $>$. Acesso em: 4 jul. 2009.

MUELLER, S. P. M. A ciência, o sistema de comunicação científica e a literatura científica. In: CAMPELLO, B. S. et al. (Org.) Fontes de informação para pesquisadores e profissionais. Belo Horizonte: Editora UFMG, 2000. p.21-34.

TOMAÉL, M. I. et al. Critérios para avaliar fontes de informação na Internet. In: SIMPÓSIO INTERNACIONAL DE BIBLIOTECONOMIA "PROF. DR. PAULO TARCÍSIO MAYRINK, 3., Marília, 1 a 3 det. 1999. Anais... Marília, 1999. p.271-280.

Critérios de qualidade para avaliar fontes de informação na Internet. In:TOMAÉL, M. I.; VALENTIM, M. L. P. (Org.) Avaliação de fontes de informação da Internet. Londrina: Eduel, 2004. p.19-40.

VALENTIM, M. L. P. Inteligência competitiva em organizações: dado, informação e conhecimento. DataGramaZero, Rio de Janeiro, v.3, n.4, ago. 2002. Disponível em: <http://www.dgz.org.br/ago02/ F_I_art.htm>. Acesso em: 15 jan. 2006.

Processo de inteligência competitiva organizacional. In: VALENTIM, M. L. P. (Org.) Informação, conhecimento e inteligência organizacional. Marília: Fundepe Editora, 2006. p.9-24. 



\title{
16 \\ O COMPORTAMENTO \\ INFORMACIONAL DE ADVOGADOS: UMA REVISÃO DA LITERATURA
}

\author{
Marli Vítor da Silva \\ Helen de Castro Silva Casarin
}

\section{Introdução}

$\mathrm{Na}$ atualidade, em razão do fenômeno denominado "explosão informacional", ${ }^{1}$ há um volume crescente do fluxo de informações e, consequentemente, dos recursos informacionais disponíveis, especialmente aqueles de acesso em meio eletrônico. Essa é uma característica verificada no setor jurídico brasileiro, pois há um fluxo abundante de produção de informação, que pode ser constatado pela grande proliferação de atos normativos, jurisprudência, doutrina, entre outros (Fullin, 2006). Esse acúmulo acentuado de informações torna cada dia mais difícil acessar ou localizar informações relevantes.

Nesse contexto, o bibliotecário jurídico é um profissional extremamente importante, visto que é a partir de suas atribuições e habi-

1 "A explosão informacional, caracterizada, sobretudo, pela aceleração dos processos de produção e de disseminação da informação e do conhecimento, acelerou o que se convencionou chamar 'sociedade da informação', caracterizada pelo elevado número de atividades produtivas que dependem da gestão de fluxos informacionais, aliado ao uso intenso de tecnologias de comunicação e informação" (Moura, 2006, p.28). 
lidades que será possível a apropriação de informações capazes de satisfazer as necessidades informacionais dos profissionais da área jurídica, as quais são retiradas desse imenso universo informacional disponível. Segundo Passos (2001, p.1) “o bibliotecário jurídico é o profissional que facilita o acesso à informação jurídica de forma ágil e eficiente”. Além disso, os bibliotecários jurídicos são:

- atentos às fontes de informação indiferente ao seu suporte;

- juízes astutos das vantagens e desvantagens das várias fontes de informação;

- capazes de organizar a informação para que possa ser localizada e utilizada independentemente do seu suporte;

- especialistas no uso de fontes de informação jurídicas ou não (American..., [200?], p.4).

Cabe destacar, entretanto, que os elementos fundamentais, ou seja, que se encontram na base e subsidiarão as atividades do bibliotecário jurídico, são os estudos sobre o comportamento informacional, mais especificamente dos profissionais do direito, já que permitem a obtenção de elementos imprescindíveis para o desenvolvimento pleno de suas atividades no contexto jurídico.

Ressalte-se, contudo, que é imprescindível para o bibliotecário jurídico ter pleno conhecimento de que o contexto em que se inserem os profissionais do direito é extremamente complexo, pois possui características próprias que vão diferir, por exemplo, de um país para o outro, de uma área de atuação para outra, o que, consequentemente, pode influenciar decisivamente o comportamento informacional desses profissionais, comoé o caso dos advogados. Sob essa perspectiva, a comparação e o aproveitamento de estudos de comportamento informacional realizados internacionalmente ficam comprometidos, já que a realidade em que atuam os profissionais da área jurídica em âmbito nacional possui características diferentes, em razão, por exemplo, da própria formação do sistema jurídico brasileiro, que é diferente de outros países, e até da formação dos próprios profissionais que atuam na área. 
No âmbito do capítulo aqui proposto, portanto, serão apresentados e analisados alguns estudos já desenvolvidos sobre o comportamento informacional do profissional advogado, os quais podem ser incluídos na categoria de investigação denominada estudos de ocupações. O levantamento desses estudos foi realizado em bases de dados nacionais e internacionais, textuais e referenciais (Portal de Periódicos Capes, Wilson, Scopus, ProQuest, LISA e SciELO), em periódicos da área de ciência da informação (Information Research, Ciência da Informação, Journal of Documentation, Library Management etc.), bem como na Internet. O levantamento abrangeu um período que correspondeu os anos de 1980 a 2009. Alguns estudos foram localizados, ${ }^{2}$ porém não fizeram parte do levantamento, pois não foi possível acessá-los, visto que são trabalhos (dissertações) que não foram publicados.

Sendo assim, os estudos levantados e que serão apresentados são os seguintes: Vale (1988), Leckie et al. (1996), Silveira \& Ferreira (1996), Otike (1999), Otike \& Matthews (2000), Cole \& Kuhlthau (2000), Haruna \& Mabawonku (2001), Wilkinson(2001), Kuhlthau \& Tama (2001).

Vale destacar que não há pretensão quanto à exaustividade neste texto, mas, sim, a intenção de reunir e apresentar algumas das pesquisas já realizadas sobre o comportamento informacional de advogados, tanto internacional quanto nacional, e com isso traçar um panorama geral de investigação da área até o momento.

\section{Comportamento informacional}

O tema comportamento informacional vem sendo abordado por diversos estudiosos, contudo o conceito só passou a ser utilizado re-

2 Cf. A. Gelder, A study of information needs and habits of different groups of users of employment law. London, 1981; E. Cheatle, Information needs of solicitors. London, 1992; R. L. Walsh, Lawyer's attitude toward information. London, 1994. 
centemente, mais especificamente com o surgimento de estudos voltados à perspectiva de se tentar compreender o comportamento do indivíduo com relação à informação de uma forma mais ampla. Assim, algumas definições de comportamento informacional foram desenvolvidas e discutidas, podendo ser encontradas na literatura da área de comportamento informacional. Algumas delas são apresentadas a seguir.

Segundo Calva Gonzáles (1999), as ações empreendidas pelos indivíduos para obtenção de informação para satisfazer as suas necessidades informacionais podem ser definidas como comportamento de busca e uso da informação, ou comportamento informacional. Esse comportamento parte de um "amplo processo no qual a informação é percebida como uma construção social, criada pela interação de indivíduos e mensagens dentro de contextos organizacionais e sociais diversos" (Tiratel, 2000, p.7, tradução nossa).

Wilson (2000, p.49) define comportamento informacional (Information Behavior) como:

a totalidade do comportamento humano em relação às fontes e canais de informação, incluindo tanto busca passiva quanto busca ativa, além do uso da informação. Assim, tal comportamento inclui a comunicação face a face com os outros, bem como a recepção passiva de informação, como, por exemplo, assistir a comerciais de TV, sem muita atenção para a informação dada. (tradução nossa)

O autor acrescenta ainda que por comportamento informacional "entende-se que são aquelas atividades às quais uma pessoa pode engajar-se quando identifica suas próprias necessidades de informação, buscando satisfazê-las de muitas maneiras, usando ou transferindo aquela informação" (Wilson, 1999, p.249, tradução nossa).

Outros termos também são encontrados na literatura associados ao tema, quais sejam: comportamento de busca de informação (Information Seeking Behavior) e comportamento de busca em sistemas de informação (Information Search Behavior). Esses dois conceitos são amplamente utilizados nos estudos realizados sobre a te- 
mática de comportamento informacional, sendo caracterizados por Wilson (1999, p.263, tradução nossa) como: (a) o comportamento de busca de informação que diz respeito "a variedade de métodos que as pessoas utilizam para descobrir e ter acesso a fontes de informação"; e (b) o comportamento de busca em sistemas de informação que se relaciona com as "interações entre o usuário da informação e os sistemas de informação baseados em computador".

Sendo assim, Wilson (1999) propõe que a área de pesquisa de comportamento informacional deve ser encarada da seguinte forma: comportamento informacional (Information Behavior) pode ser visto como o campo mais geral de investigação, o qual engloba o subcampo comportamento de busca de informação (Information Seeking Behavior), e o termo comportamento de busca em sistemas de informação (Information Search Behavior) pode ser entendido como um subcampo do comportamento de busca de informação (Information Seeking Behavior).

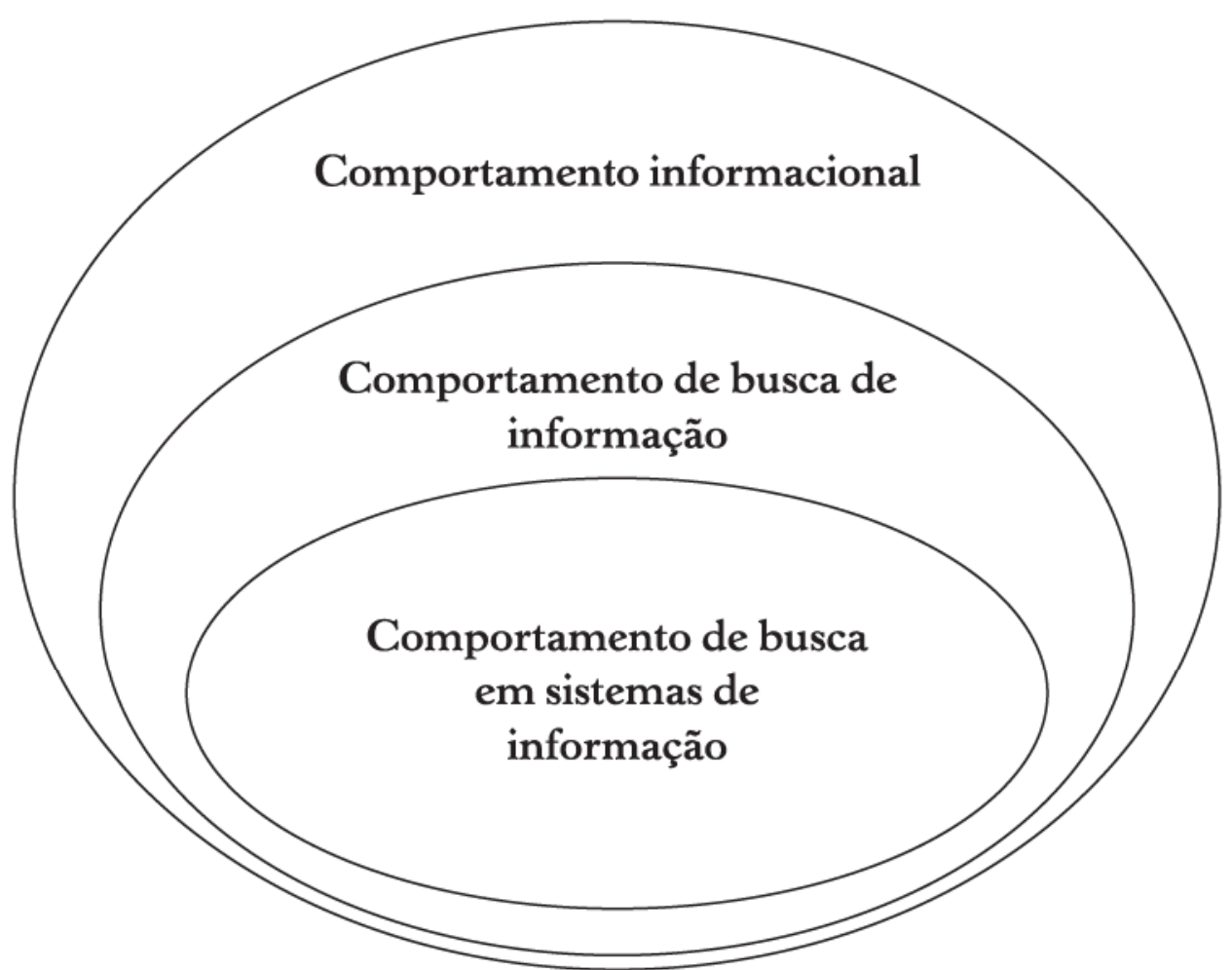

Figura 1 - Modelo das áreas de pesquisa de busca de informação e de busca em sistemas de informação.

Fonte: Wilson (1999, p.263). 
É importante mencionar que tanto o "comportamento de busca de informação" quanto o "comportamento de busca em sistemas de informação" enfatizam a atividade proposital, trazendo a "busca ativa" como a principal forma de buscar a informação. Contudo, segundo Wilson \& Wash (1996), além da busca ativa, existem outros modos de busca que também podem ser observados, tais como:

- Atenção passiva: tal como ouvir rádio ou assistir a programas de televisão, em que pode não haver nenhuma busca de informação pretendida, mas a aquisição da informação pode, contudo, acontecer.

- Busca passiva: podem parecer termos contraditórios, mas significa aquelas ocasiões quando um tipo de busca (ou outro comportamento) resulta na aquisição da informação que parece ser relevante para o indivíduo.

- Busca em curso: em que a busca ativa já estabeleceu a estrutura básica de ideias, crenças, valores etc., mas a continuação da busca ocasionalmente é levada a cabo para atualizar ou expandir suas estruturas.

Pode-se observar, então, que o comportamento informacional está intimamente relacionado com a busca da satisfação das necessidades de informação, e para que isso ocorra os indivíduos fazem uso dos mais diversos meios e métodos.

Cabe destacar também que o comportamento informacional varia de acordo com a área de especialidade e de interesse de cada pesquisador, ou seja, qualquer pessoa ou setor da sociedade possui certo comportamento informacional ao buscar a informação de que necessita, e isso está relacionado com, por exemplo, sua atividade de trabalho (Calva Gonzáles, 1999). Tal comportamento "segue alguns padrões que se referem às semelhanças que apresentam determinados setores sociais ao buscar a informação em fontes e recursos informacionais" (Calva Gonzáles, 2004, p.268, tradução nossa). Dessa forma, diferentes áreas dão preferência a canais diferentes para comunicar seus resultados e construírem suas pesquisas. Essas variações, conforme Mueller (2005), são decorrentes do prestígio ou valor que cada área atribui aos diversos canais de comunicação. 
O estudo do comportamento informacional de pesquisadores de diferentes áreas, por exemplo, muitas vezes produz resultados divergentes e a comparação entre elas é polêmica. No entanto, os autores delineiam alguns indicadores que nos servem de referência.

Mueller (2005), por exemplo, compara o uso de diferentes canais entre as áreas. Conforme a autora, as pesquisas nas ciências experimentais são geralmente realizadas em equipes, se apoiam em paradigmas universalmente aceitos e são divulgadas por meio de artigos publicados prioritariamente em periódicos de circulação internacional e em língua inglesa. Nas áreas classificadas como ciências sociais e humanas, ao contrário, as pesquisas, de modo geral, são realizadas individualmente pelos pesquisadores que tendem a produzir textos mais longos, publicados principalmente como livros ou capítulos de livros.

Conforme Crespo \& Caregnato (2003, p.249), no entanto, mesmo havendo diferenças no comportamento informacional dos pesquisadores das diversas áreas, alguns traços são comuns a todos. Por exemplo, a comunicação informal assume uma importância fundamental para os pesquisadores em geral. Segundo as autoras, outra característica relevante dos pesquisadores, além da comunicação informal, é a demanda permanente por informações, pois "a busca e o uso de informação por pesquisadores são contínuas e permeiam todas as etapas do processo de construção do conhecimento, desde o planejamento do projeto até a apresentação dos resultados" (ibidem, p.250).

Com base no exposto anteriormente, foi realizado o levantamento bibliográfico sobre a temática em questão. Ressalte-se que foram localizados, no período analisado, doze estudos sobre o comportamento informacional de advogados, e só foi possível ter acesso a apenas nove deles. A grande maioria desses estudos foi realizada em âmbito internacional, ou seja, oito deles; apenas um foi realizado no Brasil. Os estudos apresentados correspondem, em sua grande maioria, a artigos de periódicos (oito), e foi possível ter acesso a apenas uma tese de doutorado. 


\section{O comportamento informacional de advogados}

Vale (1988) realizou uma investigação (pesquisa de campo) cujo objetivo era caracterizar o comportamento informacional de advogados no contexto de trabalho. Para a coleta de dados o autor utilizou-se de questionário via e-mail, o qual era composto de 39 questões. Foram selecionados dois mil profissionais para participar do estudo, e somente 751 deles responderam ao questionário enviado. Os principais resultados do estudo estão sumarizados a seguir:

- Vários fatores podem influenciar o comportamento informacional dos advogados: há hipóteses de que o "custo" é um fator significante no uso da informação, podendo influenciar tanto de forma positiva quanto negativa; e o tempo de atuação profissional pode influenciar negativamente a busca de informações.

- O comportamento informacional é influenciado pelas necessidades desenvolvidas no cotidiano profissional relacionado às tarefas a serem executadas, bem como os recursos informacionais disponíveis.

Assim, por exemplo, quando a necessidade de informação é moderada e os custos são considerados altos, alguns advogados tendem a substituir uma fonte de informação por outra. Por sua vez, quando a necessidade de informação é considerada muito "forte", os advogados tendem a ver duas ou mais fontes de informação como complementares.

- O acesso é um fator muito importante com relação ao uso de tecnologias informacionais.

Leckie et al. (1996) desenvolveram, por meio de uma revisão de literatura, um estudo sobre o comportamento informacional de três diferentes grupos de profissionais (engenheiros, profissionais da saúde e advogados), para proporem um modelo de comportamento informacional que poderia ser facilmente aplicado aos muitos pro- 
fissionais das mais diversas áreas. Esses grupos de profissionais foram escolhidos por haver alguns estudos já realizados sobre o tema e por representarem profissões de campos opostos. Com relação ao comportamento informacional de advogados, os autores puderam constatar que:

- O comportamento informacional de tais profissionais é altamente dependente da função que exercem.

- Para os advogados é crucial acessar uma ampla variedade de fontes de informação no desenvolvimento de suas tarefas, desde fontes de informação primárias e secundárias impressas até bases de dados de ampla cobertura.

- A frequente especialização dos advogados em uma determinada área do direito tem um impacto imediato no comportamento informacional dos mesmos.

- A experiência profissional também tem um impacto decisivo no comportamento informacional dos advogados, bem como o contexto organizacional em que está inserido - tamanho do escritório, por exemplo.

Silveira \& Ferreira (1996) realizaram um estudo sobre o comportamento informacional de advogados e estudantes de direito, mais especificamente sobre o uso das tecnologias de acesso à informação na área do direito do trabalho. Foi utilizado como instrumento de coleta de dados um questionário com dezessete questões, e tal instrumento foi construído com base em determinadas premissas originadas do conhecimento empírico das autoras. O questionário foi aplicado durante um mês aos usuários da biblioteca do Tribunal Regional do Trabalho.

Como resultado do estudo, constatou-se que os advogados se engajam na busca por informações para embasar o seu posicionamento jurídico, e a fonte de informação mais utilizada é a jurisprudência, seguida de acórdãos na íntegra. Verificou-se também que os advogados costumam utilizar os serviços de bibliotecas jurídicas como fonte de informação para o desenvolvimento de suas atividades profissio- 
nais. Um resultado interessante dessa investigação diz respeito ao uso de fontes de informação eletrônica, visto que sua utilização é bastante acentuada por esse grupo de profissionais. Porém, segundo as autoras, esse dado não pode ser generalizado, pois muitos dos advogados que participaram da pesquisa são usuários frequentes e já estão habituados às novas tecnologias de acesso à informação.

Otike (1999) conduziu um estudo sobre o comportamento informacional de advogados oriundos do Reino Unido. Os dados foram coletados por meio de entrevistas semiestruturadas, as quais duraram por volta de trinta minutos. No total foram entrevistados 33 advogados. No estudo, verificou-se que:

- As necessidades de informação desses profissionais são altamente influenciadas pela natureza das atividades que desenvolvem.

- A experiência profissional tem uma considerável influência sobre as suas necessidades informacionais, bem como sobre seus hábitos de busca por informação.

- Na maioria das vezes a busca por informação é delegada a outras pessoas, tais como estagiários de Direito, secretárias e profissionais (advogados) com pouca experiência.

- Há uma preferência marcante pelas mídias impressas, visto que as fontes de informação eletrônicas são usadas somente em última instância, como um último recurso.

- O uso de colegas ou contato pessoal é um método muito utilizado para ter acesso à informação.

Cole \& Kuhlthau (2000) desenvolveram um estudo cujo foco foi verificar e comparar o comportamento informacional de advogados em início de carreira com aqueles que já atuam há mais de sete anos na profissão. Foram comparados seus conceitos de tarefa, busca de informação e informação. Para tanto, foram selecionados quinze advogados que atuavam em Montreal e em New Jersey. A coleta de dados foi realizada por meio de entrevista. Os resultados obtidos foram os seguintes: 
- Com relação às informações necessárias ao desenvolvimento de um caso ou um fato isolado, os advogados em início de carreira tendem a tratar o reconhecimento e a solução do problema jurídico separadamente.

- Uma conceituação inicial para possíveis soluções de um caso ou um problema do cliente permite que os advogados mais experientes agreguem valor às informações acessadas. A agregação de valor segue alguns parâmetros, quais sejam: os advogados mais experientes localizam fatos e informações que são apresentados de maneira que pareçam, de certa forma, "reais" para, por exemplo, os clientes e os juízes; o acréscimo de valor às informações acessadas permite que os advogados mais experientes construam e compreendam novos conhecimentos com o objetivo de beneficiar os seus clientes; são localizadas informações consideradas rentáveis que possam ser transformadas em valor agregado.

Sendo assim, Cole \& Kuhlthau (2000, p.111, tradução nossa) afirmam que a busca de informação jurídica "é um processo que permite a construção e compreensão de conhecimentos para agregar valor a um empreendimento (por exemplo, um cliente e um juiz)".

Em 2000, Otike \& Matthews (2000) realizaram um estudo de caso como parte de um programa de pesquisa de doutorado. Nessa pesquisa, Otike \& Matthews buscaram investigar as necessidades e a provisão de informação de advogados que atuam no Quênia, mais especificamente nas cidades de Eldoret, Kisumu e Nairobi. Seus principais objetivos foram: identificar o propósito pelo qual os advogados buscam informação; estabelecer o tipo de informação usada pelos advogados para suprir suas necessidades informacionais; e determinar os problemas que os advogados encontram para ter acesso e usar informação. A coleta de dados foi realizada por meio de entrevista semiestruturada e observação participante. Destaque-se que, para essa pesquisa, foi selecionado apenas um advogado, visto que se pretendia realizar um estudo de caso em profundidade, na tentativa de se obter mais detalhes sobre o comportamento informacional do advogado selecionado. Como afirmam Otike \& Matthews (2000, p.241), 
"embora limitado a um advogado, o estudo demonstra os tipos de experiências e problemas que os advogados de escritórios de pequeno porte no país vivenciam para ter acesso à informação jurídica”. Os resultados levantados nesse estudo foram os seguintes:

- O trabalho do advogado é altamente influenciado pela necessidade de seus clientes.

- Para ter acesso às informações de que necessita possui uma coleção de materiais informacionais limitada, o que é uma das características de escritórios de pequeno porte.

- Para ter acesso a informações adicionais utiliza fontes de informação externas ao escritório, quais sejam: High Court library, ou materiais de outros escritórios.

- A quantidade de informação de que necessita dependerá da natureza do trabalho que está sendo desenvolvido, o que, consequentemente, influenciará o processo de busca de informações.

- É inútil depender das bibliotecas das supremas cortes, pois são sobrecarregadas pelos interesses e necessidades dos juízes, por exemplo.

- Para se maximizar a disponibilidade da informação jurídica no país se faz necessário a criação de uma biblioteca jurídica com uma base cooperativa.

Haruna \& Mabawonku (2001) desenvolveram um estudo com o intuito de determinar o comportamento informacional de advogados que atuam em Lagos (Nigéria). Foram selecionados para participar da pesquisa 361 advogados. Para coletar os dados da pesquisa foi utilizado um questionário constituído de 25 questões. Os resultados demonstram que muitos advogados têm como principal fonte de informação as últimas decisões das cortes superiores, seguidas do conhecimento sobre a legislação recente, informações sobre conferências e seminários (nacionais e internacionais) e a aquisição e aplicação do denominado know-how legal. Outras fontes de informação também foram relacionadas: comunicação interpessoal com colegas, publicações governamentais e coleções pessoais. As fontes de infor- 
mação eletrônicas (como a Internet e bases de dados) são raramente consultadas. Um resultado interessante desse estudo é com relação ao uso da biblioteca, pois foi identificado que ela é muito utilizada pelos advogados, contudo, na maioria das vezes, não satisfaz as necessidades dos mesmos.

Wilkinson (2001) procurou investigar o comportamento informacional de advogados que atuam na cidade de Ontário (Canadá), mais especificamente verificar os problemas que envolvem a sua prática profissional, a qual conduz para a busca de informação. Os dados da pesquisa foram obtidos por meio de um estudo realizado com advogados em 1996. Dos 180 advogados entrevistados nessa pesquisa, 154 permitiram que as suas entrevistas fossem usadas para a análise no estudo desenvolvido em 2001. Na sua análise, a autora constatou que:

- A maioria dos advogados levantou problemas que envolvem a administração de suas práticas profissionais.

- Para tentar resolver seus problemas com relação à prática profissional, os advogados têm preferência por fontes informais (tais como colegas, clientes, entre outras).

- Os advogados preferem fontes de informação internas de suas organizações do que de fontes externas, embora isso ocorra com menor frequência com advogados que pertencem a escritórios considerados de pequeno porte.

Kuhlthau \& Tama (2001) conduziram uma investigação que tinha como objetivo obter melhor compreensão do comportamento informacional de advogados. Ou seja, com o estudo tentou-se buscar um maior entendimento sobre as atividades que envolvem os advogados como um grupo particular de usuários de informação; como esses profissionais usam a informação para realizar seu trabalho; e a função que exercem os mediadores no processo de busca e uso da informação. Os dados foram coletados por meio de entrevistas semiestruturadas, as quais foram realizadas com oito profissionais, sendo que cada uma durou, aproximadamente, uma hora. 
Os dados dessa investigação evidenciaram que esses profissionais frequentemente estão envolvidos em tarefas complexas, as quais requerem um processo construtivo de interpretação, aprendizagem e criação. Para realizar tais tarefas, os advogados demonstram uma preferência marcante por fontes de informação impressas, em detrimento das fontes de informação eletrônicas. Por fim, os resultados demonstraram que os advogados desejam serviços de informação altamente customizados com base em suas necessidades de informação.

\section{Considerações finais}

Neste capítulo, buscou-se apresentar e analisar alguns dos estudos já desenvolvidos sobre o comportamento informacional de advogados, os quais podem ser incluídos na categoria de pesquisa denominada ocupacional. Por meio do levantamento realizado pôde-se traçar um panorama geral de investigação na área até o momento.

Observa-se, diante dos resultados levantados e expostos anteriormente, que tais estudos buscavam, de maneira geral, caracterizar o comportamento informacional dos advogados pesquisados. Dessa forma, nesses estudos, determinadas características do comportamento informacional de advogados ficaram mais evidentes, pois aparecem nos resultados das pesquisas de forma recorrente, quais sejam: certa preferência por fontes de informação impressas em detrimento das fontes de informação eletrônicas disponíveis; prioridade à comunicação interpessoal e por fontes de informação informais, como colegas clientes, entre outros; e, por fim, o comportamento informacional sofre influências das tarefas e atividades desenvolvidas no ambiente de trabalho. Esses resultados sugerem, de certa forma, que os advogados (como um grupo específico de profissionais) possuem um determinado padrão de comportamento informacional, e que esse comportamento está intimamente relacionado com o desenvolvimento de suas atividades e funções exercidas no trabalho. 
Pode-se verificar também que a grande maioria das pesquisas levantadas utilizou entrevista semiestruturada como procedimento de coleta de dados. Esse é um dado interessante, pois evidencia que pesquisas de abordagem qualitativa estão sendo realizadas sobre a temática de comportamento informacional, em detrimento das abordagens quantitativas, apesar de ainda serem bastante realizadas na área em questão.

Constata-se, contudo, a falta de literatura a respeito do comportamento informacional de advogados brasileiros, visto que apenas uma pesquisa foi localizada sobre o tema no país. Dessa forma, não há elementos e parâmetros suficientes para que se possa caracterizar e, consequentemente, ter conhecimento da área em âmbito nacional. Isso demonstra que há uma demanda por estudos que tratem sobre o comportamento de advogados na busca de informações, em âmbito nacional.

Em suma, os dados apresentados neste texto permitem visualizar algumas das principais características dos estudos já realizados sobre o comportamento informacional de advogados, tanto em âmbito nacional como internacional. E, com isso, traçar novos caminhos para os estudos que forem realizados posteriormente na área de biblioteconomia e ciência da informação sobre a temática em questão, bem como levantar subsídios extremamente relevantes para a atuação do bibliotecário jurídico.

\section{Referências}

AMERICAN ASSOCIATION OF LAW LIBRARIES. Finding your way in the information age: the many roles of law libraries. Chicago: Lexis-Nexis, [200?]. 8p. Disponível em: <http:// www.aallnet.org/>. Acesso em: 23 nov. 2009.

CALVA GONZÁLEZ, J. J. El comportamiento en la búsqueda de información de los investigadores del área de Humanidades y Ciencias Sociales. Investigación Bibliotecológica: Archivonomía, Bibliotecología e Información, v.13, n.27, p.3-29, 1999. 
Las necesidades de información: fundamentos teóricos y métodos. México: Universidad Nacional Autónoma de México, 2004. 285p.

COLE, C.; KUHLTHAU, C. C. Information and information seeking of novice versus expert lawyers: how experts add value. The New Review of Information Behavior Research, v.1, p.103-15, 2000.

CRESPO, I. M.; CAREGNATO, S. E. Comportamento de busca de informação: uma comparação de dois modelos. Em Questão, Porto Alegre, v.9, n.2, p.271-81, jul./dez. 2003.

FULLIN, C. B. Perspectivas futuras para a demanda de profissionais da informação e a organização da informação jurídica nos escritórios de advocacia de Campinas. Revista Digital de Biblioteconomia e Ciência da Informação, Campinas, v.3, n.2, p.31-42, jan./jun. 2006. Disponível em: <http://server01.bc.unicamp.br/seer/ojs/ index.php>. Acesso em: 25 ago. 2008.

HARUNA, I.; MABAWONKU, I. Information needs and seeking behavior of legal practitioners and the challenges to law libraries in Lagos, Nigéria. International Information and Library Review, v.33, n.1, p.69-87, 2001.

KUHLTHAU, C. C.; TAMA, S. L. Information search process of lawyers: a call for "just for me" information services. Journal of Documentation, v.57, n.1, p.25-43, jan. 2001.

LECKIE, G. J. et al. Modeling the information seeking of professional: a general model derived from research on engineers, health care professionals and lawyers. Library Quarterly, v.66, n.2, p.161-93, 1996.

MEADOWS, A. J. A comunicação científica. Brasília, DF: Briquet de Lemos, 1999.

MERCER, P. et al. The practice of ethical precepts: Dissecting decisionmaking by lawyers. Canadian Journal of Law and Jurisprudence, n.9, p.141-60, 1996.

MUELLER, S. P. M. A publicação da ciência: áreas científicas e seus canais preferenciais. DataGramaZero: Revista de Ciência da Informação, Rio de Janeiro, v.6, fev. 2005. Disponível em: <http:// www.dgz.org.br/dez06/F_I_art.htm>. Acesso em: 29 nov. 2006.

OTIKE, J. The information needs and seeking habits of lawyers in England: a pilot study. International Information and Library Review, v.31, n.1, p.19-39, 1999. 
OTIKE, J.; MATTHEWS, G. Legal information needs of lawyers in Kenya: a case study. Library Management, v.21, n.5, p.241-51, 2000. SILVEIRA, A. G.; FERREIRA, R. M. Uso das tecnologias de acesso à informação na área do Direito do Trabalho. In: SIMPÓSIO BRASIL-SUL DE INFORMAÇÃO, 1996, Londrina. Disponível em: $<$ http://eprints.rclis.org/4275/>. Acesso em: 25 nov. 2008.

TIRATEL, S. R. de. Accessing information use by humanists and social scientists: A study at the Universidad de Buenos Aires, Argentina. The Journal of Academic Librarianship, v.26, n.5, p.346-54, set. 2000.

VALE, M. E. Information structure and information seeking behavior of lawyers. Stanford, 1988. 143f. Tese (PhD in Filosofia) - Stanford University.

WILKINSON, M. A. Information sources used by lawyers in problemsolving: An empirical exploration. Library E Information Science Research, v.23, n.3, p.257-76, 2001.

WILSON, T. D. Models in information behavior research. Journal of Documentation, v.55, n.3, p.249-70, 1999.

Human information behavior. Information Science Research, v.3, n.2, 2000 .

WILSON, T. D.;WASH, C. Information behavior: An interdisciplinary perspective. Sheffield: University of Sheffield. Department of Information Studies, 1996. Disponível em: <http:// informationr.net/tdw/publ/infbehav/cont.html>. Acesso em: 10 mar. 2007. 



\title{
17 \\ A RELAÇÃO ENTRE A INFORMAÇÃO ORGÂNICA E A GESTÃO DOCUMENTAL
}

\author{
Mariana Lousada \\ Marta Lígia Pomim Valentim
}

\section{Introdução}

O objetivo deste capítulo é aprofundar as discussões referentes ao conceito de informação orgânica por meio da identificação de conceitos extraídos na literatura e também identificar as relações que essa realiza com a gestão documental. Buscaremos destacar alguns elementos que ajudem a caracterizar e distinguir essas relações. Isso porque uma das características principais desse tipo de informação é ser registrada, visto que se trata de um campo teórico ainda em formação e propício a intensas discussões e novas aproximações.

\section{Conceito e características da informação orgânica}

O conceito de informação vem do latim informare e significa processo de informar-se, que tem por finalidade reduzir a incerteza e gerar novo conhecimento. Lira et al. (2008, p.170) defendem que "A informação é o conjunto de dados úteis às organizações e aos seres humanos, no sentido de dar subsídios para uma tomada de decisão eficaz". 
Os termos dado e informação, muitas vezes, são empregados como sinônimos, pela proximidade e complexidade de definição de significado. Contudo, deve-se deixar clara a distinção entre ambos.

Miranda (1999, p.286) define dado como um "conjunto de registros qualitativos ou quantitativos conhecidos que organizado, agrupado, categorizado e padronizado adequadamente transformase em informação”. Davenport \& Prusak (1998, p.18) explicam que dados são "observações sobre o estado do mundo", e, ainda, pode ser facilmente estruturado por meio de sistemas computacionais, é facilmente transferível e necessariamente requer algum tipo de análise ou de tratamento. Um dado não se constitui em uma informação, pois para isso é necessário algum tipo de ação junto a ele, ou seja, é necessário agregar algum tipo de valor. A ação de atribuir significado a um dado em um determinado contexto pode ser chamada de informação. Ilharco (2003, p.180) contextualiza essa visão:

O surgir de algo que informa é o encontrar daquilo que se estava a procurar. A informação são os dados com significado relevante para a ação em que o gestor está envolvido, porque alteram, completam, modificam, desenvolvem o todo referencial, a rede de relações que para ele mesmo gestor liga umas coisas a outras, fatos a eventos, a pessoas, a ideias, etc. São essas ligações e referências que abrem, fecham e sugerem possibilidades que constituem o próprio significado.

Para Sordi (2008, p.7), "ao se manipularem dados, organizandoos, consolidando-os, ou seja, dando-lhes um propósito, geram-se informações”. Conclui-se que o significado está nos indivíduos. O sujeito atribui significado a um determinado dado (entendido aqui como elemento sem valor significativo), que, quando inserido em um contexto pelo sujeito, se tornará uma informação. Dado e informação são sempre aquilo que são num determinado contexto intencional. Percebemos que todas as relações existentes entre dado e informação podem ser caracterizadas como um processo cíclico, conforme apresentado no esquema a seguir: 


\section{DADO}

(Elemento sem significado)

そ)

SUJEITO

(Atribui valor ao dado)

ת

\section{SIGNIFICADO}

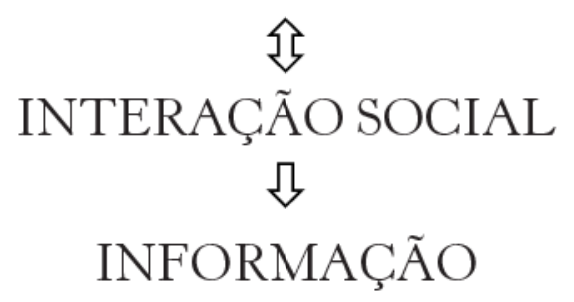

A literatura apresenta diferentes conceituações e definições para o termo "informação", e recorrentemente é entendida como necessária para uma decisão, seja simples, seja complexa. A quantidade de informação pode variar de acordo com a complexidade da situação. Para McGarry (1999, p.4), a informação pode ser:

- considerada como um quase sinônimo do termo fato;

- um reforço do que já se conhece;

- a liberdade de escolha ao selecionar uma mensagem;

- a matéria-prima da qual se extrai o conhecimento;

- aquilo que é permutado com o mundo exterior e não apenas recebido passivamente;

- definida em termos de seus efeitos no receptor;

- algo que reduz a incerteza em determinada situação.

A partir do exposto e dando andamento ao objetivo deste capítulo, que é analisar a relação entre a informação orgânica e a gestão documental, iniciaremos a discussão conceituando esse tipo específico de informação.

Ressalte-se, portanto, que a informação orgânica é gerada em decorrência da execução das funções organizacionais, pelos próprios membros da organização, que ao mesmo tempo são produtores e consumidores, encontra-se contida nos registros físico das 
transações de atividades, tarefas ou tomada de decisão. "A informação orgânica é produzida internamente, sendo produto resultante da execução das funções e das atividades organizacionais" (Lousada \& Valentim, 2008, p.254), ou seja, considera-se esse tipo de informação como de caráter orgânico pelo contexto interno de produção; e, ainda, por se tratar de informações registradas independentemente do tipo de suporte, encontra-se diretamente relacionada a um suporte, acumulada por um sujeito que é produtor desses documentos.

A informação orgânica é produto das atividades executadas na organização, elas são produzidas no contexto do exercício das funções administrativas, o registro físico das transações de uma determinada atividade, tarefa ou tomada de decisão. Portanto, é insumo para os gestores desempenharem suas funções e tomarem decisões.

Conceituar informação orgânica ainda é uma tarefa difícil de ser realizada dentro dos parâmetros teóricos da arquivologia e da ciência da informação, isso porque se trata de um conceito ainda recente na literatura, o que o torna passível de muitos questionamentos pelos estudiosos que se debruçam sobre o tema. Os teóricos que mais contribuem para a consolidação desse conceito são os canadenses e os norte-americanos, uma vez que iniciaram estudos sobre essa temática nos anos 1990. Segundo Moreno (2007, p.9), "a noção de informação arquivística ou informação orgânica é recente na literatura da área e ainda precisa de aprofundamento teórico".

Lopes (1996, p.32) discorre que "é orgânica a informação que pertence à pessoa ou organização que a acumulou”, ou seja, é intrínseca a organização/instituição que a gerou, sendo, portanto, fruto dos componentes que a integram. Pode-se considerar, ainda, que a combinação entre si, ou seja, o cruzamento dessas informações pode gerar novas informações também de caráter orgânico. Outra definição interessante e que se enquadra no nosso entendimento é oferecida por Carvalho \& Longo (2002, p.115): "informação orgânica é um conjunto de informações sobre um determinado assunto, materializado em documentos arquivísticos e foi produzido no cumprimento das atividades e funções da organização". 
Diante das especificidades inerentes à conceituação da informação orgânica, fica nítida a sua relação com o desempenho estratégico das instituições, especialmente as que se encontram inseridas em ambientes competitivos, geralmente instituições particulares. Isso em razão de sua característica orgânica, ou seja, trata-se de um recurso produzido internamente, portanto de caráter estratégico, podendo incidir diretamente na atuação da organização.

Rosseau \& Couture (1998, p.65) ressaltam que as organizações que compreenderam a importância estratégica da informação, e ainda os membros que comunicarem rapidamente e sem distorção por meio da hierarquia, alcançam vantagem decisiva nas decisões em relação aos concorrentes. Por essa razão, a organização precisa deixar claro o valor que esse recurso pode exercer em benefício da própria organização, bem como estabelecer mecanismos e instrumentos que facilitem a gestão dos fluxos documentais.

Os autores Rousseau \& Couture (1998, p.64) propõem um esquema, detalhando de que forma a proveniência da informação se estabelece no âmbito da organização, e também suas diferentes naturezas.

A informação orgânica se estabelece como um dos agentes responsáveis pelo aumento da competitividade e, consequentemente, sobrevivência das organizações, pois exerce papel importante por meio da realização de análises informacionais diferenciais com agregação de valor, transformando-as em insumos potencialmente estratégicos.

As estratégias baseadas em informações tornam-se um diferencial, porque fornecem subsídios para os níveis mais altos da administração no desenvolvimento de estratégias, tanto no curto e médio prazos quanto no longo prazo, diminuindo riscos e incertezas no momento da definição de metas e ações estratégicas, a médio e longo prazos, e ainda subsidiando o processo de tomada de decisão, influenciando diretamente o desempenho da organização. 


\section{Gestão documental}

A gestão documental apresenta seus primeiros fundamentos no período pós-Segunda Guerra Mundial, com o crescimento do volume de documentos produzidos pelas instituições públicas. O conceito de gestão de documentos ou records management foi desenvolvido nos Estados Unidos, por volta dos anos 1940 e 1950. Alguns aspectos favoreceram que ocorresse no país herança multicultural, trazendo para os diferentes estados padrões diversificados de cultura administrativa; grande crescimento geométrico do volume de documentos; progresso tecnológico e econômico do país e seu grande interesse por aspectos relativos à eficácia e eficiência (Fonseca, 1998).

Inicialmente, o conceito relacionava-se às áreas administrativa e econômica e não à arquivística, uma vez que buscava especialmente aperfeiçoar o funcionamento da administração, restringindo a quantidade de produção documental, facilitando seu acesso e a regulamentação com a finalidade de eliminação ou guarda permanente. Sendo assim:

A gestão de documentos originou-se na impossibilidade de se lidar, de acordo com "moldes tradicionais", com as massas cada vez maiores de documentos produzidos pelas administrações públicas americanas e canadenses. Assim, a partir das soluções apontadas por comissões governamentais nomeadas para a reforma administrativa dos Estados Unidos e do Canadá, no final da década de 40 do século XX, foram estabelecidos princípios de racionalidade administrativa, a partir da intervenção nas etapas do ciclo documental, a saber: produção, utilização, conservação e destinação de documentos. (Fonseca, 1998, p.38)

Em nível internacional, o Dicionário de Terminologia Arquivística (1984), do Conselho Internacional de Arquivos (CIA), considera que a gestão de documentos diz respeito a uma área da administração geral relacionada com a busca de economia e eficácia em produção, manutenção, uso e destinação final dos mesmos. Para o Glossary of Archival and Records Terminology, gestão de documentos é o contro- 
le sistemático e administrativo dos documentos durante o ciclo de vida, de forma que assegure eficiência e economia em sua criação, uso, manuseio, controle, manutenção e destinação (Pearce \& Moses, 2005 apud Indolfo, 2007, p.40).

No Brasil, a gestão de documentos institucionalizou-se com a aprovação da Lei n.8.159 de 8 de janeiro de 1991, que dispõe sobre a política nacional de arquivos públicos e privados. A mencionada lei, em seu artigo $3^{\circ}$, define o conceito como o "conjunto de procedimentos e operações técnicas referentes à sua produção, tramitação, uso, avaliação e arquivamento em fase corrente e intermediária, visando à sua eliminação ou recolhimento para guarda permanente" (Brasil, 1991). A Constituição Federal de 1988, por meio do artigo 216, já deliberava paramentos para a gestão, porém esse se restringia ao poder público, não abarcando os sistemas privados, definindo da seguinte forma: "Cabem à administração pública, na forma de lei, a gestão da documentação governamental e as providências para franquear sua consulta a quantos dela necessitem".

O Dicionário Brasileiro de Terminologia Arquivística (Brasil, 2005, p.100) define o conceito como o conjunto de procedimentos e operações técnicas referentes à produção, tramitação, uso, avaliação e arquivamento de documentos em fase corrente e intermediária, visando à sua eliminação ou recolhimento.

A gestão documental é um processo administrativo que permite analisar e controlar sistematicamente, ao longo de seu ciclo de vida, a informação registrada que se cria, recebe, mantém e utiliza numa organização em correspondência com sua missão, objetivos e operações. Também se considera um processo para manter a informação em um formato que permita seu acesso oportuno, porque são necessários tarefas e procedimentos para cada fase e exploração desta informação registrada, que é evidência das atividades e transações das organizações e que lhes permita obter uma maior eficácia. (Ponjuán Dante, 2004, p.129).

A partir do exposto em relação ao conceito da gestão, Rhoads (1989, p.2, tradução nossa) descreve as fases e os elementos que compõem um programa de gestão documental: 
- Produção: concepção e gestão de formulários, preparação e gestão de correspondências, gestão de informes e diretrizes, fomento de sistemas de gestão da informação e aplicação de tecnologias modernas a esses processos.

- Utilização e conservação: criação e melhoramento dos sistemas de arquivos e de recuperação de dados, gestão de correio e telecomunicações, seleção e uso de equipamento reprográfico, análise de sistemas, produção e manutenção de programas de documentos vitais e uso de automação e reprografia nestes processos.

- Destinação: identificação e descrição das séries documentais, estabelecimento de programas de avaliação e destinação de documentos, arquivamento intermediário, eliminação e recolhimento dos documentos de valor permanente às instituições arquivísticas.

Pimenta (2008, p.9) acrescenta mais cinco fases, que devem compreender no programa completo de gestão:

- Tramitação: estudo das instâncias de decisão, padronização e controle do fluxo documental (workflow).

- Organização e arquivamento: de acordo com os critérios definidos no plano de classificação.

- Reprodução: duas razões para a reprodução: 1. reprodução visando à preservação do documento original de guarda permanente; e 2. reprodução visando à substituição do documento em papel pelo microfilme. O documento em papel de guarda temporária poderá ser eliminado e o microfilme deverá ser preservado pelo prazo indicado na Tabela de Temporalidade de Documentos de Arquivo.

- Classificação: recupera o contexto de produção dos documentos, isto é, a função e a atividade que determinaram a sua produção e identificam os tipos/séries documentais.

- Avaliação: trabalho multidisciplinar que consiste em identificar valores para os documentos e analisar seu ciclo de vida, com vistas a estabelecer prazos para sua guarda e destinação (eliminação ou guarda permanente). 
A partir do exposto, consideramos que os principais objetivos da gestão são: racionalizar a produção dos documentos; controlar o fluxo de documentos e a organização dos arquivos; normalizar os procedimentos para avaliação, transferência, recolhimento, guarda e eliminação de documentos; agilizar o acesso aos arquivos e às informações; agilizar o processo decisório; garantir economia, eficiência e eficácia na administração pública ou privada; promover a transparência das ações administrativas; incentivar o trabalho multidisciplinar e em equipe; preservar o patrimônio documental considerado de guarda permanente; assegurar o pleno exercício da cidadania ( $\mathrm{Pi}$ menta, 2008, p.8-9).

A gestão documental identifica e racionaliza os fluxos formais de documentos que se encontram presentes na execução das atividades organizacionais. Pode-se ressaltar, assim, a importância desses para o cumprimento de questões legais, fiscais, contábeis, financeiras que fazem parte da competência da organização.

\section{Tipologias documentais}

A partir das reflexões realizadas anteriormente e apresentação dos conceitos que abarcam a proposta de discussão do capítulo, podemos tecer relações intrínsecas entre a informação orgânica e a gestão documental. Isso porque uma das características básicas quando nos referimos a esse tipo de informação é sua característica de ser considerado na medida em que se encontra registrada em um dado suporte. Para tanto, gerenciar os fluxos documentais torna-se imprescindível para a identificação das fontes orgânicas geradoras de informações e seu posterior monitoramento.

Uma das contribuições mais relevantes na identificação de tipologias documentais especificamente em ambientes empresariais foi realizada por Pazin (2005, p.16). A mesma autora distingue esses documentos de caráter orgânico como "produzidos de acordo com a estrutura jurídica, o regime tributário e as atividades técnicas desenvolvidas". 
Pazin realizou um estudo acerca do tema e obteve um diagnóstico sobre os principais tipos documentais produzidos em organizações, tanto públicas quanto privadas. A partir dessa análise, sistematizou e classificou-os em dez categorias: documentos de constituição, direção, reunião, recursos humanos, comunicação e marketing, administrativos, financeiros, contábeis e fiscais, jurídicos e, por fim, os documentos técnicos, cujo detalhamento será feito a seguir.

Os documentos de constituição são "os documentos que dão origem a qualquer instituição e permitem sua existência enquanto organismo social” (Pazin, 2005, p.16). Essa categoria é constituída por:

- Contrato social: "registro de acordo pelo qual duas ou mais pessoas físicas ou jurídicas estabelecem entre si algum(uns) direito(s) e/ou obrigação(ções)" (Bellotto, 2002, p.60). É responsável pela criação das sociedades empresariais (Ltdas.) ou simples.

- Estatuto: conjunto de normas jurídicas que regulamentam todos os atos e as atividades de determinada matéria, órgão, organização ou sociedade.

- Regimento: conjunto de normas que regem o funcionamento interno de uma instituição ou órgão ou o desempenho de cargos e funções.

- Certificado de inscrição no CNPJ (Cadastro Nacional de Pessoa Jurídica): "é o correspondente do 'CPF' das instituições. É obrigatório e dá identidade tributária ao contribuinte”. (Pazin, 2005, p.17)

Os documentos de direção são produzidos pela alta administração, e apresentam o planejamento dos rumos e estratégias de ação da organização, visando ao desenvolvimento e crescimento. São compostos pelos seguintes documentos:

- Planejamento estratégico: estabelecimento pela instituição de metas e objetivos a médio e longo prazos, visando alcançar o cumprimento da missão. 
- Organograma: "representação gráfica que, por refletir a estrutura organizacional de uma entidade produtora de arquivo, facilita o emprego do método estrutura" (Bellotto \& Camargo, 1996, p.57).

- Políticas e normas: são definidas pela alta direção, são políticas que regulamentam a atuação e o funcionamento da instituição e de quem faz parte dela.

- Relatório anual: "exposição de ocorrências, fatos, despesas, transações ou atividades realizadas por autoridade com a finalidade de prestar conta de seus atos à autoridade superior" (Bellotto, 2002, p.85).

- Relatórios gerenciais: esse tipo de documento é utilizado geralmente para avaliar o desempenho da instituição em diversas áreas. Trata-se, portanto, de documentos não oficiais.

Outra categoria de documentos produzidos pelas organizações são os documentos de reunião, cujo conteúdo apresenta as decisões e deliberações que foram tomadas em reuniões de diferentes naturezas e com distintos objetivos:

- Edital de convocação: tem a função de convocar os interessados a participar de determinada reunião ou evento que deva comparecer.

- Ata: "registro resumido das ocorrências de uma reunião, assembleia ou sessão, assim como das decisões tomadas por seus membros" (Bellotto, 2002, p.85). As atas são subdivididas em duas categorias: as atas de assembleia e as atas de reunião. As atas de assembleia dizem respeito a decisões tomadas em assembleias, portanto são de caráter soberano, pois não cabe questionamento. As atas de reunião "resumem deliberações de temas em diversos níveis hierárquicos, podendo ter ou não validade jurídica” (Pazin, 2005, p.19).

- Resoluções: registram uma decisão ou uma ordem na sua própria área de atuação.

Os documentos de gestão de recursos humanos dizem respeito às atividades da administração de pessoal, saúde e segurança do traba- 
lho e treinamento e desenvolvimento de pessoas (Pazin, 2005, p.19). Os documentos referentes às atividades de administração de pessoal são compostos por:

- Convenção coletiva de trabalho: "é a convenção coletiva de cada categoria profissional que rege as relações entre empregadores e empregados, no âmbito das questões específicas daquela atividade" (Pazin, 2005, p.19).

Os funcionários possuem um registro individual que é composto pelos seguintes documentos:

- Livro ou ficha de registro de empregado: registra os dados referentes ao contrato de trabalho e à evolução do funcionário.

- Prontuários: reunião de todos os documentos que relatam o desempenho de cada funcionário durante sua permanência na instituição, desde sua contratação até seu desligamento.

- Processos trabalhistas: contêm diversos tipos de documentos, e que, recebendo informações, pareceres e despachos, tramitam até que se cumpra o ato administrativo que gerou a sua criação. Geralmente são arquivados junto aos prontuários dos funcionários.

Os documentos de controle e pagamento são constituídos por:

- Folha, cartão ou livro de ponto: utilizado como meio de controle de entrada e saída dos funcionários.

- Folha de pagamento: registra as informações dos valores de salários pagos aos funcionários.

- Demonstrativos e recibos de pagamentos: "para cada tipo de pagamento haverá um demonstrativo com dados similares à folha de pagamento individual por funcionário, que deverá ser assinado para ter validade" (Pazin, 2005, p.20).

- Avisos de férias e recibos de férias: registram o período de férias de cada funcionário. É arquivado juntamente ao prontuário. 
Os documentos de recolhimentos de encargos e tributos são constituídos pelas "guias de recolhimentos" de todos os tipos de impostos e pelo "livro de inspeção do trabalho", que registra as ações realizadas durante a fiscalização do Fisco.

A área de saúde e segurança do trabalho registra as atividades ligadas à saúde, e a segurança do trabalhador é composta pelos documentos:

- Contrato de PCNSO (Programa de Controle Médico e Saúde Ocupacional NR-7): determina o acompanhamento médico dos trabalhadores por médico do trabalho, a partir do momento da admissão.

- Laudo de PPRA (Programa de Prevenção de Riscos Ambientais NR9): analisa os riscos ambientais à saúde do trabalhador, como ruído, iluminação etc.

- Mapa de avaliação de riscos: contém todos os riscos à saúde do trabalhador e determina ações de prevenção.

- Prontuário médico: contém o histórico clínico do funcionário e todos os exames realizados durante o tempo de permanência do funcionário na empresa.

- Livro de atas da CIPA (Comissão Interna de Prevenção de Acidentes NR-5): mensalmente esta comissão se reúne para discutir os acidentes ocorridos e encontrar soluções para que não voltem a ocorrer novamente.

- CAT (Comunicado de acidente de trabalho): deve ser apresentado em cada ocorrência de acidente de trabalho.

- Mapa de avaliação de acidentes de trabalho: a cada ocorrência de acidente é necessário analisar as condições do acidente, sugerindo ações para soluções dos problemas.

Finalizando, os documentos produzidos pela área de recursos humanos, mais especificamente os de treinamento e desenvolvimento de pessoas, são documentos relacionados ao "processo de seleção de pessoas para contratação, realização de treinamentos específicos e desenvolvimento de formas de avaliação do desempenho dos funcionários" (Pazin, 2005, p.23). Entre eles destacam-se: 
- Plano de cargos e salários: estabelece a relação entre o perfil de funções e salários compatíveis. É também o norteador do plano de carreira.

- Descrição de cargos: "tipo de relatório que contém o perfil de cada função existente na instituição” (Pazin, 2005, p.23).

- Programa de integração de novos funcionários: colabora com os novos funcionários a se integrarem à cultura da organização.

- Relatório de avaliação de desempenho: formulários aplicados periodicamente aos funcionários e gerentes. "Exposição de ocorrências, fatos, despesas, transações ou atividades realizadas por autoridade com a finalidade de prestar conta de seus atos à autoridade superior" (Bellotto, 2002, p.85).

- Programa de treinamento: planejamento dos cursos que serão oferecidos aos funcionários da instituição.

- Lista de presença: documento de controle de participação em treinamentos e cursos.

Outra categoria importante dos documentos produzidos pelas organizações são os documentos de comunicação e marketing, entre os principais podem-se destacar:

- Comunicados e circulares: são utilizados para comunicações administrativas e encontram-se em todas as áreas da instituição. São normalmente enviados a grupos ou pessoas com a finalidade de comunicar ou informar sobre algo.

- Plano de comunicação: faz parte geralmente do planejamento estratégico da instituição.

- Boletim interno ou jornal interno: meio utilizado para comunicação entre a instituição e os funcionários.

- Projetos de comunicação visual: referem-se principalmente à criação de logomarcas, placas de sinalização, formatos de apresentação de materiais para divulgação etc.

- Manual de utilização de marca: utilizado normalmente por grandes organizações que possuem contrato com empresas de publicidade. 
- Dossiês de eventos: "material usado para a realização de eventos, incluindo planejamento, cotações e orçamentos de fornecedores, correspondência, programação e relatório final" (Pazin, 2005, p.25).

- Dossiês de projetos de comunicação: contêm todos os documentos relativos ao desenvolvimento de projetos.

- Folders institucionais ou promocionais: têm a função de divulgar a própria instituição ou evento que a mesma esteja desenvolvendo.

- Folhetos de divulgação: apresentam abrangência temática maior que o folder, por esta razão, divulgam programas educacionais e também projetos.

- Plano de marketing: voltado principalmente às estratégias de inserção de novos produtos no mercado.

- Estudo de mercado: realizado com o intuito de "conhecer as características de determinada parcela de consumidores, com o objetivo de analisar a criação de novos produtos e as melhores estratégias de divulgação" (Pazin, 2005, p.26).

- Projeto de campanha publicitária: desenvolvido com a finalidade de inserção de um novo produto no mercado.

- Anúncio publicitário: "comunica ao público as qualidades de um produto ou serviço e os benefícios oferecidos aos consumidores, é a materialização da campanha publicitária” (Pazin, 2005, p.26).

- Brinde: registra as estratégias promocionais desenvolvidas pela instituição.

Os documentos administrativos formam outra categoria de documentos produzidos. São divididos em três áreas de atuação: área de administração de vendas/comercial, área de logística e área de compras/ suprimentos. Deve-se destacar que atualmente a maioria desses documentos é gerada e armazenada em meio eletrônico.

A área de vendas/comercial apresenta as seguintes tipologias:

- Planejamento comercial: "desenvolvimento de estratégias de abordagem aos clientes, com a finalidade de oferecer produtos aos compradores" (Pazin, 2005, p.27). 
- Catálogo de clientes: contém todos os dados dos clientes, normalmente encontra-se em meio eletrônico.

- Pedidos de produtos: formulários contendo todos os pedidos de clientes.

- Ordens de faturamento: "formulários onde são registrados os dados dos clientes e os produtos solicitados".

A área de logística tem a função de controlar a recepção, armazenamento e distribuição de materiais ou produtos e abrange as seguintes tipologias:

- Controle de entrada e saída de pessoas e veículos.

- Controle de manutenção de veículos de frota.

- Controle de expedição de produtos (Pazin, 2005, p.28).

Finalizando essa categoria, tem-se a área de compras/suprimentos, que é responsável pela aquisição de bens, produtos e serviços para todos os setores da instituição:

- Catálogo de fornecedores.

- Cotação de preços: tipo de planilha que contém os dados da pesquisa dos preços de produtos.

- Ordem de compra: autorização de aquisição de bens e produtos.

- Controle de estoque de almoxarifado: registra entrada e saída de matérias e a necessidade de reposição.

- Certificado de garantia de equipamentos (Pazin, 2005, p.28).

A sétima categoria diz respeito aos documentos financeiros; esses têm a função de registrar a atividade de controle orçamentário da organização.

- Orçamento: planejamento de gastos num dado período, geralmente anualmente.

- Extrato bancário.

- Relatório ou extrato de contas (financeiras). 
- Borderô de depósito bancário: relação de documentos para depósito.

- Relatório de conciliação bancária: "relatório para conferência dos lançamentos bancários, comparando-os com os lançamentos contábeis" (Pazin, 2005, p.29).

- Relatório de resultados.

Os documentos contábeis e fiscais, categoria que reúne todos os documentos relativos à escrituração comercial das atividades da instituição, são divididos em:

Normas e procedimentos:

- Relatórios e pareceres de auditoria: registra as avaliações realizadas pelas auditorias.

- Plano de contas (plano contábil): " relação contendo os códigos utilizados para classificação dos lançamentos contábeis” (Pazin, 2005, p.30).

Lançamentos contábeis:

- Nota fiscal de venda/prestação de serviços: documento de caráter fiscal que regulariza a venda de produtos e serviços. "Relação numerada na qual se especificam as mercadorias vendidas, indicando-se os preços unitários e o total, que obrigatoriamente as acompanha na entrega ao comprador" (Bellotto, 2002, p.76).

- Nota fiscal de aquisição de materiais, serviços e equipamentos: recebida na aquisição de bens e serviços.

- Fatura: contém tanto a oficialização da compra e venda como também a relação dos materiais envolvidos na operação.

- Recibos de pagamento: dizem respeito aos documentos contabilizados.

- DARF - Documento de Arrecadação e Recolhimento Federais.

- GIA - Guia de Informação e Apuração do ICMS.

Obrigações acessórias:

- DCTF - Declaração de Créditos e Débitos de Tributos Federais. 
- DIPJ - Declaração de Informações Econômicas e Fiscais da Pessoa Jurídica.

- DACON - Declaração Anual de Contribuições Sociais.

Registros de escrituração fiscal e comercial:

- Diário geral: livro comercial onde se registram em ordem cronológica todas as operações ativas e passivas dos fatos, e também o resumo do balanço.

- Balanço: "registro contábil resumido do valor do ativo, do passivo e do capital ou patrimônio líquido de uma entidade jurídica" (Pazin, 2005, p.31).

- Livros fiscais: "são aqueles de escrituração contábil que cumprem a finalidade de registrar fatos patrimoniais sujeitos à fiscalização tributária, seja federal, estadual ou municipal" (Pazin, 2005, p.31).

Documentos auxiliares: são relatórios que auxiliam na realização da contabilidade:

- Diário auxiliar: registra as movimentações contábeis diárias.

- Diário de contas-correntes: contém a escrituração dos débitos e créditos em cada conta contábil da instituição.

- Balancete de verificação: "balanço parcial da escrituração, realizado em períodos curtos para avaliação da situação das contas" (Pazin, 2005, p.32).

Os documentos jurídicos fazem parte de outra categoria das tipologias documentais produzidas e são produtos dos atos lícitos realizados pela organização, com a finalidade de adquirir, transferir, resguardar, modificar ou extinguir direitos:

- Procuração: "instrumento pelo qual uma pessoa recebe de outras poderes para, em nome delas, praticar atos ou administrar bens" (Bellotto, 2002, p.81). 
- Parecer jurídico: julgamento técnico expedido por especialista sobre determinado assunto, para fins de tomada de decisão.

- Autos de ação ou processo: registro escrito e autenticado de processo.

- Licitação: processo que contém os dados de formulação de preço, apresentação de proponentes e aprovação da melhor oferta.

Também fazem parte dessa categoria os documentos de caráter especial como: os títulos de propriedade intelectual, os contratos e os títulos de propriedade de bens móveis e imóveis.

Títulos de propriedade intelectual:

- Processo de registro de propriedade intelectual: cada marca ou patente para ter validade deve ser registrada no INPI (Instituto Nacional de Propriedade Intelectual). Este processo tem que ser desenvolvido por advogados e especialistas no assunto.

- Certificação de registro de marca: documento oficial que permite a utilização exclusiva de determinado desenho ou nome por instituição por um período determinado.

- Certificado de registro de patente: concessão de produção de direito sobre a produção de determinado tipo de produto.

- Registro de direito autoral: registro sobre obras culturais.

Contratos podem ser entendidos como o "registro de acordo pelo qual duas ou mais pessoas físicas ou jurídicas estabelecem entre si algum(uns) direito(s) e/ou obrigação(ções)" (Bellotto, 2002, p.60):

- Apólice de seguros: formalização de contratos de seguro.

- Contrato de prestação de serviços.

- Contrato de compra e venda de imóveis.

- Contrato de empréstimo e financiamento: realizado normalmente por instituições financeiras.

- Contrato envolvendo direitos autorais. 
- Termo de confissão de dívida: "contrato em que o devedor aceita as condições do credor, para quitação de dívida anteriormente adquirida e não cumprida” (Pazin, 2005, p.33).

Títulos de propriedade de bens móveis e imóveis:

- Escritura de compra e venda de imóveis.

- Certificação de registro e licenciamento de veículos.

- Certificação de ação: "título de propriedade, negociável, representativo de fração do capital de uma sociedade anônima, comprobatório dos direitos e obrigações dos que pertencem a tais sociedades" (Pazin, 2005, p.34).

A última categoria mencionada por Pazin (2005, p.34) são os documentos técnicos, voltados para as atividades-fim das organizações. Esses são divididos em quatro grandes grupos: desenvolvimento/projetos; produção; gestão e controle de qualidade; e atendimento a órgãos governamentais.

Área de desenvolvimento/projetos, voltada à criação de novos produtos e desenvolvimento de projetos específicos:

- Projeto de produtos: registro de todas as etapas, características de um projeto, geralmente apresenta-se em forma de dossiê.

- Desenho técnico.

Área de produção - documentos administrativos referentes ao processo produtivo:

- Controle de produção: conjunto de documentos relativos à administração da produção diária ou mensal, nas áreas produtivas da instituição.

- Relatórios de desenvolvimento de projetos/produtos: relatórios de resultados da implantação de projetos desenvolvidos pela empresa.

Área de gestão e controle de qualidade - responsável pela avaliação dos resultados obtidos na produção: 
- Manual de normas e procedimentos técnicos: produzido pela instituição para a realização das atividades tanto internas quanto externas.

- Relatórios de ensaio: relatórios de testes realizados para comprovar a qualidade dos produtos.

- Relatório de controle de qualidade: contém os resultados das atividades de controle de qualidade dos produtos.

É relevante dizer que o estudo realizado pela autora é de extrema importância, pois contempla todos os setores da organização, bem como mapeia os documentos produzidos e, ainda, os fluxos informacionais de cada departamento. Esses documentos contêm as informações de caráter orgânico, pois foram produzidos em decorrência da realização das atividades da organização e também refletem sua estrutura administrativa.

\section{Considerações finais}

Por meio das discussões realizadas fica evidente a interface entre a informação orgânica e a gestão documental. $O$ processo da gestão compreende o cumprimento de todas as fases do documento: corrente, intermediária e permanente. Portanto, garante o efetivo controle do documento desde sua produção até sua destinação final: eliminação ou guarda permanente, permitindo a rápida localização e acesso às informações.

Destaca-se a fase da produção documental em que a relação torna-se mais explícita, pois é o momento da produção da informação dentro do contexto do organismo. Essa fase compreende, ainda, o estudo de identificação dos documentos produzidos; entende-se aqui informação orgânica, pela instituição no exercício de suas funções, e também o contexto no qual foram produzidos (função, subfunção e atividade), ou seja, esse estudo permite a identificação e o mapeamento de quais são as informações de caráter orgânico, tornando-se fundamental para que se reconheçam dentro da organização quais 
são os produtores desse tipo de informação e assim monitorá-los em busca de informações orgânicas de características estratégicas. Isso porque os documentos alcançam uma grande dimensão, pois refletem um conteúdo constituído por uma estrutura e também embutido de significados em função do contexto no qual foi gerado, transmitido ou conservado.

Após o levantamento das tipologias produzidas pelas instituições em todos os setores, pode-se apontar a grande variedade de informações orgânicas que a empresa produz diariamente. Essas informações gerenciadas de forma adequada poderão se reverter de diversas maneiras para a organização, tanto na forma de racionalização de processos e procedimentos organizacionais como em vantagens competitivas.

Muitas vezes a estrutura organizacional atrapalha a boa circulação dos documentos nos diferentes setores, o que gera dificuldades na disseminação da informação. A partir da constatação desse fato, a gestão melhora a tramitação dos fluxos documentais, gerenciamento de maneira integrada, ou seja, incorporando todos os setores presentes, para que a informação chegue satisfatoriamente a todos os sujeitos envolvidos.

\section{Referências}

BELLOTTO, H. L. Como fazer análise diplomática e análise tipológica de documentos de arquivo. São Paulo, 2002. 120p. (Projeto Como Fazer, 8).

BELlOTTO, H. L.; CAMARGO, A. M. de A. (Coord.) Dicionário de terminologia arquivística. São Paulo: AAB-SP/ Secretaria de Estado de Cultura, 1996. 142p.

BERNARDES, I. P. (Coord.) Gestão documental aplicada. São Paulo: Arquivo Público do Estado de São Paulo, 2008. 54p.

BRASIL. Arquivo Nacional. Dicionário brasileiro de terminologia arquivística. Rio de Janeiro: Arquivo Nacional, 2005. 232p. (Publicações Técnicas, $n^{\circ} 51$ ) 
CARVALHO, E. L. de; LONGO, R. M. J. Informação orgânica: recurso estratégico para tomada de decisão pelos membros do Conselho de Administração da UEL. Informação E Informação, Londrina, v.7, n.2, p.113-33, jul./dez. 2002. Disponível em: <http:// www2.uel.br/revistas/informacao/viewarticle.php?id=125>. Acesso em: 10 jun. 2007.

DAVENPORT, T. H.; PRUSAK, L. Ecologia da informação: por que só a tecnologia não basta para o sucesso na era da informação. São Paulo: Futura, 1998. 316p.

FREITAS, H.; KLADIS, C. M. Da informação à política informacional das organizações: um quadro conceitual. RAP, São Paulo, v.29, n.3, p.73-86, jun./set. 1995. Disponível em: <http:// www.ea.ufrgs.br/professores/hfreitas/files/artigos/1995/ 1995_026_RAP.pdf>. Acesso em: 23 abr. 2008.

FONSECA, M. O. K. A arquivologia e a ciência da informação. Rio de Janeiro: Editora FGV, 2005. 124p.

ILHARCO, F. Filosofia da informação: uma introdução à informação como fundação da acção, da comunicação e da decisão. Lisboa: Universidade Católica, 2003. 207p.

INDOLFO, A. C. Gestão de documentos: uma renovação epistemológica no universo da arquivologia. Arquivística.net, Rio de janeiro, v.3, n.2, p.28-60, jul./dez. 2007

LIRA, W. S. et al. A busca e o uso da informação nas organizações. Perspectivas em ciência da informação, Belo Horizonte, v.13, n.1, jan./ abr. 2008. Disponível em: <http://www.scielo.br/scielo.php? script $=$ sci_arttext $\&$ pid $=\mathrm{S} 141399362008000100011 \& \operatorname{lng}=$ es\&nrm=isso >. Acesso em: 10 jun. 2007.

LOPES, L. C. A informação e os arquivos: teorias e práticas. Niterói: EDUFF; São Carlos: EDUFSCar, 1996. 142p.

LOUSADA, M.; VALENTIM, M. L. P. Informação orgânica como insumo do processo decisório empresarial. In:VALENTIM, M. L. P. (Org.) Gestão da informação e do conhecimento no âmbito da ciência da informação. São Paulo: Polis: Cultura Acadêmica, 2008. 268p.

MCGARRY, K. O contexto dinâmico da informação: uma análise introdutória. Brasília: Briquet de Lemos, 1999. 206p.

MIRANDA, R. C. da R. O uso da informação na formulação de ações estratégicas pelas empresas. Ciência da informação, Brasília, v.3, n.28, 
p.286-92, set./dez. 1999. Disponível em: <http://www.scielo.br/ pdf/ci/v28n3/v28n3a6.pdf>. Acesso em: 10 jun. 2007.

MORENO, N. A. A informação arquivística e o processo de tomada de decisão. Informação Ė Sociedade: Estudos, João Pessoa, v.17, n.1, p.9-19, jan./abr. 2007. Disponível em: <http://www.scielo.br/ scielo.php?pid=S0100->. Acesso em: 10 ago. 2007.

PAZIN, M. Arquivos de empresas: tipologia documental. São Paulo: Associação dos Arquivistas de São Paulo, 2005. 39p.

PONJUÁN DANTE, G. Gestión de información: dimensiones e implementación para el éxito organizacional. Rosário: Nuevo Parhadigma, 2004. 208p.

RHOADS, J. B. La función de la gestión de documentos y archivos en los sistemas nacionales de información: un estudio del RAMP. Paris: Unesco, 1989.

SORDI, J. O. de. Administração da informação: fundamentos e práticas para uma nova gestão do conhecimento. São Paulo: Saraiva, 2008. 185p. 


\section{SOBRE OS AUTORES}

André Luís Onório Coneglian - Doutorando do Programa de PósGraduação em Ciência da Informação da Universidade Estadual Paulista (Unesp/Marília). Mestre pelo Programa de Pós-Graduação em Ciência da Informação pela Universidade Estadual Paulista (Unesp/Marília). Licenciado em Pedagogia com habilitação em Deficiência Auditiva pela Universidade Estadual Paulista (Unesp/ Marília). Membro do Grupo de Pesquisa "Comportamento e competência informacionais".

Bárbara Fadel - Doutora em História Social pela Faculdade de Filosofia, Letras e Ciências Humanas da Universidade de São Paulo (USP). Mestre em História da América Latina pelo Instituto de História, Direito e Serviço Social da Unesp. Docente do Programa de Pós-Graduação em Ciência da Informação. Docente do Departamento de Administração e Coordenadora do "Centro de Documentação e Memória” do Centro Universitário Uni-Facef. Membro do Grupo de Pesquisa "Informação, conhecimento e inteligência organizacional".

Camila Araújo dos Santos - Mestranda do Programa de Ciência da Informação da Universidade Estadual Paulista (Unesp/Marília). 
Bacharel em Biblioteconomia pela Universidade Estadual Paulista (Unesp/Marília). Membro do Grupo de Pesquisa "Comportamento e competência informacionais".

Carlos Cândido de Almeida - Doutor em Ciência da Informação pela Universidade Estadual Paulista (Unesp/Marília). Mestre em Ciência da Informação pela Universidade Federal de Santa Catarina (UFSC). Graduado em Biblioteconomia pela Universidade Estadual de Londrina (UEL).

Cássia Regina Bassan de Moraes - Doutoranda do Programa de Pós-Graduação em Ciência da Informação da Universidade Estadual Paulista (Unesp/Marília). Mestre pelo Programa de Pós- Graduação em Ciência da Informação da Universidade Estadual Paulista (Unesp/Marília). Especialista em Administração de Recursos Humanos pela Fundação Armando Álvares Penteado (Faap/São Paulo). Psicóloga pela Universidade Estadual Paulista (Unesp/Assis). Professora Associada I da Faculdade de Tecnologia (Fatec/Garça). Coordenadora do Curso de Tecnologia em Gestão Empresarial da Faculdade de Tecnologia (Fatec/Garça). Membro do Grupo de Pesquisa "Informação, conhecimento e inteligência organizacional".

Cíntia Gomes Pacheco - Mestranda em Ciência da Informação pela Universidade Estadual Paulista (Unesp/Marília). Bacharel em Biblioteconomia pela Universidade Estadual Paulista (Unesp/ Marília). Membro do Grupo de Pesquisa "Informação, conhecimento e inteligência organizacional".

Elaine Cristina Lopes - Doutoranda do Programa de Pós-Graduação em Ciência da Informação da Universidade Estadual Paulista (Unesp/Marília). Mestre em Ciência da Informação pelo Programa de Pós-Graduação em Ciência da Informação da Universidade Estadual Paulista (Unesp/Marília). Especialista em Controladoria e Finanças e bacharel em Administração de Empresas. Membro do 
Grupo de Pesquisa "Informação, conhecimento e inteligência organizacional".

Helen de Castro Silva Casarin - Doutora em Estudos Literários pela Universidade Estadual Paulista (Unesp/Araraquara). Mestre em Ensino na Educação Brasileira pela Universidade Estadual Paulista (Unesp/Marília). Graduada em Biblioteconomia pela Universidade Estadual Paulista (Unesp/Marília). Atualmente é professor-assistente-doutora da Universidade Estadual Paulista (Unesp/Marília).

José Carlos Abbud Grácio - Doutorando do Programa de Pós-Graduação em Ciência da Informação da Universidade Estadual Paulista (Unesp/Marília). Mestre pelo Programa de Pós-Graduação em Ciência da Informação pela Universidade Estadual Paulista (Unesp/Marília). Bacharel em Ciência da Computação pela Universidade Estadual de Campinas (Unicamp/Campinas). Membro do Grupo de Pesquisa "Informação, conhecimento e inteligência organizacional".

Letícia Gorri Molina - Doutoranda do Programa de Ciência da Informação da Universidade Estadual Paulista (Unesp/Marília). Mestre pelo Programa de Pós-Graduação em Ciência da Informação pela Universidade Estadual Paulista (Unesp/Marília). Graduada em Biblioteconomia e em Psicologia pela Universidade Estadual de Londrina (UEL). Atualmente é docente colaboradora do Departamento de Ciência da Informação da UEL.

Luana Maia Woida - Doutoranda do Programa de Ciência da Informação da Universidade Estadual Paulista (Unesp/Marília). Mestre pelo Programa de Pós-Graduação em Ciência da Informação pela Universidade Estadual Paulista (Unesp/Marília). Bacharel em Administração pela Universidade Estadual de Londrina (UEL). Docente substituta em nível de graduação da Fundação Universidade Federal de Rio Grande (Furg-RS). Membro do Grupo de Pesquisa "Informação, conhecimento e inteligência organizacional". 
Luciane de Fátima Beckman Cavalcante-Doutoranda do Programa de Ciência da Informação da Universidade Estadual Paulista (Unesp/Marília). Mestre pelo Programa de Pós-Graduação em Ciência da Informação pela Universidade Estadual Paulista(Unesp/ Marília). Bacharel em Biblioteconomia pela Universidade Estadual Paulista (Unesp/Marília). Membro do Grupo de Pesquisa "Informação, conhecimento e inteligência organizacional”.

Mariana Lousada - Mestranda do Programa de Pós-Graduação em Ciência da Informação da Universidade Estadual Paulista (Unesp/ Marília). Bacharel em Arquivologia pela Universidade Estadual Paulista (Unesp/Marília). Membro do Grupo de Pesquisa "Informação, conhecimento e inteligência organizacional"

Marinês Santana Justo Smith - Doutoranda do Programa de PósGraduação em Ciência da Informação da Universidade Estadual Paulista (Unesp/Marília). Mestre em Administração - Área de Concentração Gestão Empresarial pelo Centro Universitário de Franca. Bacharel em Processamento de Dados pela Universidade de Franca. Bacharel em Ciências Contábeis pelo Uni-Facef. Docente titular de Graduação e Pós-Graduação Lato Sensu no Centro Universitário de Franca - Uni-Facef (autarquia municipal). Membro do Grupo de Pesquisa "Informação, conhecimento e inteligência organizacional” e do Grupo de Pesquisa "GEDE - Grupo de Estudos de Desenvolvimento" - Uni-Facef.

Marli Vítor da Silva-Mestranda do Programa de Ciência da Informação da Universidade Estadual Paulista (Unesp/Marília). Bacharel em Biblioteconomia pela Universidade Estadual Paulista (Unesp/Marília). Membro do Grupo de Pesquisa "Comportamento e competência informacionais".

Marta Lígia Pomim Valentim - Livre-docente em "Informação, conhecimento e inteligência organizacional” pela Universidade Estadual Paulista (Unesp/Marília). Doutora em Ciências da Comuni- 
cação pela Escola de Comunicação e Arte da Universidade de São Paulo (ECA/USP). Mestre pela PUC-Campinas. Docente de Graduação e Pós-Graduação da Universidade Estadual Paulista(Unesp/ Marília). Líder do Grupo de Pesquisa "Informação, conhecimento e inteligência organizacional”.

Oswaldo Francisco de Almeida Júnior - Doutor e mestre em Ciências da Comunicação pela Escola de Comunicação e Arte da Universidade de São Paulo (ECA/USP). Bacharel em Biblioteconomia e Documentação pela Fesp/SP. Professor associado do Departamento de Ciência da Informação da Universidade Estadual de Londrina (UEL). Docente do mestrado profissional em Gestão da Informação da UEL. Docente do Programa de Pós-Graduação em Ciência da Informação da Unesp/Marília.

Regina Célia Baptista Belluzzo - Pós-Doutorada em Gestão Escolar pela Universidade Estadual Paulista (Unesp/Araraquara). Doutora e mestre em Ciências da Comunicação pela Universidade de São Paulo (USP). Bacharel em Biblioteconomia e Documentação pela Escola de Biblioteconomia e Documentação de São Carlos. Bacharel em Direito pela Faculdade de Direito de São Carlos.

Regis Garcia - Executivo de empresas. Professor universitário e de Pós-Graduação. Doutorando do Programa de Pós-Graduação em Ciência da Informação na Universidade Estadual Paulista (Unesp/ Marília). Mestre em Contabilidade e Finanças pela UFPR. Especialista em Contabilidade Gerencial e Societária pela Universidade de Londrina (UEL), e em Controladoria e Gestão Financeira pela Faccar. Graduado em Ciências Contábeis pela UEL.

Rodrigo Octávio Beton Matta - Doutorando do Programa de Ciência da Informação da Universidade Estadual Paulista (Unesp/ Marília). Mestre pelo Programa de Pós-Graduação em Ciência da Informação pela Universidade de Brasília (UnB). Bacharel em Administração de Empresas pela Universidade de Brasília (UnB). 
Membro do Grupo de Pesquisa "Comportamento e competência informacionais".

Sueli Bortolin - Doutoranda do Programa de Pós-Graduação em Ciência da Informação da Universidade Estadual Paulista (Unesp/ Marília). Mestre pelo Programa de Pós-Graduação em Ciência da Informação pela Universidade Estadual Paulista (Unesp/Marília). Graduada em Biblioteconomia pela Universidade Estadual de Londrina (UEL). Docente do Departamento de Ciência da Informação da UEL.

Tamara de Souza Brandão Guaraldo - Doutoranda do Programa de Pós-Graduação em Ciência da Informação da Universidade Estadual Paulista (Unesp/Marília). Mestre pelo Programa de Pós-Graduação em Comunicação pela Universidade Estadual Paulista (Unesp/Bauru). Graduada em Jornalismo pela Unesp. Docente em cursos de Comunicação Social. 
SOBRE O LIVRO

Formato: $14 \times 21 \mathrm{~cm}$

Mancha: $23,7 \times 42,5$ paicas

Tipologia: Horley Old Style 10,5/14

Papel: Offset $75 \mathrm{~g} / \mathrm{m}^{2}$ (miolo)

Cartão Supremo $250 \mathrm{~g} / \mathrm{m}^{2}$ (capa)

$1^{\text {a }}$ edição: 2010

\section{EQUIPE DE REALIZAÇÃO}

Coordenação Geral

Marcos Keith Takahashi 


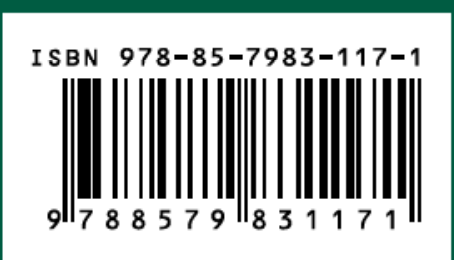

